Andrews University

Digital Commons @ Andrews University

\title{
The Nature of David's Kingship at Hebron: An Exegetical and Theological Study of 2 Samuel 2:1-5:5
}

Christian Vogel

Andrews University, vogel@andrews.edu

Follow this and additional works at: https://digitalcommons.andrews.edu/dissertations

Part of the Biblical Studies Commons

\section{Recommended Citation}

Vogel, Christian, "The Nature of David's Kingship at Hebron: An Exegetical and Theological Study of 2 Samuel 2:1-5:5" (2019). Dissertations. 1684.

https://digitalcommons.andrews.edu/dissertations/1684

https://dx.doi.org/10.32597/dissertations/1684

This Dissertation is brought to you for free and open access by the Graduate Research at Digital Commons @ Andrews University. It has been accepted for inclusion in Dissertations by an authorized administrator of Digital Commons@ Andrews University. For more information, please contact repository@andrews.edu. 


\begin{abstract}
THE NATURE OF DAVID'S KINGSHIP AT HEBRON: AN EXEGETICAL AND THEOLOGICAL STUDY OF 2 SAMUEL 2:1-5:5
\end{abstract}

by

Christian Vogel

Adviser: Richard M. Davidson 


\title{
ABSTRACT OF GRADUATE STUDENT RESEARCH
}

Dissertation

\author{
Andrews University
}

Seventh-day Adventist Theological Seminary

\section{Title: THE NATURE OF DAVID'S KINGSHIP AT HEBRON: AN EXEGETICAL AND THEOLOGICAL STUDY OF 2 SAMUEL 2:1-5:5}

Name of researcher: Christian Vogel

Name and degree of faculty adviser: Richard M. Davidson, Ph.D.

Date completed: June 2019

The account of David's reign at Hebron found in 2 Samuel 2:1-5:5 constitutes a somewhat neglected, yet crucial part of the David narrative, chronicling David's first years as king. This dissertation investigates these chapters by means of a close reading of the Hebrew text in order to gain a better understanding of the nature of David's kingship as it is presented in this literary unit.

The review of scholarly literature on 2 Samuel 2:1-5:5 conducted in Chapter 1 reveals that not much attention has been given to a careful and in-depth exegesis of this literary unit. Instead, most of the examined studies have focused on redactional and/or historical issues in order to demonstrate the pro-davidic ideology of the narrative. Though a few studies have examined 2 Samuel 2:1-5:5 from a literary perspective, none of them 
have dealt exclusively with this part of the David narrative or with the specific issue of the nature of David's kingship in this literary unit.

Chapters $2-4$ are therefore dedicated to a careful exegetical analysis of each of the six literary units within 2 Samuel 2:1-5:5. Particular attention is given to the literary features of the text such as its structure, keywords and phrases as well as intertextual connections to earlier parts of the David narrative and of the Old Testament in general. For each of the six literary units the implications concerning the nature of David's kingship that emerge from a close reading of the text are noted.

In Chapter 5 the results of the research are summarized. The exegetical analysis demonstrates that 2 Samuel 2:1 $-5: 5$ is a carefully crafted work of art throughout which the kingships of David and Ish-boshet/Abner are compared and contrasted. Based on the close reading of the passage, the following conclusions are drawn concerning the nature of David's kingship:

1. The legitimacy of David's kingship is affirmed. He is chosen by YHWH, recognized by Saul and the people, associated with the faithful Saul, qualified by his character, personality and experience as well as by the special title נָּגִ.

2. Foundational elements of David's kingship include divine guidance, obedience to YHWH's will and law, justice, unity, freedom of choice, respect and kindness toward others, concern for the people, humility and proper selfassessment, חִֶ? and repaying good with good, sorrow over evil, peace, strength and continuity. 
3. The purpose of David's kingship seems to be to enable a return to the Edenic model by finishing the conquest, saving Israel from its enemies and caring for YHWH's people and inheritance. 
Andrews University

Seventh-day Adventist Theological Seminary

THE NATURE OF DAVID'S KINGSHIP AT HEBRON: AN EXEGETICAL AND THEOLOGICAL STUDY OF 2 SAMUEL $2: 1-5: 5$

\author{
A Dissertation \\ Presented in Partial Fulfillment \\ of the Requirements for the Degree \\ Doctor of Philosophy
}

by

Christian Vogel

2019 
(C) Copyright by Christian Vogel 2019 All Rights Reserved 


\title{
THE NATURE OF DAVID'S KINGSHIP AT HEBRON: AN EXEGETICAL AND THEOLOGICAL STUDY OF 2 SAMUEL 2:1-5:5
}

\author{
A dissertation \\ presented in partial fulfillment \\ of the requirements for the degree \\ Doctor of Philosophy
}

by

Christian Vogel

APPROVAL BY THE COMMITTEE:

Faculty Adviser

Richard M. Davidson

J.N. Andrews Professor of Old Testament

Interpretation

Jacques B. Doukhan

Professor of Hebrew and Old Testament

Exegesis Emeritus

Jiri Moskala

Professor of Old Testament Exegesis and

Theology

Oliver Glanz

Associate Professor of Old Testament

Robert D. Bergen

Distinguished Professor of Old Testament

Emeritus

Hannibal-LaGrange University
Director, Ph.D./Th.D. Programs

Tom R. Shepherd

Dean, SDA Theological Seminary

Jiri Moskala
Date Approved 


\section{TABLE OF CONTESTS}

LIST OF ABBREVIATIONS ....................................................................... vii

\section{Chapters}

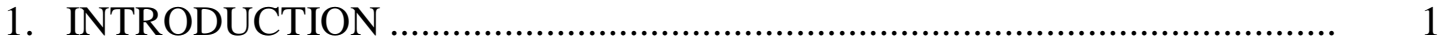

Background of the Problem.............................................................. 1

Statement of the Problem ...................................................................... 6

Statement of Purpose .......................................................................... 6

Justification of the Study ............................................................... 6

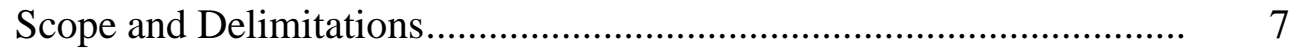

Methodology ......................................................................... 8

Review of Literature ................................................................. 9

Hans-Ulrich Nübel ................................................................ 9

Friedrich Mildenberger ......................................................... 11

Rolf A. Carlson ......................................................................... 14

Artur Weiser .................................................................. 16

Roger L. Ward .................................................................... 18

Jakob H. Grønbæk.......................................................... 22

David M. Gunn ..................................................................... 27

Niels P. Lemche ................................................................... 30

P. Kyle McCarter ................................................................ 33

James Vanderkam .............................................................. 35

Keith W. Whitelam ............................................................. 38

Terence J. Kleven ................................................................. 39

Jan Fokkelman ................................................................ 41

Steven L. McKenzie ................................................................. 43

Baruch Halpern ................................................................... 46

Klaus-Peter Adam ............................................................ 48

John Van Seters ......................................................................... 49

J. Randall Short .................................................................. 53

Cephas T.A. Tushima............................................................ 54

Summary ..................................................................... 58

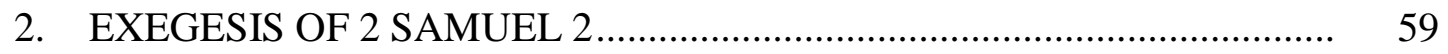

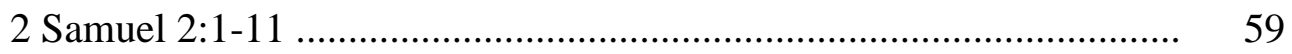

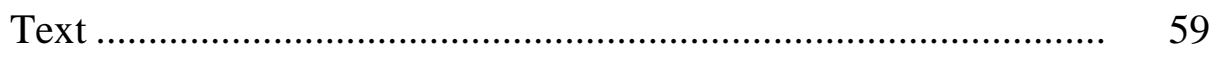

iii 


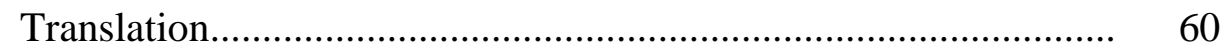

Delimitation .................................................................. 60

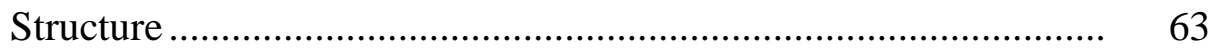

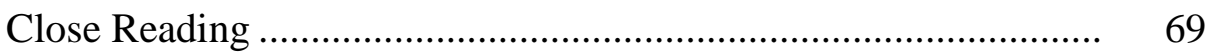

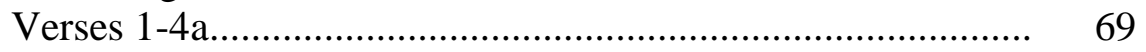

Verses 4b-7 .............................................................. 79

Verses 8-11 ................................................................. 90

Implications for the Nature of David's Kingship.......................... 102

The Legitimacy of David's Kingship ...................................... 102

Foundational elements of David's Kingship........................... 104

The Purpose of David's Kingship............................................ 107

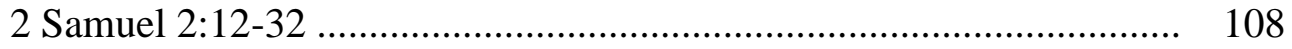

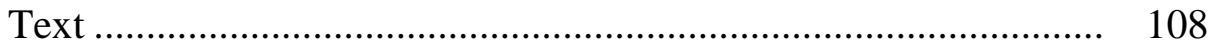

Translation............................................................................. 109

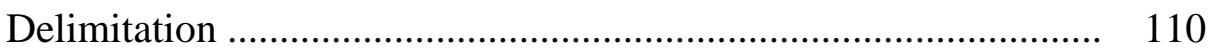

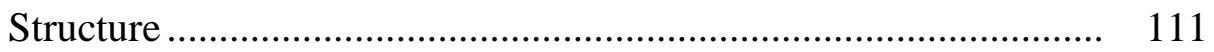

Close Reading ....................................................................... 115

Verses 12-13a............................................................... 115

Verses 13b-17 ......................................................... 118

Verses 18-24a..................................................................... 128

Verses 24b-28 ....................................................... 137

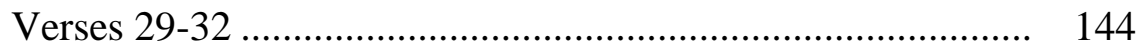

Implications for the Nature of David's Kingship.......................... 148

The Legitimacy of David's Kingship .................................... 149

Foundational elements of David's Kingship............................ 151

The Purpose of David's Kingship........................................... 153

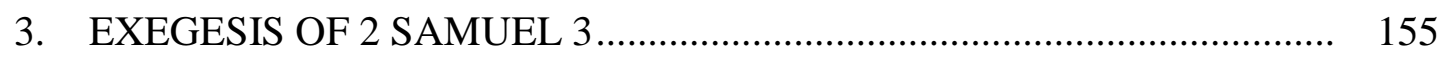

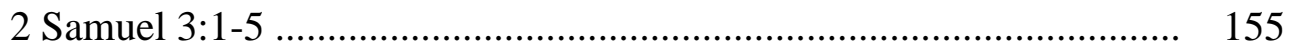

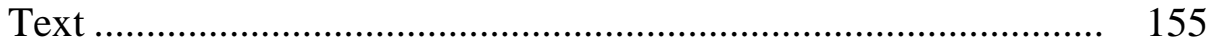

Translation.......................................................................... 155

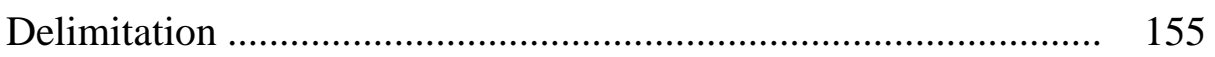

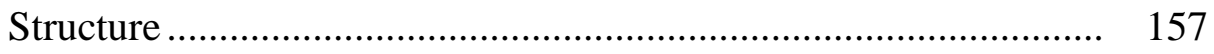

Close Reading ….................................................................. 162

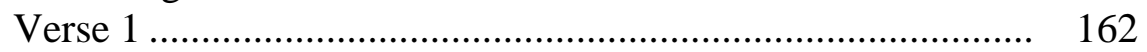

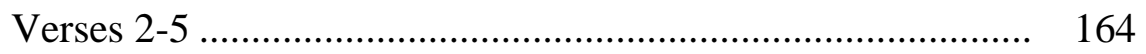

Implications for the Nature of David's Kingship......................... 170

The Legitimacy of David's Kingship ....................................... 170

Foundational Elements of David's Kingship ........................... 171

The Purpose of David's Kingship............................................. 173

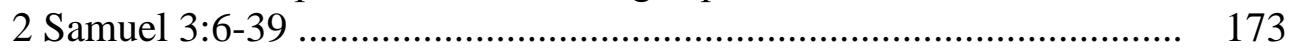

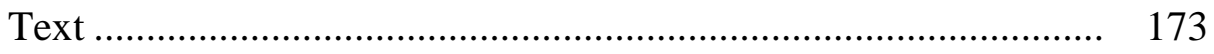

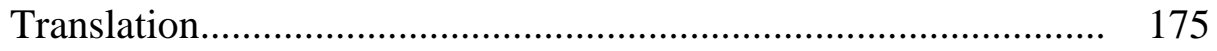

Delimitation ................................................................. 176 


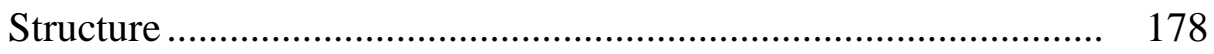

Close Reading ..................................................................... 184

Verses 6-11 ......................................................... 184

Verses 12-16 ............................................................... 197

Verses 17-19 ................................................................. 209

Verses 20-21 ............................................................ 215

Verses 22-27 .................................................................. 217

Verses 28-30 ............................................................. 227

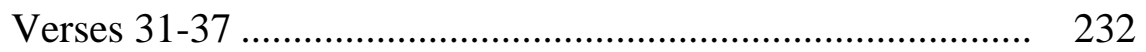

Verses 38-39 ............................................................ 240

Implications for the Nature of David's Kingship........................... 242

The Legitimacy of David's Kingship .................................... 243

Foundational Elements of David's Kingship ......................... 244

The Purpose of David's Kingship............................................ 249

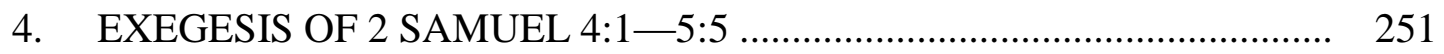

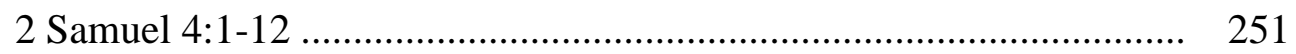

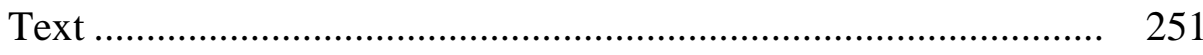

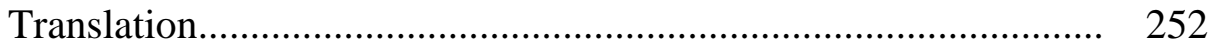

Delimitation ................................................................... 252

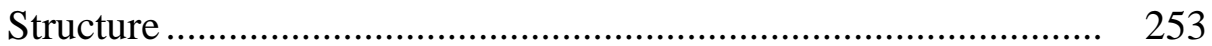

Close Reading …................................................................ 257

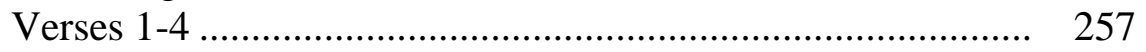

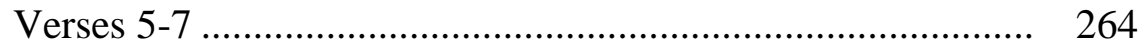

Verses 8-12 .............................................................. 269

Implications for the Nature of David's Kingship........................... 277

The Legitimacy of David's Kingship ..................................... 278

Foundational Elements of David's Kingship .......................... 278

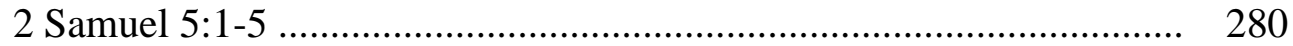

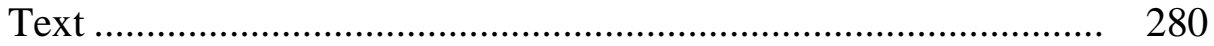

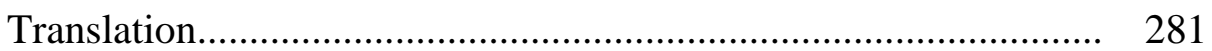

Delimitation ........................................................................ 281

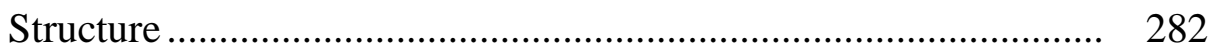

Close Reading …................................................................ 284

Verses 1-2 .......................................................... 284

Verse 3 …........................................................ 291

Verses 4-5 ..................................................................... 294

Implications for the Nature of David's Kingship............................ 296

The Legitimacy of David's Kingship ..................................... 296

Foundational Elements of David's kingship........................... 298

The Purpose of David's kingship.............................................. $\quad 300$

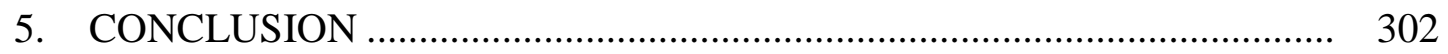

The Legitimacy of David's Kingship ................................................. 302 
Foundational elements of David's Kingship .................................... 305

The Purpose of David's Kingship ......................................................... 313

The Portrait of David............................................................................... 316

Perspectives ............................................................................. 319

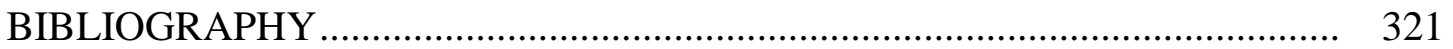




\section{LIST OF ABBREVIATIONS}

$\begin{array}{ll}\text { AB } & \text { Anchor Bible } \\ \text { ABD } & \text { Anchor Bible Dictionary } \\ \text { ApOTC } & \text { Apollos Old Testament Commentary } \\ \text { BBB } & \text { Bonner biblische Beiträge } \\ \text { BerO } & \text { Berit Olam } \\ \text { CBibC } & \text { Cornerstone Biblical Commentary } \\ \text { CPNIVC } & \text { The College Press NIV Commentary } \\ \text { FBC } & \text { Focus on the Bible Commentaries } \\ \text { FOTL } & \text { Forms of Old Testament Literature } \\ \text { IBC } & \text { Interpretation: A Bible Commentary for Teaching and Preaching } \\ \text { ISBE } & \text { International Standard Bible Encyclopedia } \\ \text { ITC } & \text { International Theological Commentary } \\ \text { NAC } & \text { New American Commentary } \\ \text { NIBCOT } & \text { New International Biblical Commentary on the Old Testament } \\ \text { NIDB } & \text { New Interpreter's Dictionary of the Bible } \\ \text { NIDOTTE } & \text { New International Dictionary of Old Testament Theology and } \\ \text { NIVAC } & \text { Niv Application Commentary } \\ \text { NBB } & \text { Neacon Bible Commentary } \\ & \end{array}$




$\begin{array}{ll}\text { OTL } & \text { Old Testament Library } \\ \text { SDAIBC } & \text { Seventh-Day Adventist International Bible Commentary } \\ \text { SHBC } & \text { Smyth \& Helwys Bible Commentary } \\ \text { TTC } & \text { Teach the Text Commentary } \\ \text { WBC } & \text { Word Biblical Commentary } \\ \text { WS } & \text { Zürcher Bibelkommentare }\end{array}$




\section{CHAPTER 1}

\section{INTRODUCTION}

\section{Background of the Problem}

The last few decades have witnessed a renewed interest in the biblical narratives. This development has in large part been due to an increased focus on the Bible as literature and the accompanying rise of modern literary criticism as an accepted method of interpretation within biblical studies in the latter part of the twentieth century. Disenchanted with the methods and results of historical criticism, an increasing number of scholars in the 1960s and 70s turned to literary approaches such as rhetorical criticism and structuralism to study biblical texts, in particular those belonging to the genre of narrative. ${ }^{1}$ Rather than dissecting texts into various sources and examining their prehistory and Sitz im Leben, these new approaches focused on the final form of texts, showing their intentional design, artistic beauty and intricately interconnected unity. Such insights were particularly revolutionary with regard to the biblical narratives, many of which had been viewed by the great majority of scholars as nothing more than rather primitive and haphazard conglomerations of different ancient oral traditions. Today such views are espoused much less frequently. Instead, there is now in many quarters of

\footnotetext{
${ }^{1}$ Peter D. Miscall, "Introduction to Narrative Literature," in The New Interpreter's Bible: Numbers-Samuel, ed. Leander E. Keck (Nashville, TN: Abingdon Press, 1998), 2:539-40.
} 
biblical scholarship a new appreciation of the biblical narratives as highly sophisticated

literary masterpieces, which in turn has resulted in a wealth of publications devoted to

their study. ${ }^{2}$

Among those biblical stories that have received the most attention in recent years

has been the David narrative found in 1 Sam 16-1 Kgs 2. Just within the last thirty years

numerous books, dissertations and theses have been written that deal with the whole

narrative or with some part of it. ${ }^{3}$ This is not surprising given the dramatic character of

many of the David stories as well as the prominence of the entire narrative within the

\footnotetext{
${ }^{2}$ See e.g. Robert Alter, The Art of Biblical Narrative (New York: Basic Books, 1981); Adele Berlin, Poetics and Interpretation of Biblical Narrative (Sheffield: Almond Press, 1983); Meir Sternberg, The Poetics of Biblical Narrative: Ideological Literature and the Drama of Reading (Bloomington, IN: Indiana University Press, 1987); Shimon Bar-Efrat, Narrative Art in the Bible (Sheffield: Sheffield Academic Press, 1989); Jan Fokkelman, Reading Biblical Narrative: An Introductory Guide (Louisville, KY: Westminster John Knox Press, 2000); Jerome Walsh, Old Testament Narrative: A Guide to Interpretation (Louisville, KY: Westminster John Knox Press, 2009).

${ }^{3}$ Notable recent studies include Timo Veijola, David: Gesammelte Studien zu den Davidüberlieferungen des Alten Testaments (Helsinki: Finnische Exegetische Gesellschaft, 1990); Jan Fokkelmann, Narrative Art and Poetry in the Books of Samuel: A Full Interpretation Based on Stylistic and Structural Analysis, 4 vols (Assen, Netherlands: Van Gorcum, 1981-1993); Terence J. Kleven, "Hebrew Style and Narrative Sequence in II Samuel I-VII" (PhD diss., Manchester University, 1990); Robert Polzin, David and the Deuteronomist: 2 Samuel (Bloomington, Ind.: Indiana University Press, 1993); Lyle M. Eslinger, House of God or House of David: The Rhetoric of 2 Samuel 7 (Sheffield: JSOT Press, 1994); K. L. Noll, The Faces of David (Sheffield: Sheffield Academic Press, 1997); Donald F. Murray, Divine Prerogative and Royal Pretension: Pragmatics, Poetics, and Polemics in a Narrative Sequence about David (2 Samuel 5.17-7.29) (Sheffield: Sheffield Academic Press, 1998); Martin J. Steussy, David: Biblical Portraits of Power (Columbia, SC: University of South Carolina Press, 1999); Keith Bodner, David Observed: A King in the Eyes of His Court (Sheffield: Sheffield Phoenix Press, 2005); Michael Eschelbach, Has Joab Foiled David?: A Literary Study of the Importance of Joab's Character in Relation to David (New York: Peter Lang, 2005); Klaus-Peter Adam, Saul und David in der Judäischen Geschichtsschreibung: Studien zu 1 Samuel 16 -2 Samuel 5 (Tübingen: Mohr Siebeck, 2007); Paul Borgman, David, Saul and God: Rediscovering an Ancient Story (Oxford: Oxford University Press, 2008); Uriah Kim, Identity and Loyalty in the David Story: A Postcolonial Reading (Sheffield: Sheffield Phoenix Press, 2008); Graeme A. Auld and Erik Eynikel, eds., For and Against David: Story and History in the Books of Samuel (Leuven; Walpole, MA: Peeters, 2010); Tod Linafelt, Claudia V. Camp and Timothy Beal, eds., The Fate of King David: The Past and Present of a Biblical Icon (New York: T\&T Clark, 2010); J. Randall Short, The Surprising Election and Confirmation of King David (Cambridge, MA: Harvard University Press, 2010); Cephas T.A. Tushima, The Fate of Saul's Progeny in the Reign of David (Eugene, OR: Pickwick, 2011).
} 
biblical canon. ${ }^{4}$ Particular attention has been given to the story of David and Bathsheba in 2 Sam $11,{ }^{5}$ to the concluding section of 2 Samuel comprising chapters $21-24,{ }^{6}$ as well as to the so-called Succession Narrative (SN) in 2 Sam $9-20$ and $1 \mathrm{Kgs} 1-2 .^{7}$

While many of the individual narratives and even larger sections of the David story have thus been studied quite extensively in recent years, other parts have received less attention. Among these somewhat neglected parts are the narratives dealing with David's reign in Hebron as king over Judah (2 Sam 2:1-5:5). Though these chapters have been dealt with on occasion in examinations of larger sections of 1-2 Samuel, ${ }^{8}$ no

\footnotetext{
${ }^{4}$ With the exception of Moses and Jesus, no other biblical character receives as much narrative space as David.

${ }^{5}$ Major studies include: Carolyn E. Finamor, "Perception and Being Perceived in 2 Samuel 11: A Narratological Approach" (M.A. thesis, Trinity Western University, 2007); Roy G. W. Bungay, "Narrative Structure and Character Development in 2 Samuel 11" (M.A. thesis, Memorial University of Newfoundland, 1996); George V.C. Arackal, "David's Fall and Redemption: A Study of 2 Samuel 10-12 as a unit of Biblical Narrative Literature" (ThD diss., Pontificia Universita Gregoriana, 1996); Carl Gary Staats, "Aspects of Negative Role Modeling in the David/Bathsheba Story and its Sequel" (PhD diss., New York University, 1989); Randall C. Bailey, "A Critical Investigation of 2 Samuel 10-12 and its Implications for the so-called Throne Succession Narrative" (PhD diss., Emory University, 1987).
}

${ }^{6}$ Major studies include: Daniel L. McNaughton, "A Comparative Analysis of Three Versions of 2 Samuel 21:1-14" (PhD diss., University of St. Michael's College, 2000); Arie Cohen, "David and the Gibeonites (2 Samuel 21:1-14)" (DHL diss., The Jewish Theological Seminary of America, 1998); Herbert H. Clement, "2 Samuel 21-24: Structure, Context and Meaning in the Samuel Conclusion" (PhD diss., Coventry University, 1995); William Yarchin, "The Warrior and the Shepherd: A Composition Analysis of 2 Samuel 21-24" (PhD diss., The Claremont Graduate School, 1993).

${ }^{7}$ Major studies include: Stefan Seiler, Die Geschichte von der Thronfolge Davids (2 Sam 9-20; 1 Kön 1-2): Untersuchungen zur Literarkritik (Berlin; New York: de Gruyter, 1998); Raymond P. Pennoyer, "Solomonic Apologetic: Text and Redaction in the Succession Narrative with Special Attention to the So-called 'Miscellanies' in 3 Reigns 2" (PhD diss., Johns Hopkins University, 1993); Mark W. Gregory, "Narrative Time in the Keret Epic and the Succession Narrative" (PhD diss., Southern Baptist Theological Seminary, 1988); Gillian Keys, "The So-Called Succession Narrative: A Reappraisal of Leonard Rost's Interpretation of II Samuel 9-20 and I Kings 1-2" (PhD diss., Queen's University of Belfast, 1988).

${ }^{8}$ See e.g., the studies by Fokkelman, Kleven, Polzin, Short and Tushima. In each case, 2 Sam 2:1-5:5 is not the primary focus but only one part in a larger work. The same goes for several earlier studies, done mostly in the 1950s and '60s in which this section is examined in the context of an investigation of the so-called History of David's Rise. These studies, which were in general conducted from a historical-critical perspective, include: Hans-Ulrich Nübel, Davids Aufstieg in der frühen Israelitischen 
major study has been devoted exclusively to this particular section or any of the chapters within it and only a handful of articles have been published. ${ }^{9}$ The relative inattention given to these stories - particularly from an exegetical and theological point of view - is somewhat surprising given the importance of this section for the whole David narrative. Not only do these chapters present a major turning point in the life of David and in the history of Israel, but they also chronicle the beginning of David's reign and therefore play a crucial role in understanding and assessing the nature of his kingship.

That David's kingship is a central theme in 2 Sam 2:1-5:5 is already indicated by the fact that the whole section is framed by references to David's anointing, first as king over Judah (2:4), then as king over all Israel (5:3). Further evidence for the prominence of this theme in these chapters is found in the frequent appearance of the keyword ${ }^{10}$ as well as in the fact that these chapters feature not just one but actually

Geschichtsschreibung (Diss., Friedrich-Wilhelms-Universität, 1959); Artur Weiser, "Die Legitimation des Königs David: Zur Eigenart und Entstehung der sogenannten Geschichte von David's Aufstieg," Vetus Testamentum 16 (1966): 325-54; Roger L. Ward, The Story of David's Rise: A Tradicio-Historical Study of I Samuel XVI 14-II Samuel V (PhD diss., Vanderbilt University, 1967) and Jakob H. Grønbæk, Die Geschichte vom Aufstieg Davids: (1 Sam 15-2 Sam. 5), Tradition und Komposition (Acta Theologica Danica; Copenhagen: Prostant Apud Munksgaard, 1971).

${ }^{9}$ Articles include: James T. Dennison, “Joab and Abner: Narrative Symmetries Sandwiching David: 2 Samuel 3:6-12, 17-39," Kerux 25 (2010): 27-37; Steven Holloway, "Distaff, Crutch or Chain Gang: The Curse of the House of Joab in 2 Samuel 3:29," Vetus Testamentum 37 (1987): 370-75; Scott Layton, “A Chain Gang in 2 Samuel 3:29: A Rejoinder," Vetus Testamentum 39 (1989): 81-86; James Vanderkam, "Davidic Complicity in the Deaths of Abner and Eshbaal: A Historic and Redactional Study," Journal of Biblical Literature 99 (1980): 521-539; Yael Shemesh, "Madua harag Yoab et Abner," Beit Mikra 173 (2003): 144-53; Keith Bodner, "Crime Scene Investigation: A Text-Critical Mystery and the Strange Death of Ishbosheth," Journal of Hebrew Scriptures 7 (2007): 2-18; Matitiahu Tsevat, "Ishbosheth and Congeners: The Names and their Study," Hebrew Union College Annual 46 (1975): 71-87; Diana Edelman, "The 'Ashurites' of Eshbaal's State (2 Sam 2:9)," Palestine Exploration Quarterly 117 (1985): 85-91.

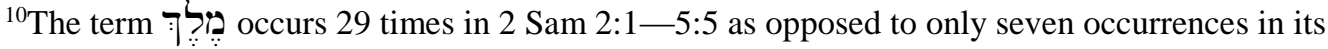
immediate context (zero in 2 Sam 1 and seven in 2 Sam 5:6-6:23)
} 
two reigns that appear to be compared and contrasted to each other, suggesting that it is the nature of these reigns and the difference between them that is a crucial issue in this part of the book.

While no substantial exploration of this subject has been attempted, some attention has been given to the closely related issue of how David is portrayed in 2 Sam 2:1-5:5. ${ }^{11}$ This topic has been of particular interest to those who view 2 Sam 2:1-5:5 as part of an apology designed to defend David against the charge that he ruthlessly grasped for power and was behind the murders of Abner and Ish-boshet. According to these scholars, the portrait of David in the apology is consistently positive as the author seeks to clear him of all possible charges, but the real David was very different. Lemche, for example, contends that David is a shrewd and cunning politician who is relentlessly pursuing his own agenda, ${ }^{12}$ Vanderkam claims that he "both desired and planned the death of Abner,"13 and Halpern goes as far as labeling him a "serial killer" who had his hand in the assassinations of Abner and Ish-boshet as well as of a number of other individuals in 2 Samuel. ${ }^{14}$ What is striking about these studies is that none of them support their claim that David is portrayed very positively throughout the text by a careful exegesis of the same. It thus remains unclear whether this claim is actually valid.

\footnotetext{
${ }^{11}$ See e.g. Baruch Halpern, David's Secret Demons: Messiah, Murderer, Traitor, King (Grand Rapids, MI: Eerdmans, 2001), 73-103 and Steven L. McKenzie, King David: A Biography (Oxford: Oxford University Press, 2000), 127.

${ }^{12}$ Niels P. Lemche, “David's Rise,” Journal for the Study of the Old Testament 10 (1978): 14-18.

${ }^{13}$ Vanderkam, "Davidic Complicity," 533.

${ }^{14}$ Halpern, David's Secret Demons, 73-103. See also McKenzie, King David, 127. Note that McKenzie titles his chapter on David's Reign as King of Judah “Assassin”.
} 
This also means that there is still a need for a careful exegetical and theological analysis of 2 Sam 2:1-5:5 which seeks to assess the portrayal of David and the nature of his reign as it is presented in this section from a textual basis.

Such an analysis is also warranted in light of the significance of this issue for a correct understanding of the larger David narrative. Since 2 Sam 2:1-5:5 features the beginning of David's reign these chapters are foundational for the subsequent parts of that reign and the view one takes regarding the nature of his reign in this section has implications for one's view of his kingship in general.

\section{Statement of the Problem}

Though a number of textual clues suggest that the nature of David's kingship is a significant issue in 2 Sam $2: 1-5: 5$, the topic has not been adequately explored in this section of the Samuel books. The closely related issue of how David is portrayed in 2 Sam 2:1-5:5 has also not been dealt with from a textual basis.

\section{Statement of Purpose}

The purpose of this study is to ascertain the nature of David's kingship as it is presented in 2 Sam 2:1-5:5.

\section{Justification of the Study}

As already indicated above such an analysis is justified for a number of reasons:

1. No major study has examined the central issue of the nature of David's reign in $2 \operatorname{Sam} 2: 1-5: 5$ 
2. Determining the precise nature of David's reign in 2 Sam 2:1-5:5 is vitally important since this section marks the beginning of that reign and is therefore foundational for a correct understanding of the subsequent presentation of David's kingship in the remainder of the David narrative.

3. A clarification of the nature of David's reign in this section would shed light on the biblical portrayal of David in general and may thus also provide a valuable contribution to the discussion of this issue.

4. Not much in-depth exegesis from a theological point of view has been done in 2 Sam 2:1-5:5 in general, meaning that any careful exegetical work will help in gaining a better understanding of this section and its theological message.

\section{Scope and Delimitations}

This study views the biblical text of 1 and 2 Samuel as an inspired, unified and carefully crafted work of literary art that was written very intentionally to convey a theological message to the reader. For this reason, the text of 2 Sam 2:1-5:5 will be examined in its final form as it is found in Biblia Hebraica Stuttgartensia. Though every effort will be made to determine the best reading of the text, the focus of this examination will not be textual criticism, but rather an interpretation based on a close reading of the text. This also means that the study will not deal with any issues regarding the possible pre-history of the text. There will be no attempt to determine the sources behind the text or to reconstruct the textual development. Furthermore, the study will not concern itself with questions of introduction such as the date and authorship of 1 and 2 Samuel or the date of the events described therein. Nevertheless, the basic historicity of these events as 
they are portrayed in the biblical text, including 2 Sam $2: 1-5: 5$, is assumed. ${ }^{15}$ This is based not only on the testimony of Scripture itself, but also on the firm conviction that the theological message which a biblical author seeks to convey through his literary presentation of a certain event is valid and can develop its full meaning and power only if that event really happened.

Exegesis of 2 Sam 2:1-5:5 will be as comprehensive as possible insofar as it relates to the issue of the nature of David's reign in this section. Also, though the primary focus of this study is 2 Sam $2: 1-5: 5$, the immediate and wider context of this section will be taken into consideration whenever the text itself suggests that this is warranted or necessary. The objective in such instances will not be to provide a complete analysis of these related texts, but to determine what bearing they have on the issue of the nature of David's reign in 2 Sam 2:1-5:5.

\section{Methodology}

Following a review of recent scholarly literature on 2 Sam 2:1-5:5 in the present Chapter, an exegetical analysis of each of the literary units within 2 Sam 2:1-5:5 is presented in Chapters 2-4. In each case, this analysis consists of four steps. First, the scope of the literary unit is defined. Second, the structure of the unit is analyzed and its implications with regard to the nature of David's kingship are noted. This is followed by a close reading of the text of the unit as an intentionally written, carefully crafted and

${ }^{15}$ For discussion of this issue see, e.g., Kenneth Kitchen, On the Reliability of the Old Testament (Grand Rapids, MI: Eerdmans, 2003), 81-158. 
coherent narrative that focuses especially on the literary features of the text such as the repetition of keywords and phrases, and terminological and thematic links to the immediate and wider context of the unit. ${ }^{16}$ In a fourth step, the implications concerning the nature of David's kingship that have emerged from the close reading are summarized. Chapter 5 then presents a comprehensive summary of the findings and conclusions of the research.

\section{Review of Literature}

As was already noted above, no major study has focused exclusively on 2 Sam $2: 1-5: 5$ in general or more specifically on the issue of the nature of David's kingship within this particular section of 2 Samuel. However, several studies have analyzed 2 Sam 2:1-5:5 as part of a larger work and/or discussed the issue of how David is portrayed in this passage. These will now be briefly examined.

\section{Hans-Ulrich Nübel}

Hans-Ulrich Nübel's dissertation entitled 'Davids Aufstieg in der Frühe israelitischer Geschichtsschreibung” was completed in 1959. Following Meyer's proposal that behind the so-called history of David's rise comprising 1 Sam 16-2 Sam 9 are the remains of a great work of history, Nübel identifies this work as the so-called Grundschrift (Gr.) that was later edited to yield the so-called Bearbeitung (B.). ${ }^{17}$ To

\footnotetext{
${ }^{16}$ The emphasis placed on the literary aspects of the texts does not mean that grammatical and linguistic features will be completely ignored. However, no comprehensive linguistic analysis will be offered by this study.

${ }^{17}$ Nübel, “Davids Aufstieg," 19.
} 
support this assertion, Nübel devotes the first part of his study to a stylistic analysis of 1 Sam 16-2 Sam 9, noting all the insertions into the Gr. undertaken by the B. With

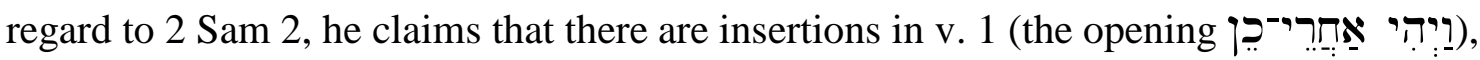
in v. 9 (the last three territories prefixed by עֵל ), and in v. 10 (the first half of the verse concerning Ish-boshet). ${ }^{18}$ In chapter 3, vv. 2-6a (list of David's sons), 17a (Abner's communication with the elders of Israel), $18 \mathrm{~b}$ (the Lord's words regarding David), 28-30 (David's declaration of innocence and his curse on Joab), and 38-39 (David's speech to his servants) have been inserted. ${ }^{19}$ According to Nübel, the same goes for vv. $2 b-3$ (background information on Beeroth), 7a (the description of Ish-boshet's murder), and 10 (David's statement regarding the execution of the Amalekite) in chapter 4, as well as for vv. $2 \mathrm{~b}$ (the Lord's words regarding David) and 3a (statement that the elders of Israel came to David at Hebron) in 5:1-5. ${ }^{20}$ Following his examination of the individual chapters, Nübel presents a list of the vocabulary of the author of the Gr. and the B. in order to further support his view of a source that was later edited. ${ }^{21}$

In the second part of his dissertation Nübel discusses the dating and purpose of both the Gr. and its edited version. In his view, the Gr. was composed around the time of David, while the B. was produced sometime during the time of the Northern Kingdom. ${ }^{22}$ Whereas the purpose of the Gr. is to vividly depict the help of Yahweh and to teach that

\footnotetext{
${ }^{18}$ Nübel, "Davids Aufstieg," 67-69.

${ }^{19}$ Nübel, "Davids Aufstieg," 69-72.

${ }^{20}$ Nübel, "Davids Aufstieg," 72-73.

${ }^{21}$ Nübel, "Davids Aufstieg," 100-121.

${ }^{22}$ Nübel, "Davids Aufstieg,” 124; 147.
} 
this help may also be expected in the future, the B. introduces the element of the law into the story as that which provides instruction instead of the events themselves. ${ }^{23}$ Thus the events are divested of the aspect of the promise and the concept of obedience is emphasized. ${ }^{24}$ Other new aspects that are introduced by the B. are repentance and the prophetic word of God. ${ }^{25}$ Finally, instead of focusing on the relationship between God and the king, B. emphasizes the relationship between Yahweh and the people. ${ }^{26}$ Yet in the end, the goal of this later historiography is the same as that of the former: "der Mensch soll vor Gott gebeugt und wieder aufgerichtet werden, um die Sprache Gottes zu verstehen, die jetzt auf zweierlei Weise zu ihm kommt - im Ereignis und im Prophetenmund. ‘27

\section{Friedrich Mildenberger}

The next major study on the history of David's rise was Friedrich Mildenberger's dissertation Die vordeuteronomistische Saul-Davidüberlieferung which was completed in 1962. ${ }^{28}$ Like Nübel, Mildenberger argues that the original history of David's rise was revised by a later editor. In his view, this editor, whom he designates as N., either belonged to prophetic circles in northern Israel or closely identified with prophetic

\footnotetext{
${ }^{23}$ Nübel, "Davids Aufstieg,” 141-45; 147-49.

${ }^{24}$ Nübel, "Davids Aufstieg," 148.

${ }^{25}$ Nübel, "Davids Aufstieg,” 148-49.

${ }^{26}$ Nübel, "Davids Aufstieg," 149.

${ }^{27}$ Nübel, "Davids Aufstieg," 149.

${ }^{28}$ Friedrich Mildenberger, "Die vordeuteronomische Saul-Davidüberlieferung” (Diss., Eberhard
} Karls Universität Tübingen, 1962). 
traditions and was most likely among the fugitives that sought refuge in Judah when the northern kingdom fell. ${ }^{29}$ Because of this, he incorporated not only northern Israelite but also Jerusalemite traditions into his revision. ${ }^{30}$ At the same time he sought to merge the northern-prophetic view of kingship with the Jerusalemite ideology of kingship. ${ }^{31}$ The ultimate purpose of the editor is to explain the fall of the northern kingdom, but at the same time to point to the Davidic kingdom as the channel through which God will continue to work for the salvation of his people. ${ }^{32}$

Having discussed the origin, extent and ideology of the revision, Mildenberger turns his attention to what he believes to be the original version of the history of David's rise in the second part of his study. In contrast to the majority view, he proposes that the original work did not begin in 1 Sam 16:14 but already in 1 Sam 13, and that it concluded not in 2 Sam 5:10 but in 2 Sam 9. ${ }^{33}$ Just as the intent of the succession narrative is to legitimize Solomon's accession to the throne, so the history of David's rise seeks to justify David's succession of Saul. ${ }^{34}$ In both cases the Tendenz of the source is conveyed through key statements by the main characters which in the case of the history of David's rise climax in David's prayer in 2 Sam $7 .{ }^{35}$ In Mildenberger's view, the emphasis on the

\footnotetext{
${ }^{29}$ Mildenberger, "Die vordeuteronomische Saul-Davidüberlieferung," 35.

${ }^{30}$ Mildenberger, "Die vordeuteronomische Saul-Davidüberlieferung," 30-35

${ }^{31}$ Mildenberger, "Die vordeuteronomische Saul-Davidüberlieferung," 55-58.

${ }^{32}$ Mildenberger, "Die vordeuteronomische Saul-Davidüberlieferung," 58.

${ }^{33}$ Mildenberger, "Die vordeuteronomische Saul-Davidüberlieferung,” 119-25.

${ }^{34}$ Mildenberger, "Die vordeuteronomische Saul-Davidüberlieferung," 101.

${ }^{35}$ Mildenberger, "Die vordeuteronomische Saul-Davidüberlieferung," 120.
} 
legitimacy of David's kingship suggests that the original history of David's rise was composed at a time when that legitimacy was questioned. He therefore dates it to the time of the collapse of the Davidic empire after the death of Solomon. ${ }^{36}$

According to Mildenberger, the original history of David's rise is characterized by great unity and high literary quality. The author has carefully arranged individual scenes into larger units of meaning ("Sinnabschnitte") that are clearly linked in order to carry the tension over from one passage to the next until the final solution is presented in the concluding unit. ${ }^{37}$ The characters are largely presented from an emotional perspective. David is portrayed as a sincere and pure individual who is faithful and consistent in his emotions that find their purest expression in the friendship with Jonathan. ${ }^{38}$ Because the author seeks to keep David away from any wrong, David does not appear as a man of action, but rather as one who waits and allows events to run their course. ${ }^{39}$ Just like the rest of the original history of David's rise, this glorified portrayal of David must not be mistaken for an accurate representation of historical events. ${ }^{40}$ The intent of the history is not to describe what actually happened, but to justify the right of the house of David to the throne of Israel. ${ }^{41}$

With regard to 2 Sam 2:1—5:5, Mildenberger believes that 2 Sam 2:1-7 serves as

\footnotetext{
${ }^{36}$ Mildenberger, "Die vordeuteronomische Saul-Davidüberlieferung," 163-64.

${ }^{37}$ Mildenberger, "Die vordeuteronomische Saul-Davidüberlieferung," 145-56.

${ }^{38}$ Mildenberger, “Die vordeuteronomische Saul-Davidüberlieferung,” 157.

${ }^{39}$ Mildenberger, "Die vordeuteronomische Saul-Davidüberlieferung," 158.

${ }^{40}$ Mildenberger, "Die vordeuteronomische Saul-Davidüberlieferung," 156-58.

${ }^{41}$ Mildenberger, "Die vordeuteronomische Saul-Davidüberlieferung,” 177.
} 
the conclusion to the account of Saul's death which began in 1 Sam $31 .{ }^{42} 2$ Sam 2:84:12 are in his view "im Wesentlichen unversehrt erhalten und nur durch eine Reihe von Einschüben und Glossen erweitert." ${ }^{43} 2: 10 \mathrm{a}, 11$ and 5:4-5 are assigned to the Deuteronomist, while 3:18 and 5:1-2 were inserted by the prophetic editor. 2:14-16 could be regarded as an expansion. The list of David's sons in 3:2-5 is certainly an addition. 3:14 and 4:4 do not fit into the context. 4:2b, 3 are a gloss. In 3:15 "Ishbosheth" should be replaced with “Abner.” Therefore, only 2:8-9, 10b, 12-13, possibly 14-16, 17-3:1, 6$13,15-17,19-4: 2 \mathrm{a}, 5-12$ and 5:3 were part of the original history of David's rise. ${ }^{44}$

\section{Rolf A. Carlson}

Rolf A. Carlson's book David, the Chosen King: A Tradicio-Historical Approach to the Second Book of Samuel was published in $1964 .{ }^{45}$ Carlson's focus is on the final stage of the redactional history of 2 Samuel. ${ }^{46}$ Following Noth, he believes that 2 Samuel is part of the Deuteronomistic history comprising Deuteronomy to 2 Kings. Contrary to Noth, however, he argues that the work was written by a group rather than a single author. ${ }^{47}$ This so-called "D-group" had a definite ideology which they sought to bring the texts they worked with into conformity with. Because of the D-group's respect for

${ }^{42}$ Mildenberger, "Die vordeuteronomische Saul-Davidüberlieferung," 116-17.

${ }^{43}$ Mildenberger, "Die vordeuteronomische Saul-Davidüberlieferung," 117.

${ }^{44}$ Mildenberger, "Die vordeuteronomische Saul-Davidüberlieferung,” 117-18.

${ }^{45}$ Rolf A. Carlson, David, the Chosen King: A Tradicio-Historical Approach to the Second Book of Samuel. Stockholm: Almqvist \& Wiksell, 1964.

${ }^{46}$ Carlson, David, the Chosen King, 22.

${ }^{47}$ Carlson, David, the Chosen King, 23. 
tradition, Carlson argues that this was achieved not so much through reshaping of the material, but rather through compositional technique and association, through he admits that "there is the possibility that the traditionists responsible for the final form of a pericope could have reshaped a given unit, at least to some extent." ${ }^{, 48}$ In his analysis of 2 Samuel, Carlson therefore seeks to "illustrate the way in which the D-group joins together unit after unit on the principle of association, i.e. by the use of similar or contrasting elements supported by different catch-words (Stichworte) or verba associandi, which may be of either formal or material character."49

In the first chapter of his study, Carlson analyzes 2 Sam $2-5$. In his view, this section consists of two parts, namely chapters $2-4$ and chapter 5 . Chapters $2-4$ are in turn divided into two parts: an introduction in vv. 1-11 and "the actual corpus, 2:12 4:12." ${ }^{50}$ In both parts Carlson notes various links to previous passages: the mention of David's two wives in 2:2 links 2:1-4a to 1 Sam 25 and 2 Sam 13, 2:4b-7 is related to 1 Sam 31:11-13, and 4:1-12 has a number of parallels to 2 Sam 1 . He also points out that the number three plays an important role in chapters $2-4: 2: 1-11$ is divided into three parts, there are three sons of Zeruiah, twelve young men from each side and 360 fallen Israelites, six sons of David, and the expression "send messengers" occurs three times in 3:7-39. Furthermore, Carlson notes that 3:2-5 and 3:7-16 contain "related motifs." 51

\footnotetext{
${ }^{48}$ Carlson, David, the Chosen King, 22.

${ }^{49}$ Carlson, David, the Chosen King, 35.

${ }^{50}$ Carlson, David, the Chosen King, 49-50.

${ }^{51}$ Carlson, David, the Chosen King, 49-51.
} 


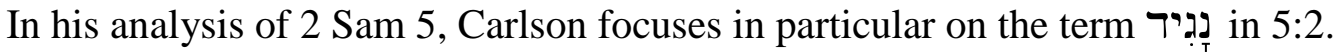

He argues that in the D-work this term has the meaning "ideal shepherd" and "is a form of Deuteronomic definition of the national leader as the Deuteronomists felt he ought to be." ${ }^{52}$ In his view, it functions in particular as a "motif of contrast" between Saul and David, who are both פָָגִ "of my people Israel" and whose task is to "save my people from the hand of the Philistines." 53

\section{Artur Weiser}

In 1966 Artur Weiser published an article entitled "Die Legitimation des Königs David. Zur Eigenart und Entstehung der sogen. Geschichte von Davids Aufstieg." As the title indicates, the main focus of Weiser's study is on the origin and nature of the socalled history of David's rise. Following Rost, Weiser distinguishes the history of David's rise from the source immediately following it, the so-called succession narrative. While he considers the latter to be a well-crafted, seamless work of art in which all the individual scenes have been skillfully intertwined, the former is, in his view, composed of various traditions of unknown origin that have been arranged in chronological sequence to give the appearance of a historical narrative, as is made evident among other things by the fact that several passages, such as 2 Sam $2: 1$ or $3: 2-5$, lack a thematic connection to

\footnotetext{
${ }^{52}$ Carlson, David, the Chosen King, 54.

${ }^{53}$ Carlson, David, the Chosen King, 54-55.
} 
what immediately precedes them. ${ }^{54}$ The result is a work having a certain mosaic character ${ }^{55}$ The unification of the source is achieved "by the presence of common motifs, such as the battles with the Philistines or David's flight from Saul." ${ }^{, 56}$

In contrast to Alt, Noth and Rost, Weiser believes that the history of David's rise begins in 1 Sam 16:1 rather than in 16:14, since the story of David's anointing in 16:1-13, though certainly of a later date than the other pericopes in the narrative and thus less historical, supports the general Tendenz of the source, which is to show that David was legitimately appointed by God. ${ }^{57}$ According to Weiser, this Tendenz is made evident not only by repeated motifs such as the phrase "The Lord is with him" and the frequent consultation with the oracle of God but also by the brevity of the account of David's anointing as king of Judah in 2 Sam 2:4 as well as by the explanation of the author regarding David's anointing as king over Israel in 2 Sam 5:3 which he has placed in the mouth of all the tribes of Israel in vv. 1-2.58

Weiser also has a different view than Alt, Noth and Rost with regard to where the source ends, arguing that it does not conclude with 2 Sam 5:12 but also includes 2 Sam 6 and 7, since these chapters also support the Tendenz of the source. ${ }^{59}$ Though chapter 7 developed independently of the history of David's rise, the author of the source used it as

\footnotetext{
${ }^{54}$ Weiser, "Legitimation des Königs David,” 329-30.

${ }^{55}$ Weiser, "Legitimation des Königs David,” 331.

${ }^{56}$ Kleven, "Hebrew Style and Narrative Sequence," 141.

${ }^{57}$ Weiser, "Legitimation des Königs David,” 326-27.

${ }^{58}$ Weiser, "Legitimation des Königs David,” 333-35.

${ }^{59}$ Weiser, "Legitimation des Königs David," 342-47.
} 
the capstone of his composition. ${ }^{60}$ This chapter is key for Weiser in determining the historical background and purpose of the source. On the basis of Hermann's view that 2 Sam 7 is patterned after the Egyptian Königsnovelle and because of the chapter's emphasis on the building of the temple and the dynastic promise, Weiser argues that the source originated during the time of Solomon with the intent of theologically justifying David's kingship and, by extension, Solomon's kingship. ${ }^{61}$ In his view, this heightened interest in the consolidation of the Davidic dynasty by means of divine legitimation must be understood against the background of the earlier rebellion of Absalom, as well as the renewed enmity from the house of Saul, as in the cases of Shimei and Sheba. ${ }^{62}$

\section{Roger L. Ward}

The history of David's rise is also the subject of Roger Ward's 1967 dissertation, entitled “The Story of David's Rise: A Tradicio-Historical Study of I Samuel xvi 14 - II Samuel v." Ward's main interest is in the history of the individual pericopes that make up the source. In contrast to Gressmann, who treated these pericopes as "particles of tradition...completely separate from any larger context," ${ }^{13}$ Ward believes that "most narratives came to the writer of 'David's Rise' not as heterogeneous fragments but as collections or complexes of tradition." ${ }^{\circ 4} \mathrm{He}$ proposes that there are six such blocks of

\footnotetext{
${ }^{60}$ Weiser, "Legitimation des Königs David,” 348.

${ }^{61}$ Weiser, "Legitimation des Königs David," 347-49.

${ }^{62}$ Weiser, "Legitimation des Königs David,” 347.

${ }^{63}$ Ward, "Story of David's Rise," 4.

${ }^{64}$ Ward, "Story of David's Rise," 4.
} 
material: (1) the young hero (1 Sam 16:14 - 19:7), (2) the fugitive (1 Sam 19:8 - 21), (3) the condottiere (1 Sam 22-26), (4) the vassal prince (1 Sam 27-2 Sam 1), (5) king over Judah (2 Sam 2-4), and (6) king over Israel (2 Sam 5). The main focus of his analysis of each section is to determine which parts belong to the original history of David's rise and which are later additions to the story. In addition, he seeks to determine the geographical origin of the six sections, tracing each to a city or region.

Of particular interest for the present study is Ward's analysis of sections 5 and 6. Because of the significant role that Hebron plays in the narratives of section 5, Ward postulates that they originated in that region and thus labels the section the "Hebron complex." ${ }^{65}$ In his view, this story cycle is the "finest piece of history writing in "the Story of David's Rise, ${ }^{, 66}$ containing only a few editorial additions. ${ }^{67}$ It was written not only to provide a historically reliable account of David's reign at Hebron, but also to convince the reader of the legitimacy of David's kingship. ${ }^{68}$

Though Ward disagrees with Alt and Noth that the anointing of David as king over Judah took place "without any religious foundation such as the designation by a prophet" $" 69$ and therefore was "a purely political act," $" 70$ he nevertheless suggests that David's course of action in 2 Sam $2-4$ is largely politically motivated. According to

\footnotetext{
${ }^{65}$ Ward, “Story of David's Rise," 140-41.

${ }^{66}$ Ward, "Story of David's Rise," 140.

${ }^{67}$ Ward explicitly mentions only three: 2 Sam 2:10-11, 3:2-5, and 4:2b-4.

${ }^{68}$ Ward, "Story of David's Rise," 141.

${ }^{69}$ Martin Noth, History of Israel (London: SCM Press, 1983), 183.

${ }^{70}$ Noth, History of Israel, 183.
} 
Ward, David sends a message to the men of Jabesh-Gilead "to expand his sphere of influence,", he wants Michal back in order "to lay claim publicly to the throne of Israel,",72 and he "conspires with Abner to...demote Joab."73 Joab's murder of Abner was "an unpardonable political blunder" ${ }^{\text {"74 }}$ in David's eyes that jeopardized his plan to unite the two kingdoms under his leadership. In response, David puts on "a display of grief"75 in order to convince the people of his innocence in the matter. Similarly, David's displeasure regarding the murder of Ish-boshet may not be sincere. ${ }^{76}$ Instead, "his stern condemnation of the sons of Rimmon may have been calculated to curry favor with Saul's relatives and former allies.",77

With regard to 2 Sam 5:1-5 Ward believes that only vv. 1-3 are part of the original text while vv. $4-5$ were added by a deuteronomic historian. ${ }^{78}$ Once again Ward disagrees with Noth that David's anointing as king over Israel was primarily a political move, since "the tribes come to Hebron expressly to acknowledge David as the one designated king by the Lord long before they were aware of it." ${ }^{79}$ Nevertheless, he suggests that the main

\footnotetext{
${ }^{71}$ Ward, "Story of David's Rise," 147.

${ }^{72}$ Ward, "Story of David's Rise,” 157.

${ }^{73}$ Ward, “Story of David's Rise,” 159.

${ }^{74}$ Ward, "Story of David's Rise," 160.

${ }^{75}$ Ward, “Story of David's Rise,” 162.

${ }^{76}$ Ward, "Story of David's Rise," 165.

${ }^{77}$ Ward, "Story of David's Rise," 165.

${ }^{78}$ Ward, "Story of David's Rise," 168.

${ }^{79}$ Ward, "Story of David's Rise," 169-70.
} 
reason for the election of David by the tribes of Israel was probably not a previous prophetic designation but rather simply the actual achievements of David. ${ }^{80}$ More important in Ward's view, however, is the similarity and continuity of the kingships of Saul and David that is emphasized in these verses. Like Saul, David is proclaimed king by "all the tribes of Israel" (v. 1; cf. 1 Sam 10:17-24), the phrase "before the Lord" is mentioned in connection with his anointing (v. 3; cf. 1 Sam 10:19, 25) and he is referred

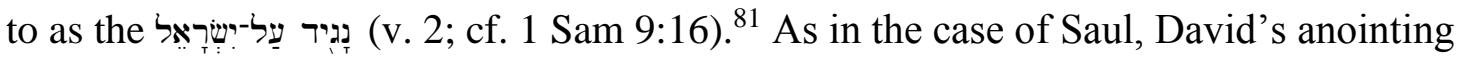
not only empowers him with authority to judge and protect Israel but also protects him from those who would plot against him. ${ }^{82}$

Based on his analysis of the history of David's rise, Ward concludes that the source presents "a substantially reliable story of David and his times" that has been embellished both stylistically and theologically by court and cult traditions in order to exculpate David. ${ }^{83}$ It therefore lacks the impartiality and objectivity of the Succession History. ${ }^{84}$ Though the ideological evaluation of David is very positive throughout the source, the diverse portraits of him in the different sections of the source reveal that the real David is "a very complex man," who is both "deeply religious... as well as a scheming politician." ${ }^{95}$

\footnotetext{
${ }^{80}$ Ward, “Story of David's Rise,” 170.

${ }^{81}$ Ward, “Story of David's Rise,” 171.

${ }^{82}$ Ward, "Story of David's Rise,” 176.

${ }^{83}$ Ward, "Story of David's Rise," 191; 196.

${ }^{84}$ Ward, "Story of David's Rise," 196-97.

${ }^{85}$ Ward, “Story of David’s Rise,” 191.
} 
The author of the source was "almost certainly a member of Solomon's court," who is here presenting the official interpretation of the court traditions by the Jerusalem palace ${ }^{86}$ While the source exalts David and defends the right of the Judean kings to rule over Israel, it is also written with the hope of uniting the pro-Saul and pro-David factions. ${ }^{87}$ This explains the "absence of unduly harsh judgments or calumnies against Saul. $"{ }^{88}$

\section{Jakob H. Grønbæk}

Jakob Grønbæk's study on the history of David's rise entitled Die Geschichte vom Aufstieg Davids (1 Sam 15 - 2 Sam. 5); Tradition und Komposition was published in 1971. Like Weiser and Ward before him, Grønbæk views the "Vorgeschichte," as he calls the history of David's rise, as an independent "Traditionskomplex" made up of largely oral traditions of Judahite, Benjaminite and possibly Ephraimite origin. ${ }^{89}$ This complex did not develop over time, but was most likely composed at some point after the division of Israel by a pro-Benjamite author living in Jerusalem with the purpose of defending Rehoboam and his kingship against Jeroboam by showing that David was the legitimate

\footnotetext{
${ }^{86}$ Ward, “Story of David's Rise,” 216.

${ }^{87}$ Ward, "Story of David's Rise," 215.

${ }^{88}$ Ward, "Story of David's Rise," 210.

${ }^{89}$ Grønbæk, Geschichte vom Aufstieg Davids, 16; 23-25.
} 
and only eligible successor of Saul. ${ }^{90}$ Thus the complex is shaped by a clear ideology and cannot be categorized as critical historiography. ${ }^{91}$

Like Ward, Grønbæk divides the history of David's rise into six parts: (1) 1 Sam 15:1—16:13, (2) 1 Sam 16:14—19:17, (3) 1 Sam 19:18—22:23, (4) 1 Sam 23:1—27:4, (5) 1 Sam 27:5-2 Sam 2:4a, and (6) 2 Sam 2:4b-5:10. ${ }^{92}$ Each of these parts is analyzed in a separate chapter of his book. Of interest for the present study is Grønbæk's analysis of 2 Sam 2:4-5:10 in chapters 5 and 6.

With regard to 2 Sam 2:1-4a, Grønbæk argues that this piece was probably not an old tradition or a tradition fragment, but was composed by the author of the history of David's rise. In his view, this is indicated not only by the terseness of the passage, by the fact that the wording is not always unambiguous but kept rather general, and the fact that the passage lacks the typical features that are characteristic of a real tradition, but also by the clear emphasis that David's accession to the throne is the will of Yahweh. ${ }^{93}$

In chapter 6 Grønbæk discusses 2 Sam 2:4b-5:10. He divides the material into four sections: (1) the civil war between Judah and Israel (2:4b-3:1), (2) Abner's death (3:2-39), (3) Eshbaal's death (4:1-12), and (4) David becomes king over Israel and makes Jerusalem his royal capital (5:1-10). In the first section, $2: 4 b-11$ serve as an introduction to the centerpiece in $2: 12-3: 1$. Verses $4 b-7$ might be a tradition fragment or - because of

\footnotetext{
${ }^{90}$ Grønbæk, Geschichte vom Aufstieg Davids, 17; 19; 35-36; 276.

${ }^{91}$ Grønbæk, Geschichte vom Aufstieg Davids, 19: „Der aufgenommene Stoff...hat...von einer bestimmten Gesamtkonzeption und Tendenz her eine Bearbeitung erfahren. Von einer kritischen Geschichtsschreibung kann allein aus diesem Grund nicht die Rede sein."

${ }^{92}$ Grønbæk, Geschichte vom Aufstieg Davids, 9-10.

${ }^{93}$ Grønbæk, Geschichte vom Aufstieg Davids, 222-23.
} 
its obvious conformity with the general purpose of the "Vorgeschichte" - could have been composed by the author. Whatever the case may be, the intent of David in these verses is clear: he wants the Jabesh-Gileadites to follow the example of the men of Judah and recognize him as Saul's rightful heir. Yet vv. 8-11 indirectly show that David's request was rejected. ${ }^{94} \mathrm{Vv} .8$ and 9 are also probably based on an old and historically valuable tradition. ${ }^{95}$ Historically speaking, the conflict between Eshbaal/Abner and David was probably provoked by the latter because of his ambitions towards the north. ${ }^{96}$

In Grønbæk’s view 2:12-3:1 is composed of two originally independent traditions in vv. 14-16 and vv. 18-25 that are connected by v. 17 . This verse, as well as 2:28 and 3:1, describe the real battle between the house of Saul and the house of David, while the other two passages describe play-wars ("Kampfspiele") in the territory of Benjamin which function as illustrations of the regular war. He sees further support for dividing 2:12 - 3:1 in this way in the fact that the opponents of David's men are called "men of Israel" in v. 17 and "Israel" in v. 28, while in the play-war episodes the term "Benjamin" is used. The use of this term shows that the conflict is primarily between Judah and Benjamin and once again highlights the intent of the whole "Vorgeschichte," which is to present the Judahite David as the legitimate heir of the Benjaminite Saul. ${ }^{97}$

Contrary to Noth, Grønbæk does not view the list of David's sons in 2 Sam 3:2-5 as an insertion by the Deutoronomist. Rather it provides the basis for the expression

\footnotetext{
${ }^{94}$ Grønbæk, Geschichte vom Aufstieg Davids, 225-26.

${ }^{95}$ Grønbæk, Geschichte vom Aufstieg Davids, 227.

${ }^{96}$ Grønbæk, Geschichte vom Aufstieg Davids, 228.

${ }^{97}$ Grønbæk, Geschichte vom Aufstieg Davids, 229-34.
} 
"house of David" in v. $1 .{ }^{98}$ Grønbæk then discusses the presentations of Abner and Joab. He notes that though Abner is really a traitor, he is praised, while the hero Joab and his brothers are portrayed negatively. The reason for Joab's rejection is the anti-judahite Tendenz of the source. Abner is praised because at least for a time he brought David closer to his goal, namely the throne of Israel $1{ }^{99}$ In reality, Abner originally wanted the throne for himself by sleeping with Saul's concubine. The author of the source, however, has distorted the historical facts in this case, as well as with regard to David's demand for Michal in vv. 12-16. Though the author makes it appear as if David and Michael were already married before, this was not really the case. The earlier reference to this marriage in 1 Sam 18 is legend. Also, Eshbaal was probably not informed of the negotiations between David and Abner, since it seems strange that Eshbaal permits the union of David and Michal whose only purpose is to secure the throne of Israel for David. However, in order to further legitimize David's union with Michal, the author makes it appear as if it was sanctioned by Eshbaal. ${ }^{100}$ Yet the main reason why 2 Sam 3 was included in the "Vorgeschichte" does not become apparent until the last section of the chapter in 3:28-39, whose purpose is to forcefully demonstrate David's innocence with regard to Abner's death. $^{101}$

With regard to the account of Eshbaal's death in 2 Sam 4, Grønbæk contends that its main intent is to clear David of any accusations that he was involved in the murder,

\footnotetext{
${ }^{98}$ Grønbæk, Geschichte vom Aufstieg Davids, 234-35.

${ }^{99}$ Grønbæk, Geschichte vom Aufstieg Davids, 236-37.

${ }^{100}$ Grønbæk, Geschichte vom Aufstieg Davids, 237-39.

${ }^{101}$ Grønbæk, Geschichte vom Aufstieg Davids, 270.
} 
though in reality he probably had a part in it. ${ }^{102}$ In Grønbæk’s view, the account is probably based on a tradition whose basic content, namely the assassination of Eshbaal and the punishment of the assassins, has been preserved. Possible additions are v. 1, vv. $2 \mathrm{~b}-4$ and the assertion of David's innocence in vv. 9-11. In contrast to the condemnation of Joab in the previous chapter which was also directed against the tribe of Judah in general, the condemnation of the assassins in $2 \mathrm{Sam} 4$ is only directed against individuals and not against the whole tribe of Benjamin. ${ }^{103}$ Grønbæk also argues that there is a clear difference in the assessment of Saul and Eshbaal. While the former is the anointed of the Lord, the latter is only a righteous man. And while Saul dies in battle, Eshbaal is killed during a noontime nap. Eshbaal is thus not viewed as a true king. In this way the source emphasizes that David and not Eshbaal is the true successor of Saul. ${ }^{104}$

In 2 Sam 5:1-5, vv. 1-2 are additions by the author of the "Vorgeschichte," while vv. 4-5 are later additions by the Deuteronomist, according to Grønbæk. ${ }^{105}$ Only v. 3 is possibly based on a tradition. In Grønbæk's view, this is supported by (1) the fact that the elders are also mentioned in the account of the anointing of David by Samuel and in connection with Abner's negotiations in 2 Sam 3:17, (2) the fact that there is no mention

${ }^{102}$ Grønbæk, Geschichte vom Aufstieg Davids, 243.

${ }^{103}$ Grønbæk, Geschichte vom Aufstieg Davids, 243-46.

${ }^{104}$ Grønbæk, Geschichte vom Aufstieg Davids, 243.

${ }^{105}$ In Grønbæk's view, such editing by the Deuteronimist is to be expected in 2 Sam 5, since that chapter marks the end of the source. (Grønbæk, Geschichte vom Aufstieg Davids, 248) 
of the conditions of the covenant between David and elders, and (3) the fact that they enter into the covenant before the Lord, which might point to the sacred site at Hebron. ${ }^{106}$

\section{David M. Gunn}

David Gunn's essay “David and the Gift of the Kingdom (2 Sam 2-4, 9-20, 1 Kgs 1-2)" proceeds from the assumption that 2 Sam $2-4$ could be connected to the so-called "Succession Narrative" in 2 Sam 9-20 and $1 \mathrm{Ki} 1-2 .{ }^{107}$ In Gunn's view, these chapters provide "a more satisfactory beginning" to that narrative than either 2 Sam 6 or 9 . He also disagrees with Rost's definition of the story as primarily a "succession history," arguing that "this is a story about David and not any successor or potential successor."108

Having established that David is the main character in the narrative, Gunn goes on to argue that the portrait of David in 2 Sam 2-4 is ambivalent. While David makes no attempt to seize the kingdom (all the initiative in this section is taken by others, such as Abner, Joab, or the sons of Rimmon), his "role is not entirely passive." 109 According to Gunn, David is not averse to the thought of gaining the kingdom as evidenced by his "elaborate dissociation" from Abner's murder and his "dramatic despatch" of the sons of Rimmon, both of which Gunn interprets as public relations exercises. ${ }^{110}$ Gunn also questions David's assessments of both Abner and Joab in 2 Sam 3. In his view, Abner

${ }^{106}$ Grønbæk, Geschichte vom Aufstieg Davids, 248-50.

${ }^{107}$ David M. Gunn, "David and the Gift of the Kingdom (2 Sam 2-4, 9-20, 1 Kgs 1-2)" Semeia 3 (1975): 14-45.

${ }^{108}$ Gunn, "Gift of the Kingdom," 15.

${ }^{109}$ Gunn, "Gift of the Kingdom," 16.

${ }^{110}$ Gunn, "Gift of the Kingdom," 16. 
may very well be a disloyal deserter trying to save his own skin, while Joab may have viewed Abner's murder as still taking place in the context of war. For Gunn, the characters in the story therefore appear "in shades of grey rather than black and white: there are elements of self-interest and deceit as well as of loyalty and self-restraint."111 And David "also has some share in this world." 112 Nevertheless, Gunn recognizes the remarkable constraint David exercises with regard to gaining the kingdom, noting that "it is this that singles him out qualitatively from the others." 113 Thus chapters $2-4$ present David as one who "is content to be given the kingdom."114

Gunn disagrees with those who view the narrative as moralizing or reflecting a certain Tendenz. In his view, the story presents "a picture of the rich variety of life that is often comic and ironic in its contrasting perspectives and conflicting norms." 115 The author is a skilled storyteller and therefore an artist rather than a propagandist or a teacher. He is not "amoral or immoral," but "has a powerful, yet sympathetic, sense of the frailty of man." "116

David Gunn's book “The Story of King David: Genre and Interpretation” builds on his essay published three years earlier. ${ }^{117}$ In the first half of the book Gunn once again

${ }^{111}$ Gunn, "Gift of the Kingdom," 18.

${ }^{112}$ Gunn, "Gift of the Kingdom," 18.

${ }^{113}$ Gunn, "Gift of the Kingdom," 18.

${ }^{114}$ Gunn, "Gift of the Kingdom," 35.

${ }^{115}$ Gunn, "Gift of the Kingdom," 36.

${ }^{116}$ Gunn, "Gift of the Kingdom," 36.

${ }^{117}$ David M. Gunn, The Story of King David: Genre and Interpretation, JSOTSup 6. (Sheffield: JSOT Press, 1978). 
seeks to demonstrate that the David narrative should not primarily be characterized as history writing, political propaganda, didactic or wisdom literature, or a combination of these, but is "first and foremost a story or tale in the sense of a work of art and entertainment." ${ }^{118}$ In support of his claim, he notes the presence of traditional patterns or motifs, such as "the judgement-eliciting parable" or "the letter of death" in the story. ${ }^{119}$ In addition, he points out patterns such as the list of provisions in 1 Sam 25 and 2 Sam 25 and the report of death in 1 Sam 4 and 2 Sam 1 that in his view are "most readily explained as the product, direct or indirect, of an oral tradition." ${ }^{120} \mathrm{He}$ thus concludes "there is evidence in the story of King David that significant elements in it have been derived from an existing story-telling tradition." ${ }^{\prime 121}$

In chapter 4 Gunn then discusses the boundaries of the story, arguing that on the ground of plot and style most of 2 Sam 2-4 and most likely also 5:1-3 should be included in the narrative as well. With regard to plot, Gunn sees at least two links between the plot of 2 Sam 2-4 and that of 2 Sam 9-20 and 1 Kgs 1-2: (1) The story of Ish-boshet's death in 2 Sam 4 provides important background for the question raised by David in 2 Sam 9:1 and (2) David's reference to the murder of Abner in 1 Kgs 2 presupposes the account of Abner's death in 2 Sam 3. ${ }^{122}$ With regard to style, Gunn demonstrates that 2 Sam 2-4 share some stylistic features such as inclusio and other

\footnotetext{
${ }^{118}$ Gunn, Story of King David, 13.

${ }^{119}$ Gunn, Story of King David, 38-49.

${ }^{120}$ Gunn, Story of King David, 49.

${ }^{121}$ Gunn, Story of King David, 61.

${ }^{122}$ Gunn, Story of King David, 68-70.
} 
forms of repetition, foreshadowing as well as vocabulary with 2 Sam $9-20$ and $1 \mathrm{Ki} 1-$ 2. ${ }^{123}$ Thus he concludes that 2 Sam $2-4$ "provides a more satisfactory beginning to the narrative than does chapter 9 (or 6)." 124

In the final chapter of his book Gunn presents his interpretation of the story. Most of this chapter is drawn from Gunn's earlier essay which was reviewed above.

Niels P. Lemche

In his article "David's Rise", Niels Lemche attempts "a re-evaluation of the career of David, which may in some aspects differ from the scholarly consensus concerning this great Old Testament personality." "25 Such a re-evaluation is necessary in his view because "most studies concerned with David's career are mere paraphrases of the narrative of 'David's Rise"” and thus do not "show that this narrative must be of dubious value as a historical source for the earlier history of David."126

Lemche agrees with most scholars that the history of David's rise was written "(a) to legitimate David's succession to the throne which rightly belonged to the house of Saul, and (b) to acquit David of charges brought against him for complicity in the disaster which ruined Saul's family." 127 It is this ideological tendency in the source that causes him to doubt its historical accuracy. He therefore proceeds to go through the source

\footnotetext{
${ }^{123}$ Gunn, Story of King David, 76-81.

${ }^{124}$ Gunn, Story of King David, 84.

${ }^{125}$ Lemche, “David's Rise," 3.

${ }^{126}$ Lemche, “David's Rise,” 3.

${ }^{127}$ Lemche, “David's Rise," 2.
} 
section by section in order to determine what actually took place historically speaking. The portrait of David that emerges from his analysis is, not surprisingly, much more negative than the one presented in the source. In Lemche's view, David's anointing in 1 Sam 16 is "totally unhistorical" and David's victory over Goliath in 1 Sam 17 "may have never happened." ${ }^{128}$ When David came to Saul's court, he "deliberately worked his way up to the highest position." 129 While Saul was aware of the threat which David posed and naturally tried to get rid of him, Jonathan naively acted against his own interests by siding with David. ${ }^{130}$ During his flight from Saul David deliberately tricked the priests into providing him with equipment and weapons and thus was indirectly responsible for their death. Yet the author never criticizes David for this but puts all the blame on Saul. ${ }^{131}$ Later, David "evidently had no serious scruples about transferring his allegiance to his former enemies" when he moved to Philistine territory. In his dealings with Nabal, David "committed a really dirty trick..., frightening a man to death and stealing his wife." $132 \mathrm{He}$ then tried to pave his way back to Israel through bribery of Judah. ${ }^{133}$ He employed the same tactics in order to gain control over all of Saul's kingdom. ${ }^{134}$

\footnotetext{
${ }^{128}$ Lemche, "David's Rise," 4.

${ }^{129}$ Lemche, “David's Rise,” 8.

${ }^{130}$ Lemche, "David's Rise," 8.

${ }^{131}$ Lemche, “David's Rise,” 9.

${ }^{132}$ Lemche, “David's Rise," 12.

${ }^{133}$ Lemche, "David's Rise," 14-15.

${ }^{134}$ Lemche, “David's Rise," 16.
} 
Of particular interest to the present study is Lemche's analysis of 2 Sam 2:1-5:5. In his view, the main burden of the author in this section is to clear David of having any part in the deaths of Abner and Ish-boshet. ${ }^{135}$ Yet this does not mean that David was innocent. To the contrary, the fact that he profited from both deaths "may be considered an indication of his guilt." ${ }^{\prime 136} \mathrm{He}$ sees further evidence for David's involvement in the fact that David does not have Joab prosecuted and in the very compromising behavior of the two brothers who assassinate Ish-boshet, who immediately go to Hebron to pick up their reward. ${ }^{137}$ In order not to raise any suspicions, David thus had to have them executed. The only reason David mourned after Abner's death was politics - it "was part of his propaganda campaign launched at the inhabitants of Ishbaal's kingdom."138

In summary, David was a very normal ruler who "unscrupulously and consistently followed his own aims" in order to get to the highest position in the country. ${ }^{139} \mathrm{He}$ was thus not fundamentally different from other ancient rulers such as Caesar and Augustus. ${ }^{140}$

\footnotetext{
${ }^{135}$ Lemche, “David's Rise," 14.

${ }^{136}$ Lemche, "David's Rise," 17.

${ }^{137}$ Lemche, "David's Rise," 16-17.

${ }^{138}$ Lemche, "David's Rise," 17.

${ }^{139}$ Lemche, “David's Rise," 18.

${ }^{140}$ Lemche, "David's Rise," 18.
} 


\section{P. Kyle McCarter}

In 1980 P. Kyle McCarter published an article on the history of David's rise entitled "The Apology of David." 141 His study is based on the thesis that the history of David's rise is made up of "an underlying, more or less unified composition by an author with a clear point of view," which runs from 1 Sam 16:14 to 2 Sam 5:10. ${ }^{142}$ To this original narrative "various secondary materials, some of them deuteronomistic, have accrued." ${ }^{143}$ In the first part of his article McCarter thus presents a brief summary of his more extended discussion of additions to the original narrative found in his Anchor Bible commentary on 1 Samuel. ${ }^{144}$ In his view, deuteronomistic additions are found in the story of David and Goliath (1 Sam 17), the story of David and Jonathan (1 Sam 20), the first account of David's refusal to take Saul's life (1 Sam 23:14-24:23), Abigail's second speech (1 Sam 25:28-31) and in the account of David's reign in Hebron (2 Sam 2-5). With regard to 2 Sam $2-5$, he argues that chronological formulae and thematic interpolations were added in $2: 10 \mathrm{a}$ and 11 , in $3: 9-10,18 \mathrm{~b}$, and in $5: 1-2,4-5 .^{145}$

In the second part of his study McCarter comments on the purpose of the original narrative. He believes it was written from "a political point of view supported by theological interpretation of the events it recounts...to show that David's accession to the throne was lawful and that the events leading up to his proclamation as king over all

\footnotetext{
${ }^{141}$ P. Kyle McCarter, “The Apology of David,” Journal of Biblical Literature 99 (1980): 489-504.

${ }^{142}$ McCarter, “Apology of David,” 491.

${ }^{143}$ McCarter, “Apology of David,” 491.

${ }^{144}$ See P. Kyle McCarter, 1 Samuel, AB 8 (Garden City, N.Y.: Doubleday, 1980), 12-30.

${ }^{145}$ McCarter, “Apology of David,” 493.
} 
Israel were guided by the will of the god of Israel." ${ }^{146}$ In contrast to Grønbæk and others, who date the history of David's rise to the time after the division of the kingdom, McCarter proposes that the earliest version of the history may date to the reign of David. In his view, this early date is supported by the striking similarities between the history and royal apologies such as the apology of Hattushilish III in Hittite historiographical literature. ${ }^{147}$

The third part of the study is devoted to a thematic analysis of the history. In McCarter's view, the main intent of the author of the history is to clear David from the following charges: (1) David sought to advance himself at court at Saul's expense, (2) David was a deserter, (3) David was an outlaw, (4) David was a Philistine mercenary, (5) David was implicated in Saul's death, (6) David was implicated in Abner's death and (7) David was implicated in Ishbaal's death. According to McCarter, it seems likely that some or all of these charges were actually brought against David during his lifetime, which he views as further support for his proposal that the history in its original form originated in David's time. ${ }^{148}$

In the fourth part of the study McCarter reconsiders the two central theological claims made in the narrative in light of his thematic analysis. He argues that neither God's abandonment of Saul expressed in the negative claim that the Spirit of the Lord departed from Saul nor God's choice of David indicated by the positive claim that the

\footnotetext{
${ }^{146}$ McCarter, “Apology of David,” 494-95.

${ }^{147}$ McCarter, “Apology of David,” 495-98.

${ }^{148}$ McCarter, “Apology of David," 502.
} 
Lord was with David are not explained in the original composition. The Lord's attitude toward Saul and David is therefore "a matter of the mystery of the divine mind." ${ }^{149}$ Thus both Saul and David are caught up in events they cannot control and from which they cannot extricate themselves. This reality "furthers the apologetic purposes of the narrator."150

\section{James Vanderkam}

As the title already suggests, the purpose of James Vanderkam's article "Davidic Complicity in the Deaths of Abner and Eshbaal: A Historical and Redactional Study" is to investigate the possibility that David was in some way involved in the assassinations of Abner and Eshbaal. While he admits that according to the text itself David was not only not involved in the murders but actually horrified at them, he argues that an examination of the larger contexts of 2 Sam 3-4 should lead both the historian and the redactional critic to come to a different conclusion. ${ }^{151}$

The first part of Vanderkam's study is dedicated to a historical analysis of 1 Sam 16-2 Sam 5. Since these chapters have been subjected to "heavily pro-davidic editing" they cannot be considered "historiography in the modern sense of that term." ${ }^{\prime 52}$ Only when all the editorial features are removed does the real history, and with it a more candid portrait of David, emerge. Thus, Vanderkam contends that in reality David set his

\footnotetext{
${ }^{149}$ McCarter, “Apology of David,” 503.

${ }^{150}$ McCarter, “Apology of David,” 503.

${ }^{151}$ Vanderkam, "Davidic Complicity," 521.

${ }^{152}$ Vanderkam, "Davidic Complicity," 523.
} 
sights on Saul's throne from early on, since he not only gathered a group of fighting men around himself but also made a pact with Jonathan that involved David's kingship over Judah and secured priestly favor by welcoming Abiathar into his group. ${ }^{153}$ Vanderkam even goes so far as to suggest that David probably already reigned as king at Hebron while Saul was still alive. Since David was king at Hebron for seven and a half years and Eshbaal reigned for only two years, Vanderkam argues that David must have reigned at Hebron for five and a half years prior to Saul's death if Eshbaal directly succeeded his father. ${ }^{154}$ Furthermore, if David's wife Ahinoam of Jezreel is indeed identical to Saul's wife as some scholars have suggested, David's marriage to her "may have announced... his new kingly status." ${ }^{155}$ According to Vanderkam, David was thus not as faithful and deferential to Saul as the edited version of the history would cause us to believe.

In light of this more negative assessment of David it is not surprising that Vanderkam goes on to argue that David most likely had a hand in Abner's death. He asserts that it is not unreasonable to believe this since (1) Abner had great political and military influence in Eshbaal's kingdom, (2) David had his eyes on Eshbaal's realm as shown by his dealings with the men of Jabesh Gilead, the fact that he demanded Michal back and entered into alliances with nations that bordered on Eshbaal's lands and (3) the pro-davidic editor tries too hard to present David as completely innocent in this matter.

\footnotetext{
${ }^{153}$ Vanderkam, "Davidic Complicity," 524-27.

${ }^{154}$ Vanderkam, "Davidic Complicity," 527-28.

${ }^{155}$ Vanderkam, "Davidic Complicity," 528.
} 
Though Vanderkam acknowledges that his assertion contradicts the present form of the narrative, he contends that it is historically more accurate. ${ }^{156}$ With regard to Eshbaal's death, on the other hand, he argues that a historical analysis yields no hard evidence to support the conclusion that it was arranged by David. ${ }^{157}$

In the second part of his study Vanderkam turns to a redactional analysis that focuses in particular on the confrontation between David and Shimei in 2 Sam 16:5-13. Vanderkam argues that David in these verses acknowledges that Shimei's charge is true: he is indeed responsible for the deaths of members of Saul's family. ${ }^{158}$ This raises the question which Saulides Shimei and David meant. Vanderkam agrees with a number of other scholars that the historical referents of Shimei's curse and David's confession are the seven male members of Saul's family killed by the Gibeonites in 2 Sam 21. This conclusion is based on the assumption that 2 Sam 21 originally preceded 2 Sam $16 .{ }^{159}$ Vanderkam then goes on to argue that the final editor of the Court History moved 2 Sam 21 to its present position in order to implicate David in the deaths of both Abner and Eshbaal since they are the only members of Saul's house whose death is recorded prior to 2 Sam 16. Hence, the redactional referents of Shimei's curse and David's confession are Abner and Eshbaal. The redactional analysis thus clarifies that David was also responsible for Eshbaal's death. ${ }^{160}$

\footnotetext{
${ }^{156}$ Vanderkam, "Davidic Complicity,” 529-33.

${ }^{157}$ Vanderkam, “Davidic Complicity,” 529, 534.

${ }^{158}$ Vanderkam, "Davidic Complicity," 535-37.

${ }^{159}$ Vanderkam, "Davidic Complicity," 537-39.

${ }^{160}$ Vanderkam, "Davidic Complicity," 539.
} 


\section{Keith W. Whitelam}

In his article entitled "The Defence of David" Keith Whitelam argues that the biblical account of David which runs from 1 Sam 9 to $1 \mathrm{Ki} 2$ should be understood as a piece of royal propaganda written for the elite of society by which the Davidic monarchy sought to justify David's seizure of Saul's throne and "present an interpretation of the general situation which held the assent of the population, or at least those parts of the population which were a threat or potential threat to his ambitions." 161 This would have been necessary since the Davidic monarchs were unable to rule by force alone, as the rebellions of Absalom and Sheba as well as the confrontation between Rehoboam and the tribes of Israel demonstrate. ${ }^{162}$ The whole account is characterized by a "defensive attitude," with the narrator being "particularly concerned to deny any charge of bloodguilt against David." ${ }^{\prime 63}$ In spite of the apologetic nature of the account, however, it is "remarkably objective." 164 According to Whitelam, this objectivity "stems...from a technique employed by the Davidic bureaucracy to allay suspicions and protect the image of the king of his successors." 165 Only when this "objective façade" is removed, does the author's true view of people and events emerge. The account thus does not reflect

${ }^{161}$ Keith W. Whitelam, “The Defence of David,” Journal for the Study of the Old Testament 29 (1984), 62. Emphasis his.

\footnotetext{
${ }^{162}$ Whitelam, "Defence of David," 62.

${ }^{163}$ Whitelam, "Defence of David," 75, 73.

${ }^{164}$ Whitelam, "Defence of David," 78.

${ }^{165}$ Whitelam, "Defence of David," 78.
} 
historical reality but gives insight into the "highly subjective self-perception of the Davidic monarchy." 166

\section{Terence J. Kleven}

Terence Kleven's dissertation entitled Hebrew Style and Narrative Sequence in II Samuel I-VII was completed in 1990. Against those who believe that the narrative in 2 Sam $1-7$ consists of several different sources and is so disunified that it cannot be understood as describing a sequence of events culminating in 2 Sam 7, Kleven contends that the very argument used to reach this conclusion, namely the various aspects of Hebrew style, "can be more adequately understood as purposeful uses of the Hebrew language for the creation of a narrative" that "can and should be read as a coherent sequence of events." ${ }^{167}$ Kleven further argues that rather than depicting a David that is different from the historical David, the narrative portrays a complex individual, who nevertheless consistently (1) exercises restraint with regard to Saul's house, (2) seeks to unify Judah and Israel both politically and religiously and (3) is willing to either consult God before taking action or conform to God's direction. ${ }^{168}$

Kleven's study is divided into two parts. In the first part, Kleven reviews the most important previous studies on or relating to 2 Sam $1-7$. The second part is devoted to a stylistic analysis of each chapter that seeks to show how "the Hebrew style of the narrative functions purposefully in the creation of a unified and forceful depiction of this

\footnotetext{
${ }^{166}$ Whitelam, "Defence of David,” 79. Emphasis his.

${ }^{167}$ Kleven, "Hebrew Style and Narrative Sequence," iii.

${ }^{168}$ Kleven, "Hebrew Style and Narrative Sequence," iii-iv.
} 
portion of David's life." 169 Of interest for the present study is Kleven's examination of 2 Sam 2-5. In his analysis of 2 Sam 2 he calls attention in particular to the complexity in the portrayal of the main actors David, Abner and Joab as evidence against the view that the narratives were edited to reflect the ideology of the history of David's rise. ${ }^{170}$ Likewise, he argues that the proposed insertions in 2 Sam 3 which are often cited as evidence for a later reworking of the chapter for a particular Tendenz "are not necessary accounts of the rhetoric of the chapter." 171 The list of David's sons in vv. 2-5, for example, may have been placed at this particular point in the narrative very purposefully in order to further confirm the passage of time explicitly noted in v. $6 .{ }^{172}$ With regard to 2 Sam 4, Kleven concludes that there is "no hint of David's complicity in Ish-bosheth's death" in the depiction of the narrative. He criticizes McCarter and Vanderkam for casting suspicion on David without offering adequate textual support for their reading of the text. ${ }^{173}$ Furthermore, he calls into question the view that the purpose of the narrative in 2 Sam 4 is show how God used the misdeeds of the sons of Rimmon to bring David to the throne, suggesting instead that "the narrative allows for a careful recognition of the consequences of human doings rather than simply affirming that God's actions are subtly behind all human actions." ${ }^{" 174}$

\footnotetext{
${ }^{169}$ Kleven, "Hebrew Style and Narrative Sequence," iv.

${ }^{170}$ Kleven, "Hebrew Style and Narrative Sequence," 262.

${ }^{171}$ Kleven, "Hebrew Style and Narrative Sequence," 296.

${ }^{172}$ Kleven, "Hebrew Style and Narrative Sequence," 266.

${ }^{173}$ Kleven, "Hebrew Style and Narrative Sequence," 310-11.

${ }^{174}$ Kleven, "Hebrew Style and Narrative Sequence," 311-12.
} 


\section{Jan Fokkelman}

The most comprehensive literary analysis of 2 Samuel 2:1-5:5 to date is found in the third volume of Jan Fokkelman's four volume series on 1 and 2 Samuel entitled Throne and City. ${ }^{175}$ Fokkelman's aim throughout the series is "to let the Books of Samuel speak fully for themselves through intrinsic study." ${ }^{176}$ Based on the premise that the text is a work of art which "has been created to be known" and whose content and meaning are inextricably linked to its literary form, he presents a careful reading of the text in its final form that pays particular attention to stylistic and structural aspects. ${ }^{177}$ This involves not only "a meticulous and complete language analysis," but also a special attentiveness to patterns and repetitions as well as to such things as characterization, point of view or spatial imagery with the intent of providing a complete or full interpretation of the Samuel books. ${ }^{178}$

Fokkelman views 2:1-5:5 as a distinct group of narratives (“Act IX") that together with the stories in 5:6-8:18 (“Act X") form a larger unit (2 Sam 2-8) connecting the account of Saul's rejection and downfall described in 1 Sam $13-2$ Sam 1 with the chapters dealing with "David's moral and psychological decline" (2 Sam 9-1 Ki 2). ${ }^{179}$ His detailed analysis of 2:1-5:5 leads him to conclude that the events reported

\footnotetext{
${ }^{175}$ Jan Fokkelman. Throne and City, vol. 3 of Narrative Art and Poetry in the Books of Samuel: A Full Interpretation Based on Stylistic and Structural Analyses. (Assen, Netherlands: Van Gorcum, 1990).

${ }^{176}$ Jan Fokkelman. King David, vol. 1 of Narrative Art and Poetry in the Books of Samuel: A Full Interpretation Based on Stylistic and Structural Analyses. (Assen, Netherlands: Van Gorcum, 1981), 1.

${ }^{177}$ Fokkelman, King David, 1.

${ }^{178}$ Fokkelman, King David, 12.

${ }^{179}$ Fokkelman, Throne and City, 10.
} 
in these chapters are arranged in concentric fashion with the conflict between Abner and Ish-boshet and Abner's subsequent defection to David in 3:6-21 serving as the central scene that marks the turning point of the entire Act. ${ }^{180}$ The arrangement underscores Fokkelman's view that - at least at the macro-level of the plot - Abner is "the great initiator" and thus "the hero and the subject" of the Act. ${ }^{181}$ David, on the other hand, is "the receiver" who "takes virtually no initiative" but continually benefits from the efforts of others. Far from being a sign of his lack of power, David's "non-action acts like a magnet which determines a force-field, making particles behave in an ordered fashion." 182 In the end, therefore, everyone and everything adapts to David and his throne.

On another level, however, namely that of the composition of the Samuel books, David has been and still is the hero who is to receive the throne of Israel from God. Because of this, it would have been "extremely undesirable" if Abner had been able to take any credit for putting David on the throne. Therefore, Fokkelman views Joab's desire for revenge as "an instrument of Providence which has guided David on the way to the throne and wants to see him get there without too much moral damage." ${ }^{\prime 183} \mathrm{By}$ preventing Abner from completing his quest, Joab's action ensures that David's quest is brought to a satisfactory conclusion. In this way, the crossing of the lines of David and Saul that began in 1 Samuel continues in the present Act.

\footnotetext{
${ }^{180}$ Fokkelman, Throne and City, 144.

${ }^{181}$ Fokkelman, Throne and City, 144.

${ }^{182}$ Fokkelman, Throne and City, 145.

${ }^{183}$ Fokkelman, Throne and City, 144.
} 
For Fokkelman this is further highlighted by the treatment of women in 2 Sam $2: 1-5: 5$. He notes that the women are presented in three pairs, with the first pair (Ahinoam, Abigail) belonging to David who is on the rise and the final pair (Mephibosheth's nurse, the female porter at Ish-boshet's house) being associated with the house of Saul and its demise. In between these two pairs two more women (Rizpah, Michal) are mentioned who both originally belong to the house of Saul but are taken away, the first by Abner who will defect to David and the second by David himself. Hence Fokkelman concludes that their displacement is used "as a metonym for the great about-turn" in the larger narrative. ${ }^{184}$

\section{Steven L. McKenzie}

Steven McKenzie's book entitled King David: A Biography deals with the story of David strictly from a historical perspective in an effort determine David's "real character and personality, physical appearance, deeds and accomplishments, and true motives and ambitions." 185 Of particular interest for the present study is chapter 6 entitled "Assassin David's Reign as King of Judah." As in all the other chapters of his book, McKenzie's analysis is based on the assumption that the portrait of David produced by historical analysis is very different from and much more realistic than the one presented in the biblical text itself. Though the Bible makes it appear as if David "did not seek the throne but had it thrust under him," McKenzie argues that "the historical David no doubt

\footnotetext{
${ }^{184}$ Fokkelman, Throne and City, 146.

${ }^{185}$ McKenzie, King David, 6.
} 
actively pursued kingship." "186 Like Vanderkam, he believes that the figures given for the reigns of David and Ish-boshet in 2 Sam 2:10-11 indicate that David was already king at Hebron during the last five and a half years of Saul's reign. ${ }^{187}$ In order to get rid of Saul and his sons, David entered into a coalition with the Philistines, which meant that he was involved in the planning of the battle at Gilboa and possibly even fought against Saul and his sons. ${ }^{188}$ Once Saul was out of the way, "David's aggression spurred by his ambition to annex Israel," caused him to provoke the civil war in 2 Sam $2-4$ through his letter to the men of Jabesh-Gilead and the treaty he established with the king of Geshur through his marriage to Maacah, the daughter of the king of Geshur. ${ }^{189}$ In order to solidify his claim to the throne, David had Michal taken away from her original husband Paltiel. Because of the apologetic nature of the material, the earlier story of David's marriage to Michael must be considered a fabrication. ${ }^{190}$

With regard to Abner's death, McKenzie proposes that 2 Sam $2-3$ contains two important background stories, namely the account of the first battle of the civil war in 2 Sam 2:12-32 and the confrontation between Ish-boshet and Abner in 2 Sam 3:6-11. Both

\footnotetext{
${ }^{186}$ McKenzie, King David, 113. In McKenzie's view, there were at least six carefully calculated steps that were designed to bring David to power: (1) David became the leader of a raiding band of outlaws in the Judean desert, (2) he served the Philistines as a mercenary, (3) he married Ahinoam of Jezreel, who may have been Saul's wife, (4) he became chief of the Calebites by having "Nabal" killed and marrying Abigail, (5) he sent gifts from his raids to the elders of Judah, and (6) he was anointed "king" by the elders of Judah in recognition of his de facto control. (McKenzie, 113-15)

${ }^{187}$ McKenzie, King David, 116.

${ }^{188}$ McKenzie, King David, 116.

${ }^{189}$ McKenzie, King David, 117, 123-24.

${ }^{190}$ McKenzie, King David, 119.
} 
scenes are "historically suspect" for McKenzie. ${ }^{191}$ After all, how could the biblical writer have known the private conversations between Abner and Asahel and between Abner and Ish-boshet? Other problems are that the portrait of Asahel stands in tension with his inclusion in the list of David's mighty men given in 2 Sam 23:18-19 and that Ishbaal's accusation and Abner's actions in chapter 3 are "somewhat hard to believe", since it would have been "very foolish of Ishbaal to accuse Abner of treason knowing that he actually controlled the power of the kingship."192

In reality, Abner did not initiate negotiations with David; it was David who lured Abner to Jerusalem to have him assassinated. ${ }^{193}$ David's complicity in the matter must already be suspected based on the fervency with which the narrator asserts his innocence. In addition, David had good reasons to get rid of Abner. While Joab was the one who actually killed Abner, he was only acting on orders from David. In order to clear David from any involvement in the matter, the author invented the story of Asahel's death at the hands of Abner, thus making it appear as if Joab had a personal motive for killing Abner. ${ }^{194}$ In reality, however, David was responsible for the murder. McKenzie sees further support for this conclusion in the fact that David does not punish Joab as well as in the similarities between Abner's death and the deaths of Nabal and Saul. In each case “a prominent person...dies under questionable circumstances and David's career benefits

${ }^{191}$ McKenzie, King David, 118, 121.

${ }^{192}$ McKenzie, King David, 118.

${ }^{193}$ McKenzie, King David, 118.

${ }^{194}$ McKenzie, King David, 120-21. 
enormously." 195 According to McKenzie, there is even a clear connection between the deaths of Nabal and Abner in 3:33 through the term "fool." This makes it likely that Nabal was murdered as well. In both cases David must be considered "a prime suspect." 196

McKenzie also finds it difficult to believe that David was completely uninvolved in the assassination of Ish-boshet. Not only was the incriminating evidence, namely Ishboshet's head, brought to David, but Ish-boshet's death again greatly benefitted David, since it removed the final obstacle on David's way to the throne of Israel. ${ }^{197}$

For McKenzie, David therefore was "a shrewd politician" who maneuvered his way first to the throne of Judah and then to the throne of Israel. In the end, the elders of Israel really had no choice but to anoint him as king over Israel. ${ }^{198}$

\section{Baruch Halpern}

An even more negative portrait of David is presented in Baruch Halpern's book David's Secret Demons: Messiah, Murderer, Traitor, King published in 2001. As Halpern states in the preface to his book, his aim is to "escape the framework of the historical narrative" about David as it is found in the Samuel books and instead to "imagine the events from a political and ideological position opposite that of the text."199

${ }^{195}$ McKenzie, King David, 121.

${ }^{196}$ McKenzie, King David, 122.

${ }^{197}$ McKenzie, King David, 125-26.

${ }^{198}$ McKenzie, King David, 126-27: “The Israelite elders' anointing of David was as much a capitulation to his de facto power and position as it was an invitation for him to lead."

${ }^{199}$ Halpern, David's Secret Demons, xv. 
Halpern thus attempts to view David as his enemies saw him. For Halpern this is the only way to discover the real David, since the David presented in the books of Samuel is "a ruler altogether too good to be true" who therefore never existed. ${ }^{200}$

The part of Halpern's book that is relevant to the present study is chapter 4, entitled "King David, Serial Killer", in which nine killings in the Samuel books are examined in order to determine whether David was responsible for them or not. ${ }^{201}$ Given the title of the chapter, it is not surprising that Halpern concludes that David was most likely culpable of all nine murders, even if he did not actually commit them himself. With regard to Ishbaal's death, Halpern proposes that David probably commissioned the killers, since they belonged to the Gibeonites, who were David's allies. After they had completed their mission, David had them executed to silence any accusations that he was involved in the murder. ${ }^{202}$ Concerning the death of Abner, Halpern contends that it is "very easy to imagine" that David employed a similar tactic as Absalom later did with Amnon, namely luring the other party into believing that peace had been made only to then turn on them and kill them. ${ }^{203}$ In Halpern's view, David promised to submit to Ishbaal on the condition that he be allowed to marry Ishbaal's sister Michal. This would explain why Ishbaal acquiesced to David's request. In response to David's promise of

${ }^{200}$ Halpern, David's Secret Demons, xvi.

${ }^{201}$ The nine killings are: (1) Nabal (1 Sam 25), (2) Saul and his sons (1 Sam 31), (3) Ishbaal (2 Sam 4), (4) Abner (2 Sam 3), (5) Saul's other descendants (2 Sam 21), (6) Amnon (2 Sam 13), (7) Absalom (2 Sam 18), (8) Amasa (2 Sam 20), and (9) Uriah (2 Sam 12).

${ }^{202}$ Halpern, David's Secret Demons, 82.

${ }^{203}$ Halpern, David's Secret Demons, 83. 
submission Abner and his delegation were dispatched to David at Hebron. ${ }^{204}$ The rest of the story then took place as described in the biblical account.

At the end of his book Halpern concludes:

The preceding investigations indicate that David's enemies regarded him as a nonIsraelite. Specifically, they thought of him as the Gibeonite agent of Philistine masters. They accused him of importing a foreign icon, the ark, as his state symbol. He consistently allied with foreign powers to suppress the Israelites whom he dominated. He spent most of his career as a brigand-king, and where he ruled, he did so by employing murder and mayhem as tools of state-craft. In fact, the only murder in the books of Samuel of which he was probably innocent is the one murder of which he stands accused in the apology. His enemies considered him a mass murderer. ${ }^{205}$

\section{Klaus-Peter Adam}

Klaus-Peter Adam's book Saul und David in der judäischen

Geschichtsschreibung is a revised version of his postdoctoral thesis at the PhilippsUniversität Marburg. Working backwards through 1 Sam 16-2 Sam 5, Adam examines the characters, themes, motifs and plot of the narratives about Saul and David in an effort to determine the development of the individual sections in this part of the Samuel books. With regard to 2 Sam $2-4$, he postulates that the unit developed from a report about an Israelite-Judean war at Gibeon $(2: 12-17,25-30,31,32 b ; 3: 1,6 a)$ to which a narrative about Abner's rebellion against Ishbaal and about the deaths of Abner and Ishbaal (3:6b11, 12-21, 22-27aba, 31-38; 4:1-5, 7-8a) was added. Later, those sections dealing with the issue of bloodguilt in the context of homicide were inserted $(2: 18-24,30 \mathrm{~b}, 32 \mathrm{a}$;

\footnotetext{
${ }^{204}$ Halpern, David's Secret Demons, 84.

${ }^{205}$ Halpern, David's Secret Demons, 479.
} 
$3: 27 b \beta, 28-30,39 ; 4: 6,8 b-12 a) .{ }^{206}$ Finally, the three short sections in $2: 1-11$ (which developed from 2:11) were prefixed to $2: 4-4: 12 .^{207}$

Throughout 1 Sam 16-2 Sam 5 Adam notes linguistic and thematic connections to later narratives in Kings and Chronicles, leading him to conclude that the conflict between Saul and David mirrors the later tensions between Israel and Judah. ${ }^{208}$ Written from a pro-Judean perspective, the narratives about Saul and David thus portray "als paradigmatisches Vorzeitgeschehen das Scheitern des israelitischen Reiches und Bedrohung, Verschonung, Vernichtung und Überleben Judas“ ${ }^{\text {. }}{ }^{209}$ Likewise, the story of Ish-boshet developed as „Vorgeschichte der israelitischen Königsgeschichte“, foreshadowing the rebellion against and the loss of royal power to usurpers described in $1 \mathrm{Ki} 15: 7$ and $16: 9 .^{210}$

John Van Seters

In his book The Biblical Saga of King David John Van Seters offers a detailed literary analysis of the story of David in 1 Sam $16-1$ Ki 2 (excluding 2 Sam $21-24){ }^{211}$ He argues that in these chapters are "two extensive and competing presentations of David" that are "obviously contradictory in the sense that one idealizes David as the

${ }^{206}$ Adam, Saul und David, 60.

${ }^{207}$ Adam, Saul und David, 56.

${ }^{208}$ Adam, Saul und David, 95.

${ }^{209}$ Adam, Saul und David, 213.

${ }^{210}$ Adam, Saul und David, 57.

${ }^{211}$ John Van Seters, The Biblical Saga of King David (Winona Lake, IN: Eisenbrauns, 2009). 
model king for all future monarchs,... and the other regards both David's rise to the throne and the manner of his reign as typical of oriental despots and hardly a fitting model for a just society." ${ }^{212}$ The earlier, idealized version composed by the Deuteronomistic Historian was taken up in the late Persian period by an author who expanded it with invented episodes in order to provide a more realistic portrait of David which reveals that he and his descendants were unfit to rule. While Van Seters classifies the earlier Deuteronomistic version as historiography, he argues that the later revision is a saga "in the specific meaning of the Icelandic and Norse sagas." 213

At the beginning of chapters 6 and 7 of his book, Van Seters discusses 2 Sam 2:1—5:5. In his view, the bulk of this section, namely 2 Sam $2: 4-4: 12$, was added by the later author, with only 2 Sam 2:1-2a, 3 and 5:1-2, $3 \mathrm{~b}$ belonging to the original Deuteronomistic account. ${ }^{214}$ 2:2b and 5:3a, 5 are small additions that integrate the David Saga into the Deuteroromistic account, while 5:4 could belong to either version. ${ }^{215}$ The Deuteronomistic account therefore only knows of David as king over all Israel, while in the David Saga David is anointed king of Judah first and then engages in a civil war with an invented son of Saul called Ish-boshet. ${ }^{216}$

With regard to David's message to the men of Jabesh-Gilead, Van Seters believes that David is here trying to win some of the Israelites to his side by way of flattery and

\footnotetext{
${ }^{212}$ Van Seters, The Biblical Saga, 1.

${ }^{213}$ Van Seters, The Biblical Saga, 42.

${ }^{214}$ Van Seters, The Biblical Saga, 362-63.

${ }^{215}$ Van Seters, The Biblical Saga, 263, 214.

${ }^{216}$ Van Seters, The Biblical Saga, 270-71.
} 
diplomacy. He wonders whether the episode is "intended to be deliberately ironic" since 2 Sam 10 reveals that David was on friendly terms with Nahash, the king of Ammon, who was the archenemy of Jabesh-Gilead. ${ }^{217}$ In his view, the list of regions in 2:9 is "a completely artificial reconstruction" and therefore cannot be taken seriously from a historical perspective. ${ }^{218}$ The same goes for much of the rest of chapter 2. Both the contest in 2:12-16 as well as the fact that the event is followed by an etiology is "typical of sagas," while the battle account including Asahal's pursuit of Abner cannot be considered "a realistic episode". ${ }^{219}$ Instead, the scene has been included solely for dramatic effect and continuity. The temporary truce in 2:24-28 is another "typical literary device of the saga." 220

Van Seters notes further parallels to the Nordic sagas in $2 \mathrm{Sam} 3$, such as the list of David's sons that interrupts the action in 3:2-5, the quarrel over a faux pas with a woman in 3:6-8 and the feast in 3:20.221 He claims that both Abner's reference to a divine oath in 3:9-10 and David's demand that Michal be returned to him in 3:13 are entirely political moves. ${ }^{222}$ According to Van Seters, both David and Abner would benefit from the deal they seek to make, since David would become king of both Judah and Israel and Abner "of course....would replace Joab as the commander of the forces of both

\footnotetext{
${ }^{217}$ Van Seters, The Biblical Saga, 271.

${ }^{218}$ Van Seters, The Biblical Saga, 272.

${ }^{219}$ Van Seters, The Biblical Saga, 272-73.

${ }^{220}$ Van Seters, The Biblical Saga, 273.

${ }^{221}$ Van Seters, The Biblical Saga, 274-75.

${ }^{222}$ Van Seters, The Biblical Saga, 275.
} 
regions." ${ }^{223}$ When Joab murders Abner, he therefore does so not only to avenge his brother's death, but also to save his own position. ${ }^{224}$ David's public demonstration of grief at Abner's funeral, on the other hand, cannot be interpreted as a "cover-up for a crime that he himself instigated." 225 According to Van Seters, such a reading is only possible if the text is reporting on an actual event. However, since the story is fiction, readers must accept whatever the author tells them about David's involvement in Abner's death as "his story." 226 With regard to the death of Ish-boshet, Van Seters claims that though the author does not suggest that David had a part in the assassination, he "nevertheless, leaves the quite-distinct impression that all of this show of outrage and honor given to Ish-boshet is merely for political purposes."227

In his comments on 2 Sam 5:1-5 Van Seters focuses on the differences between the Deuteronomistic account and the David Saga. While in the former all the tribes of Israel anoint David at Hebron immediately following the death of Saul (v. 1), in the latter the elders of Israel make a covenant with David sometime after the death of Abner (v. 3). And while in the Deuteronomistic account David is king over Israel for 40 years as stated in $1 \mathrm{Ki}$ 2:11, in the David Saga David only reigns over all Israel for 33 years (2 Sam 5:5). Van Seters thus concludes that there is "an entirely different conception of the Davidic kingship, in terms of both its legitimacy and its nature, between Dtr and the David Saga.

\footnotetext{
${ }^{223}$ Van Seters, The Biblical Saga, 275.

${ }^{224}$ Van Seters, The Biblical Saga, 276.

${ }^{225}$ Van Seters, The Biblical Saga, 276.

${ }^{226}$ Van Seters, The Biblical Saga, 276.

${ }^{227}$ Van Seters, The Biblical Saga, 277.
} 
The one rests on the divine right of kingship, the other on power and political arrangement."228

\section{J. Randall Short}

In his book The Surprising Election and Confirmation of King David J. Randall Short argues against the assertion made by a number of scholars that the so-called History of David's rise in 1 Sam 16-2 Sam 5 should be interpreted as an apology of David due to similarities to the Hititte "Apology of Hुattušili," proposing instead that the story "is best understood... as dramatically representing to YHWH's covenant-community His mysteriously and wonderfully surprising election and confirmation of 'the least' as YHWH's beloved." 229 Of particular interest for the present study are chapters 2 and 3 of Short's book, where he first demonstrates that both formally and thematically the biblical story has less in common with the Hittite apology than has been asserted. ${ }^{230}$ He then goes on to show that those who view the history of David's rise as an apology do so based on "certain predetermined assumptions" about the historical reality behind the text, one of which is "that David aspired to be king and was determined to do what was necessary to attain the throne." 231 According to Short, however, a close reading of the text suggests that "the thrust of HDR's account and of the present biblical account even more so...is that it is first and foremost YHWH who aspires, and acts providentially, to seat David on

\footnotetext{
${ }^{228}$ Van Seters, The Biblical Saga, 277.

${ }^{229}$ Short, Surprising Election, 5.

${ }^{230}$ Short, Surprising Election, 51-98.

${ }^{231}$ Short, Surprising Election, 129, 122.
} 
the throne." 232 Thus he demonstrates that there are "other equally plausible and sensible explanations of how this particular story of David's election and confirmation...might have been recounted and transmitted towards other ends", making the charge that David had his hands in the deaths of Abner and Ish-boshet far less compelling. ${ }^{233}$

\section{Cephas T.A. Tushima}

One of the most recent studies on the David narrative is Cephas Tushima's book The Fate of Saul's Progeny in the Reign of David published in 2011. The main focus of Tushima's study is the relationship between David and Saul's descendants in light of the concept of justice found in the book of Deuteronomy. ${ }^{234}$ Based on his close reading of 1 Sam 18:17-19:17; 25:39-44; 2 Sam 2-4, 6, 9, 16:1-4; 19:25-31 and 21:1-14 using the narrative critical method, Tushima concludes "that David, like other ancient Near Easter usurpers, perpetrated heinous injustices against the vanquished house of Saul" and "brazenly violated provisions in the Deuteronomic Code that guarantee justice for everyone in the covenant community." 235

Of particular interest for our study is Tushima's examination of 2 Sam $2-4$ in chapter 4 of his book. In his view, these chapters (as well as 2 Sam 5) constitute the last of three parts that make up the story of David's rise (HDR). ${ }^{236}$ Just like the rest of the

${ }^{232}$ Short, Surprising Election, 122.

${ }^{233}$ Short, Surprising Election, 128.

${ }^{234}$ Tushima, Fate of Saul's Progeny, xi.

${ }^{235}$ Tushima, Fate of Saul's Progeny, xi, 317. 2 Sam 1.

${ }^{236}$ Tushima, Fate of Saul's Progeny, 111. The first two parts are 1 Sam 16-18 and 1 Sam 19- 
HDR, this final section functions as an apology for David, written by an author who was "naively enthusiastic about David and relentlessly polemical against Saul."237 Therefore, the unusually passive depiction of David in these chapters cannot be taken at face value. Instead, Tushima contends that a close reading of the text shows that just like Abner, Joab and the sons of Rimmon, David was a "ferociously ambitious and avaricious" individual who sought to grasp the throne of Israel. ${ }^{238}$ That he successfully achieved this goal was the result of a number of shrewd political moves on his part. First, he remained a Philistine vassal during his reign over Judah, making it possible for him to move to Hebron without having to fear repercussions from the Philistines. ${ }^{239}$ Second, his marriages to Ahinoam and Abigail, both prominent women from the southern tribes, provided him with ties to both Hebron and Jezreel, giving him a power base in Judah. ${ }^{240}$ Third, he sought to gain the support of the men of Jabesh-Gilead, who were "the most vibrant force to be reckoned with amongst the northerners." ${ }^{241}$ Fourth, his marriages to foreign women like Maacah, provided him with alliances that posed a further threat to Ish-boshet's kingdom. ${ }^{242}$ Fifth, he asserted his power over both Abner and Ish-boshet, by demanding that Michal be returned to him as a condition for entering into a covenant

\footnotetext{
${ }^{237}$ Tushima, Fate of Saul's Progeny, 114.

${ }^{238}$ Tushima, Fate of Saul's Progeny, 114.

${ }^{239}$ Tushima, Fate of Saul's Progeny, 120.

${ }^{240}$ Tushima, Fate of Saul's Progeny, 118-119.

${ }^{241}$ Tushima, Fate of Saul's Progeny, 120.

${ }^{242}$ Tushima, Fate of Saul's Progeny, 132.
} 
with Abner. ${ }^{243}$ Furthermore, Tushima suggests that David may very well have had a hand in the death of Abner, since, in contrast to 2 Sam 1 and 4, where he had the killers executed, in this case "all he could do was to assert his innocence and resort to the pronouncement of invectives on Joab." 244 The narrator's comment that David did not know of what Joab did is "suspect" in light of the fact that Joab directly confronted David concerning Abner. ${ }^{245}$ With regard to the assassination of Ish-boshet, on the other hand, Tushima argues that a close reading of the text suggests that the brothers of Rimmon were opportunists who acted independently, making it unlikely that David was involved. ${ }^{246}$

In contrast to all the ambitious characters like David, Abner, Joab and the sons of Rimmon stands Ish-boshet "who manifests no ounce of ambition" and sadly "becomes the sacrificial lamb to service the ambitions of these others, especially David."247 Tushima agrees with Anderson's conclusion that Ish-boshet was probably younger than forty as 2 Sam 2:10 claims, since Ish-boshet failed to inherit his father's concubine Rizpah and was "taken" by Abner and "brought over" to Mahanaim, which would "fit more the profile of a youngster than of a forty-year-old man." ${ }^{248}$ In his view, the forty years in 2:10 may thus be a scribal error. Tushima also appears to favor Vanderkam's

\footnotetext{
${ }^{243}$ Tushima, Fate of Saul's Progeny, 135-38.

${ }^{244}$ Tushima, Fate of Saul's Progeny, 141.

${ }^{245}$ Tushima, Fate of Saul's Progeny, 140.

${ }^{246}$ Tushima, Fate of Saul's Progeny, 157.

${ }^{247}$ Tushima, Fate of Saul's Progeny, 114.

${ }^{248}$ Tushima, Fate of Saul's Progeny, 124.
} 
view that Ish-boshet's reign began right after Saul's death and coincided with the last two years of David's reign at Hebron. This would mean that David became king at Hebron before Saul's death and that he "did so in conscious opposition to Saul, indeed, at his personal expense. $^{249}$

Throughout the chapter Tushima also comments on literary aspects of the text and how they communicate "the ethos and pathos of the stories." ${ }^{250}$ Thus he notes the "skillful crafting" of the message David sent to the Jabesh-Gileadites in 2 Sam 2:5-7 which he sees as being "set to a threefold parallelism," 251 as well as the skillful way the author arranged the speeches of Abner and David in 2 Sam 3:12-13. ${ }^{252}$ He further calls attention to various repetitions throughout the narrative in 2 Sam 3:6-39 such as the leitwort שלח in vv. 12-16 or the similarities between the oaths of Abner and David in vv. 9-10 and 35 that signal to the reader the intertwining fates of the two men. ${ }^{253}$ In the same narrative he also notes the repeated appearance of the motif of "what is good in the eyes of" a person, which he interprets as a narrative echo by which the author seeks to compare that time in Israelite history with the time of the Judges when "everyone did what was right in his own eyes." 254 With regard to 2 Sam 4 Tushima points out how the record of Ish-boshet's murder in vv. 5-7 is organized in two parallel panels consisting of

\footnotetext{
${ }^{249}$ Tushima, Fate of Saul's Progeny, 125-26.

${ }^{250}$ Tushima, Fate of Saul's Progeny, 158.

${ }^{251}$ Tushima, Fate of Saul's Progeny, 121-23.

${ }^{252}$ Tushima, Fate of Saul's Progeny, 134-37.

${ }^{253}$ Tushima, Fate of Saul's Progeny, 134, 143-44.

${ }^{254}$ Tushima, Fate of Saul's Progeny, 138-39.
} 
vv. 5-6 and v. 7, respectively. The skillful use of repetition in this section serves to both focalize and emphasize certain elements and "affords the reader the vividness that is comparable to motion pictures." 255

\section{Summary}

The above review of literature has revealed that the majority of the examined studies have focused mainly on redactional and/or historical issues in 2 Sam 2:1-5:5, with the purpose of demonstrating the ideological coloring of the David narrative which most believe to have been intentionally designed as an apology of David. By comparison, much less attention has been given to a careful and in-depth exegesis of the text of 2 Sam 2:1-5:5 in its final form. Though a few studies have examined this part of 2 Samuel from a literary perspective, none of them have dealt exclusively with 2 Sam 2:1-5:5 or with the specific issue of the nature of David's kingship in this literary unit. There thus remains room for a careful analysis of this part of the David narrative for the purpose of ascertaining the nature of David's kingship as it is presented in 2 Sam 2:1-5:5. Such a close reading may also provide further insight into the portrait of David and thus help to clarify whether he is indeed presented in a purely positive light as many contend. In this way the present study may also help to determine whether or not there is any textual support for the claim that the David narrative was designed to function as an apology of David and his kingship.

\footnotetext{
${ }^{255}$ Tushima, Fate of Saul's Progeny, 151-53.
} 
CHAPTER 2

EXEGESIS OF 2 SAMUEL 2

\section{Samuel 2:1-11}

Text

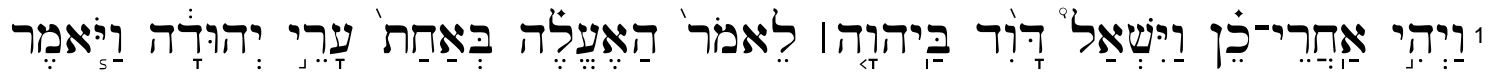

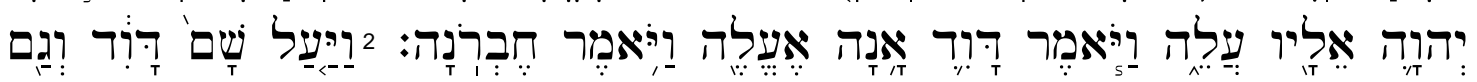

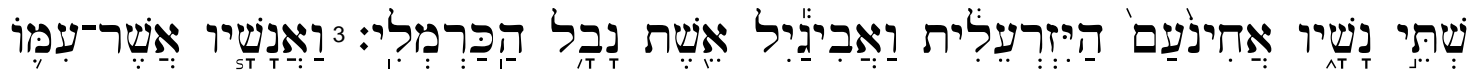

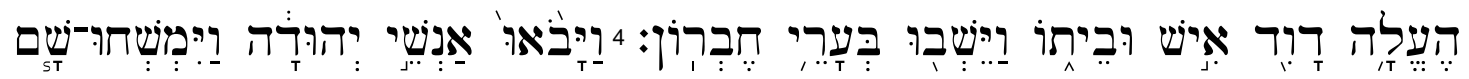

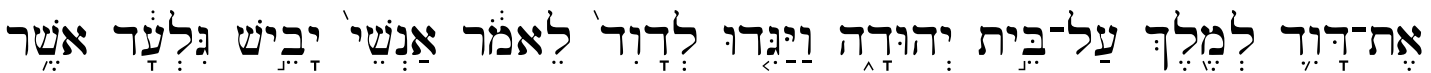

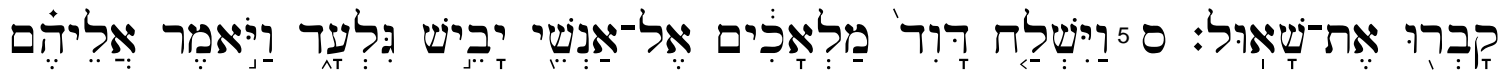

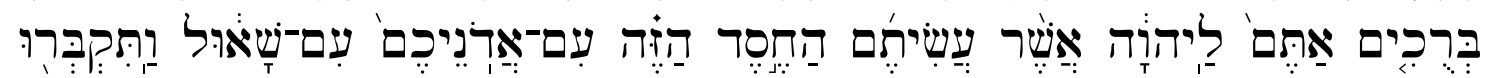

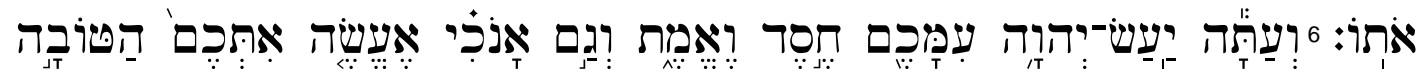

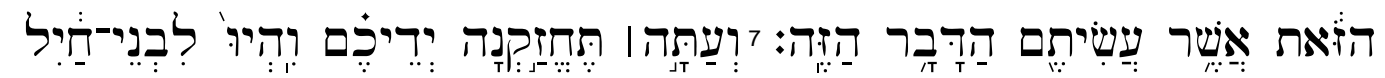

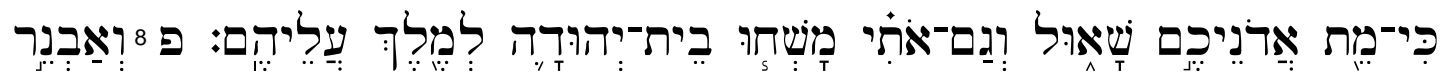

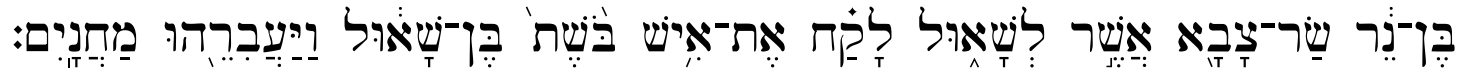

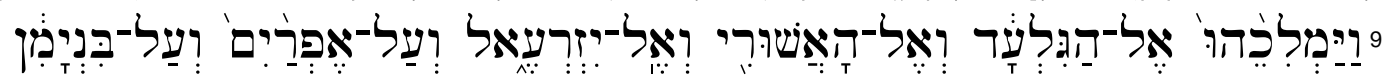

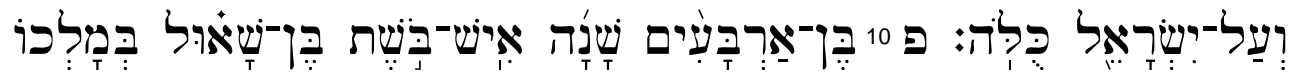

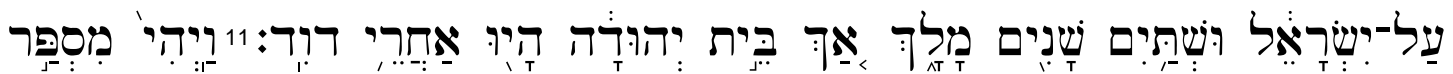

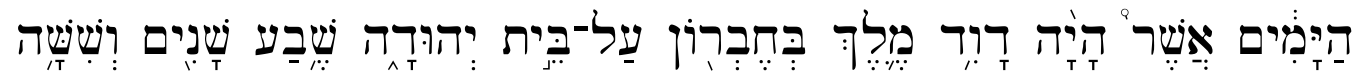
0: 
${ }^{1}$ Then it came to pass after this that David inquired of YHWH, saying: Shall I go up to one of the cities of Judah? And YHWH said to him: Go up. So David said: To where shall I go up? And he said: To Hebron. ${ }^{2}$ So David went up there and his two wives also, Ahinoam the Jezreelitess, and Abigail the wife of Nabal the Carmelite. ${ }^{3}$ And David brought up his men who were with him, every man and his household. And they dwelled in the cities of Hebron. ${ }^{4}$ Then the men of Judah came and there anointed David king over the house of Judah. When they told David, saying: It was the men of Jabesh-Gilead who buried Saul, ${ }^{5}$ David sent messengers to the men of Jabesh-Gilead and said to them: May you be blessed of YHWH because you showed this lovingkindness to your lord, to Saul, and buried him. ${ }^{6}$ And now may YHWH show lovingkindness and faithfulness to you and I also, I will do this good to you, because you did this thing. ${ }^{7}$ And now let your hands be strong and be valiant for your lord Saul is dead and also, the house of Judah has anointed me king over them. ${ }^{8}$ But Abner, the son of Ner, commander of Saul's army, took Ishboshet, the son of Saul, and brought him over to Mahanaim ${ }^{9}$ and made him king over Gilead, and over the Ashurites, and over Jezreel, and over Ephraim, and over Benjamin, and over all Israel. ${ }^{10}$ Ish-boshet, the son of Saul, was forty years old when he became king over Israel and he was king for two years. Only the house of Judah followed David. ${ }^{11}$ And it came to pass that the number of days that David was king in Hebron over the house of Judah was seven years and six months.

\section{Delimitation}

There seems to be general agreement among commentators that 2 Sam 2:1 marks the beginning of a new literary unit and - on a larger scale - a new phase in the life of David and in the history of Israel. ${ }^{1}$ That a shift takes place in the story at this point is indicated not only by the switch from poetry back to prose as well as by the introductory

${ }^{1}$ See e.g. J. Robert Vannoy, 1-2 Samuel, CBibC 4a. (Carol Stream, IL: Tyndale House Publishers, 2009), 272; Bill T. Arnold, 1 \& 2 Samuel, NIVAC 7 (Grand Rapids, MI: Zondervan, 2003), 418; Robert D. Bergen, 1,2 Samuel, NAC 7 (Nashville, TN: B\&H Publishing, 1996), 296. Fokkelman even goes so far as to suggest that 2 Sam 1:1-11 is "the true beginning of II Samuel." (Fokkelman, Throne and City, 25) 
phrase in $2: 1,{ }^{2}$ but also by the fact that in a sense David's lament at the end of 2 Sam 1 functions as the true conclusion of the account of Saul's kingship. Thus one phase of the story told in 1-2 Samuel draws to a close in 1:27 and another begins in $2: 1 .^{3}$

While the starting point of this literary unit is thus quite easily determined, it does not seem to be as readily apparent where the unit ends, as evidenced by the fact that at least three different endpoints have been suggested, namely v. 4a, v. 7 and v. 11. Those who favor the first option usually divide 2:1-11 into three separate units: vv. 1-4a, 4b-7 and $8-11 .^{4}$ While a case can be made for such a division based on the scene changes that take place in vv. $4 \mathrm{~b}$ and 8 , the main shortcoming of this view is that it fails to recognize the terminological, conceptual and structural connections between these three sections which suggest that they are intended to be viewed as one literary unit. As Fokkelman has noted, for example, vv. 4, 7 and 11 contain very similar statements about David being king over the house of Judah, suggesting that these verses all belong to the same literary

${ }^{2}$ Arnold A. Anderson, 2 Samuel, WBC 11 (Dallas, TX: Word, 1989), 22, recognizes the phrase as a "recurrent transition-marker." See also Arnold, 1 \& 2 Samuel, 419 and Craig Morrison, 2 Samuel, BerO (Collegeville, MN: Liturgical Press), 33.

${ }^{3} \mathrm{~A}$ different view is taken by Campbell who sees the first seven verses of chapter 2 as the conclusion of the first unit in 2 Samuel that begins in 1:1. Thus he divides 2 Sam $1-4$ into two units, namely $1: 1-2: 7$ and 2:8 - 4:12. In his view, the first unit describes David's kingship over Judah and demonstrates the innocence of David as well as his feelings regarding the deaths of Saul and Jonathan, while the second unit covers the civil war between David and Ish-boshet and shows David's innocence and feelings over the deaths of Abner and Ishbaal. See Antony F. Campbell, 2 Samuel, FOTL 8 (Grand Rapids, MI: Eerdmans, 2005), 16. While Campell's view certainly has some merit and must not be completely ruled out, the textual evidence presented in this study suggests that the main break in these chapters takes place at 2:1 instead of at 2:8.

${ }^{4}$ See e.g. Anderson, 2 Samuel, 20-37; Klaus vom Orde, Das zweite Buch Samuel, WS (Wuppertal, Germany: R. Brockhaus Verlag, 2002), 38-44; Mary J. Evans, 1 \& 2 Samuel, NIBCOT 6 (Peabody, MA: Hendrickson Publishers, 2000), 145-46. 
unit..$^{5}$ Other connections include the keyword אִיש that occurs in all three sections as well as the clearly intended comparison between David and Ish-boshet that is an issue throughout vv. 1-11, in particular in sections 1 and 3. In addition, as will be shown below, all three sections are also part of the same literary structure and are framed by statements about David beginning with וַירִירי in vv. 1 and 11.

These connections also call into question the view that this opening section of 2 Sam 2 ends with v. $7 .^{6}$ Though v. 8 introduces Abner and Ish-bosheth and could thus be seen as the beginning of the civil war story that follows in vv. 12-32, the evidence presented above suggests that vv. 8-11 are more closely connected to vv. 1-7 than to vv. 12-32. This conclusion is further supported by the fact that vv. 12-32 exhibit a chiastic structure that is destroyed if the starting point of the unit is seen in v. $8 .^{7}$ Based on the textual evidence, it thus seems best to view the literary unit as extending all the way to $2: 11 .^{8}$

${ }^{5}$ Fokkelman, Throne and City, 25.

${ }^{6}$ Scholars who favor this option include Andrew Steinmann, 2 Samuel (St. Louis, MO: Concordia, 2017), 21-26; Vannoy, 1-2 Samuel, 272-74 and Arnold, 1 \& 2 Samuel, 418-35.

${ }^{7}$ Youngblood's chiastic structure, which includes vv. 8-11 and sets these verses parallel to vv. 2932, is not fully convincing. See Ronald F. Youngblood, "1 \& 2 Samuel," in The Expositors Bible Commentary, eds. Tremper Longman III and David E. Garland (Grand Rapids, MI: Zondervan, 2010), 3:822. While there are some general parallels between these sections such as the keywords "Mahanaim," "Hebron," "David," and "Abner," Youngblood's proposal fails to take into account the statement about David's kingship over Judah in v. 11 that strongly connects vv. 8-11 to vv. 1-7 as well as the "journey motif" that binds vv. 12-32 together. Whereas the two armies and their commanders depart from their respective home bases in vv. 12-13, they return there in vv. 29-32.

${ }^{8}$ This view is adopted, among others, by P. Kyle McCarter, II Samuel: A New Translation with Commentary, AB 9 (Garden City, NY: Doubleday, 1984), 80-90; Morrison, 2 Samuel, 33-38; Fokkelman, Throne and City, 25-39 and Bruce Birch, "The First and Second Books of Samuel," in The New Interpreter's Bible, ed. Leander E. Keck (Nashville, TN: Abingdon Press, 1998), 2:1210-1214. 


\section{Structure}

As already noted above, vv. 1-11 consist of three subsections (vv. 1-4a, 4b-7, 811) that each end with a statement about David being king over the house of Judah and

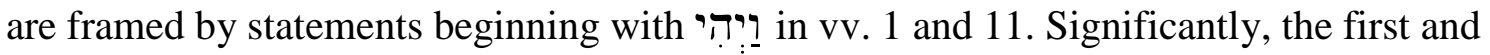
third sections are connected by a number of terminological and thematic parallels and contrasts. Thus both sections share no less than eight terms, four of which are only found

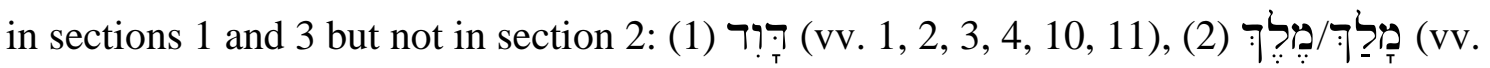

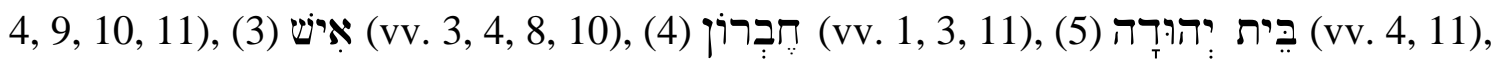

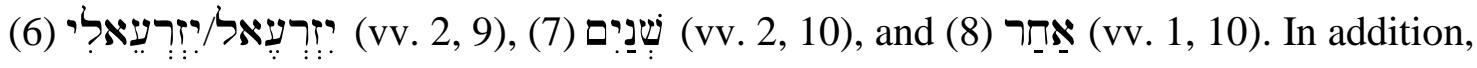
in both sections there is movement to a certain location followed by the coronation of a

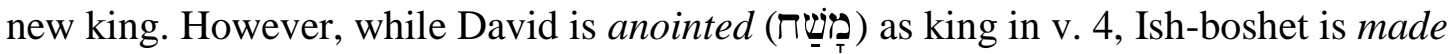
king (hiphil of מָז

(1) While David inquires of the Lord before moving to Hebron, no such inquiry is reported before Ish-boshet moves to Mahanaim.

(2) While David moves to Hebron with his wives and men, no wives or men are mentioned in connection with Ish-boshet.

(3) While David goes up (עָד (עָה ) to Hebron, Ish-boshet is brought (hiphil of over to Mahanaim.

(4) While David is anointed king only over the house of Judah, Ish-boshet is made king over all Israel.

These similarities and contrasts suggest that these sections are to be viewed as parallel outer elements of a chiastic structure that frame the central section in vv. $4 b-7$. In 
contrast to sections 1 and 3 which are mostly report, the central section "consists almost exclusively of the spoken word." ${ }^{\prime 9}$ It is further set apart from the outer sections by the

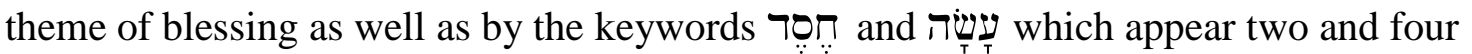
times respectively in vv. $4 \mathrm{~b}-7$ but not in vv. $1-4 \mathrm{a}$ and $8-11 .^{10}$

Thus, the structure of vv. 1-11 may be laid out as follows:

A David goes up to Hebron and is anointed king over the house of Judah; opens with רַיריחי statement regarding David in v. 1 (vv. 1-4a)

B David's message to the men of Jabesh-Gilead (vv. 4b-7)

A' Ish-boshet is brought to Mahanaim and made king over all Israel;

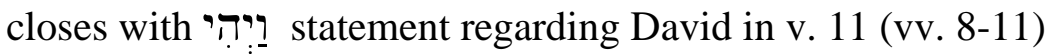

This arrangement highlights the central section which also seems to exhibit a concentric arrangement. Morrison, for example, has suggested the following structure which centers on David's wish that God show אְִּ: Gilead:

${ }^{9}$ Fokkelman, Throne and City, 40.

${ }^{10}$ Yet another contrast between the central and framing sections is suggested by Fokkelman who sees in these sections an ,undulating movement of life-death-life, inasmuch as A [section 1] and C [section 3] announce the coming to power of a new generation, whilst B [section 2] is a flashback to the death of Saul preconditional to David's coming to power." Fokkelman, Throne and City, 39-40. 
A David is anointed king over the house of Judah (2:4a)

B Saul is dead and buried $(2: 4 b)$

C The people of Jabesh-gilead were loyal to Saul (2:5)

D May God be loyal to them (2:6a)

C' David will be good to them $(2: 6 b)$

B' Saul is dead (2:7a)

$\mathrm{A}^{\prime}$ David has been anointed king over the house of Judah $(2: 7 \mathrm{~b})^{11}$

While Morrison's proposal is more thematic in nature and encompasses the entire central section in vv. 4b-7 plus v. 4a, the arrangement suggested by Fokkelman takes into account verbal repetitions and only includes David's message in vv. 5b-7. ${ }^{12}$ According to Fokkelman, the message is made up of three parallel parts that each consists of a wish or wishes followed by a conjunction and a clause giving the motivation for the wish(es):

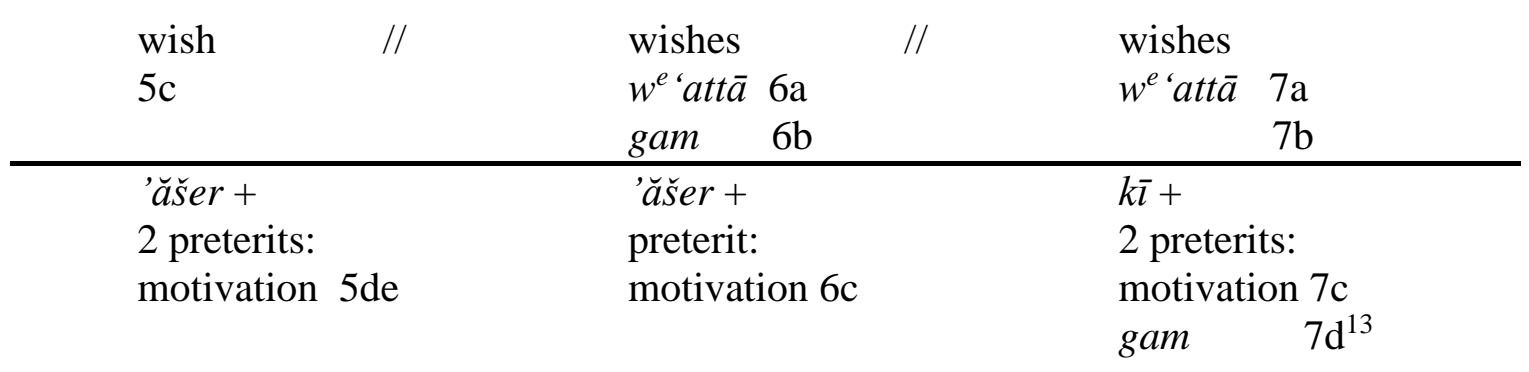

${ }^{11}$ Morrison, 2 Samuel, 34.

12 It might be argued that Morrison's proposal is weakened somewhat by the fact that he is only able to achieve this arrangement by including $\mathrm{v}$. $4 \mathrm{a}$ which seems to belong to section 1 , as shown above. If a less rigid view is taken, however, v. 4a could also be seen as a hinge statement that not only serves as the climactic conclusion of section 1 but also introduces the central section in vv. 4b-7. This is further supported by the fact that there is much less of a break between v. $4 \mathrm{a}$ and v. $4 \mathrm{~b}$ than between v. 7 and v. 8 , for example.

${ }^{13}$ Fokkelman, Throne and City, 31. 
Fokkelman's proposal confirms the central importance of v. $6 \mathrm{a}$, while at the same time suggesting that the structural center of the passage should be extended to include the second part of v. 6 as well. This is further supported by the fact that v. 6 is framed by two

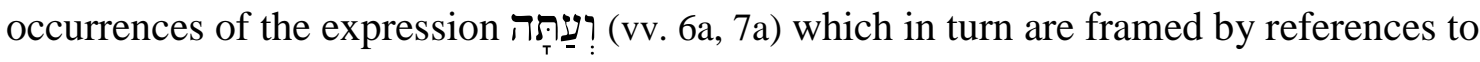
Saul as lord (אָרון) of the men of Jabesh-Gilead in vv. 5 and 7. That v. 6 takes a central position between v. 5 and v. 7 is also suggested by its transitional character in that it looks both backward (through the conjunction 'ăšser) to the first part of the message as well as forward (through the adverb $w^{e}$ att $\bar{a}$ ) to the third part. Thus, the two statements in v. 6 mark the turning point from what the men of Jabesh-Gilead did in the past to what David hopes they will do in the future. Significantly, these statements feature the three main protagonists of the central section (YHWH, David and the men of Jabesh-Gilead) in a relationship that is characterized by mutual אמקת חקֶ.: This kind of a relationship between God and man as well as between men then seems to be the main focus not only of the central section but of the entire literary unit.

It should also be noted that the central section is instructive for all of 2 Sam $2-4$ because it shows the ideal of people showing חֶֶֶ to one another and being shown by God in return. It is precisely the lack of most of the subsequent events in 2 Sam 2-4. The connection between the central section and those subsequent events is established through the keyword קָּ in 2:4, which also reminds the reader of the actual account of Saul's burial in 1 Sam 31:11-13. There the author mentions that the men of Jabesh-Gilead "walked all night" in order to take down the bodies of Saul and his sons from the wall of Beth-shan. Significantly, both the phrase 


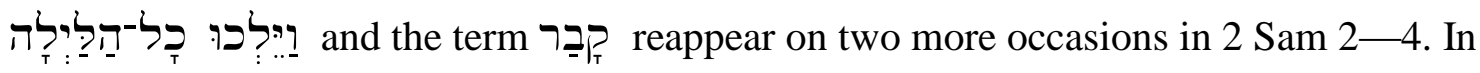
2 Sam 2 both Abner and Joab and their men walk all night (vv. 29 and 32) and Asahel is buried (v. 32) and in 2 Sam 4 the sons of Rimmon walk all night (v. 7) and Ish-boshet's head is buried (v. 12). These repetitions invite the reader to compare these two stories and in particular the lack of the men of Jabesh-Gilead and with David's response to the thus appears to intentionally mention David's interaction with the inhabitants of JabeshGilead at the beginning of chapters $2-4$ in order to present an ideal against which the actions of other characters must be evaluated.

At least two things are highlighted by the structure of vv. 1-11 that are relevant with regard to the nature of David's reign:

\section{The contrast between David and Ish-boshet, in particular with regard to the way} in which they become king. Whereas David inquires of YHWH before moving to Hebron where he is anointed king by a representative group, Ish-boshet is taken to Mahanaim and made king by a single individual without any consultation with YHWH. While David thus shows initiative in inquiring of $\mathrm{YHWH}$ and leading his men and their families up to Hebron, but at the same time does not take matters into his own hands, Ish-boshet is presented as a completely passive individual, who is acted upon by another who does not seek divine counsel, but seems bent on pursuing his own plans. ${ }^{14}$ From the very

\footnotetext{
${ }^{14}$ Since Abner is the active agent on Ish-boshet's side, it is also worthwhile to compare him with David. As Birch notes: "Abner takes, brings, and makes a king. He imposes authority and forces a political ideology on the land. David inquires of God, acts decisively himself, and submits to the anointing of the people. He is not without his own authority or influence of his own considerable will. But he is willing to submit his own authority to a partnership with God, on the one hand, and with the community on the other
} 
beginning, David is therefore presented as the more capable and godlier leader who does not seize the throne but patiently obtains it in the proper way with the blessing of YHWH and the people. ${ }^{15}$ His rise to kingship is portrayed as due to YHWH's guidance, while Ish-boshet's kingship is the result of human initiative. ${ }^{16}$

\section{The importance of David's message to the men of Jabesh-Gilead. By recording}

this message as David's first official act as king and placing it in the center of this opening literary unit, the author emphasizes not only David's respect for his enemy Saul, but also his respect for and goodwill toward those loyal to Saul. ${ }^{17}$ Thus David's kingship is from the very beginning associated with this attitude. Instead of harboring feelings of hatred toward and punishing those who ensured a proper burial for the man who sought his life for many years, David pronounces a blessing on them and commends them for the חֶֶֶ they showed to their lord. So important does this concept of newly anointed king, that at the very center of his message he expresses the wish for YHWH to show חֶֶֶ אמֶת to the men of Jabesh-Gilead in return and then promises to do the same to them. By repeatedly presenting this blessing as a reaction to what they did,

hand." (Birch, "First and Second Books of Samuel," 1213) Thus, David is presented as superior to both Abner and Ish-boshet.

${ }^{15}$ Robert B. Chisholm, $1 \& 2$ Samuel, TTC (Grand Rapids, MI: Baker Books, 2013), 200. The fact that no divine instructions are mentioned in connection with David's anointing in v. 4 does not mean that God did not approve of his kingship. It must be remembered that David had already been anointed at YHWH's bidding back in 1 Sam 16, which means that the anointing by the men of Judah in 2 Sam 2 in effect was only a recognition and confirmation of that earlier anointing. See Walter Brueggemann, First and Second Samuel, IBC (Louisville, KY: Westminster John Knox Press, 1990), 220 and Vannoy, 1-2 Sатиеl, 273.

${ }^{16}$ Anderson, 2 Samuel, 25. Campbell, 2 Samuel, 28: "Nothing is made explicit, but the association within the text gives the whole process the aura of YHWH's will." McCarter, II Samuel, 89, takes a similar view.

${ }^{17}$ McCarter, II Samuel, 90. 
the author also highlights the principle of repaying good with good, which is thus brought into close association with David's kingship as well. Instead of viewing the act of the men of Jabesh-Gilead as evil and responding with evil, David recognizes it as a good deed and responds in kind. From the outset, his kingship is therefore based on very positive attitudes and principles that serve as the foundation for a harmonious relationship with God and other human beings.

\section{Close Reading}

\section{Verses 1-4a}

Verse 1

It is not without significance that the account of David's kingship opens with the

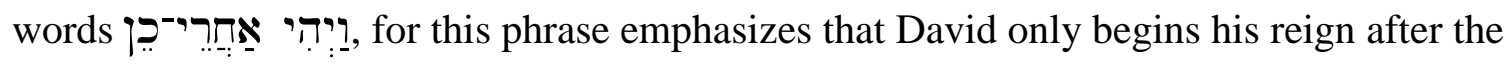
events recorded immediately prior to 2 Sam 2, namely (1) Saul's death (1 Sam 31), (2) David's execution of the Amalekite who claimed to kill Saul (2 Sam 1:1-16), and (3) David's lament for Saul and Jonathan (2 Sam 1:17-27). By explicitly noting that David's move to Hebron and his subsequent anointing as king over Judah took place after these events, the author presents David as one who does not seize the kingdom, but patiently waits for the proper time to receive it. Even after the death of Saul, David does not immediately take steps towards kingship, though he has the very real and tempting opportunity to crown himself king when the Amalekite brings him the crown and the bracelet of Saul. Instead, he has the messenger executed and mourns for the fallen king and his son, who naturally would have been Saul's successor and therefore a potential threat to David and his kingship. In this way David shows his great respect for Saul and 
his family and makes it clear that he rejects the idea of seizing the throne by violent means.

In light of this it is interesting that the only time the rare phrase occurs previously in 1-2 Samuel is in $1 \mathrm{Sam}$ 24:6, where David is conscious-stricken for having cut off a corner of Saul's robe. ${ }^{18}$ As scholars have recognized, this act of cutting Saul's robe is highly significant, since it symbolizes the transfer of kingship from Saul to David. This deeper meaning of David's act is suggested by the allusion in 1 Sam 24:5-6 to 1 Sam 15:27-28, where the transfer of the kingship from Saul to David is

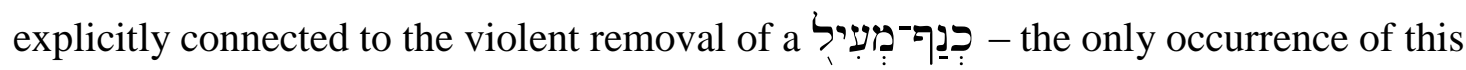
construct in the Old Testament prior to 1 Sam 24:5. ${ }^{19}$ Therefore, while David is unwilling to kill Saul, he does in essence symbolically invalidate Saul's claim to kingship. ${ }^{20}$ His reaction in v. 6 , however, shows that he considers even such a symbolic attack on the king to be a sin. ${ }^{21}$ By opening his account of David's reign in 2 Sam 2:1 with a subtle link back to this very verse, the author thus seems to remind the attentive reader of David's attitude towards both Saul and YHWH and his guilt over an act that could be interpreted as an attack on Saul's kingship. It is as if the author is saying: It is this man David, who

\footnotetext{
${ }^{18} \mathrm{As}$ will become evident below, this is the first of a number of terminological connections between this literary unit and 1 Sam 24 , increasing the likelihood that the author is intentionally alluding to this passage in 2 Sam 2:1-11.

${ }^{19}$ See e.g. Bergen, 1,2 Samuel, 239; Peter J. Leithart, A Son to Me: An Exposition of 1 \& 2 Samuel (Moscow, ID: Canon Press, 2003), 135.

${ }^{20}$ Bergen, 1,2 Samuel, 239: "By removing the corner of the robe, David made Saul's robe to be in a state of noncompliance with Torah requirements (cf. Num 15:38-39; Deut 22:12); thus, Saul's most obvious symbol of kingship was made unwearable."

${ }^{21}$ Leithart, A Son to $\mathrm{Me}, 135$.
} 
did not kill the one who sought his life and whose heart even struck him when he symbolically took the kingdom from Saul, who will now become king over Judah and eventually over all of Israel. At the same time, the link to 1 Sam 24 is noteworthy because at the end of that chapter even Saul himself recognized David as his successor and predicted that the kingdom would be established in his hand.

Yet even after the events of 2 Sam 1, David still does not seize the throne and proclaim himself king. Instead, his first recorded action in 2 Sam 2 is to inquire of YHWH. This is not surprising, since David has done so a number of times in the previous chapters. $^{22}$ This consistent inquiring suggests that David is highly interested in and keenly aware of his need for divine guidance. Thus, he does not simply move back into the land whenever he thinks best but only proceeds after ascertaining that such a move is in harmony with the will of God. This desire to be guided by YHWH and the fact that YHWH always answers him sets David apart from both Saul, who inquires of YHWH much less frequently and never receives an answer, and Saul's house in the person of Ishboshet and Abner, who do not communicate with YHWH at all. ${ }^{23}$

How serious David is about doing YHWH's will is revealed by the ensuing dialogue in the remainder of v. 1, for even when YHWH responds favorably to his inquiry whether he should go up to one of the cities of Judah, David is not satisfied but inquires further as to the exact place where he should go up to. That David is instructed to

${ }^{22}$ See 1 Sam 22:10, 13, 15;23:2, 4; 30:8.

${ }^{23}$ Morrison, 2 Samuel, 33. The only times Saul inquires of YHWH are in 1 Sam 14:37 and 1 Sam 28:6. In the first case, he does so only after the priest suggests it and in the second case his inquiry seems to be prompted solely by fear, rather than a true desire to know the will of YHWH. In both cases YHWH does not answer him. 
move to Hebron from his exile in Philistine territory is significant for it connects his experience with that of the patriarchs Abraham, Isaac and Jacob, all of whom left the land but eventually returned and dwelled at Hebron (Gen 13:18; 35:27). ${ }^{24}$ It was in this vicinity that the burial place at Machpelah was located, the only piece of land Abraham possessed in Canaan (Gen 23). As “the beginning of Abraham's inheritance of the land" and "one of the places where Abram set up an altar in his liturgical 'shadow conquest' of Canaan" Hebron was therefore from the very beginning closely associated with the conquest and possession of the land. ${ }^{25}$ This is further confirmed in Num 13, where the men sent to spy out the land go up (עיז ) where the sons of Judah go up (עָד דלה ) and conquer Hebron (Judg 1:4, 10-11, 20). The fact

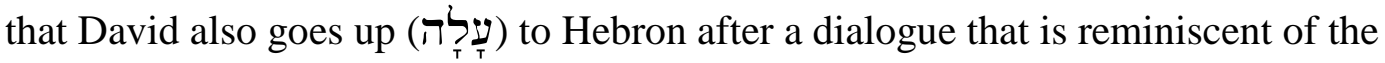
exchange between the sons of Israel and YHWH at the beginning of Judg 1 thus raises the possibility that he is recapitulating the experience of Israel and that his move to Hebron should be understood as initiating the completion of the conquest that Israel failed to accomplish centuries earlier. ${ }^{26}$ That this is indeed the case is confirmed both by the significant parallels between the stories of David and Israel that have been pointed out by Leithart as well as by the fact that it is from Hebron that David in 2 Sam 5 proceeds to

\footnotetext{
${ }^{24}$ Leithart, A Son to Me, 181.

${ }^{25}$ Leithart, A Son to Me, 181.

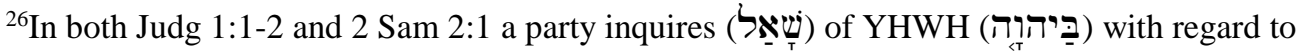

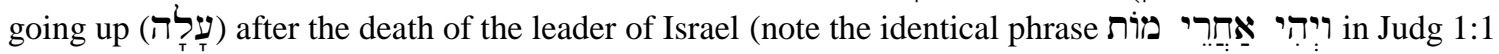
and 2 Sam 1:1), in both cases YHWH responds favorably and in both cases the tribe of Judah and the city of Hebron play a significant role in the subsequent narrative. 
conquer Jerusalem - one of the cities mentioned in Judg 1 that Israel failed to conquer. ${ }^{27}$

David's going up to Hebron therefore not only strengthens the impression that he is reliving the experience of the very nation he about to rule, but also seems to provide a first hint that his kingship is closely associated with the conquest and possession of Canaan so that Israel may dwell in peace. ${ }^{28}$

Verse 2

In obedience to the divine instructions, David goes up to Hebron, taking with him his two wives, Ahinoam, the Jezreelitess, and Abigail, the wife of Nabal, the Karmelite. While the move to Hebron associates David with all three patriarchs, the mention of two wives connects him specifically with Jacob. This is not surprising given the striking similarities between the stories of these two individuals noted by several commentators. ${ }^{29}$ Both are the youngest son (Gen 25:26; 1 Sam 16:11), both experience hostility from their brothers (Gen 27:41; 1 Sam 17:28), both leave their father's house and join a new household where they prosper and are offered the daughter of the father of the house that

\footnotetext{
${ }^{27}$ Like Israel, David is chosen by YHWH (Gen 12:1-3; Exod 19;5-6; 1 Sam 16:1-13), leaves the land because of a threat (Gen 46; 1 Sam 27), is received warmly by the ruler of a foreign nation and given a particular place to dwell (Gen 47:1-12; 1 Sam 27:3-7), is pursued by a king who wants to kill him (Exod 14; 1 Sam 20-27), spends time in the wilderness, where he is tempted and miraculously delivered by YHWH (Exod 14 - Num 21; 1 Sam 23-26), and eventually returns to the land he left years before (Josh 34; 2 Sam 2). Further parallels include the following: Both are opposed by Edomites (Num 20:14-21; 1 Sam 21:7, 22:11-19) and fight against Amalekites (Exod 17:8-16; 1 Sam 30:1-31), both are hungry but receive divine bread (Exod 16:1-21; 1 Sam 21:1-6) and both come in contact with people who refuse to give them bread and water (Deut 23:3-4; 1 Sam 25:11). See Leithart, A Son to Me, 123; 152; 175; 224; 252; 321.

${ }^{28}$ Even before he becomes king, David shows that he is aware of the need to finish the conquest and willing to play an active role in this endeavor. In contrast to Saul, who begins his reign as a new Joshua in 1 Sam 11 but quickly becomes a new Achan in 1 Sam 14 (note in particular the similarities between 1 Sam 14:38-45 and Josh 7:16-26 and the way the author subtly indicts Saul as the real culprit), thus preventing Israel from fully conquering the land, David consistently and successfully fights against Israel's enemies in 1 Samuel, even while he is in exile outside of the land (see 1 Sam 17-19; 23:5; 27:8-12; 30).

${ }^{29}$ See Leithart, A Son to Me, 102, 115, 119; Bergen, 1,2 Saтиеl, 203, 208.
} 
is then withdrawn, but eventually both become the son-in-law (Gen 28-30; 1 Sam 18).

Like Jacob, David escapes from his new home, is pursued by his father-in-law and now in 2 Sam 2 returns to the land with his two wives (Gen $31-32 ; 1$ Sam $19-2$ Sam 2). ${ }^{30}$

The fact that David has two wives like Jacob has both positive and negative implications. While on the one hand it suggests that David is a new patriarch who will build the house of Israel, on the other hand it is a first hint at the strife between brothers that will characterize both David's family as it did Jacob's as well as the tribes of Israel in the following narratives.

That the names of the wives are mentioned also seems to be significant in this particular context. Intriguingly, the only other Ahinoam mentioned in the OT is the wife of Saul, leading some scholars to suggest that the two are the same person. ${ }^{31}$ While this cannot be proven from the text, it is nevertheless interesting that David's wife has the same name as Saul's - especially since Ahinoam is first mentioned as David's wife at the end of 1 Sam 25, where David marries Abigail. As a number of scholars have pointed out, Abigail's husband Nabal appears to function as a stand-in for Saul. ${ }^{32}$ Thus David marries both a woman carrying the same name as Saul's wife and the wife of a man who is presented as Saul's alter ego. The fact that these marriages are first mentioned in 1 Sam

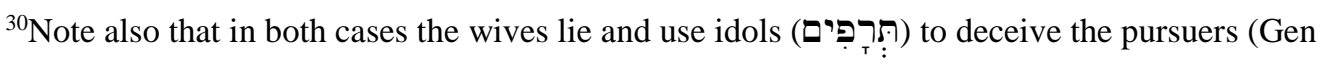
31:34-35; 1 Sam 19:13-17).

${ }^{31}$ See e.g. Jon Levenson, "1 Samuel 25 as Literature and History," Catholic Biblical Quarterly 40 (1978): 27; Heather R. McMurray, “Ahinoam,” NIDB 1:88.

${ }^{32}$ See e.g. Leithart, A Son to Me, 138; Johann W. H. van Wijk-Bos, Reading Samuel: A Literary and Theological Commentary (Macon, GA: Smyth \& Helwys Publishing, 2011), 137; Ellen van Wolde, "A Leader Led by a Lady: David and Abigail in 1 Samuel 25," Zeitschrift für die Altestamentliche Wissenschaft 114 (2002): 365-66. 
25 where, as in 1 Sam 24 and 26, the issue of David's succession of Saul as king is explicitly addressed, suggests that these marriages symbolically foreshadow that the kingdom will pass from David to Saul. The mention of the two wives in 2 Sam 2 thus appears to be yet another subtle reminder that David is the legitimate successor of Saul. ${ }^{33}$

\section{Verse 3}

David is accompanied to Hebron not only by his wives but also by his men and is thus "at the apex of a widening series: one man - two women - his men and their families." ${ }^{34}$ Whereas Saul and his sons are dead and the men of Israel have left the cities

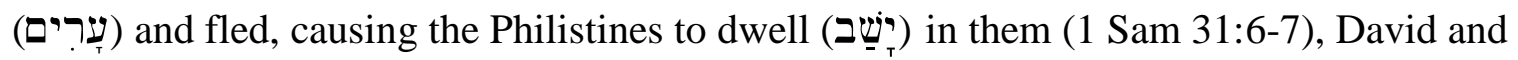

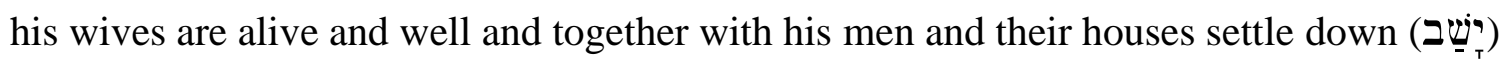

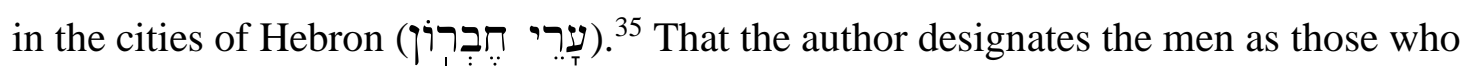
were with David and then states that every man went up with his house does not appear

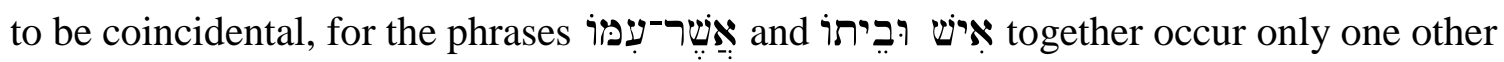
time in the Old Testament, namely in 1 Sam 27, where David leaves Israel and moves to Philistine territory. ${ }^{36}$ Just like in 2 Sam 2 he takes along his men as well as his two wives

${ }^{33}$ Note that David does not take Abigail away from Nabal by force, but invites her to be his wife after Nabal has died through divine intervention. Similarly, David does not take the kingdom from Saul by force, but waits until after Saul's death before making any move towards kingship.

${ }^{34}$ Fokkelman, Throne and City, 27.

${ }^{35}$ Fokkelman, Throne and City, 29. That David goes up (עיד

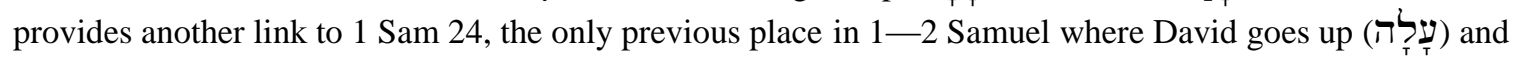

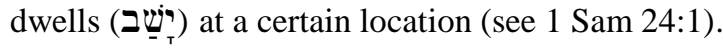

${ }^{36}$ Besides 1 Sam 24, 1 Sam 27 is also the only previous place where David goes up (עָד (עָדה) in $1-2$ Samuel (see 1 Sam 27:8). 
who are mentioned by name (1 Sam 27:3). In both cases, David moves to a particular city at which he dwells for a specified amount of time. ${ }^{37}$ Yet there are also significant differences between the two stories, the most striking of which is the absence of any communication with God in 1 Sam 27. As 27:1 shows, David's move is not based on divine instructions but simply on his own logic and his fear. While David is received favorably by the king of Gath and even receives a city where he and his men and their families can dwell, it quickly becomes apparent how problematic this move was. By seeking refuge with Achish, David loses his personal freedom and gets caught in a conflict of interests. Not only is he forced to lie to Achish (27:10), but he also comes dangerously close to having to fight against his own people (28:1-2). Furthermore, Ziklag does not turn out to be a place of safety, for in 1 Sam 30 the Amalekites burn the city and carry away the families of David and his men. All of this suggests that David's decision to leave the land was not in his or his followers' best interest and that it would have been better for him to inquire of the Lord. When he does so in 2 Sam 2, the result is much more positive: Instead of the one year and four months he spends at Ziklag, David dwells in safety at Hebron for at least seven and a half years. Thus, the allusions to 1 Sam 27 in 2 Sam 2 underscore the importance of divine guidance for the well-being of David and his followers.

\footnotetext{
${ }^{37}$ Significantly, the phrase occurs only in 1 Sam 27:7 and 2 Sam 2:11 in the entire Old Testament.
} 
Verse $4 \mathrm{a}$

Following his move to Hebron, David is anointed there by the men of Judah. There is no indication in the text that David initiated this anointing or undertook any other steps to become king. Even now he will not take the kingdom by force, but waits for the people to take the initiative. The anointing that takes place does not negate the earlier anointing in 1 Sam 16 to which it alludes. ${ }^{38}$ Rather "the men of Judah give visible public reality to the anointing long ago authorized by Yahweh," 39 thereby showing that they recognize David as the Anointed of the Lord and as their king. Thus "David is legitimized by both God and people."40

Special emphasis is placed on the fact that David is anointed "there" (שָ Hebron. As already mentioned above, Hebron is closely associated with the patriarchs and their return to the land from exile in the book of Genesis. The city is first mentioned in Gen 13 where Abram, like David, returns to the land by going up (עָד לדה) with his wife and all that belonged to him. He then separates from his "brother" Lot, who moves to Sodom (vv. 11-12), while Abram settles (ביָָ Hebron and there (نָT) builds an altar to YHWH (v. 18). As scholars have recognized, Gen 13 contains a number of allusions to the first few chapters of Genesis, in particular to the stories of creation and the fall. ${ }^{41}$ The most obvious of these is found in v. 10 where

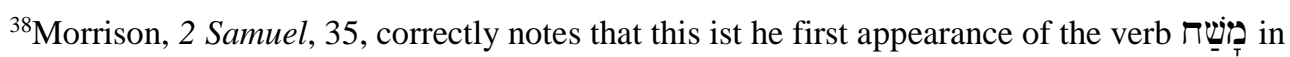
reference to a person since 1 Sam 16.

${ }^{39}$ Brueggemann, First and Second Samuel, 220. Cf. Steinmann, 25.

${ }^{40}$ Birch, "First and Second Books of Samuel," 1211.
} 
Lot sees that the whole plain of the Jordan, where Sodom is located, is watered like the garden of YHWH. Thus, the area where Lot chooses to settle is reminiscent of the garden in which Adam and Eve originally dwelled. Yet appearances are deceiving, for as v. 13 already suggests, this area only looks like paradise. ${ }^{42}$ In reality, it is a false garden, as the reference to the land of Egypt in v. 10 hints at. While the garden in Gen 2-3 is mankind's true home where peace and freedom reign, Egypt is associated with exile, bondage and death already in Gen $12 .^{43}$

In contrast to the false garden where Lot lives, the author presents the dwelling place of Abraham at Hebron. While Sodom is associated with evil and sin against God, Hebron is a place of worship to YHWH, for Abram built an altar to YHWH there (Gen

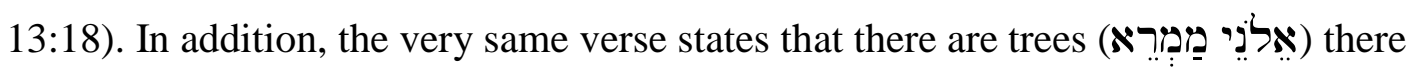
which again reminds of the garden in Gen $2-3$. This raises the possibility that the author wants to present Hebron as a kind of new paradise, i.e. the true garden that contrasts with the false garden Sodom. Such a view is further supported by the fact that the garden in Gen $2-3$ is presented as the first sanctuary and thus is the original place of worship. ${ }^{44}$ In

\footnotetext{
${ }^{41}$ See e.g. Kenneth Mathews, Genesis 1-11:26, NAC 1A (Nashville, TN.: B\&H Publishing, 1996), 136.

${ }^{42}$ Jacques Doukhan, Genesis, SDAIBC (Nampa, ID: Pacific Press Publishing Association, 2016), 209.

${ }^{43}$ Doukhan, Genesis, 209. That Lot's dwelling place is a false garden is also suggested by the fact that he moves east to get there (13:11). As the previous chapters in Genesis show, moving to the east is always connected to movement away from the garden and the presence of God. Instead of returning to the garden, Lot is thus actually moving further away from it.

${ }^{44}$ For the striking parallels between the description of the garden in Gen $2-3$ and the Mosaic and Solomonic sanctuaries see e.g. Richard M. Davidson, "Cosmic Metanarrative for the Coming Millennium," Journal of the Adventist Theological Society 11 (2000): 108-11; Richard M. Davidson, "Earth's First Sanctuary: Genesis 1-3 and Parallel Creation Accounts." Andrews University Seminary Studies 53 (2015): 65-89; Gordon J. Wenham, "Sanctuary Symbolism in the Garden of Eden Story," in "I Studied
} 
light of these connections it is not surprising that Hebron is later given to the priests, the sons of Aaron who work at the sanctuary, as a dwelling place (Josh 20:7; 21:11-13).

Thus, the city chosen by YHWH where David begins his reign may be associated both with the garden in Gen $2-3$ as well as with the sanctuary. If this is true, it would have significant implications for David's kingship, for his move to Hebron would then be a return to the garden, so to speak, raising the possibility that his kingship should be understood in terms of the original kingship given to the first humans. At the same time, the connection to the sanctuary would raise the possibility that David's kingship also includes a cultic dimension and that as anointed king David also has the role of a priest. This is confirmed in 2 Sam 6:17 where David offers burnt offerings and peace offerings as well as in 2 Sam 8:18 which states that the sons of David were priests.

\section{Verses 4b-7}

Verse $4 b$

From the anointing of David, the narrative now shifts to a report which David receives concerning the burial of Saul by the men of Jabesh-Gilead and his response to them. The term נגָר in v. 4b provides a verbal link to David's encounter with the young Amalekite in the previous chapter where the same term occurs five times (2 Sam 1:4, 5, $6,13,20)$, alerting the attentive reader that this is already the second report which David

Inscriptions from before the Flood": Ancient Near Eastern, Literary, and Linguistic Approaches to Genesis 1-11, eds. Richard S. Hess and David T. Tsumura (Winona Lake, IN: Eisenbrauns, 1994), 399-404; Michael Fishbane, Text and Texture: Close Readings of Selected Biblical Texts (New York: Schocken, 1979), 12-13; William J. Dumbrell, The End of the Beginning: Revelation 21-22 and the Old Testament (Grand Rapids, MI: Baker Books, 1985), 40-42; Jon D. Levenson, Sinai and Zion: An Entry Into the Jewish Bible (Oak Grove, MN: Winston Press, 1985), 142-45. 
receives concerning Saul after the latter's death. ${ }^{45}$ In both cases David must decide how the report is to be evaluated and is thus placed in the role of a judge.

In spite of these similarities, there are a number of significant differences between the two stories, in particular between the Amalekite man (שיש, 1:2) and the men of

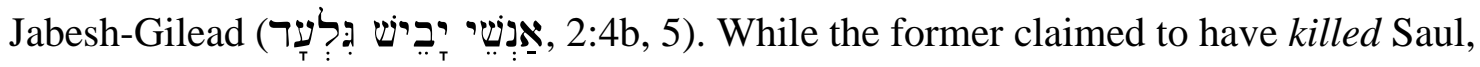
the latter buried Saul. Whereas it remains uncertain whether the report of the Amalekite is true or not, the narrative in 1 Sam 31 clearly testifies to the truthfulness of the report about the men of Jabesh-Gilead. While the Amalekite acted selfishly and for personal gain, the men of Jabesh-Gilead acted unselfishly and risked their own lives to show kindness to another. In the end, the Amalekite is punished and cursed, while the men of Jabesh-Gilead are rewarded and blessed. Both parties therefore receive from David what they deserve. From the start David's kingship is thus associated with the concept of just judgment that is based on the ability to discern between good and evil. ${ }^{46}$

That David pronounces this just judgment in both cases is all the more remarkable given that Saul was his enemy. In light of this, it would have been understandable if David had rewarded the Amalekite and punished the men of Jabesh-Gilead. However, as the interaction between Saul and David in 1 Samuel clearly showed, David is not interested in revenge for the sake of personal gain and vindication. He refuses to repay

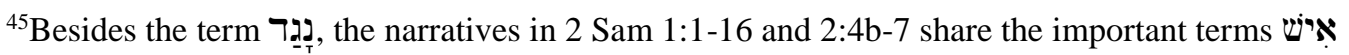

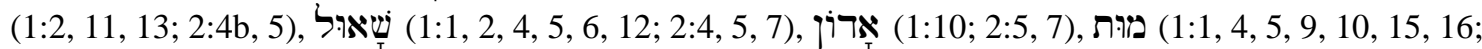

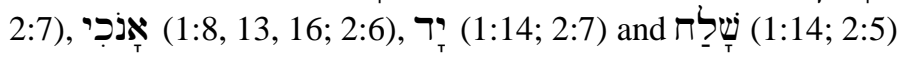

${ }^{46}$ The importance of this aspect of David's kingship is underscored by the fact that his just judgment with regard to the men of Jabesh-Gilead is presented as his first royal act after his anointing.
} 
evil with evil, but instead trusts YHWH to bring justice and to vindicate him. This attitude allows him to see the acts of the Amalekite and the men of Jabesh-Gilead in their true light and to administer true justice that is not swayed by personal opinions or sensitivities.

In combination with Jabesh-Gilead, the term נָָּ in v. $4 \mathrm{~b}$ also provides an interesting link between David and Saul, for like Saul in 1 Sam 11, David interacts with the men of Jabesh-Gilead after receiving a report concerning them. ${ }^{47}$ The fact that in both cases this interaction is presented as the first royal act of the newly anointed king once more suggests that David is the legitimate successor of Saul, appointed by YHWH to act

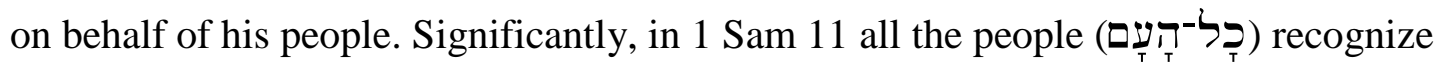
Saul as king after his interaction with Jabesh-Gilead (1 Sam 11:15), causing the reader to expect a similar reaction in 2 Sam 2. In response to David's interaction with JabeshGilead, however, a counter king is set up by Abner, causing the men of Judah and the men of Israel to fight against each other rather than joining together to defeat their enemies as in $1 \mathrm{Sam} 11$. Thus, the allusion to $1 \mathrm{Sam} 11$ also highlights the failure of the entire nation to recognize David as the legitimate heir of Saul's throne and the disastrous consequences this has for the well-being of the people.

Verse 5

In response to the report he receives concerning the men of Jabesh-Gilead, David sends a message of appreciation and encouragement to them. This act of David is

${ }^{47}$ Vannoy, 1-2 Samuel, 273; Leithart, A Son to Me, 182. 
significant not just because the men of Jabesh-Gilead were potential personal enemies, but also because Jabesh-Gilead lay east of the Jordan in the territory inhabited by the tribes of Reuben, Gad and half of Manasseh. The desire of these tribes to dwell outside of the Promised Land (see Num 32) had not only separated them physically from the rest of Israel but had also caused tensions between them and the other tribes (see e.g. Josh 22). In light of this background, it is noteworthy that David's first recorded act as king is to reach out to a city located in this territory with a message of חֶֶ, for it seems to be a first indicator that from the very beginning of his kingship David is interested in the unity of Israel that is based on the concept of showing to to one another.

David begins his message by expressing his desire that the men of Jabesh-Gilead

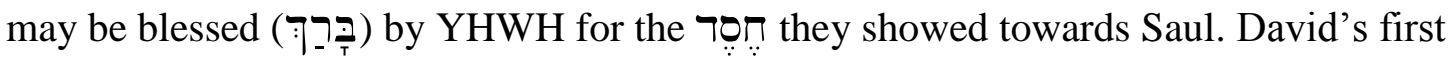
royal utterance is thus a word of blessing that communicates his interest in the well-being of these potential enemies and indicates his approval of what they did. That David would feel this way is not really surprising given the way he himself treated Saul. ${ }^{48}$ As a result David was blessed - first by Abigail (1 Sam 25:27) and then by Saul himself (1 Sam 26:25). Thus, David's message is directed to people who have the same attitude he does and expresses his desire for them to be blessed just as he himself was blessed. The good he has received they should receive as well. It should be noted, however, that he does not pronounce a blessing upon them himself, but wishes them to be blessed by YHWH.

\footnotetext{
${ }^{48}$ Bergen, 1,2 Samuel, 298: "David was impressed by this courageous act, for it mirrored his own respect for the royal family."
} 
Hence, David does not present himself as the one from whom all blessings flow but humbly focuses attention on YHWH as the true and ultimate source of blessing.

The wording of David's opening statement is also noteworthy, since the exact

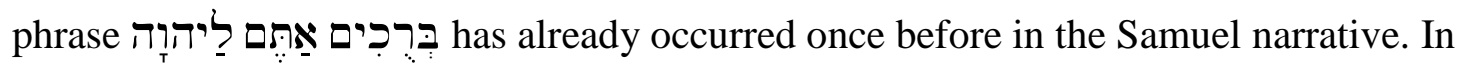
1 Sam 23:21 these words are spoken by Saul to the Ziphites who have just revealed to him that David is hiding in their territory. By repeating this phrase in 2 Sam 2:5, the author once again emphasizes that David is not like Saul. Saul wishes a divine blessing upon the Ziphites for betraying the Anointed of YHWH who had not done him any harm. David, on the other hand, wishes a divine blessing upon the men of Jabesh-Gilead for showing

It is significant that David does not simply commend the men of Jabesh-Gilead for burying Saul but explicitly designates their action as "is difficult to translate adequately," 49 is one of the keywords in David's message, occurring not just in v. 5 but also in v. 6 . A survey of the over 250 occurrences of the term in the Old Testament reveals that it is "associated with covenants and commitments" 50 and "often presupposes an existing relationship... within which it operates." party, who for one reason or another is unable to help himself or herself." 52 Thus the term

\footnotetext{
${ }^{49}$ Anderson, 2 Samuel, 29.

${ }^{50}$ Vannoy, 1-2 Samuel, 1212.

${ }^{51}$ Anderson, 2 Samuel, 29.

${ }^{52}$ Arnold, 1 \& 2 Samuel, 421.
} 
is variously translated with words such as "kindness," "mercy," or "love." 53 In the present context it is probably best rendered as "loyalty" or "faithfulness," since David twice refers to Saul as the lord of the men of Jabesh-Gilead (vv. 5 and 7), though this does not necessarily exclude the other connotations just mentioned.

David's first recorded act as king is thus to commend people who were loyal and faithful subjects of their lord and king and proved their loyalty by risking their lives in order to help him when he was unable to help himself, in spite of the fact that they could not hope for any reciprocation on his part. Hence, from the very beginning of his kingship David explicitly affirms this kind of loyalty which significantly stands in stark contrast to the attitude of Israel toward its designated lord and king David at this point in the narrative, given that only Judah has recognized David as its king and the other tribes become part of Abner and Ish-boshet's counter kingdom. It also stands in contrast to the disloyalty of Joab, Abner and the sons of Rimmon to their respective lords David and Ishboshet in the following narratives. These contrasts as well as the fact that the example of the men of Jabesh-Gilead is mentioned by David in his role as king at the very beginning of 2 Sam $2-4$ once again suggest that the attitude of the men of Jabesh-Gilead is presented as a praiseworthy ideal and key foundation of David's kingship.

That the men of Jabesh-Gilead showed חִ also once more connects them with David, since the last time the term occurred previously in Samuel was in 1 Sam 20 where

${ }^{53}$ R. Laird Harris, “חֶי.," TWOT 1:305. 
David and Jonathan agree to show דִֶ? to one another and to their houses. ${ }^{54}$ The attentive reader is thus reminded that David himself is a man of those who have the same attitude. At the same time the term links the men of JabeshGilead with YHWH who is most strongly associated with the term in the Old Testament and explicitly presents himself as a God of חִ in Exod 34:6-7. Thus, David is here commending people who not only act like himself, but also and more significantly act like YHWH. This is interesting in light of the possible association of Hebron with the garden in Gen 2-3 mentioned above, for it raises the possiblity that David's kingship is connected to the restoration of man into the image of God. Under David's leadership people are to emulate God's character and to treat each other as God treats them.

Verse 6

As scholars have recognized חְִֶ "usually has an element of reciprocity: one good deed should give rise to a corresponding action." 55 In light of this it is not surprising that in v. 6 David expresses his wish for the men of Jabesh-Gilead to be shown return for what they did. Since Saul is dead and therefore cannot reciprocate, another must take his place. Here now comes the surprise, for David does not mention Saul's descendants as would normally be expected, thus subtly indicating that the house of Saul

\footnotetext{
${ }^{54}$ The connection between David and the men of Jabesh-Gilead is also made evident by the fact that David previously referred to Saul as "his lord" (אָרון, see e.g. 1 Sam 24:9, 11; 26:17-19). Though the term is not mentioned in connection with David's interaction with Saul, both David and the men of Jabesh-Gilead showed kindness to their lord Saul.

${ }^{55}$ Anderson, 2 Samuel, 29.
} 
had no more claim on the kingdom. Yet significantly David also does not initially present himself as the one who will show חֶֶ, but YHWH. As in the opening line of his message David thus once again focuses on YHWH, who is the ultimate giver of seeking to draw attention to himself. What is most important to him is that the men of Jabesh-Gilead experience the blessing and kindness of YHWH.

But it is not only חֶֶֶ which YHWH is to show but also That both terms are mentioned together here does not appear to be accidental, for the only time the phrase

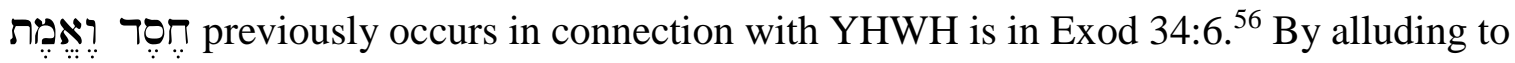
YHWH's self-presentation in the context of his renewal of the covenant with Israel at Sinai, David seems to remind the men of Jabesh-Gilead of their covenant relationship with YHWH which is still valid even after their covenant relationship with Saul has come to an end ${ }^{57}$ David's primary desire as newly crowned king therefore seems to be to draw attention to YHWH as both the true source of blessing and the true Lord of Israel.

Only now does David introduce himself into the picture, but he does so emphatically: "I also, I will do this good to you because you have done this thing." Already through the opening بִ David establishes a connection to what was said before.

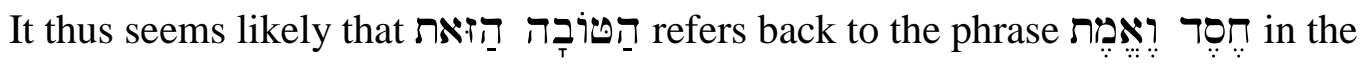
previous statement. This is significant for at least three reasons. First, it means that

${ }^{56}$ vom Orde, Das zweite Buch Samuel, 41; Bergen, 1,2 Samuel, 298.

${ }^{57}$ Brueggemann, First and Second Samuel, 220f.: „It is as though David reminds the city that it can expect no more hesed from Saul, who is dead and has no more hesed to give, but may find adequate hesed in the enduring inclination of Yahweh." 


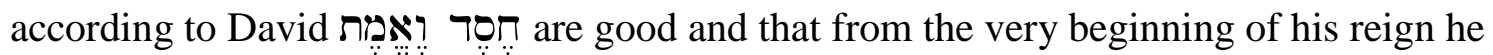
closely identifies himself with these good qualities. Second, it means that David is saying

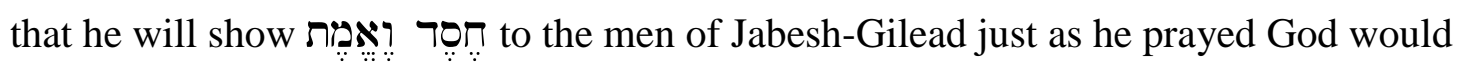
do. David thus also closely identifies himself with God. ${ }^{58}$ As God does so David does. ${ }^{59}$

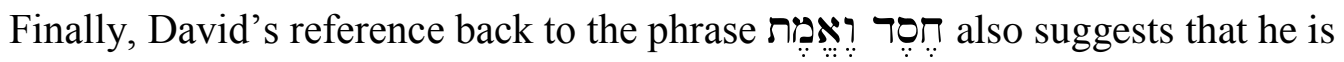
presenting himself as covenant partner to them who will treat them in the same way that he prays their divine covenant partner will. ${ }^{60}$

Yet despite the probable connection between should also be noted that two different phrases are used. The fact that David does not

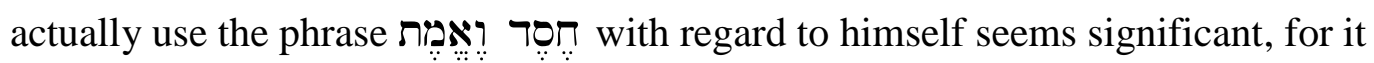
suggests that in spite of the close connection between David and God, David recognizes that there is a difference between them. David will act like God, but through his choice of words he indicates that he is not identical to God. This once again shows that David is well aware of who he is and what his place is in relation to God.

${ }^{58}$ Fokkelman, Throne and City, 32: “The speaker has placed his activity on the same level as God's and in so doing has taken his place right next to God."

${ }^{59}$ This further strengthens the connection between David and the first humans in the garden, since they were created in the image of God (Gen 1:26) to live and act like God.

${ }^{60}$ Significantly, a number of studies have recently come to the conclusion that the term certain contexts may refer to covenantal relationships." (Anderson, 2 Samuel, 29) See e.g. Michael Fox, "Ṭ̂o b as Covenant Terminology," Bulletin of the American Schools of Oriental Research 209 (1973): 4142; Ingeborg Johag, "ט - Terminus Technicus in Vertrags- und Bündnisformularen des Alten Orients und des Alten Testaments," in Bausteine Biblischer Theologie, ed. Heinz-Josef Fabry (BBB 50. Köln und Bonn: Peter Hanstein Verlag, 1977), 3-23. 
The reason David gives for doing good to the men of Jabesh-Gilead is "because you have done this thing." Once again, the word choice here is interesting, since this is not the first time the phrase הָדָדָר הַזְז has occurred in Samuel. In 1 Sam 18:8 it refers to the singing and dancing of the women after the victory against the Philistines, which is evil in the eyes of Saul and causes him to become jealous of David (1 Sam 18:9). This jealousy eventually leads him to seek David's life - which Jonathan refers to as הַ:ְִ

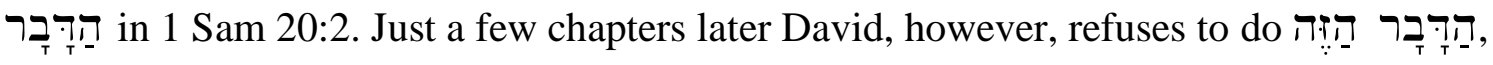
namely kill Saul (1 Sam 24:7). The phrase thus reminds of the conflict between Saul and David and the loyalty and kindness David showed Saul which was similar to the loyalty and kindness that the men of Jabesh-Gilead showed Saul. Because David refused to do

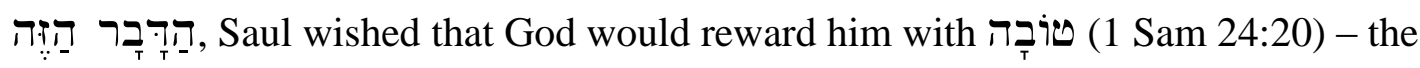
exact same thing David promises to do to the men of Jabesh-Gilead because of הָז

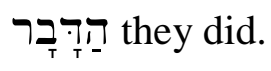

These parallels between David and the men of Jabesh-Gilead become significant in light of the fact that Abner, who is about to make his appearance in $2 \mathrm{Sam} 2: 8$, is also

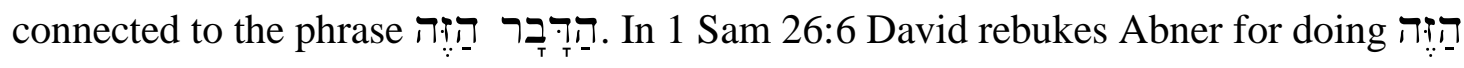

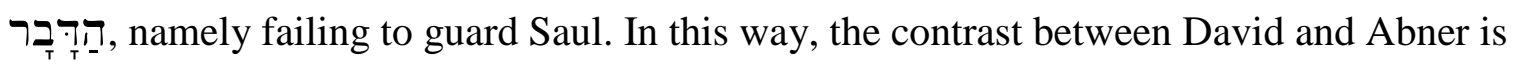
made evident. While Abner, the commander of Saul's army (1 Sam 14:50), failed to protect his lord, David, who basically took Abner's place (1 Sam 18:5, 13), protected Saul by twice refusing to kill him and preventing his men from doing so. This unselfish loyalty to Saul connects David to the men of Jabesh-Gilead. While Abner also shows loyalty to Saul by making his son king in 2 Sam 2, the following narratives show that it is 
a loyalty that is based on selfish motives and which provokes conflict. It is also a loyalty

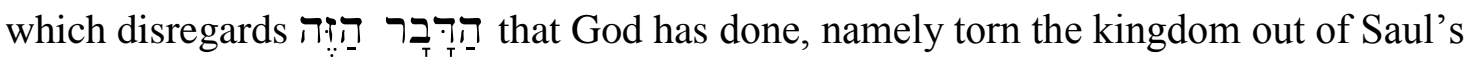

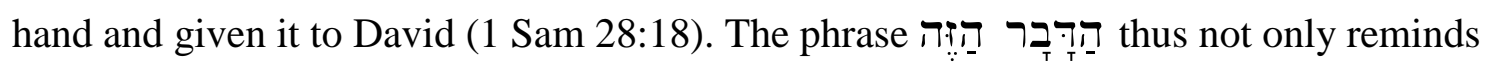
of the legitimacy of David's kingship, but also strengthens the connection between David and the men of Jabesh-Gilead. David, and not Abner or Ish-boshet, is therefore both the legitimate as well as the most suitable leader for the Jabesh-Gileadites.

Verse 7

Having declared what he and YHWH will do, David in closing now shifts the focus back to the men of Jabesh-Gilead. He first encourages them to respond to the blessings they are to receive by letting their hands be strengthened and being sons of valor. That this statement follows immediately on the heels of v. 6 is noteworthy, for it suggests that strength and valor are here not based on typical human categories such as military ability or size (e.g. quantity of soldiers, quality of weapons, etc.) but instead are presented as the result of an intact covenant relationship with YHWH and his Anointed. In this way the importance of being connected to YHWH and guided by him for the success of David's kingship is once again emphasized.

David ends his message to the men of Jabesh-Gilead by reminding them that their lord Saul is dead and informing them that the house of Judah has anointed him king over them. This is as close as David gets to openly inviting the Jabesh-Gileadites to transfer loyalty to him and accept him as king. While Morrison interprets David's words as “a 
veiled threat, ${ }^{, 61}$ it is difficult to find any support in the text for such a negative reading. Rather, it is worth noting, as Fokkelman does, that David once again does not focus primarily on himself (as in: "I have become king") but on the fact that the people of Judah have anointed him as king. ${ }^{62}$ In this way he sets before the men of Jabesh-Gilead the example of a significant entity within Israel which has recognized and affirmed his call to the throne by YHWH himself and gives them the opportunity to do likewise. The fact that the message contains no threat in case they decide not to accept him as king suggests that they are free to choose without fear of reprisal from David. This says much about David's kingship: it is not based on fear or manipulation but on kindness and free choice.

\section{Verses 8-11}

Verse 8

No response from Jabesh-Gilead, whether negative or positive, is reported. Instead, the narrative abruptly shifts to a new character, who is no stranger to the reader of Samuel: Abner, the son of Ner, the commander of Saul's army. ${ }^{63}$ His appearance at this point of the narrative is significant for a number of reasons. First, it reveals that he survived the battle against the Philistines on Mount Gilboa, which in turn raises the question why he survived and what role he played in the events in 1 Sam 31. It is striking that as commander of Saul's army Abner is never mentioned in the report of the battle.

\footnotetext{
${ }^{61}$ Morrison, 2 Samuel, 36.

${ }^{62}$ Fokkelman, Throne and City, $31 \mathrm{f}$.

${ }^{63}$ The break is signaled not only by the introduction of a new character but also by the fact that v. 8 begins with a noun instead of a verb (Morrison, 2 Sатиel, 37).
} 
Did he flee like the rest of the men of Israel (1 Sam 31:1)? Or did he try to defend his lord Saul against the attacks of the Philistines? Even if this was the case, he apparently did not do so to the point of death.

The appearance of Abner right after David's message to the men of Jabesh-Gilead further raises the question why Abner did not rescue Saul's body from the wall of Bethshan. His failure to do so is all the more striking given that Abner was not just Saul's highest military official but also his cousin (1 Sam 14:50-51), as the author reminds us through the added "the son of Ner" in 2 Sam 2:8, and thus had a much closer relationship to the fallen king than the men of Jabesh-Gilead. Yet Abner's apparent absence from the events surrounding Saul's death is not surprising, since he had previously shown himself to be incapable of protecting Saul. As was pointed out above, he did הַדָר הַזרזה , which David pronounced not good: he did not watch over his lord Saul. Because of this, he and

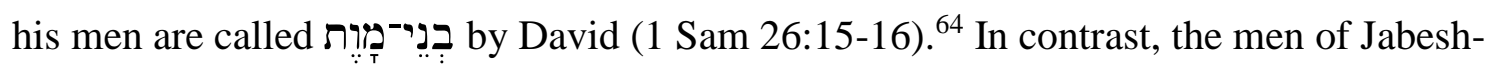

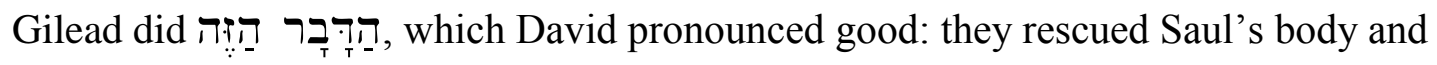
buried it. Because of this David encourages them to be בְני־חיזיל . Thus, before Abner has said or done anything in 2 Sam 2 , he is already placed in a negative light simply through his appearance at this point of the narrative and the resulting comparison with the men of Jabesh-Gilead.

Since Saul was also Abner's lord, David's words to the men of Jabesh-Gilead at the end of v. 7 are relevant for Abner as well. Like the men of Jabesh-Gilead, Abner must

\footnotetext{
${ }^{64}$ Though Abner appears four times previously to 2 Sam 2, he is only called "the son of Ner" in 1 Sam 14 and 26, suggesting that these two appearances are of particular significance for 2 Sam 2. 
acknowledge that his lord is dead and decide who his new lord will be. As his actions in vv. 8-9 show, he is clearly not interested in accepting David as his lord. Instead, he makes Saul's son Ish-boshet king. Though this might initially seem to be an act of loyalty to Saul and thus mirror the loyalty of the men of Jabesh-Gilead, Abner's track record discussed above raises doubts as to whether this is indeed the case. This raises the possibility that Abner's move in vv. 8-9 is motivated primarily by other motives than loyalty to Saul. It is noteworthy, for example, that though Ish-boshet becomes king, Abner is the active agent both in Ish-boshet's installment and during his short reign. ${ }^{65}$ Thus, it seems that the real power lies with Abner, suggesting that Abner installed Ishboshet as king primarily for selfish reasons. ${ }^{66}$

The placement of Abner's actions right after David's statement in v. 7 that he has been anointed king over the house of Judah as well as the syntax of v. 8 also suggest that Abner's move should be interpreted as an act of defiance against David as well. ${ }^{67}$ This would not be surprising given the past interaction between the two men. As noted above, though Abner was the official commander of the army, the real military leader of Israel was David. Abner would have been aware of this and may very well have been jealous of David. Even if this was not the case, he nevertheless joined Saul in his hunt for David. Furthermore, David publicly rebuked Abner for not properly protecting Saul and

\footnotetext{
${ }^{65}$ That the focus is on Abner is already indicated by the placement of his name in the initial position in v. 8 .

${ }^{66} \mathrm{McC}$ arter, II Samuel, 85; Arnold, 1 \& 2 Samuel, 433f. See also Hans W. Hertzberg, I \& II Samuel, OTL (Louisville, KY: Westminster John Knox Press, 1964), 249 and Gnana Robinson, Let Us Be Like the Nations: A Commentary on 1 \& 2 Samuel, ITC (Grand Rapids, MI: Eerdmans, 1993), 160.

${ }^{67}$ As pointed out above, Abner's name is in the initial position in v. 8, meaning that the preceding waw must be understood in a disjunctive sense: „But Abner...”
} 
indirectly presented himself as the true and faithful guardian of Saul's life in 1 Sam 26. All of this makes it quite likely that Abner was not particularly fond of David and that he made Ish-boshet king at least in part to hurt David. If this was indeed the case, Abner's attitude and motives in setting up his counter kingdom would stand in stark contrast to those of David, thus highlighting even more David's unselfishness and kindness towards his enemies which characterized his rise to the throne.

The contrast between Abner and David is further made evident through Abner's first action in v. 8. While David's first action in v. 1 is to humbly inquire of the Lord what he should do, Abner takes Saul's son Ish-boshet, apparently without seeking divine guidance. ${ }^{68}$ The verb לְָ underscores that the real power in this counter kingdom lies with Abner. ${ }^{69}$ Ish-boshet is like an object with no will of its own that may be taken and used as Abner pleases. From the very beginning, Ish-boshet is thus presented as a weak character who in contrast to David is unable to take action himself but is continually acted upon by another.

The negative impression of Ish-boshet is further underscored by his name which means "man of shame." This was probably not his real name. Most scholars believe that "Ish-boshet" is an intentional alteration of either "Ishbaal" or "Eshbaal" (1 Chr 8:33; 9:39) done by later scribes or editors who wanted to avoid or even defame the name of

${ }^{68}$ Birch, "First and Second Books of Samuel," 1212; Arnold, 1 \& 2 Samuel, 434.

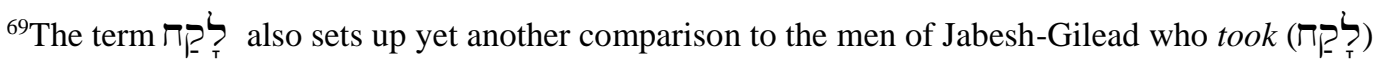
the bodies of Saul and his sons and buried them (1 Sam 31:12-13). While both actions could initially be interpreted as חִָ toward Saul, a closer look at the text suggests that in contrast to the Jabesh-Gileadites who unselfishly took those who were unable to help themselves, Abner's taking is motivated by the selfish desire to help himself. In this he is like the young Amalekite in 2 Sam 1 who took (לְקָ) Saul's crown and bracelet in order to win David's favor. 
the pagan god Baal. ${ }^{70}$ Though it cannot be completely ruled out that the name was changed at a later time, it is by no means a necessary conclusion, since the name Ishboshet fits quite well into the immediate and wider context of 2 Sam 2 and could thus very well have been part of the original text. It should be noted, for example, that this is not the first occurrence of the term איש in this literary unit. In 2 Sam 2:3 the men of David are mentioned who move up to Hebron with him. These are his most loyal supporters who stood by him when it was far from certain that he would actually be king one day. They are joined in v. 4 by the men of Judah who come to Hebron and anoint David, thus recognizing him as their king. This is followed in the narrative by David's message to the men of Jabesh-Gilead, in which he indirectly invites them to follow the example of the men of Judah and accept him as their lord and king. No reaction is reported leaving the reader uncertain whether they recognized David as king or not. The final man in this series is Ish-boshet, the man of shame, who like Abner clearly does not recognize David's kingship, but instead tries to continue Saul's kingship, thus disregarding the fact that God tore the kingdom from Saul and gave it to David. This suggests that as at the very beginning of the biblical story, shame is connected to disobedience to God which in this particular case expresses itself in the rejection of David's kingship and the attempt to set up a kingship in opposition to God's command.

\footnotetext{
${ }^{70}$ See e.g. Arnold, $1 \& 2$ Samuel, 433; Anderson, 2 Samuel, 32; Birch, "First and Second Books of Samuel," 1212f.; Hertzberg, I \& II Samuel, 249. This view is challenged by Tsevat who on the basis of

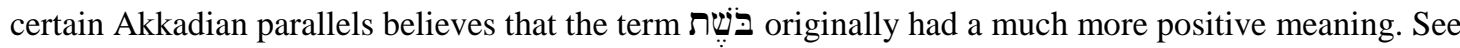
Matitiahu Tsevat, "Ish-boshet and Congeners: The Names and Their Study," Hebrew Union College

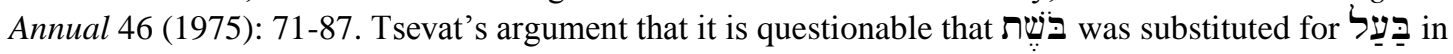
biblical times is in turn disputed by McCarter who cites two biblical examples where such substitutions were clearly made. See McCarter, II Samuel, 85-86.
} 
Interestingly, shame is also connected to the issue of loyalty to David in 1 Sam 20, the only place where the term בּּשֶׁת previously occurs in Samuel. In this chapter Saul becomes angry with Jonathan because of his loyalty to David and says to him: "You son of a perverse, rebellious woman! Do I not know that you are choosing the son of Jesse to your own shame and to the shame of your mother's nakedness?" (1 Sam 20:30) In a way Jonathan, who was the heir to the throne, is here considered to be a man of shame for choosing David, which included the recognition that David was chosen by God to be the next king. Yet 2 Samuel 2 seems to suggest that the real man of shame was the son of Saul who failed to recognize David as king and instead allowed Abner to make him king. ${ }^{71}$ Thus the counter kingship which Abner and Ish-boshet set up is from the very beginning associated with shame.

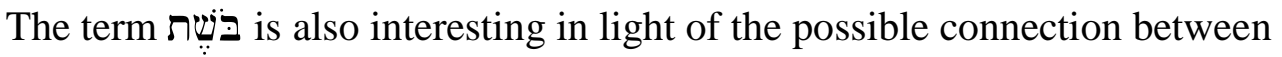
David and the first humans noted above. While David seems to be connected with the obedient Adam who is guided by YHWH and receives the kingship at Hebron without any effort of his own, the term disobedient Adam (the first man of shame) who rebels against the divine plan and seeks to rule on his own terms, leading to his departure from the garden. In light of this it is interesting that Ish-boshet's reign begins with him being brought to Mahanaim, a location outside of the Promised Land that is so similar to Eden and the garden. ${ }^{72}$ The verb that is

\footnotetext{
${ }^{71}$ That a comparison between Jonathan and Ish-boshet is indeed intended at this point is further suggested by the fact that Ish-boshet is repeatedly identified as was previously used only to describe Jonathan (1 Sam 14:1; 19:1; 23:16).
} 
used here is עִבָר which means "to pass over" or "to cross over" and occurs numerous times in the context of Israel crossing over into Canaan. ${ }^{73}$ Ish-boshet also crosses over, but in the wrong direction. While David is moving into the land at the beginning of 2 Sam 2, Ish-boshet is going the other way. This once again highlights the contrast between the two kingships and casts a negative light on Ish-boshet's kingship.

It also may not be accidental that the only other time the exact same form of the verb עָברָ occurs in the Old Testament is in the context of the anointing of David in 1 Sam 16:8 where Jesse causes Abinadab to pass before Samuel, who is not chosen by YHWH. In the following two verses the hiphil of עָרבר occurs two more times as the sons of Jesse are made to pass before Samuel, none of whom are chosen by YHWH. All individuals connected with the verb עָָָר in 1 Sam 16 are thus not chosen by YHWH. The reappearance of the hiphil of עָָרבר in 2 Sam 2:8 just after the anointing of David by the men of Judah that also reminds of 1 Sam 16 may therefore be both a subtle hint that Ishboshet also is not chosen by YHWH as well as a reminder that David is the chosen one of YHWH.

As in David's case, Ish-boshet's kingship is associated with a city, namely Mahanaim. No reason is provided for this choice, leading many commentators to

\footnotetext{
${ }^{72}$ The close connection between Eden and the Promised Land already seems to be made evident in the book of Genesis. As a number of scholars have recognized, for example, both the Euphrates and Tigris rivers mentioned in Gen 2:14 are said to be boundary markers of the land which God promised to Abram in Gen 15:18. Thus the author of Genesis appears to present the Promised Land as a new Eden. See e.g. Matthews, Genesis 1-11:26, 208; John H. Sailhamer, The Pentateuch as Narrative (Grand Rapids, MI: Zondervan, 1992), 99; Paul J. Kissling, Genesis Volume 1, CPNIVC (Joplin, MO: College Press Publication Co., 2009), 162.

${ }^{73}$ E.g. Deut 6:1; 9:1; 27:2, 3, 4, 12; 30:18; 31:2, 3, 13; 32:47; 34:4; Josh 1:2, 11, 14, 15; 3:1, 2; etc.
} 
speculate that Abner brought Ish-boshet there because the city was located east of the Jordan and therefore outside the reach of the Philistines. ${ }^{74}$ While this is possible, it remains speculative. Nevertheless, the move to Mahanaim does not appear to be insignificant. First, the name of the city means "two camps" and this is precisely what Abner was creating by making Ish-boshet king there. In contrast to David, who reigns from a city whose name is associated with unity, Ish-bosheth thus begins his reign in a city whose name is associated with division. ${ }^{75}$ Furthermore, according to Joshua 13:26 and 13:30 Mahanaim seems to have been located on the border of the tribe of Gad and the half-tribe of Manasseh. While Abner may have moved Ish-boshet there for strategic reasons, the location once again reminds the attentive reader of the desire of these tribes to dwell outside of the land and the threat this presented to Israel's unity at the time of the conquest. In the end, Gad, Reuben and the half-tribe of Manasseh agreed to fight with the rest of Israel against the Canaanites and afterwards built an altar at the Jordan to be a witness between them and the rest of Israel that they would stay faithful to God (Josh 22:21-29). Thus, the unity of Israel was preserved. Abner's move of making Ish-boshet king presents a similar threat to Israel's unity, but neither he nor Ish-boshet have the attitude of the two and half tribes. Instead of joining David in his quest to finish the conquest, they cause division in Israel which leads to civil war.

\footnotetext{
${ }^{74}$ Anderson, 2 Samuel, 33; vom Orde, Das zweite Buch Samuel, 43; Bergen, 1,2 Samuel, 276; Birch, "First and Second Books of Samuel," 1213; McCarter, II Samuel, 87; Hertzberg, I \& II Samuel, 249.

75 Hebron appears to be related to the verb רבָר fellowship with." Hence, Hebron could be translated as "confederacy," "association," or "league.” See Gerard van Groningen, "רבָר Rasmussen, "Hebron," NIDOTTE 4:698.
} 
It should also be noted that the mention of Mahanaim provides another link to the Jacob story, where the name first occurs (Gen 32:3). This is interesting in light of the parallels between David and Jacob at the beginning of 2 Sam 2, as shown above. While both kings are thus connected to Jacob, a careful reading of the text shows that only David is truly like Jacob. Like the patriarch he returns to the land with his two wives in response to a divine command and is intent on bringing about peace and harmony between brothers. Ish-boshet, on the other hand, only superficially appears to be like Jacob. Though he moves to Mahanaim, he leaves the land without any mention of wives and sets up a counter kingdom in defiance of the divine command, causing division and strife between brothers as the immediately following narratives in 2 Sam $2-4$ show. While Jacob names the place Mahanaim to remind of the presence of God's camp with his own camp, Abner and Ish-boshet enjoy no such divine support. In their case Mahanaim thus does not indicate the presence of God's camp with their own camp, but rather foreshadows the division of Israel into two camps that results from their disregard of the divine will. Thus Ish-boshet appears to be a Pseudo-Jacob who functions as a foil for the true Jacob, David.

Finally, like Hebron, Mahanaim is one of the cities given to the Levites in Josh 21. Yet while Hebron is the very first city that is mentioned and is given to the sons of Aaron, Mahanaim is one of the last cities that is mentioned and is given to the sons of Merari. In contrast to Hebron, Mahanaim also is not a city of refuge. Hence Mahanaim does not seem to have the same status or significance that Hebron does. This may provide a further hint that David's kingship is superior to that of Ish-boshet. 
Verse 9

Having brought Ish-boshet to Mahanaim, Abner makes him king. As already noted above, this single-handed enthronement of Ish-boshet by Abner contrasts starkly with the anointing of David by the men of Judah. While David's enthronement is thus a "popular act," Ish-boshet's installation as king is "an inside job for which no popular support is reported."76 In light of this it is not surprising that the hiphil form of the verb

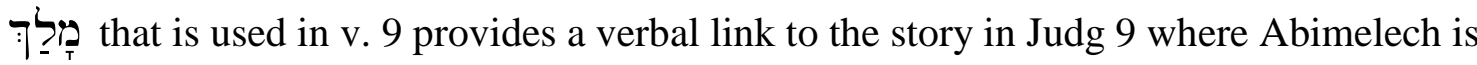

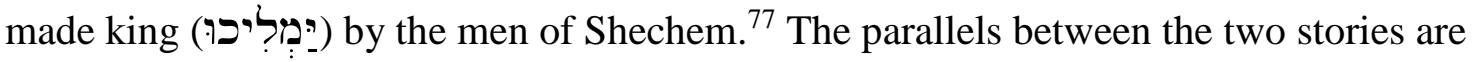
striking:

(1) Both Abimelech and Ish-boshet are illegitimate kings who ascend to the throne by questionable means (Judg 9:1-6; 2 Sam 2:8-9).

(2) Their enthronement is followed by civil war between Israelite brothers (אָ) that ends in death and the self-destruction of their kingdom (Judg 9:22-57; 2 Sam 2:8$4: 12)$.

(3) The dishonorable death of both kings is connected to the head (ראזי) (Judg 9:5354; 2 Sam 4:7-8).

These similarities to the story of Abimelech do not reflect positively on Ish-boshet and his kingship. Instead they suggest that like Abimelech, Abner and Ish-boshet did not

\footnotetext{
${ }^{76}$ Brueggemann, "First and Second Book of Samuel," 221. Campbell notes that this is the only time in the Old Testament that an army commander makes another man king. (Campbell, 2 Samuel, 34)

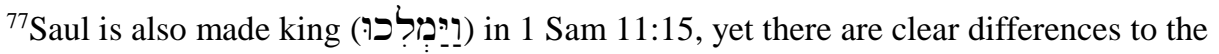
enthronement of Abimelech and Ish-boshet: (1) Saul was made king because he had been previously chosen by God, anointed by Samuel and had just brought salvation to Israel by defeating Nahash the Ammonite, (2) he was made king by "all the people," and (3) he was made king "before YHWH."
} 
act "in truth and sincerity" (Judg 9:16), but repaid good with evil. Because of this their kingdom will eventually destroy itself.

In 2 Sam 2:9, however, Abner and Ish-boshet's prospects are still looking good. Ish-boshet is not just made king but also has a sizeable kingdom, especially in comparison to David. While David is king only over Judah, Ish-boshet rules over Gilead, the Assurites, Jezreel, Ephraim, Benjamin and all Israel. As scholars have noted, Ishboshet's territory thus comprises the areas north of Jerusalem that later make up the northern kingdom. ${ }^{78}$ This once again does not cast Ish-boshet's kingdom into a favorable light, since the northern kingdom does not have a single king who does what is right in God's eyes and is presented as being in constant rebellion against YHWH.

Verse 10

After specifying Ish-boshet's territory, the author provides Ish-boshet's age when he became king as well as the length of his reign. Again, both of these details seem to be deliberately included in order to contrast Ish-boshet with David and to thus highlight the true nature of Ish-boshet's reign. Whereas Ish-boshet is forty years old when he becomes king and reigns only two years, David is ten years younger at the beginning of his reign and his kingship lasts for forty years (2 Sam 5:4). Intruigingly, the only previous reference to a two-year reign is found in 1 Sam 13:1 which states that Ish-boshet's father

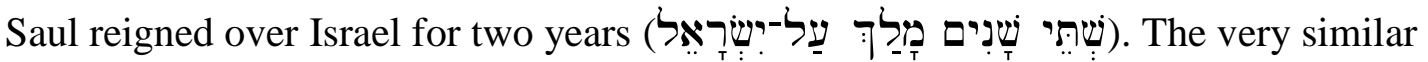
wording to 2 Sam 2:10 associates the rebellious Ish-boshet with the rebellious Saul and

${ }^{78}$ Morrison, 2 Samuel, 38; vom Orde, Das zweite Buch Samuel, 43. 
suggests that he will share the fate of his father. This is exactly what happens: Ishboshet's kingship does not last and like his father he dies an unnatural death and has his head cut off (1 Sam 31:4, 9; 2 Sam 4:7). Like Saul, Ish-boshet is unfit to be king over Israel because he (together with Abner) refuses to listen to and wait on YHWH (as David does), but takes matters into his own hands. As a result, Ish-boshet and Abner, like Saul, oppose their fellow Israelite David and his men instead of fighting against Israel's enemies and finishing the conquest.

The author now shifts the focus back to David, noting that the house of Judah was behind David. This not only reminds the reader that although Ish-boshet is king over all Israel, his kingship is not recognized by all Israel, but also provides another contrast between the two kings. While the house of Judah is behind David, indicating their loyalty and support, no such statement is made with regard to Ish-boshet. This is not surprising given that the people of Israel seem to have had no say in the decision to make Ish-boshet king. Ish-boshet may rule over Israel but it is an imposed kingship that may well lack popular support.

\section{Verse 11}

David's superiority over Ish-boshet is emphasized once more in the final verse of the literary unit. While Ish-boshet reigns for just two years, David is king at Hebron over the house of Judah for seven and a half years. It is interesting to note that the phrase occurs only one other time in the Old Testament, namely in 1 Sam 27:7. This does not seem accidental since, as already noted above, there are several other parallels between 1 Sam 27:1-7 and 2 Sam 2:1-11. Both passages mention David's two 
wives by name as well as his men and their houses (1 Sam 27:3; 2 Sam 2:2-3). Also, in both passages David and his men settle in a certain city (1 Sam 27:6; 2 Sam 2:3). Finally, both passages mention kings of Judah (1 Sam 27:6; 2 Sam 2:4, 7, 11). These parallels invite the reader to compare the two passages and note the differences between them. While David does not consult God in 1 Sam 27 but leaves the land out of fear to dwell in the Philistine city Ziklag for one year and four months, he inquires of the Lord and courageously moves back into the land to dwell at Hebron for seven years and six months in 2 Sam 2. 2 Sam 2:1-11 must therefore be understood as the reversal of 1 Sam 27:1-7. This once again places David's experience in the former passage in a positive light.

Implications for the Nature of David's Kingship

From the above exegetical analysis, a number of significant implications may be drawn regarding the nature of David's kingship.

\section{The Legitimacy of David's Kingship}

The legitimacy of David's kingship is affirmed throughout 2 Sam 2:1-11, in particular through (1) comparison and contrast to Ish-boshet's kingship and (2) allusions and parallels to previous passages in the Old Testament.

Chosen by $Y H W H$. The allusions to 1 Sam 16 in vv. 4 and 8 are a reminder that David was chosen by YHWH and anointed by YHWH's prophet to be king over Israel. As the object of the hiphil form of the verb עיעבר Ish-boshet, on the other hand, is associated with David's brothers whom YHWH had not chosen. 
Recognized by Saul. The allusions to 1 Sam 24 and 26 throughout vv. 1-11 are a reminder that David's predecessor Saul himself recognized that David would be king over Israel. No such statements are made by Saul with regard to Ish-bosheth.

Recognized by the people. David does not make himself king, but is anointed by the men of Judah who thereby appear to recognize and affirm the anointing of 1 Sam 16. In contrast, Ish-bosheth is never anointed, but made king over Israel by Abner without any recognition by the people.

Associated with the faithful Saul. Both David and Ish-bosheth are associated with Saul in the present literary unit. However, while Ish-bosheth is linked to the disobedient and rejected Saul of 1 Sam 13 who takes matters into his own hand and therefore only reigns for two years, David is compared to the faithful Saul of 1 Sam 11 who interacts with the men of Jabesh-Gilead after he is anointed as king.

Qualified by his character. The allusions to David's flight and exile in the latter half of 1 Samuel as well as the way he acts in vv. 1-11 show that, in contrast to Abner and Ish-boshet, he will not selfishly seize the throne for himself. Instead, he humbly waits upon God to give it to him. In spite of the way Saul treated him, he does not seek vengeance but repays evil with good and commends those who showed

Qualified by his personality. In contrast to the passive and weak Ish-boshet who is controlled by Abner, David is a man of action who takes initiative at the proper time. ${ }^{79}$

\footnotetext{
${ }^{79}$ It is interesting to compare David's relationship with YHWH to Ish-boshet's relationship with Abner. While Abner takes the initiative and exerts complete control over Ish-boshet, YHWH does not control David or make him king by force. Instead, it is David who takes the initiative and allows himself to be guided by YHWH.
} 
Qualified by his experience. The parallels between the experiences of David and those of Israel's founding fathers Abraham and Jacob and of the nation itself suggest that David is recapitulating the history of the very nation he is to rule.

\section{Foundational elements of David's Kingship}

Divine Guidance. It is significant that the chapter which recounts the beginning of David's kingship opens with David inquiring of YHWH. From the very outset David's kingship is thus associated with divine guidance. The author highlights the positive effects this has by contrasting David's experience in 2 Sam 2:1-4 with his experience in 1 Sam 27:1-7 where he does not inquire of YHWH. Without divine guidance, David leaves the land in fear and settles in a foreign city that is later captured and burned to the ground by the Amalekites. With divine guidance, David returns to the land and settles in a city of Judah where he is anointed king and dwells in peace and safety. Neither Ish-boshet nor Abner, on the other hand, inquire of YHWH at all, instead taking matters into their own hands. Ish-boshet's kingship is thus based on selfish human ambition instead of the divine will.

Obedience to the Divine Will. David does not just seek divine guidance but also obeys the divine command, going up to Hebron in Judah just as YHWH told him to. Abner and Ish-boshet, on the other hand, disobey the divine will by refusing to recognize the divinely chosen David as king.

Justice. A direct result of David's obedience to and faith in YHWH is that he is able to discern between good and evil and thus to pronounce just judgments and administer true justice that is not influenced by personal feelings. In spite of the way Saul 
treated him, David condemns the lying Amalekite who claimed to have killed Saul, but commends the men of Jabesh-Gilead who showed

Unity. In contrast to Abner and Ish-boshet who provoke disunity and strife through the creation of a counter kingdom, David works toward a united kingdom as his message to the men of Jabesh-Gilead shows.

Freedom of choice. It is significant that David does not attempt to bring about this unity by force. Instead of threatening the men of Jabesh-Gilead and forcing them to accept him as their king, David simply informs them that he has been made king over Judah and offers himself as a covenant partner, leaving it up to them how they will respond. In contrast, Abner imposes Ish-boshet upon Israel, leaving them no choice but to accept him as their king.

Focus on YHWH and the covenant. In light of the central role that David plays in 2 Sam 2:1-11 it is significant that he does not place the primary focus on himself but rather on YHWH. He not only inquires of him at the beginning of the passage, but also mentions YHWH before himself in his message to the men of Jabesh-Gilead. His words reveal that he considers YHWH to be the true source of blessing and strength and the ultimate giver of חֶֶ?. By alluding to Exod 34 in v. 6, David also reminds of YHWH's role as Israel's covenant partner. This suggests that the covenant relationship between YHWH and Israel is a foundational element of David's kingship. On the other hand, no mention of YHWH or the covenant is made by Abner and Ish-boshet. Their focus is on self.

Humility and proper self-assessment. David's focus on YHWH reveals his humility. In spite of the fact that he holds the highest office in the nation, he does not 
make himself the center of attention. At the same time, David closely identifies himself with God, promising to deal with the men of Jabesh-Gilead in the same way as he wished for God to do. Though he also presents himself as a covenant partner to the Jabesh-

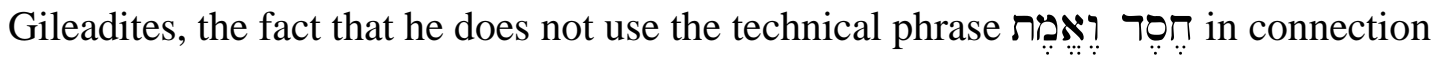
with himself reveals that he knows his place in relation to God. Abner's act of installing Ish-boshet as king, on the other hand, reveals his lack of humility and proper selfassessment. Instead of humbly accepting YHWH's choice of David as Saul's successor, Abner decides to play god and choose a king as well. Like David he thus acts like God. The crucial difference is that David recognizes that he is not God, causing him to act in harmony with God's law, while Abner makes himself god and blatantly disregards the divine will. This is the ultimate self-deception.

$70 \%$ and repaying good with good. One of the most prominent elements of David's kingship in 2 Sam 2:1-11 is the concept of חֶֶ. The importance of this element is emphasized by (1) the fact that the term occurs twice in vv. 5 and 6, (2) the fact that the term is mentioned in the central section of the passage and (3) the fact that the term is associated with David's first recorded royal act. David, who according to 1 Sam 20 is himself a man of חֶֶ, commends the men of Jabesh-Gilead for showing חֶֶ to Saul and wishes for YHWH to show חֶֶ to them in return. Thus, David's kingship is based on relationships of mutual חֶֶ between YHWH, king and people. In stark contrast, Abner and Ish-boshet do not show חֶֶ? to YHWH, David, Saul or the people. 


\section{The Purpose of David's Kingship}

Return to the Edenic model. The parallels between Eden and the Promised Land as well as the possible association of Hebron with the garden of Gen 2-3 raise the possibility that David's return to the land at the beginning of 2 Sam 2 should be understood as a return to Eden, so to speak. This would in turn link David's kingship with that of the first humans who rule over the earth from the garden paradise. In light of this possibility it is interesting that David wishes YHWH's blessing upon the men of JabeshGilead and promises to do good to them. The fact that David commends the men of Jabesh-Gilead for acting like God by showing חִֶ? further suggests that David's kingship may be connected to the restoration of the image of God in man. In this way the return to the garden would be fully realized in every dimension.

While David seems to be associated with Adam in his unfallen state in Gen $1-$ 2, Ish-boshet's name and behavior remind of the fallen Adam in Gen 3. Like Adam, Ishboshet disobeys the divine command and seeks to rule on his own terms. He thus becomes a new "man of shame" dwelling outside of the land.$^{80}$ This once again underscores that Ish-boshet's kingship is flawed.

Salvation for Israel. While Ish-boshet's kingship is connected to sin and disobedience, David's kingship seems to be associated with the sanctuary that is designed to provide a solution to the sin problem. It does not appear accidental that David begins his reign at Hebron, a city of refuge as well as a place of worship possibly connected to the original garden sanctuary. The fact that Hebron was given to the priests, the sons of

${ }^{80}$ Notice that the very next episode after Ish-boshet leaves the land describes a deadly conflict between brothers, reminding of Cain's murder of his brother Abel in Gen 4. 
Aaron, who work at the sanctuary suggests that David's kingship also involves a priestly aspect. This would make sense, since the work of the priests played an important role in the restoration of mankind into the image of God.

Finish the conquest. Such a restoration and a return to the Edenic model are only possible when the conquest of the land that Israel failed to fully accomplish during the time of Joshua and the judges is finally completed. It is thus not surprising that this task appears to be another important aspect of David's kingship. This can be seen in particular through the allusions to the experiences of Israel, in particular in Num 13 and Judg 1. Like Israel, David goes up to the land and needs sons of valor with strong hands to fight the battles of YHWH. Abner and Ish-boshet, on the other hand, are not concerned with finishing the conquest so that Israel may live in peace. Instead of fighting against Israel's enemies, their selfishness causes Israel to fight against itself.

\section{Samuel 2:12-32}

Text

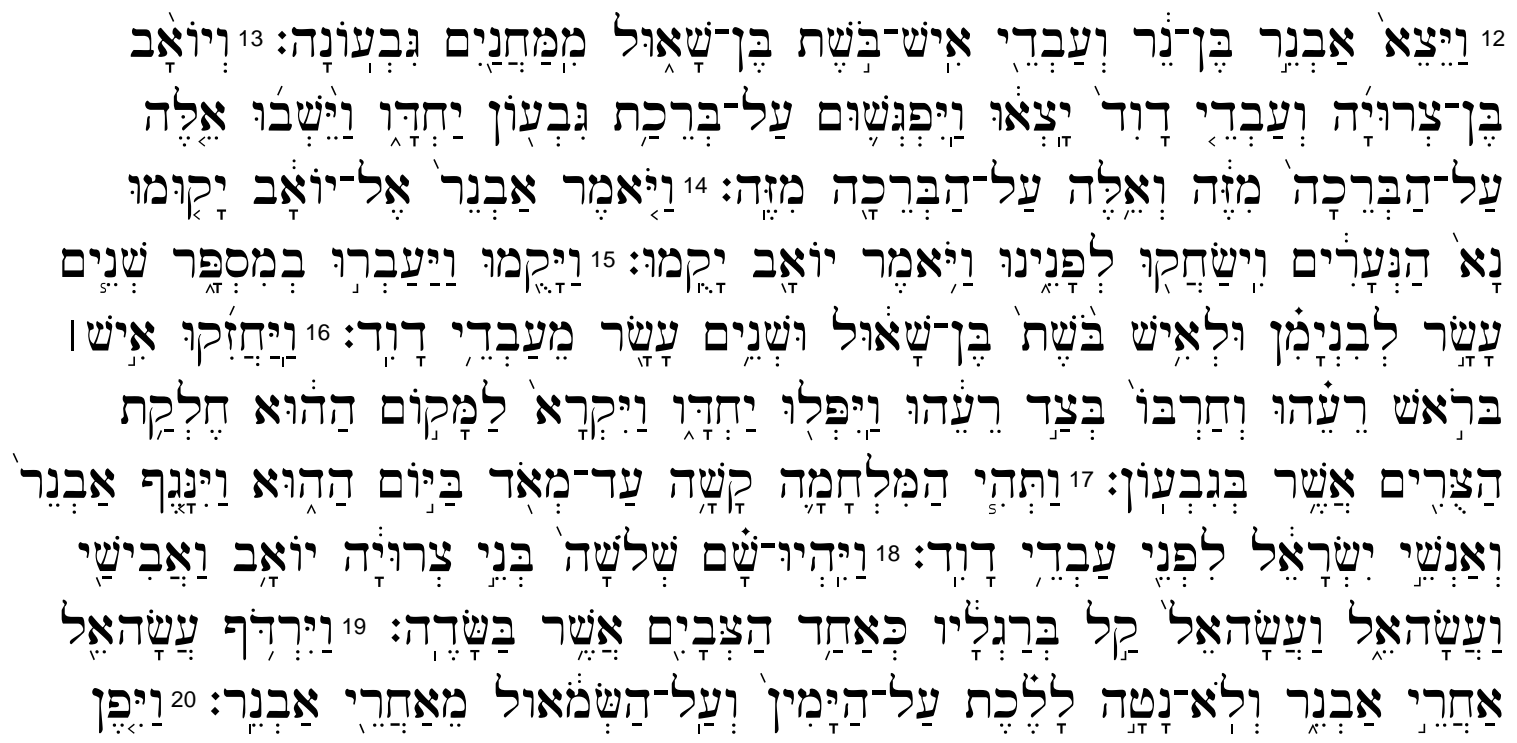




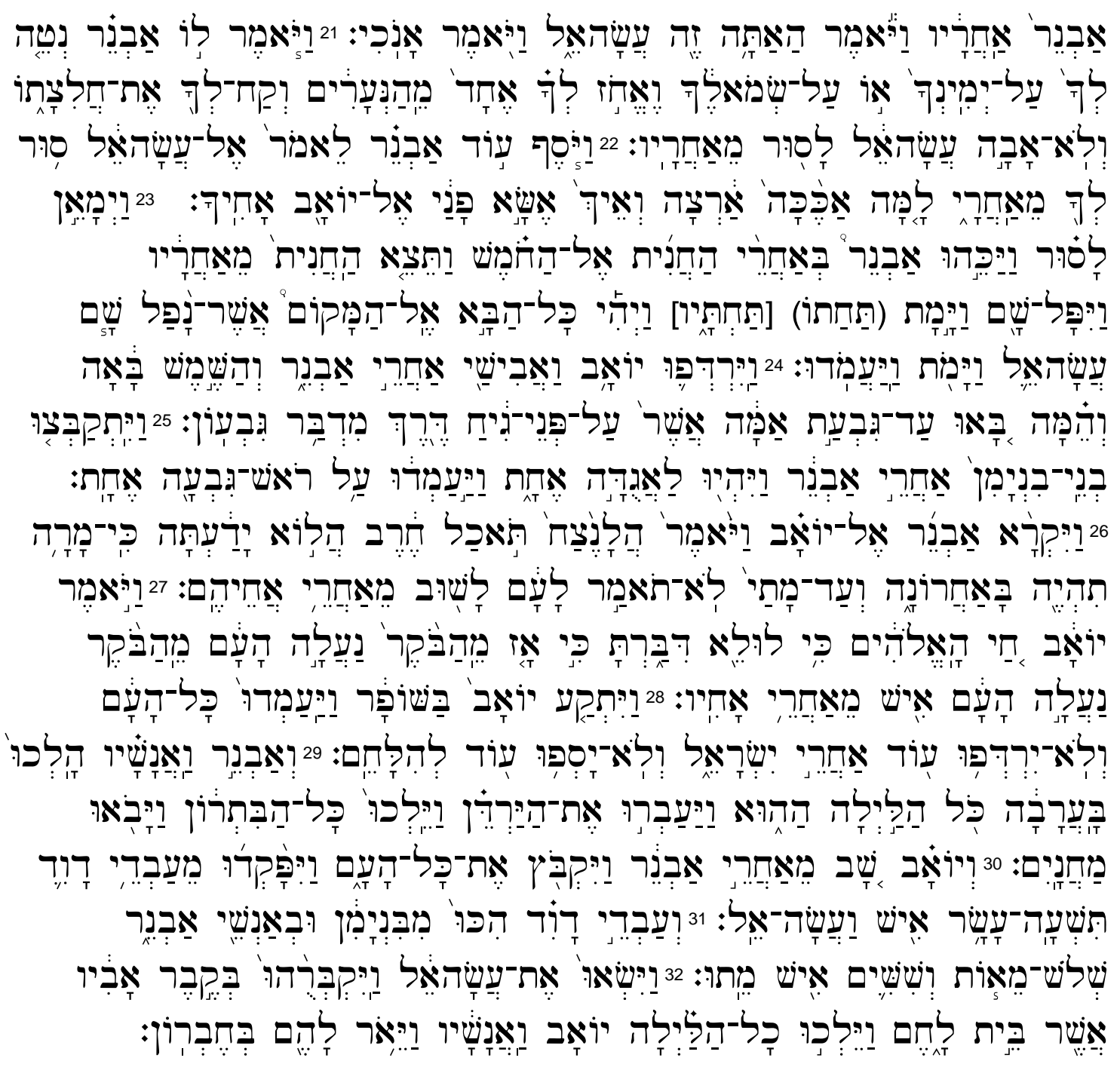

\section{Translation}

${ }^{12}$ Then Abner, the son of Ner and the servants of Ish-boshet, the son of Saul, set out from Mahanaim to Gibeon. ${ }^{13}$ As a result, Joab and the servants of David set out. And they met each other by the pool of Gibeon and sat down, these on this side of the pool and those on that side of the pool. ${ }^{14}$ Then Abner said to Joab: "Let the young men now arise and play before us." And Joab said: "Let them arise." ${ }^{15}$ So they arose and passed over by number, twelve for Benjamin and for Ish-boshet, the son of Saul and twelve from the servants of David. ${ }^{16}$ Then each one of them seized his fellow by the head and his sword in his fellow's side; so they fell together. Therefore that place was called Helkath-hazzurim, which is in Gibeon. ${ }^{17}$ Now it came to pass that the battle was very heavy on that day and Abner was beaten and the men of Israel before the servants of David. ${ }^{18}$ Now the three sons of Zeruiah were there: Joab and Abishai and Asahel. And Asahel was as swiftfooted as one of the gazelles which is in the field. ${ }^{19}$ And Asahel pursued after Abner and 
in going he did not turn to the right or the left from following Abner. ${ }^{20}$ Then Abner turned around and said: "Is that you, Asahel?" And he said: "It is I." ${ }^{21}$ Then Abner said to him: "Turn to your right or your left and seize one of the young men and take his equipment." But Asahel was not willing to turn aside from following him. ${ }^{22}$ So Abner said again to Asahel: "Turn aside from following me. Why should I strike you to the ground? How could I lift up my face to your brother Joab?" ${ }^{23}$ But he refused to turn aside. So Abner struck him in the belly with the butt of the spear so that the spear came out of his back. And he fell there and died instead of him. Now it came to pass that all who came to the place where Asahel had fallen and died, stood still. ${ }^{24}$ But Joab and Abishai pursued after Abner. As the sun was going down they came to the hill of Ammah which is before Giah by the way of the wilderness of Gibeon. ${ }^{25}$ The sons of Benjamin gathered behind Abner and they became one troop and stood on top of a certain hill. ${ }^{26}$ Then Abner called to Joab and said: "Shall the sword devour forever? Do you not know that it will be bitter in the end? How long will you then not tell the people to turn back from following their brothers?" ${ }^{27}$ But Joab said: "As God lives, if you had not spoken, surely from the morning the people would have gone up, each from following his brother. ${ }^{28}$ Then Joab blew the trumpet and all the people stood still and no longer pursued after Israel nor did they continue to fight anymore. ${ }^{29}$ Then Abner and his men went through the Arabah all that night and passed over the Jordan and walked through all of Bitron and came to Mahanaim. ${ }^{30}$ And Joab returned from following Abner. And when he had gathered all the people, there were missing from the servants of David nineteen men and Asahel. ${ }^{31}$ But the servants of David had struck down of Benjamin and Abners men: 360 men died. ${ }^{32}$ Then they picked up Asahel and buried him in his father's tomb which was in Bethlehem. And Joab and his men walked all night and the light dawned on them in Hebron.

\section{Delimitation}

Though some commentators see this second literary unit in 2 Samuel 2 as beginning with v. 8 , it has already been shown above that vv. 8-11 are more closely connected to vv. 1-7 than to vv. $12-32 .{ }^{81}$ Further reasons for taking v. 12 as the starting point of this literary unit are: (1) the introduction of new characters such as Joab and the servants of Ish-boshet and David, respectively, in vv. 12 and 13, (2) the change of location from Hebron and Mahanaim to Gibeon and (3) the fact that vv. 12 and 13 serve

\footnotetext{
${ }^{81}$ Those who see the unit as beginning with v. 8 include Brueggemann, First and Second Samuel, 221; Vannoy, 1-2 Samuel, 274 and Robinson, Let Us Be Like the Nations, 160. Most commentators, however, see v. 12 as the starting point.
} 
as the counterpart to the conclusion of the unit in vv. 29-32 insofar as the two armies leave their respective home bases at the beginning of the story and return there at the end. ${ }^{82}$ This symmetry between vv. 12-13 and 29-32 also argues against extending the unit to 3:1 as some commentators suggest. ${ }^{83}$ Instead, this verse seems to function as a transitional statement looking both back to what happened in chapter 2 as well as forward to what will unfold in chapter 3. For these reasons it seems best to view this second literary unit as comprising vv. $12-32 .{ }^{84}$ This conclusion is further supported by the structure of the unit which will be examined next.

\section{Structure}

The episode in 2 Sam 2:12-32 consists of five scenes that are arranged in concentric fashion:

A Introduction: Armies move to Gibeon (12-13a)

B First encounter at a pool (13b-17) X Encounter between Abner and Asahel (18-24a)

B' Second encounter at a hill (24b-28)

A' Conclusion: Armies return home (29-32)

The story is framed by the movements of Abner's and Joab's forces to Gibeon in scene A and back to their home bases in scene A'. Both scenes mention Joab (vv. 13, 30,

${ }^{82}$ Arnold, $1 \& 2$ Samuel, 435: "The account of the civil war...is held together literarily by the march of the generals with their armies from their respective capitals to Gibeon $(2: 12-13)$ and by their return after the conflict (2:29-32)."

${ }^{83}$ See e.g. Vannoy, 1-2 Samuel, 274; Anderson, 2 Samuel, 41; Bergen, 1,2 Samuel, 301 and vom Orde, Das zweite Buch Samuel, 44.

${ }^{84}$ This view is shared by the great majority of commentators. 
32), Abner (vv. 12, 29, 30, 31), the servants of David (vv. 13, 30, 31), as well as the town of Mahanaim (vv. 12, 29). Furthermore, the scenes are connected by the concept of light,

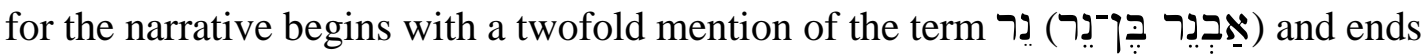

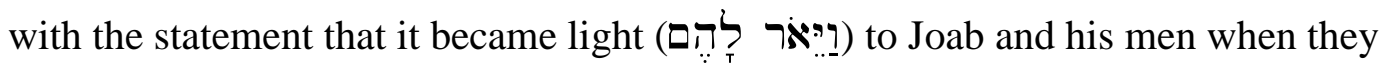
reached Hebron.

Within this outer frame are two scenes featuring an encounter between the two parties at a specified location related to Gibeon, namely the pool of Gibeon (v. 13b) and the hill of Ammah that is before Giah by the way of the wilderness of Gibeon (v. 24). Both scenes open with the parties facing each other (vv. 13b and 24-25). This is followed in both cases by a dialogue between Abner and Joab (vv. 14 and 26-27) that is initiated

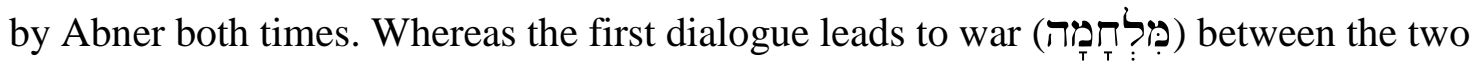
parties (v. 17), they cease to fight $($ ל לחָ $)$ ) as a result of the second dialogue (v. 28). Further terminological connections between the two scenes include the terms

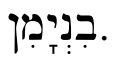

This leaves the central scene in vv. 18-24a. It consists of three main parts, namely a narrative introduction (vv. 18-20a) and conclusion (vv. 23b-24a), that frame the central dialogue between Abner and Asahel (vv. 20b-23a). In both the introduction and the conclusion the three sons of Zeruiah are mentioned. While in the introduction Joab and Abishai are passive and Asahel pursues (רדברָ) Abner, these roles are reversed in the

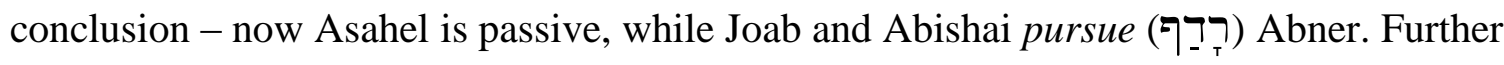
contrasts that connect the two parts are: (1) Whereas according to v. 18 Asahel was swift of foot, in v. 23 everyone who passed Asahel's corpse stood still and (2) whereas Abner 
turned around to speak to Asahel in v. 20, he killed him in v. 23 - quite possibly without facing him. ${ }^{85}$

The structure of the episode can thus be diagrammed as follows:

Scene $1 \quad$ A Introduction: Armies move to Gibeon (12-13a)

Scene 2 B First encounter at the pool of Gibeon: Dialogue between Abner and Joab - fighting begins (13b-17)

Scene $3\left\{\begin{array}{r}\text { C Narrative: } 3 \text { sons of Zeruiah - Asahel pursues Abner - } \\ \text { Asahel swift (18-19) } \\ \text { D Abner turns around and speaks to Asahel (20) } \\ \text { E Abner to Asahel: Turn aside (21a) } \\ \text { F Asahel refuses to turn aside (21b) } \\ \text { E' Abner to Asahel: Turn aside (22) } \\ \text { F' Asahel refuses to turn aside (23a) } \\ \text { D' Abner does not turn around and kills Asahel (23b) } \\ \text { C' Narrative: } 3 \text { sons of Zeruiah - Joab + Abishai pursue Abner - } \\ \text { all stood still (23c-24a) }\end{array}\right.$

Scene 4 B' Second encounter at a hill near Gibeon: Dialogue between Abner and Joab - fighting ends (24b-28)

Scene 5 A' Conclusion: Armies return home (29-32)

The arrangement especially highlights the tragic encounter between Abner and Asahel at the center of the passage which is characterized in particular by Abner's

${ }^{85}$ Morrison, 2 Samuel, 42: „Just as Absalom's famous hair becomes the instrument of his defeat (14:26 and 18:9), so Asahel's speed leads to his downfall. The description of his death leaves the impression that Abner just stopped running and the tenacious Asahel ran into the butt of Abner's spear." Cf. Fokkelmann, Throne and City, 55: "With unexpected reverse impact - Abner probably did not turn around while he was doing it, the surprise is complete - Asahel is given a lesson in 'do it or else!'." 
repeated but futile appeals to Asahel to turn aside and the latter's persistent refusal to do so that leads to his death at the hands of a fellow Israelite who knows him personally. In this way, not only Asahel's stubborn foolishness as well as Abner's helpless inability to stop the war he initiated is emphasized but also the senselessness of the entire conflict, for just like the opposing parties in the larger narrative, in the end neither Asahel nor Abner achieve their objective. Instead, both sides lose: Asahel dies instead of killing Abner, while Abner kills Asahel instead of sparing him. The tragic character of the entire scene stands in stark contrast to the hopeful and encouraging outlook of the central scene in the previous literary unit (2:4b-7) ${ }^{86}$ In particular the differences between David on the one hand and Asahel and Abner on the other are striking. Whereas David reaches out with a word of blessing and encouragement to those he could consider enemies, Asahel is bent on killing his enemy Abner. While David wishes YHWH's blessing on those who showed to the one that pursued and sought to kill David, Abner is pursued and eventually kills the one who sought to kill him. And in contrast to David, who is able to freely do what he wants, namely do good to the men of Jabesh-Gilead, Abner finds himself in a situation where he is almost forced to do what he does not want, namely kill his pursuer. ${ }^{87}$ The comparison reflects negatively on both Asahel and Abner and by

\footnotetext{
${ }^{86}$ Brueggeman, First and Second Samuel, 223-24: "The contrast between the narrative of verses 4b-7 and verses 8-32 is powerful. David proposes to be a bearer of hesed (vv. 4b-7), but that narrative of hesed toward Jabesh-gilead stands isolated without a future. The immediate future belongs to the AbnerJoab conflict (vv. 8-32). The juxtaposition of hesed and 'sword' invites a reflection on power and legitimacy, on the reality of blood in the midst of power and the limits of the strategic shedding of blood. The juxtaposition raises the question of how and in what way the vicious cycle of destructive power can ever be broken."

${ }^{87}$ Note also the contrast between Asahel and the men of Jabesh-Gilead. While the latter show to a fellow Israelites and as a result are blessed, the former pursues and seeks to kill a fellow Israelite and as a result is killed himself.
} 
extension on both of the opposing parties in the narrative. Conflict and strife between fellow Israelites are thus cast in a negative light and shown to be in opposition to the foundational elements of blessing, חְֶ? and unity which characterize David's kingship.

\author{
Close Reading
}

Two kings and their respective domains have been presented in the first eleven verses of 2 Samuel 2. The kingdom that was united under Saul is thus now divided. This naturally raises the question how the two sides will relate to each other. Will they be content with the situation or will either David or Ish-boshet seek to take the whole kingdom? And if so, how will they go about it? Will they fight for the supremacy? Will there be civil war? And if so, what will be the outcome of such a war? And: what implications can be drawn from the actions of the two sides and their interaction with each other with regard to the kingships of Ish-boshet and, in particular, David? It is these questions that loom large at the outset of the narrative in vv. 12-32.

\title{
Verses 12-13a
}

\section{Verse 12}

The story opens on an ominous note with almost identical descriptions of troop movements on both sides. ${ }^{88}$ As in v. 8 Abner takes the initiative on Ish-boshet's side,

\footnotetext{
${ }^{88}$ The symmetry that is achieved by these almost identical descriptions continues throughout the narrative unit and underscores how similar the two sides are. As the remainder of the story will demonstrate, they are mirror images of each other: both go out led by a general, both sit down on one side of the pool, both choose twelve young men, both groups of twelve die, both sides fight, both stop fighting, both have losses and both march all night on their way home. These parallels stand in striking contrast to the differences between the sides that were highlighted in vv. 1-11. One reason for this change may very well be the change in leadership on David's side from David to Joab. In contrast to David, Joab appears to be very much like Abner, taking matters into his own hands instead of seeking to do the will of YHWH. As a result the parties become very much alike, with both seeking to kill fellow Israelites. This contrast once
} 
going out with Ish-boshet's servants from Mahanaim to Gibeon. Though no explanation is given for Abner's move, both the term $\boldsymbol{N}_{T}^{3}$, as well as the mention of Ish-boshet's servants suggest that this was some kind of military campaign, possibly with the intent of taking Gibeon from the Gibeonites in order to make it the capital city of Ish-boshet's kingdom. ${ }^{89}$ Such a move would not have been surprising given that Gibeon was not only a city in Benjamin, Saul's home tribe, but also "a great city, like one of the royal cities" (Josh 10:2) which Saul had attacked in the past (2 Sam 21:1-14). ${ }^{90}$ Furthermore, the city was located much more centrally than Mahanaim and was only a few miles from the border of David's territory. ${ }^{91}$ If the tabernacle was already located there at that time this would have made Gibeon even more attractive as the new capital of the Saulide dynasty. ${ }^{92}$ Thus Abner's operation may quite possibly have been a strategic move both from a political as well as from a religious perspective.

This is further supported by the fact that, like Hebron, Gibeon was one of the cities given to the sons of Aaron (Josh 21:9-19). Interestingly, these cities are presented

again highlights David's attitude of seeking YHWH's will and showing that is so foundational for the nature of his kingship and sets his kingship apart from Ish-boshet's.

${ }^{89}$ Leithart, A Son to Me, 184; Anderson, 2 Samuel, 42; McCarter, II Samuel, 94; Birch, "First and Second Books of Samuel," 1216. That this was indeed a military operation is further supported by the fact that Abner is once again called "the son of Ner" in v. 12, a designation that prior to 2 Sam 2 was used only in 1 Sam 14 and 26 and is therefore strongly connected to Abner's function as commander of Saul's forces.

${ }^{90}$ Leithart, A Son to $\mathrm{Me}, 185$.

${ }^{91}$ A number of scholars believe that Abner's move to Gibeon was clearly intended as a challenge to David. See e.g. Vannoy, 1-2 Samuel, 276-77 and Dale R. Davis, 1 Samuel: Looking on the Heart, FBC (Tain, Scotland: Christian Focus Publications, 2010), 35.

${ }^{92}$ According to $1 \mathrm{Ki} 3: 4$ and $2 \mathrm{Chr} 1: 3$ the tabernacle was already at Gibeon at the beginning of Solomon's reign. The move from Nob, where it was previously located (1 Sam 21:2-10), to Gibeon may have taken place after Saul's slaughter of the priests at Nob (1 Sam 22:6-23), but this is not certain. See Leithart, A Son to Me, 185. 
in two lists, with Hebron heading the list of cities from Judah and Simeon and Gibeon heading the list of cities from Benjamin. Thus, Abner's move may have been intentionally designed to parallel David's move to Hebron. However, while David inquired of the Lord before moving into the land and peacefully going up to Hebron which would become the capital city of his kingdom, no such inquiry is reported with regard to Abner as he and his troops move into the land and advance towards Gibeon with the possible intent of making it the new capital of Ish-boshet's realm. Furthermore, as Abner's first reported action after the installment of Ish-boshet as king over Israel, his military excursion to Gibeon also stands in marked contrast to David's first reported action as king which was to send messengers with a word of blessing to the men of Jabesh-Gilead. David's action is designed to bring peace and unity to Israel. Abner's action, on the other hand, leads to strife and disunity between brothers. These contrasts confirm the impression already gained in the first literary unit, namely that Ish-boshet's kingship is based on selfish ambition without any concern for divine guidance. ${ }^{93}$

Verse 13a

Yet Abner and the servants of Ish-boshet are not the only ones on the move at the beginning of this literary unit. According to v. 13 Joab, the son of Zeruiah, and the

\footnotetext{
${ }^{93}$ If Abner indeed went out with the intent of attacking Gibeon as Saul had done, this would also provide another contrast to David. Interestingly, David is the subject of four of the five occurrences of immediately preceding 2 Sam 2:12 and three of those references are about David going out with the Israelite forces to fight against the Philistines (1 Sam 18:5, 13; 19:8). This underscores what was already mentioned above, namely that David is concerned about finishing the conquest. Abner, on the other hand, does not go out against Israel's enemies but against former enemies of Israel who had become part of the Israelite community based on the covenant that Joshua had made with them in Josh 9. Abner's going out against Gibeon would thus not only show his disregard for that covenant and the oath that the leaders of Israel had sworn by the Lord (Josh 9:15, 17) but also his lack of concern for finishing the conquest.
} 
servants of David also go out. ${ }^{94}$ Though neither their point of departure nor their

destination is mentioned, the similar wording to v. 12 suggests that their going out is also

a military endeavor. This does not bode well for what is to come. ${ }^{95}$

\title{
Verses 13b-17
}

Verse $13 b$

The two sides meet at the pool of Gibeon. The rare verb ָำ that is used here

occurs only five times previously in the Old Testament: two times in Gen $32-33$

(meeting of Jacob and Esau), two times in Exod 4 (meetings of YHWH and Moses and

Aaron and Moses, respectively) and one time in 1 Sam 25 (meeting of David and

Abigail). ${ }^{96}$ In light of the allusions to the Jacob and Abigail narratives in the previous

\begin{abstract}
${ }^{94}$ Interestingly, neither of the two kings makes an appearance here or anywhere else in the story. Instead, two other individuals lead the two armies. That Abner is in charge of Ish-boshet's forces is not surprising, since he had the same position during Saul's reign and v. 8 already demonstrated that the real power in Ish-boshet's kingdom lies with Abner rather than with the actual king. While Ish-boshet's absence is thus easily explained by his passivity and Abner's dominance and experience, David's absence is more surprising, not only because he has been presented as an active individual in vv. 1-11 but also because he had led his men as well as the forces of Israel on military campaigns in the past. In this case, however, a certain Joab is leading the troops. Though Joab has been mentioned once before back in 1 Sam 26, nothing is known about him at this point in the larger narrative, except that he is a son of Zeruiah and the brother of Abishai. His sudden and surprising appearance raises a number of questions: Is he the official commander of David's troops? If so, is he acting on orders of David when he goes out in v. 13 or not? And if not, is David aware of the fact that he goes out? The story does not provide answers to these questions, making it difficult to determine what role David played in the movement of his troops in v. 13. Regardless of how David's absence should be interpreted, however, it appears significant that David, who was so active in the previous literary unit, remains passive here and does not go out. At the very least, his surprising absence distances him from the events of this literary unit.
\end{abstract}

${ }^{95}$ This impression is reinforced by the fact that the only time Abner, the son of Ner, and Joab, the son of Zeruiah were previously mentioned in the same narrative in the Samuel books was in 1 Sam 26, where Joab was first introduced as the brother of Abishai. In that story, Abner is commanding the forces of Saul who is seeking to kill David, while Abishai wants to kill Saul. Hence, both Abner and Joab are associated with individuals who seem to have no scruples eliminating a fellow Israelite.

${ }^{96}$ Significantly, these three stories are connected to each other through shared vocabulary and

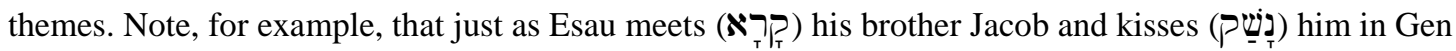

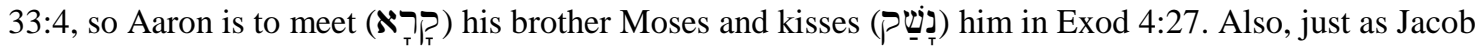


literary unit, the verbal link to Gen $32-33$ and 1 Sam 25 does not seem coincidental. ${ }^{97}$

Like the present narrative both of the earlier stories feature a meeting between two related

parties just after one of the parties has returned to Israelite territory from exile. ${ }^{98}$ In each

case there is a threat of death as one party approaches with hostile intentions yet in

contrast to 2 Sam 2 the earlier two situations are resolved peacefully through kindness,

forgiveness, trust in God, obedience to His Word and a willingness to recognize him

whom YHWH has chosen. At the very beginning of the conflict in 2 Sam 2 it seems that

the attentive reader is reminded of a way it could have been resolved peacefully.

Though the situation will soon deteriorate significantly, here at the outset it is still very much unclear how things will develop. In stark contrast to the violence and mayhem that will ensue shortly, the beginning of the scene is characterized by a surprising, almost eerie calm coupled with great symmetric order, for instead of immediately attacking one another, as one might expect, the two parties sit down on either side of the pool. ${ }^{99}$ As

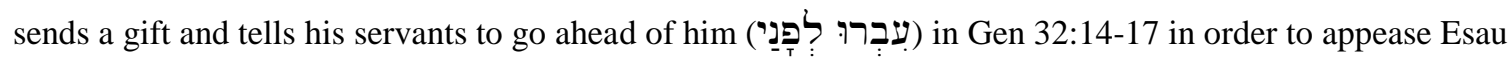

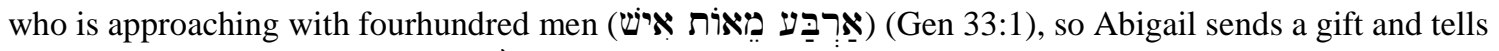

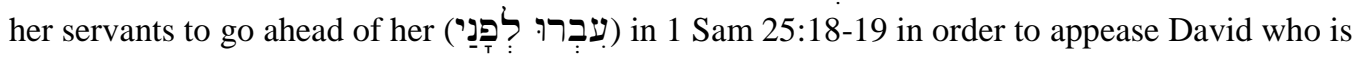

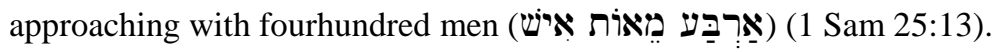

${ }^{97}$ There may also be a connection to the story in Exod 4, given that as in 2 Sam 2 (vv. 26-27) and Gen 32 - 33 there is a meeting between brothers as one brother returns from exile in a foreign land.

${ }^{98}$ While the meeting in Gen $32-33$ is between literal brothers, the meeting in 1 Sam 25 is between fellow Judahites. In 2 Sam 2, the meeting is between fellow Israelites who are called brothers (vv. 26-27).

${ }^{99}$ In light of the just mentioned parallels between 2 Sam 2 and the Jacob and Abigail narratives, it

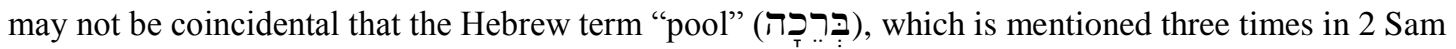

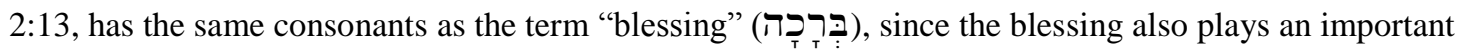
role in both Gen 32-33 and 1 Sam 25. The verbal link may serve as a subtle hint that as in these earlier stories the conflict in 2 Sam 2 is to be understood as revolving around the blessing and the question who has been chosen by YHWH to receive it. In contrast to the two earlier stories where the blessing is offered by one party to the other (Gen 32:27, 30;33:11; 1 Sam 25:14, 27,33), in the present narrative both parties appear to be sitting on either side of the blessing, so to speak, raising the question whether they will be able to obtain it. As both Gen 32-33 and 1 Sam 25 show, the blessing is not obtained by human efforts of 
already noted above, the symmetry hints at the similarity between the two groups who not only belong to the same people but also exhibit the same attitude towards the other side as the narrative continues. At the same time, the unity displayed through the mirroring actions of the two parties provides a striking and ironic contrast to the division and lack of agreement seething beneath the surface. Indeed, even now the tension is palpable as the reader wonders whether the arrangement around the pool is a first sign of de-escalation or simply the final calm before the storm.

\section{Verse 14}

Once more it is Abner who makes the first move, proposing a contest between the two parties. Whether he simply had some kind of game or mock contest in mind or whether this was to be a representative battle to the death is difficult to determine. Much depends on how the verb means "to play" or "to amuse," leading some commentators to believe that Abner was only proposing a tournament that got out of hand, recent scholarship largely agrees that it is used euphemistically here to denote a struggle to the death. ${ }^{100}$ Whatever the case may be, the word choice is significant for at least two reasons. First, as Leithart has noted,

deception or force, but can only be received as a gift by refusing to help oneself with one's own hand and trusting and waiting on YHWH instead. At the same time, the link to 1 Sam 25 may serve as a reminder that David has already received the blessing which is closely connected to his kingship (1 Sam 25:27-31). This not only once again highlights the superiority of David's kingship, since no such blessing is ever bestowed on Ish-boshet, but also suggests that there is no point in fighting for the blessing. Instead, the side of Abner and Ish-boshet must ally themselves with David and acknowledge his kingship in order to become partakers of the blessing.

${ }^{100}$ See e.g. Anderson, 2 Samuel, 43; Birch, "First and Second Books of Samuel," 1216; Brueggemann, First and Second Samuel, 222; McCarter, II Samuel, 95; and Fokkelman, Throne and City, 43-44. Those who favor the former view include Hertzberg, I \& II Samuel, 251; Leithart, A Son to Me, 185; and vom Orde, Das zweite Buch Samuel, 47. 


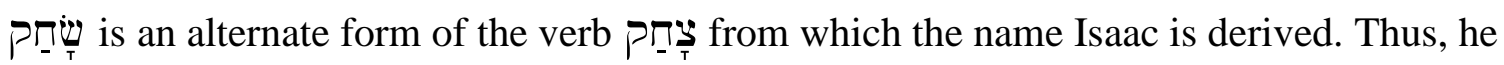
suggests that the two sides were "Isaacing" in an effort to "determine who were the true sons of Abraham, a dimension of the contest further symbolized by the fact that each side chose twelve warriors." 101 While the number twelve obviously reminds of the twelve tribes of Israel, it is also associated with Ishmael (Gen 17:20). ${ }^{102}$

Furthermore, according to Gen 21, Ishmael and his mother were sent away from

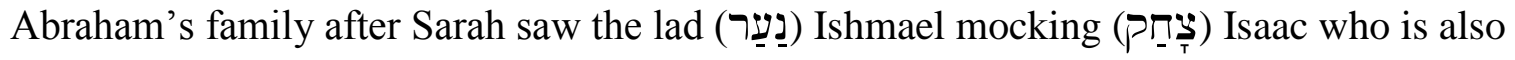

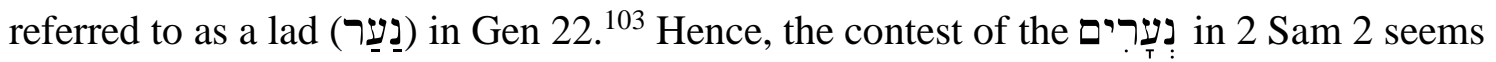
to remind of the conflict between Isaac and Ishmael which revolved around the central issue which one of them is the chosen son of Abraham and why. As the story of Abraham shows, Ishmael is begotten by Abram's maid Hagar because of a lack of faith in God's promise. He is thus the son of human effort who later leaves the family. Isaac, on the other hand, is the chosen son through whom Abraham's line will continue. He is begotten by Abraham's wife Sarah, not through human efforts, but as a result of divine intervention (Gen 21:1). Thus, the chosen son of Abraham is associated with divine election and with waiting patiently and obediently for YHWH to fulfill his promises instead of taking matters into one's own hands. It is precisely this attitude that both parties in 2 Sam 2:12-32 lack, but which the divinely chosen David has repeatedly

${ }^{101}$ Leithart, A Son to $M e, 185-86$.

${ }^{102}$ According to the divine promise given to Hagar, Ishmael was to become the father of twelve princes and would become a great nation (Gen 17:20). See also Gen 25:16.

${ }^{103}$ See Gen 21:9. Ishmael is called פַעַ in vv. 12 and 17-20, while Isaac is referred to in this way in Gen 22:5, 12. 
exhibited on his way to the throne. This once again distances David from the events at Gibeon and shows that the contest at the pool is unnecessary, for David has been chosen by YHWH to be king over Israel - a fact that Abner is well aware of as will become evident in 2 Sam $3 .{ }^{104}$ Hence, what is needed is not a bloody contest between brothers that mocks David's divine election but a humble recognition of the same.

That this is indeed the issue is further highlighted by the fact that the term שָָָָ also reminds the attentive reader of 1 Sam 18:7, the only place where the term occurs previously in 1 and 2 Samuel. There the women of Israel sing and play (שָָָׁ) as David and the Israelite army return from fighting the Philistines. Their song also emphasizes David's superiority over Saul, a fact which Saul in v. 8 explicitly connects with the transfer of the kingship to David announced by Samuel in 1 Sam 15:28. ${ }^{105}$ But instead of acknowledging David's success and superiority, Saul exhibits the same attitude as Abner and his followers in 2 Sam 2. At the same time, the link to 1 Sam 18 reminds of David's concern for finishing the conquest by fighting against Israel's enemies which stands in stark contrast with the scene in 2 Sam 2:12-16. Instead of going out to hold a contest

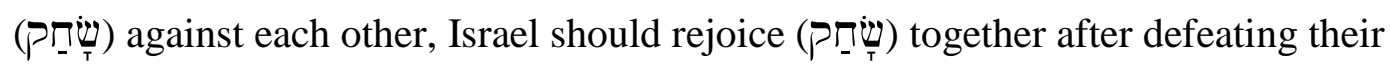
enemies. The term thus appears to serve as another subtle reminder of what Israel's actual task should be, casting Abner's proposal in a negative light. ${ }^{106}$

${ }^{104}$ See 2 Sam 3:17-19.

${ }^{105}$ Bergen, 1,2 Samuel, 201.

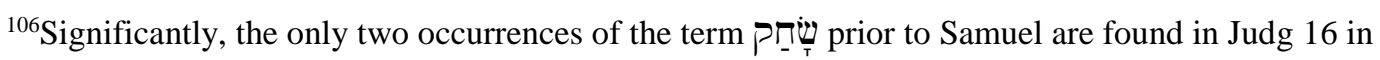
the context of Samson's final battle against the Philistines. Thus all three occurrences of prị prior to 2 Sam 2:14 are found in the context of Israel fighting against their enemies. 
Verse 15

The same point is further emphasized by the wording in v. 15. After Joab accepts Abner's proposal the narrator reports that twelve from each side went over by number

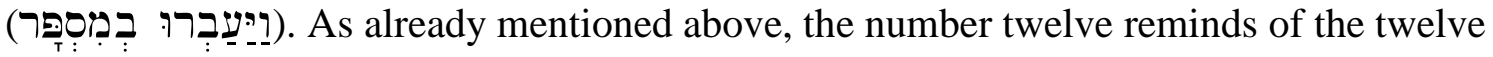
tribes of Israel. ${ }^{107}$ It thus seems as if "both sides are laying claim to the twelve tribes of Israel in its entirety." ${ }^{108}$ Both sides are in effect claiming to be the true Israel. Yet the truth is that they are all Israelites and should not fight against each other but side by side. This is highlighted by the fact that in combination with the verb עָרָר and the expression

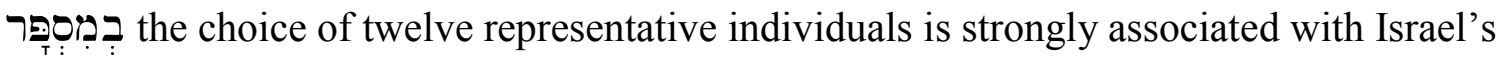
task of crossing over into the land in order to conquer and possess it. Thus, 18 of the 24

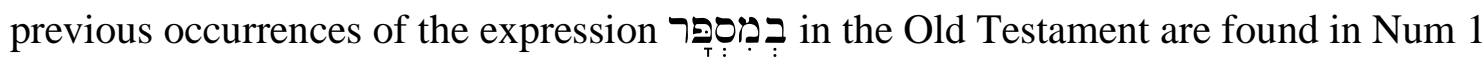
and 3 in the context of the first wilderness census of "all who are able to go to war in Israel" (Num 1:3) that is conducted by Moses, Aaron and twelve chosen men (Num 1:44). Likewise, twelve men are chosen to spy out Canaan in Num 13, who proceed to "pass through" (עָברבר) the land (Num 13:32; 14:7) in preparation for the conquest. And when Israel finally crosses over (עָָבר ) the Jordan into Canaan in Josh 3-4, including "forty thousand equipped for war" (Josh 4:13), once again twelve men are chosen to pick up twelve memorial stones out of the middle of the Jordan (Josh 4:1-9). In light of the fact that David, who has been recapitulating the story of Israel throughout 1 Samuel, has just

\footnotetext{
${ }^{107}$ Polzin, David and the Deuteronomist, 34.

${ }^{108}$ Fokkelman, Throne and City, 44.
} 
returned to the land at the beginning of 2 Sam 2, the combination of terms in v. 15 reminding of Israel's entry into the land at the time of the conquest once again suggest that instead of fighting against each other, all Israel should focus on finishing the conquest.

The wording in the rest of v. 15 is also noteworthy. In light of vv. 12 and 13 one would expect the second half of v. 15 to read: "twelve of the servants of Ish-boshet and twelve of the servants of David." Instead, however, the author notes that there were "twelve for Benjamin and for Ish-boshet, the son of Saul, and twelve of the servants of David." At least two things may be noted here. First, the "absence" of any servants of Ish-boshet is interesting. While the servants of David appear throughout the story, the servants of Ish-boshet are only mentioned at the beginning of the account in v. 12, but then "disappear" as the narrative unfolds. ${ }^{109}$ This "loss" of servants again reflects negatively on Ish-boshet's kingship and provides another striking contrast to the kingship of David. ${ }^{110}$

Second, the mention of Benjamin and the designation of Ish-boshet as "the son of Saul" suggest that the contest at the pool is an attempt to assert the continuing supremacy of the house of Saul and, by extension, the tribe of Benjamin and in that way to legitimize Ish-boshet's kingship. Thus, the first twelve cross over for Benjamin and for Ish-

\footnotetext{
${ }^{109}$ The repeated mention of the servants of David provides yet another connection to 1 Sam 25 , the only time the designation עַבְרָי דָרוד occurred previously in the Old Testament. The mention of David's servants therefore evokes memories of a situation where a conflict was almost settled by military means but in the end David trusted in the Lord to provide justice. This would have been the correct way of dealing with things in 2 Sam 2 as well.

${ }^{110}$ This negative development continues as Abner also deserts Ish-boshet in chapter 3 and Ishboshet's own men kill him in chapter 4 . Thus the kingship of Ish-boshet is destroyed from within.
} 
boshet. ${ }^{111}$ In contrast, the second twelve are simply designated as "twelve of the servants of David" instead of "twelve for David," suggesting that David's kingship does not need such legitimation, since David has been chosen by YHWH himself. ${ }^{112}$ In this way the contrast between the kingships of Ish-boshet and David is once again highlighted.

\section{Verse 16}

As soon as the twenty-four young men have been presented, the contest begins. The opponents seize each other by the head, thrust their swords into each other's side and fall together. The shocking nature of what takes place here is underscored by the term רֶ. that occurs twice in v. 16. These are not strangers but neighbors, i.e. fellow Israelites that are fighting against and killing each other. Their behavior stands in stark contrast to the law which stated that an Israelite was to love his neighbor (רֵ) as himself (Lev 19:18). Within 1-2 Samuel the contest between the רִיעימ also brings to mind the conflict between Saul and his neighbor (רֵֵ) David to whom God had given the kingdom (1 Sam $15: 28 ; 28: 17)$. But instead of accepting the divine verdict, Saul also disobeyed the law and attempted to kill his neighbor. It was this same spirit that led to the contest in 2 Sam 2 and which from the outset characterizes Ish-boshet's kingship. David, on the other hand, kissed and wept with his neighbor (רֵ) Jonathan (1 Sam 20:41) and sent gifts of the enemy spoil to his friends (רֵ) in Judah (1 Sam 30:26). David was fighting the

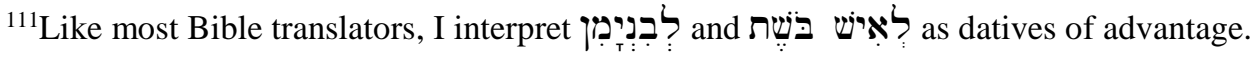

${ }^{112}$ In light of this, it is interesting to note that Joab does not repeat the term שֶׁT in his answer to Abner in v. 14. There is no need for the servants of David to do any "Isaacing" since David has already shown himself to be a true son of Abraham, as pointed out above. 
enemies of Israel and treating his neighbors kindly, in an effort to finish the conquest so Israel could have rest. Those at the pool of Gibeon, on the other hand, were following the example of Saul by fighting against their neighbors, leading to civil war and unrest in Israel. Instead, they should have recognized that the kingdom had been given to their neighbor David and joined him in fighting Israel's enemies.

That the contestants seize each other by the head is quite appropriate in light of what the contest is all about, namely seizing headship over Israel. ${ }^{113}$ As the use of the sword (חרבה) indicates, this goal is to be achieved by violent means. This approach once again contrasts with David's consistent refusal throughout the Samuel books to seize headship in this way. Instead of using the sword, David waits patiently until the kingdom is given to him. Saul, on the other hand, seeks to protect his kingship by means of the sword. He is hunting down David to kill him and has the priests who helped David killed by the sword (חרבב) in 1 Sam 22. Fittingly, in the end he dies by his own sword. It is probably not accidental that the scene in 2 Sam 2:16 shares the four keywords חֶרב, ,

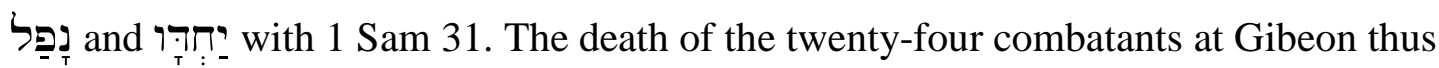
parallels the death of Saul who tried to seize headship by fighting against his neighbor. That the twenty-four kill their neighbor (חרֵֶ) (חרֶ) further with the sword parallels two previous battle scenes where fellow countrymen (רֵֵ) killed each other with the sword (חרוב). In Judg 7 the Midianites turn on each other in this way and in 1 Sam 14

\footnotetext{
${ }^{113}$ Polzin, David and the Deuteronomist, 34 . The head is connected to headship throughout the Old Testament (beginning in Gen 3:15!) and also in Samuel. The taking off of the head in the cases of Dagon (1 Sam 5), Goliath (1 Sam 17), Saul (1 Sam 31) and Ish-boshet (2 Sam 4), for example, visually demonstrated that the headship of these individuals had come to an end.
} 
the Philistines do the same. The parallel to these two previous scenes is not flattering for Israel, for it not only suggests that by fighting against each other they have become like their heathen enemies but also serves as yet another reminder that instead of fighting against each other they should fight against Israel's enemies as they did in Judg 7 and 1 Sam 14.

Verse 17

In spite of the fact that the contest ends in a bloody draw as all twenty-four young men fall together, a very severe battle ensues in which Abner and the men of Israel are beaten before the servants of David. The wording here is once again noteworthy, since

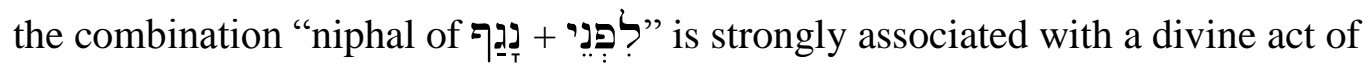
judgment in response to disobedience in the Old Testament, suggesting that this may also be the case in 2 Sam 2:17. According to Deut 28:7 YHWH would cause Israel's enemies

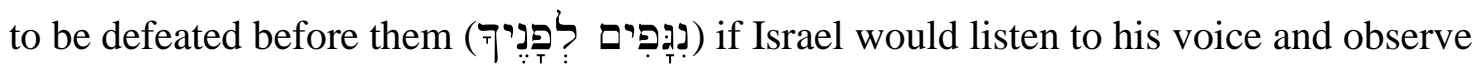
all his commandments. But if they were disobedient to him, he would cause them to be

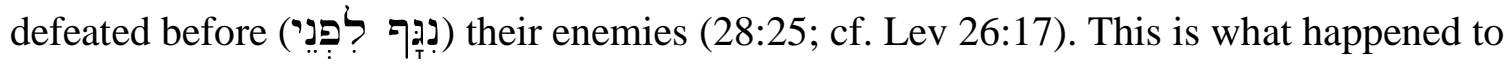
Benjamin when civil war previously broke out in Israel (Judg 20:36) and this seems to be what happens also in 2 Sam 2:17. By making Ish-boshet king, going out with troops to attack Gibeon, and suggesting a contest to determine who were the true sons of Abraham, Abner (and those with him) act in defiance of God's law and his choice of David as 
Saul's successor. Because of this, he and his forces are defeated, with the wording suggesting that their defeat is ultimately at the hands of YHWH himself. ${ }^{114}$

\section{Verses 18-24a}

\section{Verse 18}

Beginning in v. 18 the narrative zooms in on one particular encounter during the battle, namely Asahel's pursuit of Abner. In this way, the conflict is brought down to the personal level. Asahel is introduced alongside his brothers Joab and Abishai as one of the three sons of Zeruiah. ${ }^{115}$ Three sons have been mentioned by name twice before in Samuel. In 1 Sam 17 the three older sons of Jesse follow Saul to the battle against the Philistines. Significantly, it is precisely these three sons that are rejected by God to be king over Israel in 1 Sam 16 and at least in Eliab's case this rejection is due to his heart (1 Sam 16:7). The three sons are thus set in contrast to David who has a different heart (see e.g. 1 Sam 24:6). The difference between them becomes clear in 1 Sam 17. While David trusts fully in God to give the victory over Israel's enemies, his brothers are associated with Saul (1 Sam 17:13) who trusts in human strength and weapons and therefore considers David unfit to go into battle (1 Sam 17:28, 33). Interestingly, the three sons of Zeruiah exhibit the same attitude. This already becomes apparent in 1 Sam 26 (the only previous time Asahel's brothers Joab and Abishai are mentioned in Samuel),

\footnotetext{
${ }^{114}$ This is further supported by the fact that the only previous occurrence of the exact combination

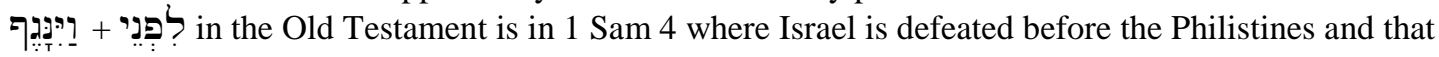
defeat is clearly credited to YHWH (see vv. 2-3). It is also interesting to note that in 2 Sam 2 the name Asahel ("God has done") begins appearing in the narrative directly after the defeat of the men of Israel described in v. 17.

${ }^{115}$ Here we are first introduced to the "brother theme" that plays a significant role in 2 Sam 2 4. It does not seem coincidental that this theme is introduced just as Israel begins to fight against itself.
} 
where Abishai proposes to kill Saul but David refuses to harm him or any of the other Israelites who are pursuing him (1 Sam 26:8-11). In the same way, Asahel acts like Saul by pursuing a fellow Israelite to kill him. In light of this it is not surprising that Asahel's death mirrors the death of Saul and his sons (who go into battle with him just like the three sons of Jesse!) in 1 Sam 31 - the only other place besides 1 Sam 17 where three sons are mentioned by name previous to 2 Sam 2. Like Saul and his sons, Asahel falls in death and is subsequently picked up and carried to his burial. ${ }^{116}$ These parallels to Saul not only place Asahel's pursuit of Abner in a negative light but also set him in contrast to David. ${ }^{117}$ Asahel may be David's servant and even related to him (see 1 Chr. 2:16) but he is not like him. ${ }^{118}$ By taking matters into his own hands, he instead exhibits the same attitude as the one he is pursuing.

\footnotetext{
${ }^{116}$ Further parallels between the deaths of Saul and Asahel include: (1) both die from a belly wound and (2) the groups that bury Saul and Asahel both walk all night (1 Sam 31:12; 2 Sam 2:32). It should also be noted that both Asahel and Saul are associated with the term (2 Sam 1:19;2:18).

${ }^{117}$ It is noteworthy that the only time the verb רדָד is associated with David is in 1 Sam 30 where he pursues the Amalekites who raided and burned Ziklag. Instead of pursuing fellow Israelites like Saul and Asahel, David pursues the enemies of Israel in order to finish the conquest.

${ }^{118}$ The contrast between Asahel and David is further highlighted by the description of Asahel as "swift of foot" in v. 18. The first occurrence of the term "foot" in Samuel is in 1 Sam 2:9 in the song of Hannah where she says that the Lord will guard the feet of the faithful ones but the wicked shall be silent in darkness - for by strength no man shall prevail. The most prominent example in the book of one whose feet are guarded is David who is protected by the Lord and who does not prevail by strength but by trusting in the Lord. Asahel, on the other hand, tries to prevail by strength but does not succeed. Though he is swift of foot, his feet are not guarded.

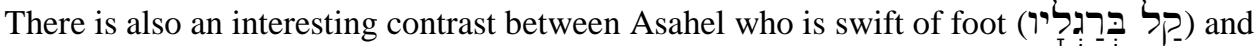

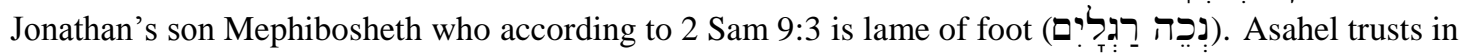
his strength and speed yet in the end he is dead. Though he is a relative of David, he is not a true servant of his. Mephibosheth has no strength he can trust in, he is a cripple. Though he is a relative of Saul, he ends up at David's table and becomes like a son to him.
} 
Verse 19

This is further emphasized by the fact that according to v. 19 Asahel did not turn to the right or to the left from following Abner. Significantly, both the phrase "turn to the right or to the left" as well as the combination strongly associated with following God and being obedient to his law. ${ }^{119}$ The wording of v. 19 thus reminds the attentive reader what the underlying problem in the entire literary unit is, namely a failure to be obedient to God and his law. Instead of following the example of their king and true master David, who obediently followed the Lord in the previous literary unit, both Israel and Asahel "follow" Abner by selfishly taking matters into their own hands without waiting for or inquiring of the Lord, thus willingly causing strife between brothers. Ironically, in the end it is precisely Asahel's similarity to Abner that gets him killed. Abner, on the other hand, appropriately suffers the covenant curse of being pursued because he turned aside from the word of the YHWH that stated that Israel should only make a person chosen by God king over them (Deut 17:15; 28:14, 22, 45).

Verse 20

Abner's reaction to Asahel's pursuit is interesting. Instead of defending himself, he turns around and engages his pursuer in a dialogue. The scene is reminiscent of 2 Samuel 1 where the young Amalekite reports on his encounter with Saul on the battle

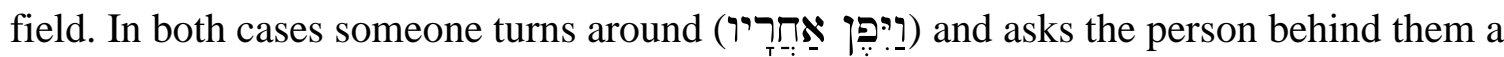

${ }^{119}$ Polzin, David and the Deuteronomist, 30. See e.g. Num 14:43; Deut 5:32; 7:4; 17:11, 20; 28:14; Josh 22:16, 18, 23, 29; 1 Sam 12:20. 
question regarding their identity (2 Sam $1: 7 ; 2: 20) .{ }^{120}$ Yet in contrast to Saul and the Amalekite, Abner and Asahel are not just fellow Israelites, but also seem to know each other as Abner's opening question suggests. ${ }^{121}$ In addition, unlike Saul Abner does not ask the one who is behind him to kill him, but actually seeks to avoid any bloodshed, precisely because he knows Asahel and his brother Joab (2:22). These differences to the scene in 2 Sam 1 once again highlight the fact that this is an encounter between fellow Israelites who should not pursue and much less kill each other.

The scene in vv. 19-23 also reminds of the two situations in 1 Sam 24 and 26

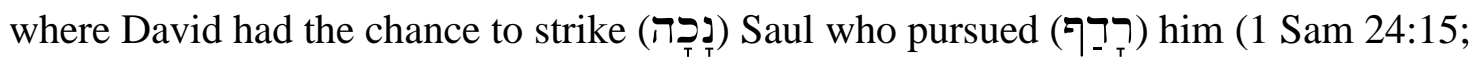
26:8, 18). Here also, the contrast is striking: While David has done nothing to deserve being pursued by Saul, Abner is reaping what he sowed by initiating conflict at the pool of Gibeon. And while both David and Abner confront their pursuers in an effort to change their mind, only David is successful: Twice he and Saul part ways in peace, but Abner ends up killing Asahel. The different outcomes are the direct result of the different attitudes of the respective protagonists. Saul's change of mind is both times caused by the fact that David acted magnanimously towards him and categorically refused to harm him when he had the chance to do so, risking his own life in the process. Abner, on the other hand, selfishly stirred up conflict and is only reluctant about not harming Asahel. In the end, he is forced to kill Asahel to save his own life, when the latter does not turn aside.

\footnotetext{
${ }^{120}$ Further parallels between the two scenes include (1) the mention of a and (2) the appearance of the term נָָּ in connection with the person killed in the encounter (2 Sam 1:10; $2: 23)$.

${ }^{121}$ Morrison, 2 Samuel, 42.
} 
Significantly, Asahel's refusal also presents a contrast to David's attitude, for he does not seek to deescalate the situation like David but instead tries to execute justice himself rather than waiting upon God to do so. ${ }^{122}$ Through these contrasts the author is thus once again able to show that both Abner and Asahel are not like David.

Verse 21

Once Abner has ascertained that it is indeed Asahel who is pursuing him, he twice attempts to convince Asahel to stop his pursuit. First, he encourages him to turn to his right or left and seize one of the young men in order to take his equipment. While Abner's proposal shows that he wants to avoid direct combat with Asahel, it also reveals his inability to resolve the situation peacefully for it simply shifts the conflict away from

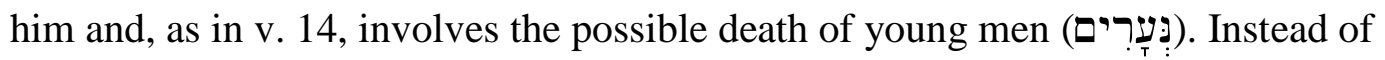
protecting those who belong to his army, Abner thus seems to be quite willing to sacrifice young men for his own purposes. This once again sets him in contrast to David who up to this point has been presented as a leader who cares about those who follow him. ${ }^{123}$ Though David has a young man (פֵֵַַַ) killed in 2 Sam 1, this is not done for personal gain but to execute justice. David's own young men (נְְעִרים), on the other hand, are given

\footnotetext{
${ }^{122}$ The contrast is made evident, among other things, by the term אבד which occurs both in 2 Sam 2 and 1 Sam 26. While Asahel is unwilling to turn aside from pursuing Abner (2 Sam 2:21), David is unwilling to stretch out his hand to kill Saul (1 Sam 26:23).

${ }^{123}$ See e.g. 1 Sam 25:4-13, 30:21-25 and 2 Sam 2:3.
} 
distinctive tasks and receive a blessing in 1 Sam 25 as David refrains from selfishly helping himself with his own hand. ${ }^{124}$

Verse 22

In spite of the fact that Abner's first proposal falls on deaf ears, he once more tries to persuade Asahel to desist. Since Asahel has made it clear that he is not interested in anyone or anything but Abner, Abner now directly tells him to stop pursuing him. He then seeks to reason with Asahel by means of two rhetorical questions. The first (Why should I strike you to the ground?) emphasizes both how confident Abner is of victory and how senseless and unnecessary Asahel's death is. There is no need or good reason for his death. In the end, he dies simply because of his foolish and stubborn refusal to stop his pursuit. This is important because it means that Asahel is responsible for his own death and not Abner. It is also significant, however, in light of the larger narrative. As was already suggested above, through Asahel Abner is confronted with himself. Like Asahel, Abner is in dogged pursuit of something, namely headship over Israel, and will not turn aside instead of single-mindedly following after God, turning neither to the right nor the left. Yet as the narrative clearly shows, Abner's pursuit is foolish for his army suffers a crushing defeat against David's forces and he is forced to kill a fellow Israelite to save his own life. The question he asks Asahel thus also applies to Abner himself. There is no need for his demise, nor any good reason, except his own foolish refusal to back down.

\footnotetext{
${ }^{124}$ See e.g. 1 Sam 25:5 and 2 Sam 1:15. Also note the young Amalekite in 1 Sam 30 who serves as a foil for the young Amalekite in 2 Sam 1. The former is spared by David and given the task of leading David and his men to the Amalekite camp.
} 
Abner's second question (How could I lift up my face to your brother Joab?) serves as yet another reminder that the two men are fellow Israelites who know each other. Abner evidently expects to meet Joab again in the future and is worried about having to face him, a concern that, as it turns out, is warranted. ${ }^{125}$ It does not seem coincidental that precisely at this point the keyword be used to describe the relationship between the two opposing sides. Through the encounter with Asahel Abner is confronted in a personal way with the reality and the consequences of the war between brothers which he initiated. Asahel is not some faceless, nameless opponent, but someone whom Abner knows and who is part of a family. By killing Asahel, he would thus not simply eliminate an opponent but take the life of someone's brother, which in turn would have negative consequences for himself, since he knows that someone personally and since that person would experience great pain and grief at the loss of their brother, causing them to be less than favorably inclined towards Abner. By reflecting on Joab's probable reaction, Abner is thus reminded that killing a brother causes great pain and grief and breeds great hatred toward the killer(s) for the simple reason that brothers are part of the same family and therefore have a special relationship. Significantly, it is precisely this reality that the two sides in the larger narrative seem to have forgotten.

${ }^{125}$ Birch, "First and Second Books of Samuel," 1217. 
Verse 23

Seemingly unmoved by Abner's words, Asahel still refuses to turn aside, causing Abner to finally take action. Yet instead of launching a frontal attack on Asahel, Abner strikes him in the belly with the butt end of his spear. This could be taken as an indication that Abner did not mean to kill Asahel, but only wanted "to knock the wind out of his opponent." ${ }^{126}$ Ironically, the reason Abner's blow is lethal is most likely Asahel's speed. ${ }^{127}$ Thus, the very thing that gave Asahel an advantage over Abner becomes a disadvantage and actually leads to his death. It should also be noted that Asahel's death by means of a spear (חְָנִית) once again sets him in contrast to David who on two occasions escapes Saul's spear (חָנִנית) and later is even able to take that spear away from $\operatorname{him}(1 \operatorname{Sam} 18: 11 ; 19: 10 ; 26: 12)$.

The narrator notes that as a result of Abner's unexpected backward thrust, Asahel "fell there and died on the spot. And all who came to the place, where Asahel had fallen and died, stood still." (v. 23) The repetition of the verb נָפָּ and the occurrence of the

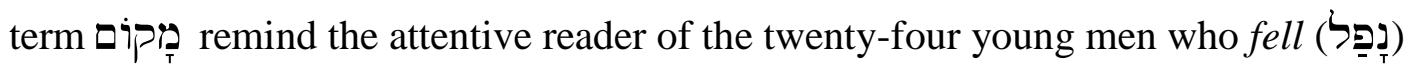
together at the place (פק and pointless and serve as fitting bookends for the battle between fellow Israelites that day, for it is the fall of the twenty-four that precipitates the outbreak of hostilities in v. 17, while the fall of Asahel brings the battle to a halt. The term פִָּ further reminds of

\footnotetext{
${ }^{126}$ Bergen, 1,2 Samuel, 304; Morrison, 2 Samuel, 43; vom Orde, Das zweite Buch Samuel, 49.

${ }^{127}$ Morrison, 2 Samuel, 42-43.
} 
David's lament in 2 Sam 1:19-27 in which he repeats three times that the mighty have fallen (נפכֵל). While this line primarily looks back to Israel's defeat and the deaths of Saul and Jonathan in 1 Sam 31, it also serves as an appropriate commentary on the civil war and Asahel's death in 2 Sam 2. ${ }^{128}$ Thus, the lament provides yet another link between Saul and Asahel, both of whom are fallen mighty men that die from a belly wound.

The report of Asahel's death also sets him in contrast to David once again. Twice the reader is informed in v. 23 that Asahel fell there. Significantly, the term $\underset{\tau}{\underset{T}{*} \text { also }}$ occurs in the previous literary unit. According to v. 4 David who refuses to help himself with his own hand and humbly inquires of the Lord goes up to Hebron and is anointed as

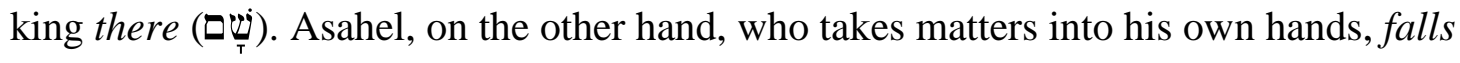
there (שָ $)$ and dies. Through the repetition of the term ț the author thus highlights the different fates of these two men.

Verse 24a

As already noted above, once swift Asahel has been brought to a halt, others slow down and stop as well. It almost appears as if, after a day of action and fighting, the death of Asahel finally causes people to stop and think about what is happening. Yet not everyone stops. In striking contrast to those who stand around Asahel's bloody corpse, Joab and Abishai keep moving as they take up the pursuit of Abner in place of their fallen brother. Though this is not surprising, because they apparently want to finish the job

\footnotetext{
${ }^{128}$ Further support for this conclusion comes from (1) the fact that according to 2 Sam 23:24 Asahel was among David's mighty men and (2) the fact that the term צִ tִ that is used to describe Asahel in 2:18 ("Asahel was swift of foot like one of the gazelles...") also occurs in 1:19 ("The beauty of Israel...").
} 
Asahel started and in the process avenge their slain brother, it is nevertheless also quite troubling, for by positioning the opening line of v. 24 right after the closing statement of v. 23, the author creates the impression that the only people who did not stop at the place where Asahel fell and died were his own brothers. ${ }^{129}$ So obsessed are they with catching Abner that they leave their brother's corpse out in the open, exposed to the elements and animals, even after the sun has set. ${ }^{130}$ Though they later return and bury Asahel, their initial neglect in this matter does not reflect positively on them and stands in stark contrast to the behavior of the men of Jabesh-Gilead who, though they were not even related to Saul and his sons, walk all night in order to protect their bodies from further disgrace and provide them a proper burial as soon as possible. Significantly, Asahel also serves as a foil for the men of Jabesh-Gilead, as noted above. Hence, Joab and Abishai's behavior further confirms what was already suggested by the close parallel between the opening line of v. 24 and the opening line of v. 19, namely that the two brothers are no different than Asahel and that their pursuit of Abner is just as problematic as his.

\section{Verses 24b-28}

Verse $24 b$

While Joab and Abishai are still in hot pursuit of Abner, the sun goes down. Together with the sunrise at the very end of the chapter the sunset mentioned here

\footnotetext{
${ }^{129}$ Fokkelman, Throne and City, 56: ,....they are the only ones who fail to pause at the body of Asahel. The two lines $23 \mathrm{f}$ and $24 \mathrm{a}$ almost clash because of this difference."

${ }^{130}$ Morrison, 2 Samuel, 44: "The thought of a dead body abandoned to the elements cannot be far from the minds of the audience, whether ancient or modern." Though the Bible does not give much information regarding funeral practices, the texts where funerals are mentioned suggest that it was the duty of the deceased's relatives to protect the corpse and ensure that it received a proper burial. See e.g. Gen 23; 25:8-10; 35:29; 50:1-14; 2 Sam 21:10. It also seems that ideally corpses were to be buried before sundown.
} 
provides a frame around scenes four and five. ${ }^{131}$ At the same time, the approaching

darkness is a fitting commentary on the situation at this point of the narrative. Night is falling on the two warring parties, not just literally but also in a figurative sense. This use of the sunset as a commentary on the larger narrative is reminiscent of Gen 28 where the sun sets on Jacob as he is fleeing from his brother Esau after stealing the blessing from him by deception (Gen 28:11). As in 2 Samuel 2, there is a conflict between brothers that has not been resolved and the result is darkness.

Verse 25

The sun sets just as Abner and his pursuers reach the hill of Ammah which is before Giah by the way of the wilderness of Gibeon. ${ }^{132}$ Here the pursuit comes to an end (though not in the way Joab and Abishai intended), for not only is Abner now protected by the cover of darkness, he also is joined by the sons of Benjamin who gather behind him. While Abner thus receives some much-needed support, it is nevertheless striking that only the Benjaminites rally around him, given that Abner is the commander of the forces of Ish-boshet, whom Abner made king over all Israel. Where are all the other tribes? Though their absence is not explained, the impression is given that when it comes down to it, Abner (and with him Ish-boshet) can only count on the support of Benjamin.

\footnotetext{
${ }^{131}$ Fokkelman, Throne and City, 57. The fact that the sun goes down right after Joab and Abishai pursue Abner instead of stopping at the place where Asahel died, but rises again once they have properly buried him, strengthens the impression that their failure to attend to their brother's body immediately is problematic.

${ }^{132}$ The locations of Ammah and Giah as well as the meaning of the two terms are uncertain. If the terms mean "aqueduct" and "spring," respectively, as some have suggested (see, e.g. Fritz Stolz, Das erste und zweite Buch Samuel, ZBK 9 [Zürich: Theologischer Verlag, 1981], 194; vom Orde, Das zweite Buch Samuel, 50; McCarter, II Samuel, 96), this would provide another connection to the parallel scene in vv. $13 \mathrm{~b}-17$ where the two opposing parties meet at a pool.
} 
This is not surprising given the way Ish-boshet was made $\operatorname{king}^{133}$ and considering that Abner is a Benjaminite and that, as v. 14 suggested, the conflict also appears to revolve around the issue of Benjamin's continuing supremacy over the other tribes. Much is at stake, therefore, for Benjamin. That they gather behind Abner is fitting, for like him they seem to be driven by selfish pride and ambition rather than humble obedience to the divine will. By gathering behind Abner, they accept him as their leader and thus also give their support to his rebellion against YHWH.

That the sons of Benjamin gather behind Abner is noteworthy for another reason as well. The last time the exact form 1 Sam 22:2, where all those who were in distress, in debt and discontented gathered around David when he was fleeing from Saul. Thus, both Abner and David have a group of people gather around them while they are fleeing from someone. ${ }^{134}$ The parallels do not end there, however. As scholars have recognized, the scene in 2 Sam 2:25-27, where Abner

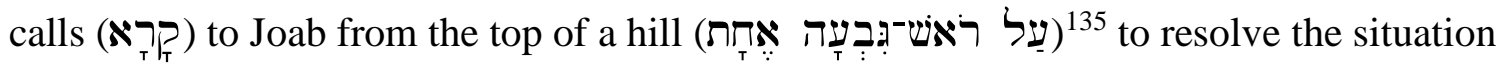

${ }^{133}$ See the discussion above on $2: 8-9$.

${ }^{134}$ Note also the similarity between 2 Sam 2:25 where the sons of Benjamin gather behind Abner

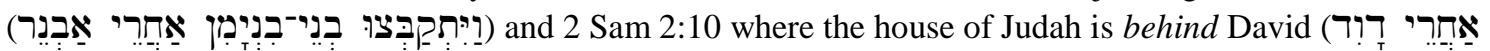

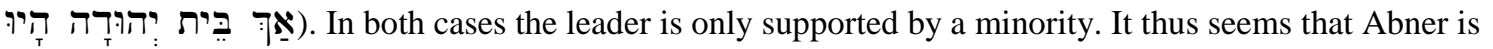
brought into a situation that is similar to the one he caused David to be in. This is yet another subtle hint that the tables are turning. At the same time, however, the parallel further highlights the contrast both between David, who sends a message of blessing to fellow Israelites and safely reigns from Hebron and Abner, who kills a fellow Israelite and has to run for his life as well as between the Judahites, who support the divinely chosen king and the Benjaminites, who support the one who rejects the divine choice and instead has installed his own king.

${ }^{135}$ Literally ,on the top of one hill.” It is interesting that the term $\underset{T}{\mathrm{~T}}$ occurs twice in v. 25, emphasizing that the Benjaminites became one troop and stood on the top of one hill. The unity that is thus emphasized stands in ironic contrast to the disunity of Israel in this situation. The repetition of the term או: is therefore yet another subtle reminder that Israel should not fight against itself but join together in true unity. 


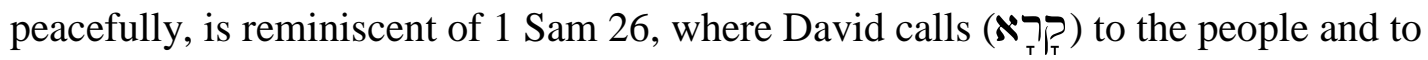

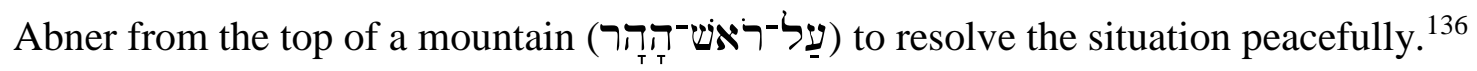
While these similarities at first glance suggest that Abner is like David, closer examination shows that this is not the case. While David never challenges Saul and his kingship (even though he already is anointed and Saul has already been rejected) and is therefore unjustly pursued, Abner is pursued precisely because he has challenged David and his kingship (even though he is not anointed). In contrast to David, Abner therefore cannot complain about being pursued. Furthermore, while David takes away Saul's spear instead of killing him with it (1 Sam 26:12), Abner kills Asahel with his spear (2 Sam 2:23). While David's actions, as well as the way he speaks to Saul, thus reveal his genuine desire for peace, Abner's actions and words suggest that he is only concerned about saving his own skin.

Verse 26

As in v. 14, Abner initiates the dialogue with Joab and as in his communication with Asahel, he resorts to rhetorical questions. The connection to the earlier dialogue at the pool of Gibeon is important, because it reminds the attentive reader that it was Abner who instigated the conflict that day. This makes his words to Joab sound all the more ironic. Abner could just as well pose the same three questions to himself. But instead of doing this and admitting that he is ultimately responsible for the bloodshed that day,

\footnotetext{
${ }^{136}$ Robert P. Gordon, I \& II Samuel: A Commentary (Grand Rapids, MI: Zondervan, 1999), 216; David G. Firth, 1 \& 2 Samuel, ApOTC 8 (Downers Grove, IL: IVP Academic Press, 2009), 339; Fokkelman, Throne and City, 58.
} 
Abner indirectly blames Joab, while at the same time insinuating that Joab would let the killing go on indefinitely (question 1) because he is neither smart enough to realize the long-term consequences of the conflict (question 2) nor considerate enough to stop the people from pursuing their own brothers (question 3). Abner thus employs a manipulative approach, designed to cast him in the role of the victim, while making Joab appear heartless and stupid. This once again says much about Abner's character.

Verse 27

In contrast to his brother Asahel, Joab responds to Abner, though he does not answer any of his questions. Instead, he puts the blame back on Abner. Scholars are divided with regard to the precise meaning of his statement, with the majority favoring the interpretation that Joab is indicating to Abner that the people would have continued to fight until the morning, if Abner had not made his appeal. ${ }^{137}$ As Fokkelman correctly notes, however, this interpretation is only possible if the Hebrew text is changed. ${ }^{138}$ When the text is left as it is, it reads: "As the Lord lives, if you had not spoken, the people would have departed already this morning, each one from following his brother." The meaning of Joab's words becomes clear once the structural connection to the earlier scene at the pool is recognized. Joab is not referring to Abner's appeal on the hill but to

\footnotetext{
${ }^{137}$ See e.g. Bergen, 1,2 Samuel, 304; Anderson, 2 Samuel, 45; vom Orde, Das zweite Buch Samuel, 50; Gordon, I \& II Samuel, 216; Brueggeman, First and Second Samuel, 223; Morrison, 2 Samuel, 44.

${ }^{138}$ Fokkelman, Throne and City, 59: "A serious methodological mistake is made here: because it is initially difficult to determine the lines along which the oath develops, what happens is that the most likely interpretation is chosen first and the Hebrew text is then adapted to it by changing lū $l \bar{e}$ to $l \bar{u}$ (its opposite!) or by taking habboqęr to mean 'the following morning', which is untenable. The correct approach is the other way around: recognize that the Hebrew is utterly sound, translate the sentence without associations and mind-bending ideas, then and only then look for a plausible interpretation."
} 
his initial proposal that morning at the pool. If Abner had not proposed a contest, Joab is suggesting, it would not have been necessary to fight at all. ${ }^{139}$

As Fokkelman further recognizes, the wording of Joab's statement reminds of David's oath to Abigail in 1 Sam 25:34. ${ }^{140}$ Both statements open with an oath formula

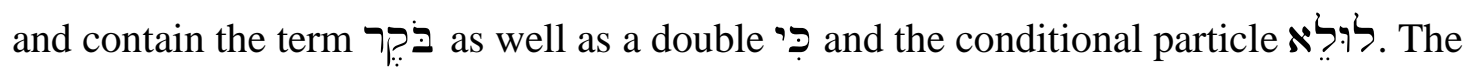
parallels are significant because of the contrast between the two scenes and the two pairs of characters involved. While in both cases the oath marks the end of conflict between fellow Israelites, David's oath occurs before any harm has been done, whereas Joab's oath is taken after a day of fighting and killing. This difference is due to the contrasting attitudes and actions of the other two characters, Abigail and Abner. While Abigail unselfishly risks her life to prevent bloodshed between Israelites and approaches David in a spirit of humility, Abner selfishly initiates and contributes to such bloodshed, first to further his own agenda and then to save his own life. While Abigail is willing to take the blame for her husband's behavior upon herself, Abner blames Joab for a situation that he himself is ultimately responsible for. Abner is not like Abigail and therefore also not like David, since Abigail functions as David's alter ego in 1 Sam $25 .{ }^{141}$ Significantly, Joab is not like David either. While David's oath is a promise that he will not take vengeance

${ }^{139}$ Fokkelman, Throne and City, 59-60.

${ }^{140}$ Fokkelman, Throne and City, 60 . Both statements open with an oath formula and contain the

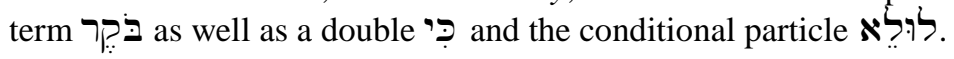

${ }^{141}$ Leithart, A Son to Me, 140, calls her ,a female David.” Both David and Abigail are associated

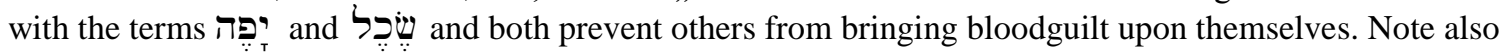
the similarities between the way David addresses Saul in 1 Sam 24 and the way Abigail addresses David in

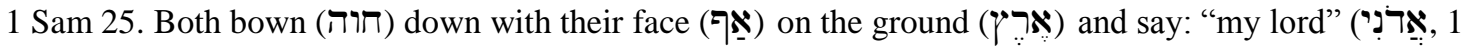
Sam 24:9; 25:23-31, 41). 
upon Nabal and his house, Joab makes no such promise to Abner. ${ }^{142}$ Instead of refraining from further action like David and trusting God to take vengeance, Joab only refrains for a while, but then takes matters into his own hands again in 2 Sam 3, thus exhibiting the same attitude as Abner and Asahel. ${ }^{143}$

Verse 28

Somewhat surprisingly, Joab indeed calls off the pursuit in v. 28 by blowing the trumpet, finally causing all the people to come to a halt. Interestingly, this is the first time in the Old Testament that a trumpet is blown to bring fighting to an end as well as the first time a trumpet occurs in the context of a conflict between Israelites. Each time a trumpet is blown previously, it is used either to call Israelites together to fight against enemy armies as in Judg 3 and 1 Sam 13 or to signal the beginning of an attack on those armies as in Josh 6 and Judg 7. The blowing of the trumpet in 2 Sam 2:28 thus seems to be another reminder of what Israel's actual task is. Instead of fighting against each other the people should be joining together to fight against their enemies and finish the conquest as David has been doing.

\footnotetext{
${ }^{142}$ Note also that, unlike David, Joab does not employ the covenant name YHWH but uses the more general איה instead.

${ }^{143}$ Yet Joab is smarter than Asahel. In contrast to Asahel, who does not talk to Abner and refuses to turn aside, Joab responds to Abner's appeal and gives up the pursuit - at least for a while. Joab wants to kill Abner as much as Asahel does, yet, unlike his younger brother, he is able to assess the situation realistically and to wait for a more opportune time.
} 


\section{Verses 29-32}

Verses 29-30a

The final section of this literary unit describes the retreat of the two armies back to their respective home bases, thus bringing the story full circle. The section has been arranged in such a way that the retreat of the two sides is split up and placed around a report of the number of casualties on each side. ${ }^{144}$ This arrangement once again invites the reader to compare the two sides. A number of similarities as well as differences may be noted. ${ }^{145}$

First, both Abner and Joab withdraw together with their men. This is interesting, since at the beginning of the narrative they went out with the servants of Ish-boshet

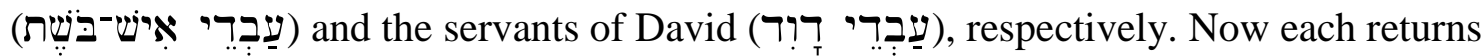

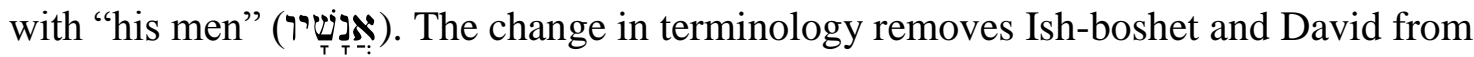
the picture and places the focus completely on Abner and Joab, thus reinforcing the impression that the whole conflict has turned into a personal feud between the two generals and those who support them. Instead of commanding the servants of their kings, they are now leading their own armies. While the wording thus again highlights the similarity between Abner and Joab, it also once more sets both of them in contrast to David, the only individual in the Old Testament previously associated with the form

\footnotetext{
${ }^{144}$ Fokkelman, Throne and City, 61.

${ }^{145}$ Fokkelman, Throne and City, 61-62: "Joab's pulling out with his army in 32cd is clearly both parallel and opposite to that of the Benjaminites."
} 


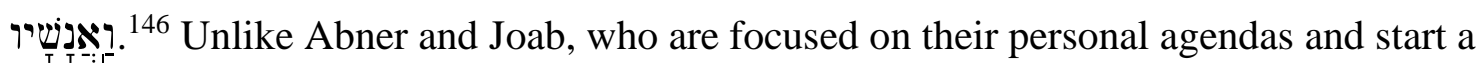
civil war in Israel, David and his men do not go into battle against their fellow Israelites (1 Sam 29:2, 11), but instead faithfully serve their king and their countrymen by fighting against Israel's enemies (1 Sam 18:27; 23). The contrast thus further strengthens the impression that Abner and Joab are not like David, while at the same time once again reminding the reader what Israel's actual task should have been.

A second similarity between the two sides in 2 Sam 2:29-32 is that both walk all night. As mentioned above, this detail reminds of the men of Jabesh-Gilead who walk all night to retrieve and bury the bodies of Saul and his sons (1 Sam 31:11-13). The contrast between the scenes does not reflect positively on the two groups in 2 Sam 2 . While the men of Jabesh-Gilead walk all night in order to show חסיר to their lord Saul, Abner and his men and Joab and his men walk all night after a day on which they have shown anything but to each other. The men of Jabesh-Gilead walk all night into enemy territory to retrieve the bodies as quickly as possible. The two sides in 2 Sam 2 walk all night to get home as quickly as possible.

Besides the two similarities just mentioned, there are also a number of differences between the retreats of both sides, however. While Abner and his men have to walk through the עִ עִרבָָ and cross the Jordan to get to Mahanaim, this is not necessary for Joab and his men, who are headed for Hebron. The עִרָָ usually translated "plain" or "desert," designates "a depression extending south from the Sea of Galilee to the Gulf of

\footnotetext{
${ }^{146}$ Prior to 2 Sam 2:29 וַאיָנָשָׁיו exclusively refers to the men of David.
} 
Aquabah, embracing the Ghor or Jordan Valley north of the Dead Sea."147 Prior to 2 Sam 2 , it is used almost exclusively in the context of the conquest and the division of the land. ${ }^{148}$ Most of the references specifically designate the plains of Moab where the Israelites camped just before crossing the Jordan to begin the conquest. ${ }^{149}$ This is interesting because Abner and his men are also in the עִ עִרבָ prior to crossing the Jordan. In contrast to Israel, however, they have not been fighting Israel's enemies but other Israelites and are crossing the Jordan in the opposite direction, thus leaving the land. That they return to Mahanaim is fitting, for by refusing to accept David as the divinely chosen king of Israel and initiating a civil war instead, Abner and his men have kept Israel divided into two camps.

Joab and his men, on the other hand, return to Hebron, a location that, as

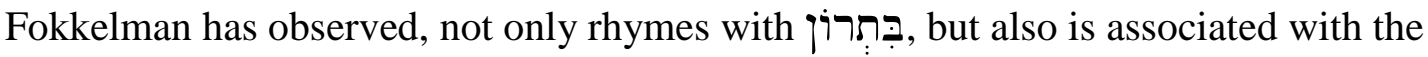
exact opposite of division, namely unity. ${ }^{150}$ Significantly, it is at this point that it becomes light again. That the dawning of a new day is specifically associated with Hebron, but not with Mahanaim, once again appears to emphasize the superiority of the former over the latter. Hebron, not Mahanaim, is the place of light, since it is the divinely chosen city and the residence of the divinely chosen king. The sun went down back in v. 24 after a day of fighting and disunity between fellow Israelites, caused by the refusal of some to accept

\footnotetext{
${ }^{147}$ McCarter, II Samuel, 97.

${ }^{148}$ Only two of the 34 prior occurrences are not tied to the conquest and the division of the land.

${ }^{149}$ E.g. Num $22: 1 ; 26: 3,63 ; 31: 12 ; 33: 48-50 ; 35: 1 ; 36: 13$.

${ }^{150}$ Fokkelman, Throne and City, 61-62.
} 
this king. As the experience of Abner and his men, who seem to arrive at Mahanaim while it is still night, suggests, those who persist in this attitude will remain in darkness and keep Israel divided into two camps. ${ }^{151}$ A new day for them, as well as for all Israel, will only dawn as they follow the example of Joab and his men and go to Hebron to accept David as their king. Only then will Israel be truly united once more.

Verses 30b-31

Sandwiched in between the description of the withdrawals of the two sides is a report about the losses on each side. Again, the contrast is striking: nineteen men of the servants of David are missing and Asahel is dead as opposed to 360 men of Benjamin and of Abner's men which have been struck down by the servants of David. The way the losses are reported further highlights the contrast. While it is clearly stated that the 360 men of Benjamin and of Abner's men are dead (מוּת), the nineteen men of the servants of David are said to be missing (niphal of בָָָרד). In addition, while the losses on Abner's side are due to an active "striking" (נָכָז) of the servants of David, no such activity is reported of the men of Abner in v. 30. As a result, the servants of David are mentioned twice in this section, while Abner's forces are only mentioned once. Hence both the content as well as the form of the report in vv. 30 and 31 emphasize the superiority of the servants of David over the forces of Abner.

\footnotetext{
${ }^{151}$ Fokkelman, Throne and City, 62: "In the 'historical' reality which lies behind the narrated world the sun rises and sets over everyone; but not in the narrated world, here the narrator has the unprecedented option of mentioning things or omitting them. The sunset of v. 24 holds good for both armies it is true, but it has a link with 32 which grants the sunrise to Judah only. This piece of information is retroactive in its effect, to the detriment of Abner. He and his army no longer emerge from the darkness, Joab and his army do."
} 
Verse 32

In v. 32 Asahel is finally laid to rest in his father's grave in Bethlehem. Since Asahel is also mentioned at the end of v. 30, his name ("God has done") provides a frame around v. 31, further supporting what already seemed to be hinted at in v. 17, namely, that the victory of the servants of David was ultimately an act of YHWH. That Asahel is

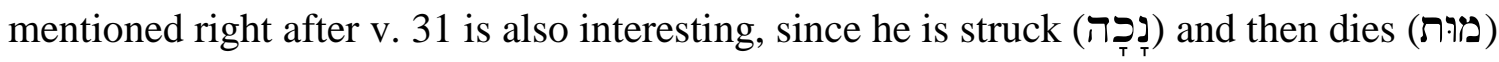
just like those of Benjamin and of the men of Abner. ${ }^{152}$ Through the shared terminology Asahel is therefore once again associated with the side of Abner.

Like the following two chapters, 2 Sam 2 thus closes with a funeral, which in this case takes place in the dark of night. It is the fitting end to a literary unit in which what God has done has indeed been killed and buried and night has fallen upon Israel. Yet death and darkness do not have the final word as a new day of life dawns at Hebron, the divinely chosen residence of the divinely chosen king.

\section{Implications for the Nature of David's Kingship}

Though David does not make an appearance in this literary unit, the passage nevertheless provides further insights into the nature of his kingship, in particular through the contrast between the events and the main characters in this narrative and those in the previous unit. Besides a number of new aspects that are introduced in this narrative, many of the aspects of David's kingship already highlighted in the previous literary unit are

\footnotetext{
${ }^{152}$ Fokkelman, Throne and City, 63.
} 
confirmed and expanded upon. At the same time this literary unit forcefully illustrates what happens when the foundational principles of David's kingship are abandoned.

\section{The Legitimacy of David's Kingship}

Chosen by God. David's divine election seems to be indirectly hinted at in the report of the encounter at the pool of Gibeon. While the twelve contestants from Abner's forces fight "for Benjamin" and "for Ish-boshet, the son of Saul," the twelve representatives from Joab's army are simply "from the servants of David." Whereas Abner's side thus seems to view the contest as a way to assert the continuing supremacy of Benjamin and the house of Saul and to legitimize Ish-boshet's kingship, David's kingship appears to need no such legitimation. In fact, such legitimation would stand in complete contradiction to the way he became king after being divinely elected.

A true son of Abraham. As suggested above, the contest at the pool of Gibeon appears to revolve around the question who the true sons of Abraham are. Though from a human perspective Ishmael is the true son of Abraham, since he is fathered by Abraham, the Genesis account makes it clear that Isaac is the true son of Abraham, for he is the son of the promise who is not begotten through human effort but through divine intervention. In the same way, while Ish-boshet appears to be the legitimate heir of Saul, since he is his biological son, it is actually David who is Saul's legitimate successor, since he is chosen by God. Thus, David is the true son of Abraham, as is also shown by the fact that, like both Abraham and Isaac, he waits patiently and obediently for God to fulfill his promises instead of taking matters into his own hands. This makes the contest at the pool unnecessary. 
Qualified by his character. The literary unit provides further insights into the character of Abner. Rather than accepting David as the divinely chosen king of Israel, he selfishly stirs up conflict in order to seize the kingship for Ish-boshet. When he is pursued by Asahel, he tells him to go after one of the young men in order to save his own skin. Though he does not want to kill Asahel, in the end he is forced to do so and thus causes even more hatred and bitterness. Instead of acknowledging his responsibility in initiating the conflict, however, Abner indirectly blames Joab for the bloodshed and casts him in a negative light, while making himself appear as a victim.

Though they are his opponents, the sons of Zeruiah are very similar to Abner, as is already subtly hinted at by the fact that they follow after Abner. All three brothers do not seek to deescalate the situation but rather help to initiate and prolong the conflict. Joab agrees to the contest at the pool that Abner proposes and all three brothers pursue Abner in an effort to execute justice themselves. Only after Abner takes the initiative to end the conflict does Joab call off the pursuit. Like David in a similar situation, Joab makes an oath, yet in contrast to David, he does not promise that he will not take vengeance upon Abner, suggesting that he is only waiting for a more opportune time to avenge his brother. That this is indeed the case is confirmed in 2 Sam 3.

Both Abner and the sons of Zeruiah thus follow the example of Saul and like him serve as foils for David, who consistently refuses to stir up conflict in Israel in order to seize the kingship, but seeks to prevent unnecessary bloodshed and waits patiently for the kingdom to be given to him. While the attitude of Abner and the sons of Zeruiah leads Israel into civil war, the attitude of David leads to peace and unity. 


\section{Foundational elements of David's Kingship}

Protection of and Kindness toward Followers. The difference in character between David on the one hand and Joab and Abner on the other has a direct effect on the well-being of their followers. Whereas David is consistently portrayed as a leader who protects and cares about those who follow him and shows kindness to them, both Abner and Joab are willing to risk the lives of young men from their armies for their own purposes or, as in the case of Abner, to sacrifice young men in order to save their own skin. While David's young men share in the royal blessing David receives from Abigail when he refrains from helping himself with his own hand and dwell with him in safety in the cities of Hebron, the young men of Abner and Joab lose their life because of the selfish ambition of their leaders.

Wisdom. As shown above, both Asahel and Abner are involved in pursuits in this literary unit, with Asahel's pursuit of Abner mirroring Abner's pursuit of kingship over all Israel. Both pursuits are presented as foolish, since they lead to strife and bitterness between brothers and ultimately death. In contrast to the foolishness exhibited by Asahel and Abner stands the wisdom of David which he demonstrates in his dealings with Saul, in his refusal to take matters into his own hands to secure kingship (i.e. pursue kingship), as well as in his message of blessing to those who buried Saul. David's wisdom is characterized by a humble trust in God which prevents him from acting rashly and seeking solutions that would only benefit him in the short-term.

Divine Guidance. Though God is mentioned once in the literary unit, it is striking that neither party seems interested in receiving divine counsel. No inquiry of the Lord is reported before the two armies head out at the beginning of the narrative, before the 
contest of the pool or before Asahel and later his two brothers pursue Abner. This apparent lack of concern for divine guidance and the disastrous consequences that result from it contrast sharply with David's practice and experience in previous chapters, including his inquiry of the Lord and subsequent move to Hebron at the beginning of 2 Sam 2, and reaffirm the central importance of divine guidance and counsel for the success of David's kingship.

Obedience to God and his law. As suggested above, the wording in vv. 19 and 21 seems to be a subtle reminder that the central problem in the narrative is a failure to follow after God and his law without turning to the right or the left. This is also suggested by the fact that the 24 contestants, who represent the two opposing parties, are twice designated by the term רֵעי . According to the law, an Israelite was to love his neighbor as himself (Lev 19:18). Instead of loving each other, however, the neighbors in 2 Sam 2:1232 kill each other. In doing so, they follow the example of Saul, whose kingship is taken away and given to his neighbor (רֵּי) David, who is obedient to the law. He does not kill his neighbor Saul, though he has the opportunity to do so, gives gifts to his neighbors in Judah (1 Sam 30:26) and in his first recorded act as king sends a message of blessing to his countrymen who risked their lives to bury the one who sought to kill David.

Unity. The narrative in 2 Sam 2:12-32 is characterized by disunity, not only between the two opposing parties of Israelites but significantly also within Abner's forces, for by the end of the narrative it appears that only the tribe of Benjamin is still supporting him. This does not bode well for Ish-boshet's kingship. The light associated with Hebron at the end of the literary unit suggests that Israel's hope lies in seeking unity and directs the reader's attention back to David who reigns from Hebron and through his 
message to the men of Jabesh-Gilead in the previous literary unit demonstrated not only that the unity of Israel is an important element of his kingship but also how this unity may be achieved.

$70 గ \because$ and repaying good with good. In contrast to the previous literary unit, the term concept in the events reported in the narrative. Instead of showing דֶֶ and repaying good with good like David and the men of Jabesh-Gilead, the characters in 2 Sam 2:1232 fight against each other and repay evil with evil. The result is bitterness, pain and death. These negative consequences reaffirm the importance of if it is to be successful.

\section{The Purpose of David's Kingship}

Salvation for Israel. The literary unit forcefully shows that grasping for kingship leads to hatred, bitterness and division between brothers, as well as to darkness and death, all of which are associated with sin. The selfishness and personal ambition that lies at the root of such grasping and which is demonstrated by all the main characters in 2 Sam 2:12-32 stands in marked contrast to the selflessness and humility exhibited by David both on his way to the throne as well as in his first royal act described in the previous literary unit. As the previous chapters in $1-2$ Samuel show, David's attitude prevents him and others from sinning.

Finish the conquest. The literary unit is dominated by the civil war between fellow Israelites. Through a number of allusions to passages in Numbers, Joshua, Judges and 1 Samuel, the reader is once again reminded that (1) instead of fighting against each 
other, Israel should focus on fighting against Israel's enemies in order to finish the conquest and that (2) this has been the consistent concern of David both before and after his ascent to the throne. 
CHAPTER 3

EXEGESIS OF 2 SAMUEL 3

2 Samuel 3:1-5

Text

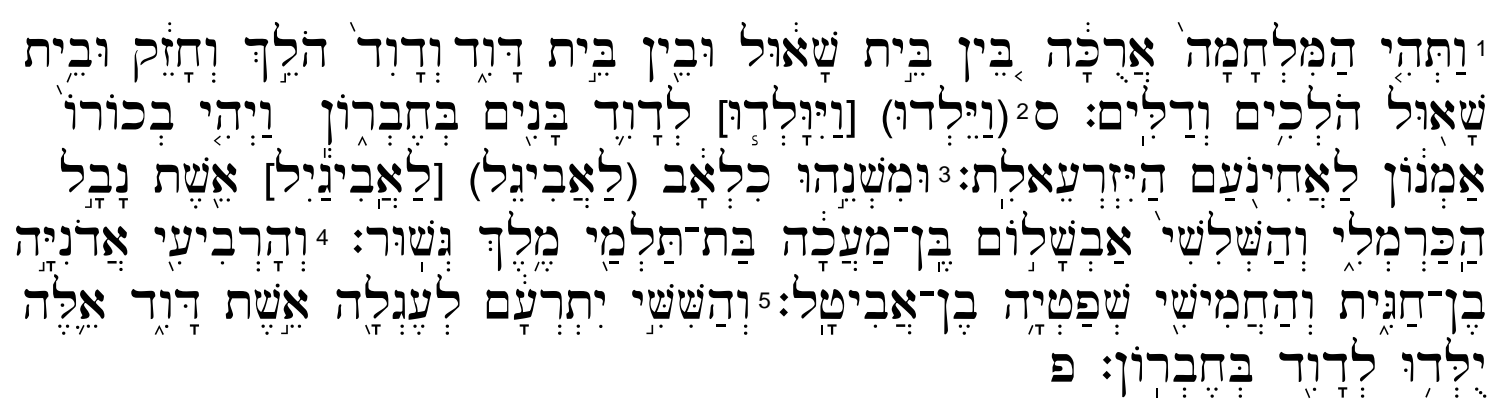

Translation

${ }^{1}$ Now the war between the house of Saul and the house of David was long. While David grew stronger and stronger, the house of Saul grew weaker and weaker.

${ }^{2}$ And sons were born to David in Hebron. His firstborn was Amnon, of Ahinoam of Jezreel ${ }^{3}$ and his second Chileab, of Abigail the wife of Nabal the Carmelite, and the third Absalom the son of Maacah, the daughter of Talmai, king of Geshur, ${ }^{4}$ and the fourth Adonijah, the son of Haggith, and the fifth Shephatiah, the son of Abital, ${ }^{5}$ and the sixth Jithream, of Eglah, the wife of David. These were born to David in Hebron.

\section{Delimitation}

As already noted in the previous chapter of this study, the opening verse of 2 Sam 3 seems to function as a transitional statement connecting the narratives in chapters 2 and 3. As such it could be viewed as standing by itself. If it is to be connected with either the preceding or the following pericope, it seems better to group it with the birth report of 
David's sons in 3:2-5, as the majority of scholars do. ${ }^{1}$ Though $3: 1$ certainly has both terminological as well as thematic connections to $2: 12-32$, the structural analysis of $2: 12$ 32 conducted above suggests that v. 32 is the endpoint of that particular literary unit. In addition, while the narrative in 2:12-32 describes a particular point in time, i.e. the battle at Gibeon, both 3:1 as well as 3:2-5 focus on a period of time, i.e. the war between the house of David and the house of Saul and the birth of David's sons that presumably took place during that war. Furthermore, the birth report in 3:2-5 is connected to $3: 1$ in that it further defines the house of David and illustrates how David became stronger and stronger. ${ }^{2}$ Thus, 3:1 seems to be more closely connected to $3: 2-5$ than to $2: 12-32$ and is therefore treated together with the birth report in the present study.

Like v. 1, v. 6 functions as a transitional statement and together the two verses form an inclusio around the birth report in vv. $2-5 .{ }^{3}$ Because of this, v. 6 is included in the structural analysis of the literary unit below. Yet while there are obvious parallels between v. 1 and v. 6, it seems preferable to follow the lead of most commentators and view v. 6 as the introduction to the following narrative rather than the conclusion of the

\footnotetext{
${ }^{1}$ See e.g. McCarter, II Samuel, 100; Evans, 1 \& 2 Samuel, 147; Brueggeman, First and Second Samuel, 224; Arnold, 1 \& 2 Samuel, 436; Birch, "First and Second Books of Samuel," 1218; Tony W. Cartledge, 1 \& 2 Samuel, SHBC 7 (Macon, GA: Smyth \& Helwys Publishing, 2001), 383; Henry P. Smith, A Critical and Exegetical Commentary on the Books of Samuel, ICC 7 (Edinburgh, Scotland: T \& T Clark, 1898), 357.

${ }^{2}$ Smith, A Critical and Exegetical Commentary, 357; vom Orde, Das zweite Buch Samuel, 52; Anderson, 2 Samuel, 50.

${ }^{3}$ Youngblood, “1 \& 2 Samuel,” 828; Cartledge, 1 \& 2 Samuel, 386.
} 
birth report. ${ }^{4}$ The main reason for this is the reappearance of Abner in this verse, who is not mentioned in vv. 1-5 but plays a significant role in the subsequent narrative.

For these reasons the first literary unit in 2 Sam 3 is viewed as comprising vv. 1-5.

\section{Structure}

As mentioned above, vv. 1 and 6 of 2 Sam 3 provide a frame around the birth report in vv. 2-5. Both statements are transitional in nature and refer to the war between the house of Saul and the house of David. The birth report itself consists of a list of six sons of David and their respective mothers that is framed by an introductory and a closing statement indicating that these sons were born to David at Hebron. The structure of the literary unit can thus be diagrammed as follows:

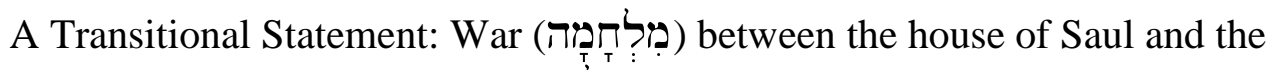

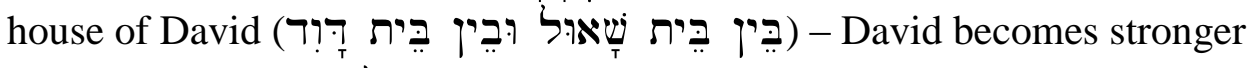

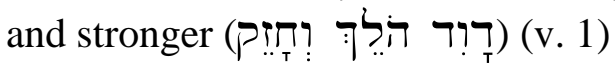

B Sons born to David in Hebron (v. 2a)

X Six sons of David and their mothers (vv. 2b-5a)

B' These were born to David in Hebron (v. 5b)

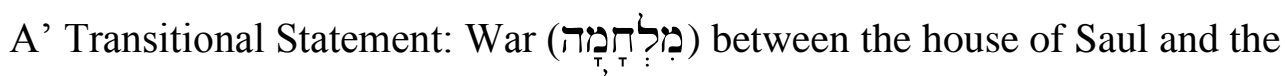

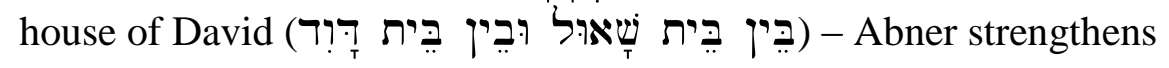

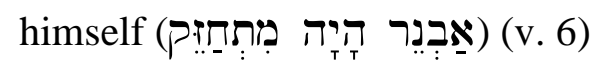

${ }^{4}$ See e.g. Anderson, 2 Samuel, 51; Smith, A Critical and Exegetical Commentary, 358; Campbell, 2 Samuel, 41; Birch, "First and Second Books of Samuel," 1219; McCarter, II Samuel, 103; Arnold, 1 \& 2 Samuel, 437; Stolz, Das erste und zweite Buch Samuel, 197; Firth, 1 \& 2 Samuel, 343; Kevin Mellish, 1 \& 2 Samuel: A Commentary in the Wesleyan Tradition, NBB (Kansas City, MO.: Beacon Hill Press, 2012), 114. 
The arrangement highlights a number of things that are relevant with regard to the nature of David's kingship:

1. David's fruitfulness. The placement of the list of David's sons at the center of the literary unit highlights David's fruitfulness. ${ }^{5}$ The emphasis on life in these central verses contrasts starkly with the bloodshed and death that characterized the previous literary unit, including the encounter between Asahel and Abner in the central scene of that unit, and thus once again distances David from those individuals and events. It also provides yet another contrast between the kingship of David and that of Ishboshet, since no wives or offspring of Ish-boshet are mentioned. Instead, the verses immediately following the list of David's sons suggest that Ish-boshet is unable even to claim the concubine of his father. ${ }^{6}$ He is thus associated with impotence and death.

\section{The strength and continuity of David's kingship. The central placement of} the list of David's sons also emphasizes the growing strength of David's house already mentioned in 3:1. In contrast to the apparently childless Ish-boshet, David fathers not just one, but six sons who are potential successors to the throne. Hence, the prospects that David's kingship will continue are good, while the lack of a successor on Ish-boshet's side suggests that his kingship will come to an end. ${ }^{7}$ At the same time, however, the mention of six sons from six different women as well as the placement of the list right

${ }^{5}$ The theme of fruitfulness is further underscored by the names Jezreel ("God plants"), Carmel ("plantation"), Talmai ("my furrow" or "plowman") and Abital ("my father is dew").

${ }^{6}$ Cartledge, 1 \& 2 Samuel, 384: "Ishbaal inherited a harem from his father Saul, but was unable to claim it though it was his by right. When he accuses Abner of sleeping with Rizpah, she is still 'my father's concubine,' not his own (3:7)."

${ }^{7}$ Firth, 1 \& 2 Samuel, 342. 
after the statement in v. 1 about a long war of succession is "a potent foreshadowing of the danger of another long war of succession following David's reign." 8

\section{Hebron as a place of life. The repeated mention of Hebron as the}

location where David's sons were born affirms what was already hinted at in the final verse of the previous literary unit, namely that Hebron, the city from which David rules, is a place of life. This further supports the impression that David's kingship is associated with life. ${ }^{9}$

\section{The contrast and similarity between David and Abner. The outer elements}

of the structure (A and A') once again invite the reader to compare David and Abner as both are associated with terms deriving from the root $\underset{\mathrm{P}_{\mathrm{T}}}{\mathrm{T}}$ (vv. 1 and 6). ${ }^{10}$ While David

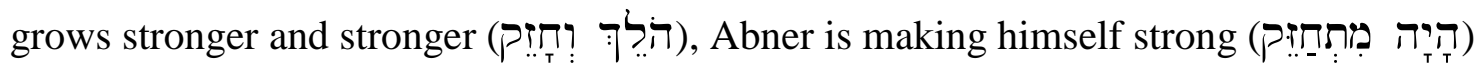
in the house of Saul, thus continuing the self-serving course he pursued in the previous chapter. ${ }^{11}$ The telling absence of Ish-boshet's name in v. 6 - in the position that structurally parallels David's name in v. 1 - not only underscores his weakness and insignificance in comparison to David but also suggests once again that Abner is strengthening himself at Ish-boshet's expense and is in fact the real ruler of the Saulide

${ }^{8}$ Leithart, A Son to $\mathrm{Me}, 188$.

${ }^{9}$ Ironically, however, at least three of the sons listed are later associated with death instead of life. The reason for this is because they repeat the mistakes made by the brothers in 2 Sam 2:12-32: they depart from following after the Lord, fight against each other and seek to gain the kingship by grasping for it.

${ }^{10}$ Robert Alter, The David Story: A Translation with Commentary of 1 and 2 Samuel (New York: W.W. Norton \& Company, 1999), 209; Mellish, 1 \& 2 Samuel, 113; Youngblood, "1 \& 2 Samuel," 833; Graeme A. Auld, I \& II Samuel, OTL (Louisville, KY: Westminster John Knox Press, 2011), 377.

${ }^{11}$ Cartledge, $1 \& 2$ Samuel, 386: "The form of the compound verb (hyh [verb of being] + the causative/reflexive participle of hzq ['to be strong']) indicates that Abner was continuing an action he had begun in the past: he was making himself stronger." 
kingdom. ${ }^{12}$ This is further emphasized by Ish-boshet's accusation in 3:7 that Abner had slept with Saul's concubine, since "sexual relations with a king's wife or concubine in the ancient world was tantamount to a claim to that king's throne."13 All of this reflects negatively on Ish-boshet's kingship and reinforces the impression already gained in the previous literary units that Abner is driven by selfish ambition and seeks to gain power by helping himself with his own hand and through inappropriate means, if need be.

This is precisely what David has consistently refused to do up to this point in the narrative. Instead, he strengthened himself (hitpael of $\underset{-T}{i}$ as in 3:6!) in YHWH (1 Sam 30:6) and sought his counsel before returning to Judah and going up to Hebron. Instead of making himself king, he was anointed as king by the men of Judah. Instead of seeking to extend his power over all Israel by force, David sent a word of blessing to the men of Jabesh-Gilead and only indirectly invited them to accept him as their king. Instead of battling against Abner and his forces for the supremacy over Israel at Gibeon, David is conspicuously absent from that narrative. And in contrast to Abner who is accused of seeking to consolidate his power by sleeping with Saul's concubine, David's strength is illustrated by the sons which his wives bore him. ${ }^{14}$

At the same time, however, David's increasing strength must also be viewed critically. Instead of one wife he has six, thus departing from the divine ideal set forth in

\footnotetext{
${ }^{12}$ Arnold, 1 \& 2 Samuel, 437.

${ }^{13}$ Arnold, $1 \& 2$ Samuel, 437. See also Matitiahu Tsevat, "Marriage and Monarchial Legitimacy in Ugarit and Israel," Journal of Semitic Studies 3 (1958): 237-43; Jon D. Levenson and Baruch Halpern, "The Political Import of David's Marriages," Journal of Biblical Literature 99 (1980): 508; as well as 2 Sam 16:20-22 and 1 Kgs 2:13-25.
}

${ }^{14}$ Note once again the contrast between David's fruitfulness and Abner's lack thereof. 
Gen 2 for humankind in general as well as in Deut 17 for Israel's king in particular. ${ }^{15}$ In addition, there is general agreement among commentators that at least the marriage to Absalom's mother Maacah - who belonged to a people that Israel failed to drive out back at the time of the conquest (Josh 13:13), but whom David had fought against back in 1 Sam 27:8! - was probably politically motivated, since Geshur was located just north of Mahanaim and an alliance would have enabled David to put additional pressure on Ishboshet. ${ }^{16}$ Thus David also strengthened himself in a less than ideal way, providing a parallel to Abner that is interesting in light of the way the relationship between these two characters develops in the immediately following literary unit. As in the case of Abner, David's strength as well as the apparent continuity of his kingship suggested by the birth list are deceptive, for as the remainder of Samuel as well as the beginning of 1 Kings will show, three of the sons mentioned in the list will create strife and disunity in the family and as a result die an unnatural death (two of them before David!) and none of the six will succeed their father on the throne. Firth therefore correctly concludes:

Within this list are the seeds of conflict that will nearly tear David's kingdom apart when David turns from what Yahweh requires. The kingdom thus remains something not to be grasped, but to be accepted from Yahweh, even if the timing of its arrival is complex. The house of Saul cannot grasp that which no longer belongs to it, and in this list which points to David's own strength is a reminder that even he, as the chosen and anointed one, cannot do so either. ${ }^{17}$

${ }^{15}$ Vannoy, 1-2 Samuel, 280 Bergen, 1,2 Saтиеl, 305.

${ }^{16}$ See e.g. Bergen, 1,2 Samuel, 306; Cartledge, 1 \& 2 Samuel, 385; Alter, The David Story, 208; Anderson, 2 Samuel, 49; Firth, 1 \& 2 Samuel, 341; Smith, A Critical and Exegetical Commentary, 357, Vannoy, 1-2 Samuel, 280; Stolz, Das erste und zweite Buch Samuel, 197. Note that this marriage is especially highlighted by being mentioned at the very center of the chiastically arranged literary unit.

${ }^{17}$ Firth, 1 \& 2 Samuel, 342-43. 


\section{Close Reading}

\section{Verse 1}

From the bloodstained battlefield of death at Gibeon and the funeral of Asahel at the close of 2 Sam 2, the narrative shifts to an announcement of new life: sons are born to David at Hebron. Thus, the promise of a new day hinted at in the last verse of the previous literary unit is indeed fulfilled. The scene change is elegantly accomplished by way of a transitional statement in the opening verse of 2 Sam 3 that provides a summary of the war between the house of David and the house of Saul and shows that the truce of Gibeon was only temporary. Hostilities continued, resulting in a drawn-out civil war. ${ }^{18}$

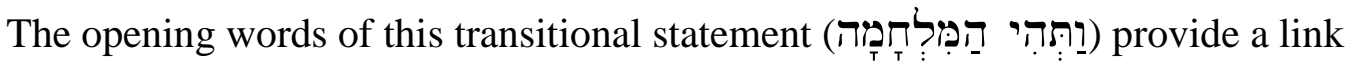
back to 2 Sam 2:17 which begins with the same phrase. ${ }^{19}$ Together the two verses function as a frame around the battle of Gibeon, contrasting the success of David and his servants with the defeat and failure of Abner and the house of Saul and highlighting the

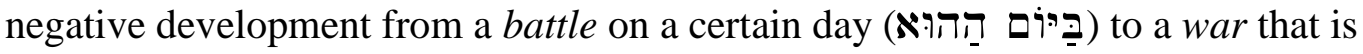
characterized as long (ארז

${ }^{18}$ Alter, The David Story, 208.

${ }^{19}$ Interestingly, both 2:17 and 3:1 are followed by a list of sons. While the birth list in 3:2-5 mentions six sons of David, only three of them reappear later in the book, paralleling the three sons of Zeruiah in 2:18. Significantly, Amnon, Absalom and Adonijah will prove to be quite similar to Joab, Abishai and Asahel, exhibiting the same selfish desire to take things into their own hands without any regard for the brother or the law of God. Thus the parallel arrangement of these sections already provides a subtle hint with regard to the character of these sons of David, as well as to their eventual fate, for like Asahel, all three will die a premature and violent death.

${ }^{20}$ Given that 2:17 seems to hint at the fact that the ultimate source of the success of David's servants against Abner and his men was YHWH (see above), the parallels between 2:17 and 3:1 (and their immediate contexts) may be a subtle indication that the increasing strength of David and the weakening of the house of Saul describe in 3:1 were also ultimately brought about by YHWH. 
Samuel, its appearance at this point of the narrative is interesting in light of the allusions to texts in the Pentateuch about not turning to the left or the right from following after the Lord in the previous literary unit (2 Sam 2:19, 21). In both Deut 5:32-33 and 17:20 the reason given for following after the Lord wholeheartedly is so that Israel may prolong (hiphil of אָרָך) their days in the land which they shall possess and its king may prolong (hiphil of אָרבּ ) his days and those of his sons in his kingship. In an ironic twist, Israel has now turned aside from following after the Lord and "gains" a long war. In addition, as already mentioned above, the birth list that follows 2 Sam 3:1 presents evidence of David's own departure from the divine ideal. By marrying multiple wives, David turned aside from the divine instructions given in Deut 17:17. This resulted in a long period of strife between brothers in his own family which led to his son Absalom having to leave the land and ultimately climaxed in another civil war that caused David to leave the land and to fear for his kingship. ${ }^{21}$ As noted above, in the end none of the six sons mentioned in the birth list succeed David on the throne of Israel.

Yet in 3:1 all of this is still in the distant future. The struggle at hand is not within the house of David but between the house of David and the house of Saul. Significantly, the perfect symmetry which characterizes the first half of the verse is broken precisely at the point where the contrasting fates are described.$^{22}$ Surprisingly, the contrast is not between the house of David and the house of Saul, as one might expect after the first half of the verse, but between David and the house of Saul. This is significant for at least two

\footnotetext{
${ }^{21}$ In light of this, it does not seem insignificant that Absalom is mentioned at the very center of the list in 2 Sam 3:2-5 and that he gets the most detailed introduction of all of David's sons.

${ }^{22}$ Fokkelman, Throne and City, 63-64.
} 
reasons. First, by pitting David alone against the entire house of Saul, the narrator once again emphasizes David's strength. ${ }^{23}$ Second, the telling omission of Ish-boshet as David's counterpart as well as the plural verbs associated with the house of Saul (in contrast to the singular verbs associated with David), reflect negatively on Ish-boshet and his kingship and suggest a lack of leadership and unity in the house of Saul, thus fittingly illustrating the weakness of that house which is noted in that very line. ${ }^{24}$ This weakness is further underscored and explained by the designation "house of Saul," since in this way Ish-boshet's kingship is associated with a dead and rejected king. David, on the other hand, is very much alive and chosen by God.

\section{Verses 2-5}

Verse 2

The contrast between David and the sons of Zeruiah is further emphasized at the beginning of v. 2. While at the end of 2 Sam 2, a son, namely Asahel, is buried by his brothers in the tomb of his father, David becomes the father of sons at the beginning of 2 Sam $3{ }^{25}$ While one family is decimated, the other family grows. As was noted above, the birth list seems to have been intentionally placed here to illustrate David's increasing strength mentioned in v. 1. This is significant, for it once again shows that David does not seek to gain strength by violent means. The one thing that is reported about him during the long war is that he procreated and thus became an agent of life. His fruitfulness is

\footnotetext{
${ }^{23}$ Youngblood, “1 \& 2 Samuel,” 828.

${ }^{24}$ Fokkelman, Throne and City, 64; Auld, I \& II Samuel, 373.

${ }^{25}$ Note also that the last "sons" mentioned in previously were the "sons of Zeruiah" (2 Sam 2:18).
} 
reminiscent of Hannah's back at the very beginning of 1 Samuel. Including Samuel, a total of six children are born to her as well (1 Sam 2:21). ${ }^{26}$ Yet while her children are all fathered by her husband Elkanah, David's sons are from six different wives and of none of the sons it is said that they grew before the Lord like Samuel (1 Sam 2:21). That David fathers sons with multiple women also once again connects him to Jacob who has twelve sons from four different women (Gen 35:23-26). Given the strife that existed in Jacob's family the question arises whether the same will happen in David's family. Thus, the parallels to Hannah and Jacob hint at the problems associated with these births that were already noted above and cast an ominous shadow over David's growing family.

The names of the sons and their mothers now follow in quick progression. The first son that is mentioned is Amnon whose mother is Ahinoam the Jezreelitess. He is explicitly designated as David's firstborn. Intruigingly, the exact form בְכוֹרוֹ occurs only twice previously in the Old Testament, namely in Judg 8:20 in reference to Jether, the firstborn son of Gideon and in Gen 38:6 in reference to Er, the firstborn son of Judah. While this terminological link by itself may not warrant the conclusion that an allusion to these previous stories is intended at this particular point in 2 Samuel, further thematic parallels which emerge when the narratives in Gen 38 and Judg 8 are compared with the story of David and his sons that begins in 2 Sam 3:2-5 raise the possibility that the link may be intentional after all. It may not be coincidental, for example, that the expression

\footnotetext{
${ }^{26}$ The connection between David and Hannah is further strengthened by the fact that previous to 2 Sam 3, the verb ירָי only occurs in connection with Phinehas' wife (1 Sam 4) and Hannah (1 Sam 1-2) in 1-2 Samuel. Note also the similar dynamic of one house growing progressively stronger by means of births (Hannah's), while another house grows progressively weaker by means of deaths (Eli's).
} 
בכבוֹרוֹ issue of kingship first comes up (see Judg 8:18, 22ff.). ${ }^{27}$ Like Gideon in Judg 8 David rejects the temptation to grasp for kingship over Israel but instead recognizes the kingship of YHWH. Yet, like Gideon (Judg 8:30), David also takes many wives who bear him multiple sons and one of those sons kills his own brother and subsequently seeks to become king just like Gideon's son Abimelech in Judg 9. In the context of 2 Sam 3:2-5 the parallels to the story of Gideon thus reflect more negatively than positively on David and ominously foreshadows the "conflict that will nearly tear David's kingdom apart."28

The same is true of the link to Gen 38, which connects David with Judah. While the association of David with Judah could be viewed as reaffirming the divine election of David as ruler over his brothers (see Gen 49:8-12), the verbal link to this particular episode in Judah's life once again highlights David's departure from the divine ideal regarding marriage and hints at the family problems that will result from this. Like Judah, David marries a pagan woman and as in the case of Judah, his firstborn son is connected to a woman named Tamar and does not do what is right in the eyes of the Lord, leading to his premature death (Gen 38; 2 Sam 13). ${ }^{29}$ In light of this, Amnon's name, which means "faithful," becomes highly ironic.

\footnotetext{
${ }^{27}$ Certain parallels between David and Gideon are already evident in 1 Samuel. Both are divinely chosen even though they are the youngest in the family (Judg 6:15; 1 Sam 16:11), both are filled with the Spirit of YHWH (Judg 6:34; 1 Sam 16:13) and both fight against Israel's enemies, winning an unlikely victory with just a few hundred men against a numerically far superior force (Judg 7; 1 Sam 30).

${ }^{28}$ Firth, $1 \& 2$ Samuel, 342.

${ }^{29} \mathrm{~A}$ useful summary of the parallels between the family stories of Judah and David is found in Craig Y.S. Ho, "The Stories of the Family Troubles of Judah and David: A Study of their Literary Links," Vetus Testamentum 49 (1999): 514-31.
} 
Verse 3

The second son that is listed is Chileab. Some uncertainty surrounds his name, since he is called "Daniel" in 1 Chronicles 3:1 and Josephus, "Daluiah" in the LXX and "Abiah" in some later Greek versions. ${ }^{30}$ Because of this, some have suggested that “Chileab" may be a nickname. ${ }^{31}$ Various meanings have been suggested for the name. While some argue that it is a shortened form of יכל אב ("the father prevails"), others propose that the name means "entirely the father" or "all of the father." 32 Still others relate the first part of the name to the verb כלה בל and therefore read "accomplished of the father." ${ }^{, 33}$ Possibly the most intriguing proposal is that the first part of the name is a truncated form of the verb פל בלא and that the name thus means "restraint of the father."34 Interestingly, the verb פלא appears in 1 Sam 25:33 where David praises Chileab's mother Abigail for restraining him from bloodguilt and from helping himself with his own hand. Chileab's name may thus have been both a reminder of that event as well as an expression of David's attitude with regard to gaining kingship by force, presenting yet another striking contrast to the grasping for power and supremacy that takes place in the

\footnotetext{
${ }^{30}$ Cartledge, 1 \& 2 Samuel, 385; Anderson, 2 Samuel, 48; vom Orde, Das zweite Buch Samuel, 53; Vannoy, 1-2 Samuel, 279.

${ }^{31}$ See e.g. Wilhelm Rudolph, Chronikbücher (Tübingen: Verlag J.C.B. Mohr Paul Siebeck, 1955), 27; Smith, A Critical and Exegetical Commentary, 357.

${ }^{32}$ For the former interpretation see e.g. Jacob Myers, 1 Chronicles, AB 13 (Garden City, NY: Doubleday, 1965), 17. For the latter interpretation see e.g. Rudolph, Chronikbücher, 27.

${ }^{33}$ See. e.g. Alfred Jones, Jones Dictionary of Old Testament Proper Names (Grand Rapids, MI: Kregel Publications, 1990), 87.

${ }^{34}$ See e.g. Horace J. Wolf, “Chileab,” ISBE 1:611.
} 
narrative just before the birth list. At the same time, however, the name would also be ironic in the context of the birth list, since David does not appear to show much restraint with regard to taking wives. Significantly, David's departure from the divine ideal in this regard begins precisely with his marriage to Abigail. ${ }^{35}$

Located at the very center of the birth list are Absalom and Adonijah, both of whom will later grasp for the kingship while their father is still alive. ${ }^{36}$ Absalom is further highlighted by the fact that his introduction is the longest and most detailed of all the sons. His name ("the father is peace") associates David and his kingship with peace, once again contrasting with the lack of peace in the preceding literary unit. Ironically, however, of all of David's sons, it is precisely Absalom who will be most responsible for destroying David's peace later in 2 Samuel. His future role is foreshadowed by the fact that he is called "the son of Maacah," since the name "Maacah" means "oppression." 37 Absalom's mother is further introduced as "the daughter of Talmai, the king of Geshur." By marrying her, David thus not only takes yet another wife but also marries a Canaanite woman of a people that Israel failed to expel from the land at the time of the conquest (Josh 13:13). Interestingly, the only previous occurrences of the name Talmai are also found in the context of the conquest (Num 13:22; Josh 15:14; Judg 1:10) and all refer to one of the sons of Enak whom Caleb drove out of Hebron (Josh 15:14). The contrast to Caleb further highlights how problematic David's course is. While Caleb drove out

\footnotetext{
${ }^{35}$ In light of this, it may not be accidental that Abigail is referred to as the wife of Nabal every time she appears after 1 Sam 25, including in 2 Sam 3:3, and that Nabal's name means "fool."

${ }^{36}$ The similarity between these two sons is further emphasized by the fact that both provide themselves with chariots, horses and fifty men who run before them (2 Sam 15:1; $1 \mathrm{Ki} \mathrm{1:5).}$

${ }^{37}$ Jones, Jones Dictionary, 229.
} 
Talmai from Hebron so that the Canaanites would not oppress Israel, David marries a daughter of Talmai while ruling from Hebron and the result of that union is a "son of oppression" who will drive David from the land. A marriage that, as noted above, was most likely intended to strengthen David's position, in the end thus results in the exact opposite because David repeats the mistake of Israel and fails to finish the conquest.

Verse 4

Following Absalom in the birth list are Adonijah and Shephatiah. Like Absalom, they are not introduced as "his" (i.e. David's) sons as Amnon and Chileab were, but as the sons of their mothers. Both also have theophoric names that include a Yahwistic element, with Adonijah meaning either "YHWH is Lord" or "My Lord is YHWH" and Shephatiah meaning "YHWH has judged." Both names thus associate David and his kingship with the belief that YHWH is the true lord and judge. Ironically, it is precisely this truth that David appears to forget as he takes multiple wives. Like the names of all the other sons, the names of these two sons therefore reflect both positively and negatively on David and his kingship.

\section{Verse 5}

The list closes with David's sixth son Ithream whose name means "rest/remnant of the people." Like his half-brothers Chileab and Shephatiah, he is not mentioned again in the following narrative. His mother Eglah is called "David's wife," the only woman in the list to be specifically designated in this way. ${ }^{38}$ The literary unit then ends with a

\footnotetext{
${ }^{38}$ Various reasons for this have been suggested, none of which are entirely convincing. The most common suggestion is that Eglah is so designated simply because she is the last woman in the list. See e.g. 
statement that reiterates what was already stated at the beginning of the birth list, namely that all of the six sons mentioned were born to David at Hebron.

\author{
Implications for the Nature of David's Kingship
}

After his notable absence from the events at Gibeon in 2 Sam 2:12-32, David returns to the scene in the present literary unit. Though at first glance David and his kingship continue to appear in a very positive light in this unit, a close reading of the text reveals a more nuanced picture. While the passage once again highlights many positive aspects of David and his kingship, almost all of these aspects are tainted or even reversed by David's departure from the divine ideal in the area of marriage, casting an ominous shadow over the success and continuity of his kingship.

\title{
The Legitimacy of David's Kingship
}

Chosen by $Y H W H$. David's divine election is indirectly highlighted through the contrast between him and the house of Saul in 2 Sam 3:1. The emphasis on Saul instead of Ish-boshet associates Ish-boshet's kingship with death and divine rejection. The chosen David, on the other hand, is associated with life. Both aspects (divine election and

Alter, The David Story, 209; Cartledge, 1 \& 2 Samuel, 385; Smith, A Critical and Exegetical Commentary, 358. Youngblood, "1 \& 2 Samuel," 830, further speculates that "her relationship...summarizes that of the other women." See also vom Orde, Das zweite Buch Samuel, 53. Others conjecture that the specific designation as David's wife indicates that Eglah was either David's favorite wife or the head wife of his harem. See e.g. Smith, A Critical and Exegetical Commentary, 358 and Hertzberg, I \& II Samuel, 254. Yet another suggestion is that "in an earlier form of the text she was David's half sister or 'wife' of an unknown man." Hertzberg, I \& II Samuel, 254. However, such “conjectures...cannot be substantiated." (Hertzberg, I \& II Samuel, 254). From a literary viewpoint the designation may be intended to both provide a contrast to the concubine of Saul mentioned in 3:7, thus once again emphasizing the difference between the two kingdoms (see the analysis of 3:7 below), as well as highlight the fact that the previous three women in the list are never specifically called David's wives, thus subtly distancing them as well as their sons from David. This may be significant in light of Absalom and Adonijah's ambitions to succeed David on the throne later in the narrative. 
life) may be further emphasized through the association of David with Judah and Gideon, both of whom are divinely chosen to lead Israel and father multiple sons in the passages just mentioned. At the same time, however, the similarities to these earlier narratives also highlight David's departure from the divine ideal regarding marriage and foreshadow the negative consequences this will have for his family.

Qualified by his character. David's fruitfulness in the present literary unit sets him apart from the selfish attitude displayed by the protagonists in 2 Sam 2:12-32 that leads to death. Instead of strengthening himself at the expense of others, David gains strength by giving life to others. Instead of grasping for headship, he continues to exercise restraint. If Chileab indeed means "restraint of the father", the name of David's second son would further emphasize this attitude. In that case, the name would at the same time highlight David's lack of restraint in the area of marriage in this literary unit, however.

\section{Foundational Elements of David's Kingship}

Fruitfulness and Life. The report of the birth of six sons in this literary unit associates David and his kingship with fruitfulness and life. These two closely related elements are further emphasized by (1) the central placement of the birth list in the unit, (2) at least four of the names mentioned in the list and (3) the contrast to Ish-boshet, who does not appear to have any wives or children - and therefore no successor! - and whose kingship is thus associated with impotence and death. David's fruitfulness, on the other hand, is reminiscent of that of both Hannah and Jacob. The comparison with these two individuals also reflects negatively on David, however, as it highlights his decision to 
take multiple wives and hints at the negative consequences this will have for him and his family.

Strength and Continuity. David's strength is not only explicitly stated in 2 Sam 3:1, but also subtly emphasized by the form of the same verse, as David alone is set in contrast to the entire house of Saul. In addition, the strength of his kingship is illustrated by the birth list which mentions six potential successors to David's throne, thus increasing the likelihood that his kingship will endure. Ish-boshet, on the other hand, does not appear to have a successor. Instead his kingship is associated with his dead and rejected father Saul, while Ish-boshet is not even mentioned. The weakness of his kingship is further highlighted by the plural verbs associated with the house of Saul, suggesting a lack of leadership and unity.

In spite of the stark contrast between David and Ish-boshet, however, David's strength is not entirely unproblematic, since it is at least in part achieved by a departure from the divine ideal regarding marriage and possibly a questionable alliance with a Canaanite king. In the end, this strength does not ensure the continuity of his kingship as none of the six sons mentioned in the birth list succeed him on the throne of Israel.

Peace. The name of his third son Absalom as well as the contrast between the description of David's family in 2 Sam 3:2-5 and the report about the war between brothers in the preceding narrative at first glance once again associates David and his kingship with unity and peace. Instead of fighting against his fellow Israelites, he starts a family. Yet the fact that this family includes six sons from six different women and the parallels to the families of Jacob, Judah and Gideon already hint at the fragility of this 
peace and prepare the reader for the strife that will characterize David's family and his kingship in the future.

Disobedience to God and his law. While the names of David's sons Adonijah ("YHWH is Lord" or "My Lord is YHWH") and Shephatiah ("YHWH has judged") proclaim David's allegiance to YHWH, his course of action in this literary unit calls this allegiance into question, for by marrying multiple wives David not only departed from the divine ideal regarding marriage set forth at creation but also disregarded the divine command in Deut 17:17. For the first time his kingship is thus associated with disobedience to the divine law.

\section{The Purpose of David's Kingship}

Finish the conquest. The parallels between David and Gideon reinforce the impression gained in 2 Sam 2:1-11 that David is concerned with completing the conquest. This is called into question, however, by his marriage to Maacah. In contrast to Caleb who drove out the Canaanites from Hebron, David marries the daughter of a Canaanite king and fails to finish the conquest. As in the case of Israel, this neglect will eventually force him to depart from the land.

\section{Samuel 3:6-39}

Text

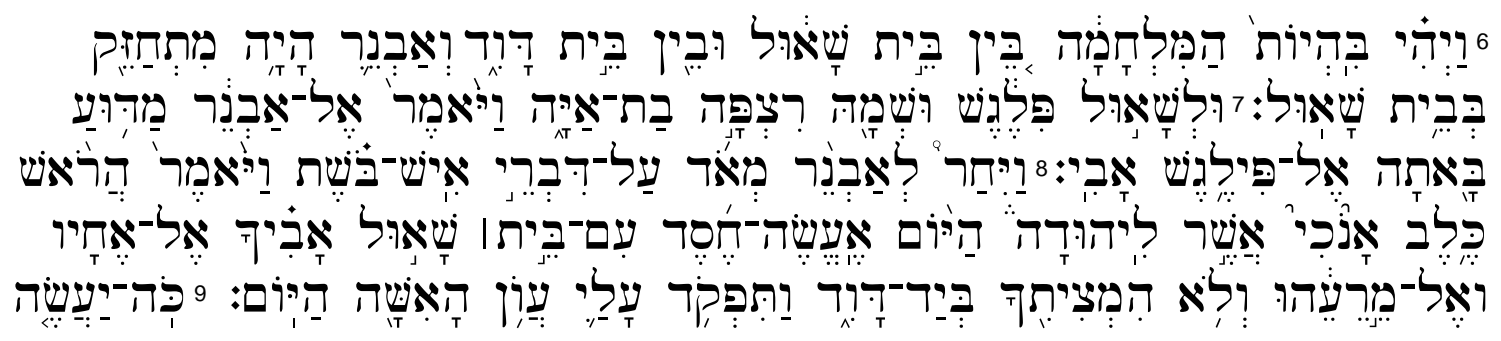




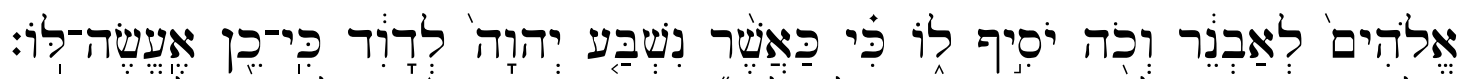

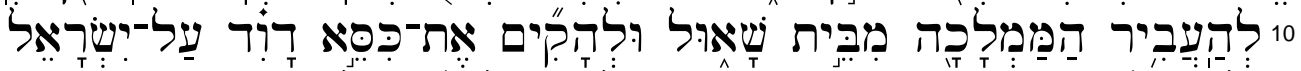

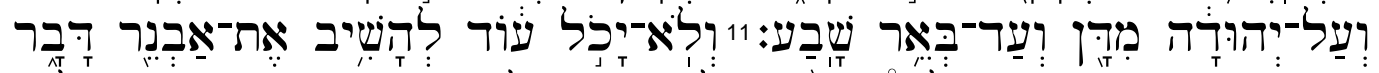

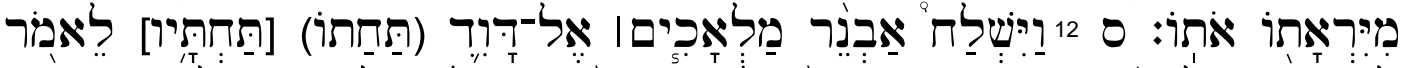

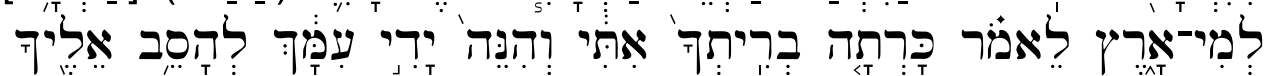

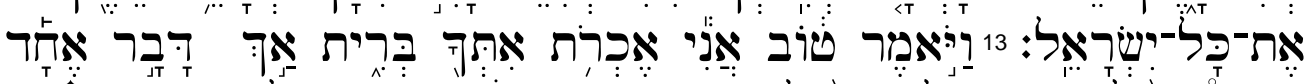

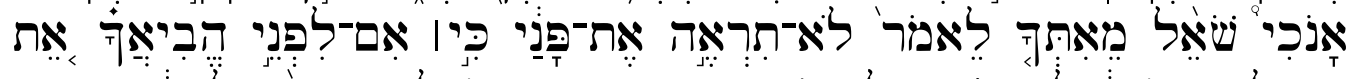

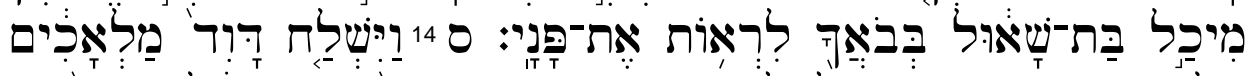

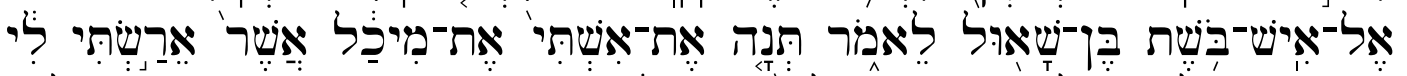

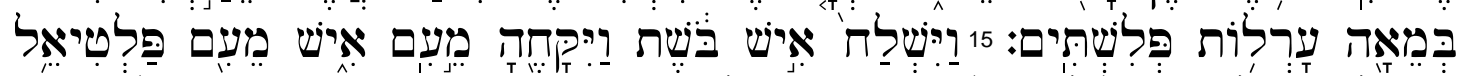

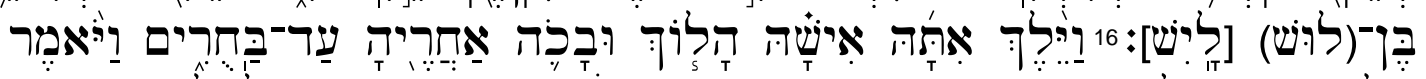

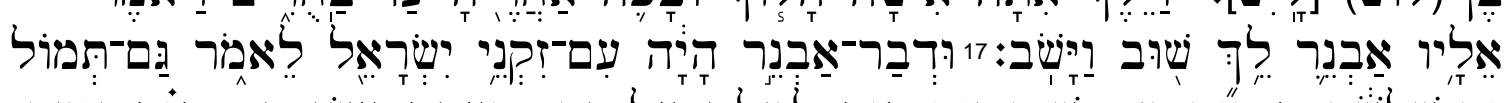

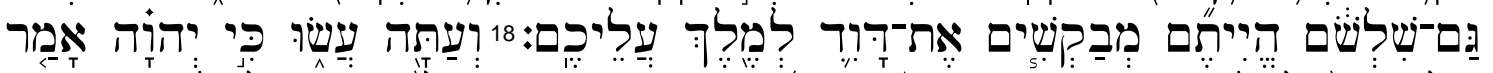

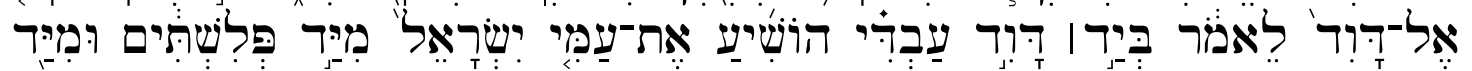

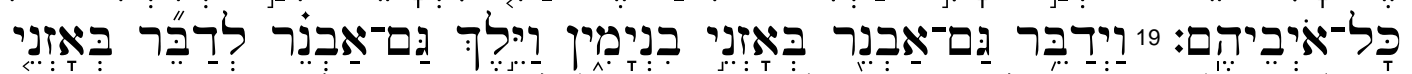

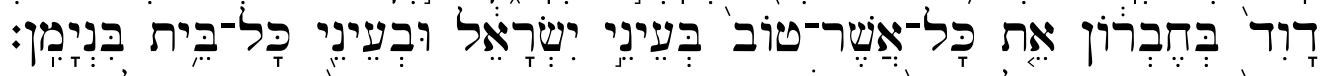
20

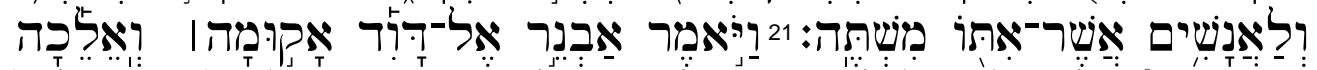

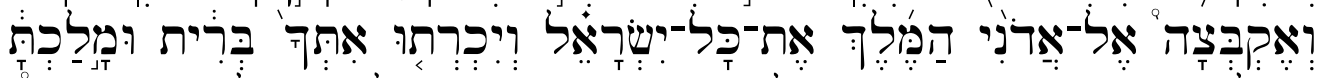

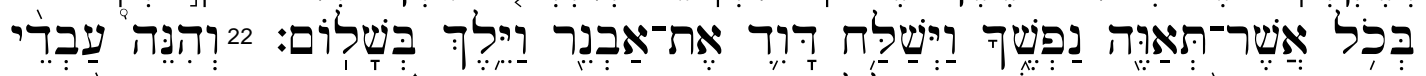

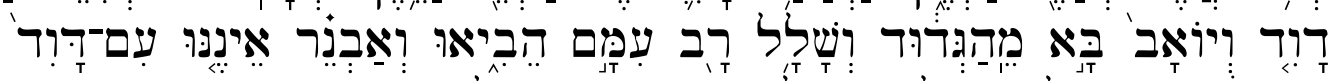

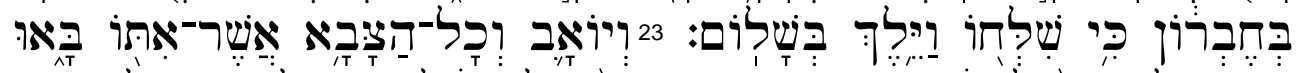

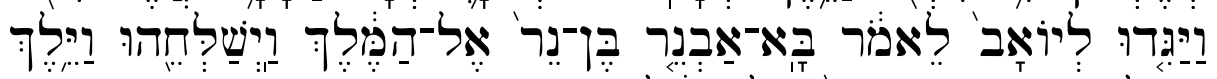

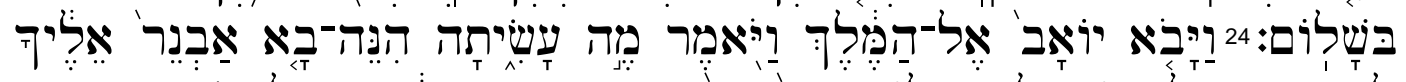

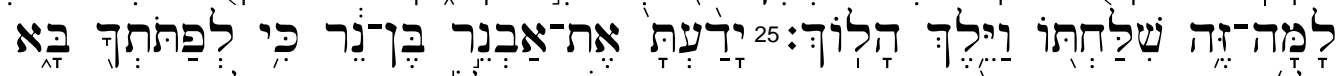

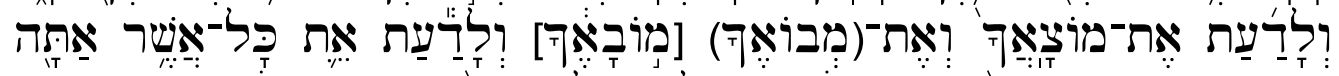

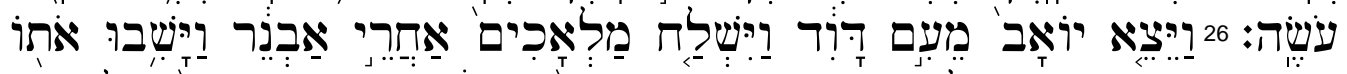

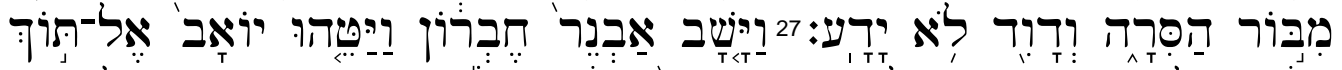

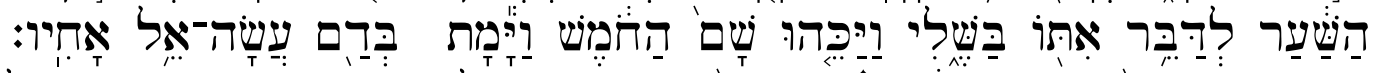

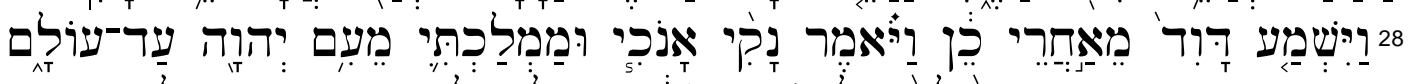

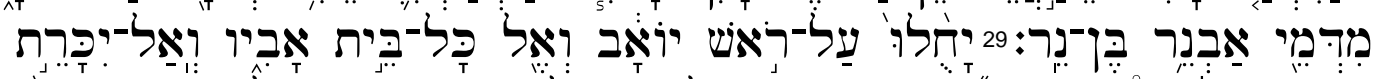

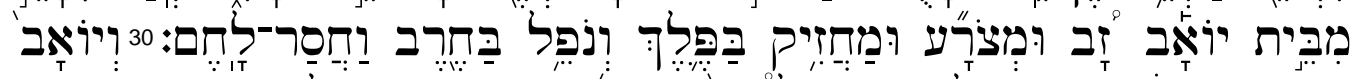

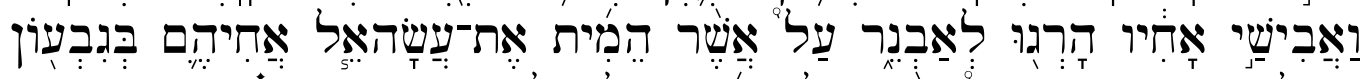

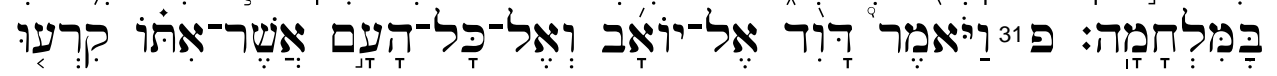




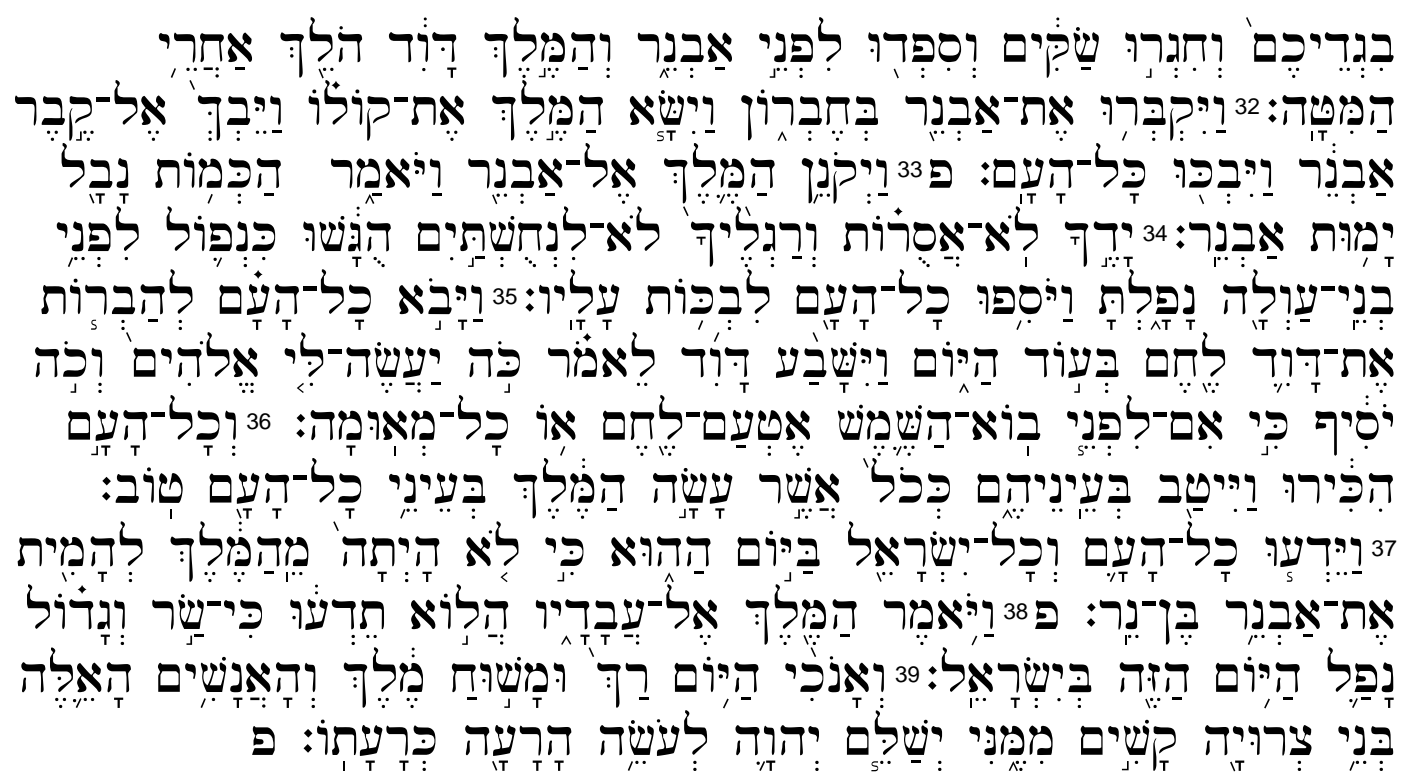

Translation

${ }^{6}$ Now it came about while there was war between the house of Saul and the house of David that Abner was making himself strong in the house of Saul. ${ }^{7}$ And Saul had a concubine whose name was Rizpah, the daughter of Aiah. And he said to Abner: Why have you gone in to my father's concubine? ${ }^{8}$ Then Abner became very angry over the words of Ish-boshet and said: Am I a dog's head that belongs to Judah? Today I show loving-kindness towards the house of Saul, your father, to his brothers and to his friends and I have not caused you to fall into the hand of David, yet today you call me to account for an offense concerning the woman? ${ }^{9}$ So may God do to Abner and so may he add to him: as the Lord swore to David, thus I will do for him, ${ }^{10}$ to make the kingdom pass from the house of Saul and to raise up the throne of David over Israel and over Judah, from Dan to Beersheba. ${ }^{11}$ But he was once again unable to return Abner a word, because he was afraid of him. ${ }^{12}$ Then Abner sent messengers in his place to David, saying: To whom does the land belong? Saying: Make your covenant with me! Behold, my hand will be with you to make all Israel turn to you. ${ }^{13}$ And he said: Good! I will make a covenant with you. However, one thing I request of you, saying: You shall not see my face unless before you bring Michal, Saul's daughter, when you come to see my face. ${ }^{14}$ And David sent messengers to Ish-boshet, the son of Saul, saying: Give my wife Michal whom I betrothed to myself for one hundred foreskins of the Philistines. ${ }^{15}$ Then Ish-boshet sent and took her away from a man, away from Paltiel the son of Laish. ${ }^{16}$ But her husband went with her, walking and weeping behind her until Bahurim. Then Abner said to him: Go, return! So he returned. ${ }^{17}$ But the word of Abner had been with the elders of Israel, saying: In times past you were seeking David to be king over you. ${ }^{18}$ Now then, take action for the Lord has spoken regarding David: By the hand of my servant David I will save my people Israel from the hand of the Philistines and from the hand of all their enemies. ${ }^{19}$ And Abner spoke also in the ears of Benjamin. Then he also went to speak in the ears of David in Hebron all that was good in the eyes of Israel and in the eyes of the 
whole house of Benjamin. ${ }^{20}$ When Abner came to David at Hebron, and with him twenty men, David made a feast for Abner and the men who were with him. ${ }^{21}$ Then Abner said to David: I will arise and I will go and I will gather to my lord, the king, all Israel, that they may make a covenant with you and you may reign over all that your soul desires. So David sent Abner away and he went in peace. ${ }^{22}$ And behold, the servants of David and Joab came from a raid and brought much spoil with them. But Abner was not with David in Hebron, for he had sent him away and he had gone in peace. ${ }^{23}$ When Joab and all the army that was with him came, they told Joab, saying: "Abner the son of Ner came to the king and he sent him away and he has gone in peace. ${ }^{24}$ Then Joab came to the king and said: "What have you done? Behold, Abner came to you. Why did you sent him away and he went, going off? ${ }^{25}$ You know Abner, the son of Ner, that he came to deceive you and to know your going out and your coming in and to know all that you do. ${ }^{26}$ And Joab went out from David and sent messengers after Abner, and they brought him back from the cistern of Sirah. But David did not know. ${ }^{27}$ When Abner returned to Hebron, Joab turned him aside into the middle of the gate to speak with him privately, and there he struck him in the belly that he died on account of the blood of Asahel his brother. ${ }^{28}$ When David heard afterwards, he said: Innocent am I, and my kingdom, before the Lord forever of the blood of Abner, the son of Ner. ${ }^{29}$ May it come down on the head of Joab and all his father's house, and may there not be cut of from the house of Joab one who has a discharge or who is a leper or who takes hold of a distaff or who falls by the sword or who lacks bread. ${ }^{30}$ So Joab and his brother Abishai murdered Abner because he had killed their brother Asahel at Gibeon in battle. ${ }^{31}$ Then David said to Joab and to all the people that were with him: Tear your garments and gird on sackcloth and lament before Abner. And King David walked behind the bier. ${ }^{32}$ So they buried Abner in Hebron. And the king lifted up his voice and wept at the grave of Abner, and all the people wept. ${ }^{33}$ And the king lamented over Abner and said: Should Abner die as a fool dies? ${ }^{34}$ Your hands were not bound nor were your feet put in fetters. As one falls before sons of wickedness you have fallen. Then all the people wept over him even more. ${ }^{35}$ Then all the people came to persuade David to eat bread while it was still day. But David swore, saying: So may God do to me, and more also, if I taste bread or anything else before the sun goes down. ${ }^{36}$ And all the people took note and it was good in their eyes, as everything the king did was good in the eyes of all the people. ${ }^{37}$ So all the people understood that day that it was not of the king to kill Abner the son of Ner. ${ }^{38}$ And the king said to his servants: Do you not know that a prince and a great one has fallen this day in Israel? ${ }^{39} \mathrm{But} \mathrm{I}$ am weak today, though anointed king, so that these men the sons of Zeruiah are too difficult for me. May the Lord repay the one who does evil according to his evil.

\section{Delimitation}

As in the case of 2 Sam 3:1, it is not an easy task to decide whether the transitional statement in 3:6 serves as the conclusion of the previous literary unit or the introduction of the following one. In spite of the significant terminological parallels 
between v. 6 and v. 1 which could be cited as evidence in favor of the former view, the latter position nevertheless seems preferable, for the following reasons: (1) As Youngblood correctly notes, "v. $6 \mathrm{a}$ is thematic of the rest of chapter 3 and all of chapter 4 in its reminder of the continuing struggle between the Saulides and the Davidides." ${ }^{39}$ (2) Abner, who is mentioned in v. 6b, plays a significant role in the following narrative but does not appear in the previous literary unit. (3) More specifically, the statement about Abner in v. $6 \mathrm{~b}$ prepares for the following narrative in that it "implies that Abner is not only well-positioned to wrest Israel's kingdom from the hapless Ish-Bosheth but also to do with it whatever he pleases - including deliver it to David." ${ }^{\text {40 }}$ (4) The statement about Abner's position of strength within the house of Saul is aptly illustrated by the immediately following encounter between Abner and Ish-boshet in vv. 7-11. For these reasons the present literary unit is viewed as commencing with v. 6 .

While this view is shared by most commentators, there is no consensus where the literary unit ends. Two positions dominate: whereas some see the literary unit as running all the way to the end of the chapter in v. 39 , others propose that it already ends in v. 21 , with another, closely related but nevertheless separate unit consisting of vv. 22-39 following. ${ }^{41}$ A careful reading of the text suggests that the former view is to be preferred.

${ }^{39}$ Youngblood, “1 \& 2 Samuel,” 833.

${ }^{40}$ Youngblood, "1 \& 2 Samuel,” 833.

${ }^{41}$ For the former view see e.g. Firth, $1 \& 2$ Samuel, 343; Stolz, Das erste und zweite Buch Samuel, 197; Arnold, 1 \& 2 Samuel, 437; McCarter, II Samuel, 103; Birch, "First and Second Books of Samuel," 1219; Campbell, 2 Samuel, 41; Smith, A Critical and Exegetical Commentary, 358; Anderson, 2 Samuel, 51. For the latter position see e.g. Cartledge, $1 \& 2$ Samuel, 386; Brueggemann, First and Second Samuel, 225; Youngblood, "1 \& 2 Samuel," 832; Bergen, 1,2 Samuel, 306; Vannoy, 1-2 Samuel, 280; Fokkelman, Throne and City, 67. Other ending points that have been suggested are v. 27 (Morrison, 2 Samuel, 46) and v. 30 (Auld, I \& II Samuel, 374). 
Though it is true that a new phase of the narrative begins in v. 22, the following verses up to v. 39 are still part of the same narrative, as is indicated by the fact that these verses feature a number of distinct keywords and phrases that also appear in the first half of the narrative. ${ }^{42}$ The unity of the narrative is further affirmed by its structure which encompasses both vv. 6-21 and vv. 22-39 as shown below.

\section{Structure}

The narrative opens with a scene featuring Abner and Ish-boshet (vv. 7-11) and closes with a scene featuring David, his servants and the people (vv. 35-39). A number of significant parallels between these scenes may be noted. First, both scenes are concerned with the wrong committed by a general and the king's reaction to it. Second, in both scenes the king is weak and his general stronger than him, as is demonstrated by the fact that in both scenes the king is unable to bring the general to justice. Third, in both scenes an oath is taken (vv. 9 and 35). Fourth, both scenes include an "I statement" by the main protagonist (vv. 8 and 39). ${ }^{43}$ Fifth, the keyword הַי occurs in both scenes (vv. 8, 35, 38, 39).

Following his exchange with Ish-boshet in the opening scene, Abner contacts David in order to enter into a covenant with him. This initial contact between Abner and

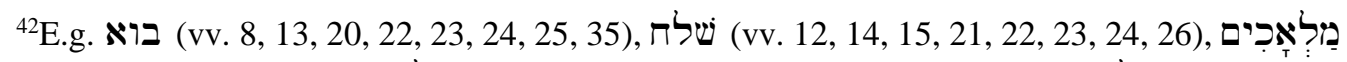

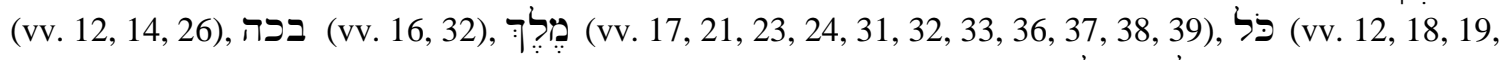

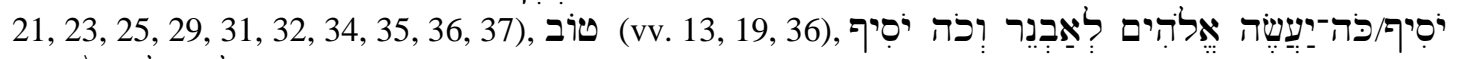

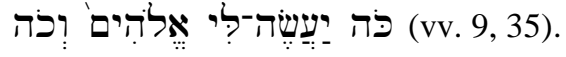

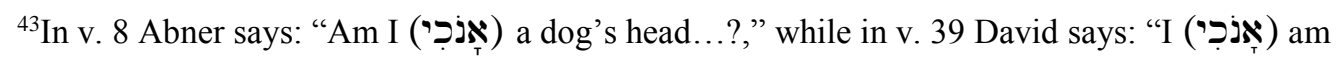
weak today..."
} 
David in vv. 12-16 is balanced by the final contact between the two at Abner's funeral (vv. 31-34). Again, there are several similarities that connect the two scenes. Most striking is the weeping and walking behind someone else that occurs in both scenes (vv. 16 and 31-32). Other parallels include (1) the keyword דָָּ that occurs in vv. 13 (3x), 31, and 34 and (2) the appearance of imperative verbs in vv. 12, 14, $16(2 x)$, and $31(3 x)$. Just before Abner's first visit to Hebron is recounted, the reader is informed about Abner's consultation with the elders of Israel in which he reminds them of their past desire to have David as their king and the divine prophecy regarding David's future role (vv. 17-18). The counterpart to this is David's "prophecy" regarding the future fate of Joab and his house which follows directly after the report about Abner's second visit to Hebron (vv. 28-29). The contrast between David and Joab is further highlighted by the information provided in v. 30, for while David is to save Israel by fighting against their enemies (v. 18), Joab and Abishai kill a fellow Israelite.

When Abner comes to Hebron he speaks to David (אמר) and is then sent (שלח) off by David and departs in peace (vv. 20-21). Similarly, when Joab comes to Hebron, he speaks (אפר) to David and then departs and sends (שלח) messengers after Abner (vv. 2426). It thus seems that vv. 22-23 constitute the center of the narrative. This makes sense, since the arrival of Joab is indeed the turning point of the story. At the same time these verses highlight the fact that Abner had gone away in peace.

In light of these observations the structure of this literary unit may be diagrammed as follows: 


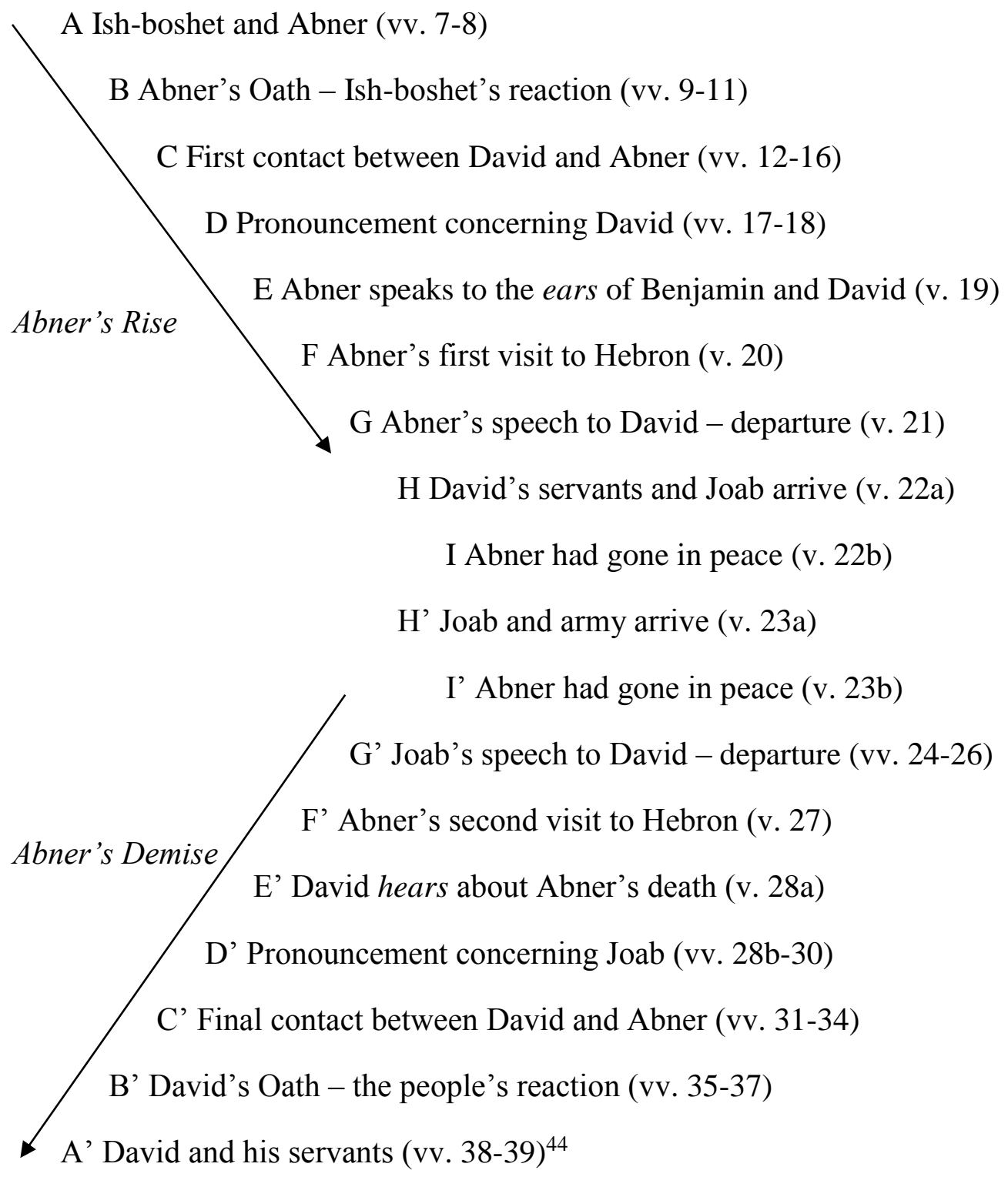

A' David and his servants (vv. 38-39) ${ }^{44}$ parallel panels:

${ }^{44}$ Alternatively, the central part of the narrative in vv. 20-27 could also be arranged into two

Abner comes to Hebron - men with him (20)

Abner speaks to David (21a)

David sends - Abner leaves in peace (21b)

Joab comes to Hebron - army with him (22-23)

Joab speaks to David (24-25)

Joab sends - Abner is killed (26-27)

This arrangement also highlights the contrast between the speeches of Abner and Joab as well as between the way David and Joab treat Abner. 
At the same time, the narrative may also be organized into two parallel panels.

Significantly, this structure confirms that vv. 22-23 are indeed the central verses of the narrative.

A General Abner and King Ish-boshet - king fails to respond (7-11)

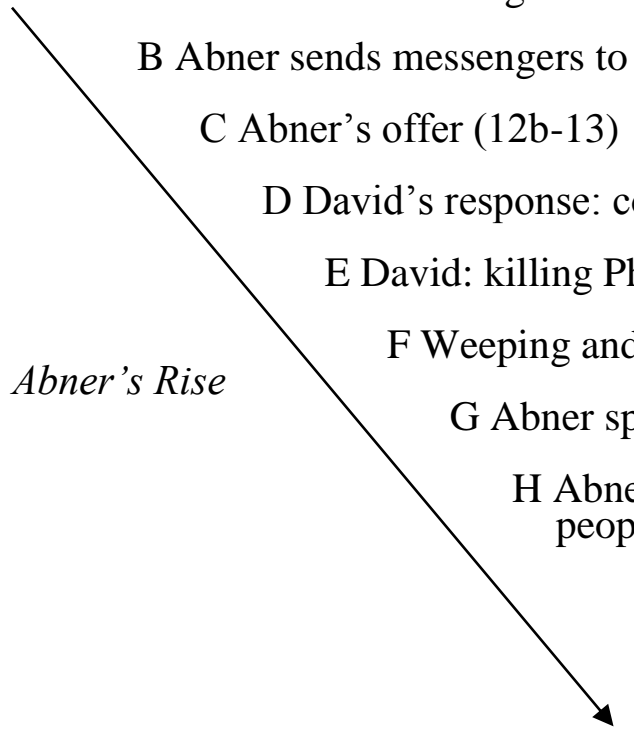

ake peace with David (12a)

C Abner's offer (12b-13)

D David's response: covenant prerequisite (13)

E David: killing Philistines for Michal (14)

F Weeping and walking behind (16)

G Abner speaks about David - People divided (17-18)

Abner speaks what is good in the eyes of the people - meal for Abner and his men (19-20)

I Abner's speech: David king over everything (21a)

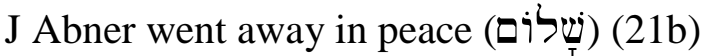

K Joab and army arrive (22a)

J'Abner had gone away in peace (22b)

K'Joab and army arrive (23a)

J"Abner had gone away in peace (23b)

\footnotetext{
A' General Joab and King David - king fails to respond (24-25)

B' Joab sends messengers to kill Abner (26)

C'Joab's deed (27)

D' David's response: covenant consequences (28-29)

E' Joab and Abishai: killing Abner for Abishai (30)

F' Weeping and walking behind (31-32)

Abner's Demise $\quad$ G' David speaks about Abner - People united (33-34)

H' David does what is good in the eyes of the people - no meal for David (35-37)

I' David's speech: David weak, though anointed king (38-39a)

J' May YHWH repay (שָׁ) (39b)
} 
Both structures highlight a number of things that are relevant with regard to the nature of David's reign:

1. Peace. In the central section of both structures Abner's departure in peace is emphasized. In the midst of war and bloodshed, the three-fold repetition of this fact highlights David's desire to end the conflict between brothers and gain kingship over a united Israel in a nonviolent way. As the parallel panel structure suggests, however, true and lasting peace in David's kingdom can only be brought about by YHWH himself.

2. The contrast between David and Ish-boshet. The contrast between the two kings that already became evident in previous literary units is highlighted once again by both structures of the present unit. The chiastic structure draws a connection between the opening and closing scenes of the narrative. In both scenes the kings are weak and their generals strong. Yet while Ish-boshet tries to hide his weakness by a temporary show of boldness, David openly admits his lack of power. Though, like Ish-boshet, he is unable to bring his general to justice, David does not fall silent in fear like the son of Saul, but instead calls on YHWH to execute justice on those who do evil. While Ish-boshet thus seems to be completely helpless and becomes passive once more, David remains active and knows where to turn for help.

This contrast is also emphasized by the parallel panel structure. Both panels begin with a scene in which a king is sharply criticized by his general and fails to respond. But while Ish-boshet remains passive and silent for the remainder of the first panel, David is only initially left speechless in the second panel. After Abner's death he becomes very active, publicly condemning Joab's deed and leading the people in mourning for the slain general. Thus, David is once more presented as the more capable and godlier leader who 
clearly recognizes and is not afraid to admit his own shortcomings and turns to YHWH for help. At the same time, however, the parallels between the two kings mentioned above suggest that the portrait of David in this unit is not completely positive and that he may at times be in danger of becoming like the son of Saul. It remains to be seen whether this initial impression will be confirmed by the close reading below.

3. The contrast between David and Abner. Both structures also highlight the contrast between David and Abner. The chiastic structure invites the reader to compare the oaths the two men swear. While both swear to do something for the other, the motivating spirit behind the oaths is very different. Whereas Abner's oath is the result of offended pride and spoken in a spirit of rebellion as he is about to betray his own king, David's oath is motivated by true sorrow and spoken in a spirit of respect for Abner as the people unite with their king in mourning. Also, while Abner's oath is focused on the grand thing he will do for David in order to further exalt himself, David's oath is focused on the humble thing he will do for Abner in order to further show his respect for the dead general. ${ }^{45}$ Thus the true character of David and Abner is revealed once again.

The difference between the two men is also brought to light by the parallel panel structure. Whereas Abner's speech about David to the elders of Israel and to Benjamin fails to fully convince the people to unite under David, David's speech about Abner and his acts of mourning for the dead general bring about unity among the people and cause

\footnotetext{
${ }^{45}$ Fokkelman, Throne and City, 113, also notes the contrast between David's fast and the fast ordered by Saul in 1 Sam 14. While Saul's command to fast is unreasonable and seemingly motivated by a spirit of selfish fanaticism, David's fast is highly appropriate and motivated by unselfish sorrow over Abner. It is also noteworthy that, in contrast to Saul, David does not appear to coerce the people to join him in fasting. Instead, he gives an example that others may follow if they so choose. Thus a comparison of the two scenes reveals the contrasting leadership styles of the two kings.
} 
them to look favorably on David. The contrast not only reaffirms that David is the more capable leader but also suggests that David's attitude of humility, respect and genuine sorrow over evil is a foundational element for the success of his kingship over a united Israel.

\section{Close Reading}

Following the slower pace of the tranquil interlude about the birth of David's sons at Hebron, the narrative picks up speed again. ${ }^{46}$ Once more, the war between the house of Saul and the house of David is mentioned, raising the question whether hostilities will continue indefinitely or whether one side will emerge victorious and if so, how this victory will be achieved. Thus, the stage is set for the drama that will now unfold.

\section{Verses 6-11}

Verse 6

The key player in this drama is Abner and it is he who reappears on the scene as the narrative gets underway in v. 6. As already noted above, the mention of his name in the structurally parallel position to David in 3:1 underscores his importance and together with the notable absence of Ish-boshet's name suggests that he is the de facto ruler of Ish-

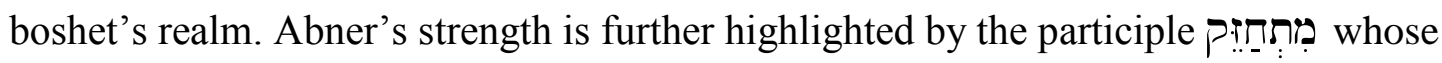
meaning in this context seems to be intentionally ambiguous. While on the one hand it can be understood positively, in the sense that Abner was faithfully supporting the house

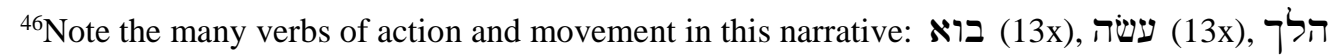

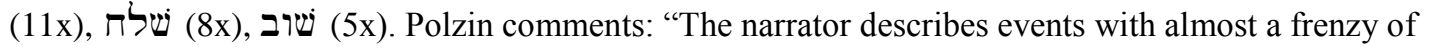
activity." (Polzin, David and the Deuteronomist, 35)
} 
of Saul (underscoring Abner's claims in v. 8), the immediate and larger context on the other hand suggest that it can also be interpreted negatively, in the sense that Abner was continuing to selfishly secure and strengthen his position within Saul's house to an inappropriate extent as he had been doing from the beginning of Ish-boshet's kingship. ${ }^{47}$ This does not bode well for what is to come.

\section{Verse 7}

Abner's strength and its negative consequences for the strength and continuity of Ish-boshet's kingship are immediately demonstrated in the scene that follows. In a surprising show of boldness, Ish-boshet accuses his general of sleeping with Saul's concubine Rizpah, an act that, as noted above, was tantamount to claiming the throne. ${ }^{48}$ That the reader is informed for the first time precisely at this point of the larger narrative in the Samuel books that Saul had a concubine is interesting, since it suggests that, like David, Saul also departed from the divine ideal regarding marriage, raising questions about the peace and unity of his kingship as in the case of David. Yet in spite of this similarity between Saul and David, the obvious contrasts must also be noted for the women associated with David are not referred to as concubines and there is no indication

\footnotetext{
${ }^{47}$ See e.g. Samuel Driver, Notes on the Hebrew Text and the Topography of the Books of Samuel (Oxford: Clarendon Press, 1913), 246: "The verb is not used elsewhere in a bad sense...but in the light of v. $8 \mathrm{ff}$. it is probable that it is used here to suggest the idea of acquiring undue power, and presuming too much." Note also Fokkelman's interpretation of the whole statement: "Abner behaved as if he were the boss in Saul's house." (Fokkelman, Throne and City, 68)

${ }^{48}$ Arnold, $1 \& 2$ Samuel, 437. Note also Leithart's comments on Ish-boshet's accusation: "This charge had both sexual and political dimensions. An ancient king's brides and concubines represented the kingdom in several respects. Because they constituted part of a king's household, wives and concubines were part of a king's inheritance, passed into the care if not into the bed of his successor (see 2 Sam. 12:8). Further, the king of Israel was seen as a husband to his people, so the wives of the king of Israel symbolized the national 'bride.' Protecting the bride symbolized the king's ability to protect the kingdom." (Leithart, A Son to Me, 189)
} 
that anyone had illicit sexual relations with them. Instead they bear sons to David and are thus presented as "mothers who... build up the strength of the 'house of David," "49 while no offspring is mentioned in connection with Rizpah, who causes division in the house of Saul that leads to its demise. ${ }^{50}$ Thus the weakness of Ish-boshet and his kingship is once again emphasized..$^{51}$

Ish-boshet's weakness is further highlighted by two other details in v. 7. First, as a number of scholars have noticed, Ish-boshet is not mentioned by name in this verse in the

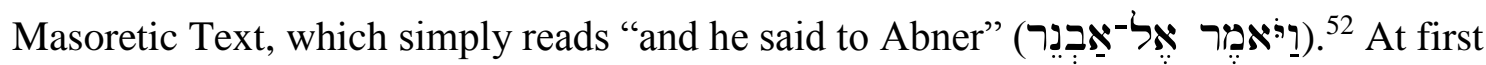
glance, the reader thus gets the impression as if Saul is addressing Abner, since he is the subject of the preceding statement. ${ }^{53}$ Only when the word אָז the question, does it become clear that Saul is not the speaker. Yet at the same time, this word (which is the second detail to be noted) once again focuses the reader's attention on Saul. Though Saul is dead, Rizpah is still presented as his concubine both by the narrator

${ }^{49}$ Fokkelman, Throne and City, 71.

${ }^{50}$ According to 2 Sam 21:8 Rizpah had at least two sons with Saul, yet this is not mentioned in 2 Sam 3.

${ }^{51}$ The appearance of a concubine in the context of a civil war also provides yet another connection to the story in Judges 19-21 which contains eleven of the sixteen previous occurrences of the term and also marked the last time the term occurred previously in the Old Testament. The verbal link to a story which highlights both the preeminent status of Judah among the tribes of Israel (see e.g. Judg 20:18) as well as the demise of Benjamin that begins with an illicit sexual encounter between Gibeanites and a concubine prepares the attentive reader for the rise of Judah and the demise of Benjamin in 2 Sam 3 that once again begins with an illicit sexual encounter between a member of the house of Saul who was from Gibea (see 1 Sam 10:11) and a concubine.

${ }^{52}$ Fokkelman, Throne and City, 72; Anderson, 2 Samuel, 53; vom Orde, Das zweite Buch Samuel, 54; Vannoy, 1-2 Samuel, 281.

${ }^{53}$ Note how this also distances Ish-boshet from the bold question he asks, thus weakening his association with any kind of strength, courage or authority that his question might suggest. 
as well as by Ish-boshet, who fails to claim her as his own. This reinforces the impression gained earlier (for example through the repeated references to Abner and Ish-boshet's side as "the house of Saul" instead of "the house of Ish-boshet"), namely that Ishboshet's kingship is strongly associated with the dead Saul, while Ish-boshet himself recedes into the background, to the point of "being forced out of the text."54

\section{Verse 8}

Abner responds to Ish-boshet's accusation with anger - a reaction that is reminiscent of Saul's behavior on several occasions in 1 Samuel and contrasts starkly with the peaceful preceding literary unit. ${ }^{55}$ The speech which follows in vv. $8 b-10$ is the longest in 2 Sam 2:1-5:5 and consists of two parts of equal length that surround Abner's oath in v. 9a. ${ }^{56}$ While the first part emphasizes Abner's past and present loyalty to the house of Saul, the second part focuses on Abner's future disloyalty to that house as he announces his intention to make David king over all Israel.

Instead of providing a straightforward answer to Ish-boshet's question, Abner begins his speech with a rhetorical question that clearly shows his disdain for the puppet king and the high view he has of himself: “Am I a dog's head that belongs to Judah?”

${ }^{54}$ Fokkelman, Throne and City, 72. Fokkelman continues: "This treatment of Ishbosheth is iconic for his weakness. His being omitted or suppressed, to which he contributes himself, iconically stands for the message that he is a nobody."

${ }^{55} \mathrm{Saul}$ is the subject of $\prod_{\tau}$ in four of the six previous appearances of the verb in 1 Samuel and Saul is the only previous individual in the Samuel books who became "very angry" (see 1 Sam 18:8 : מאד

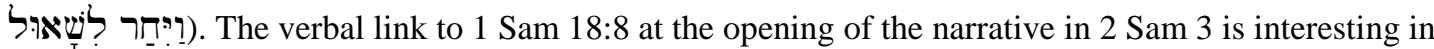

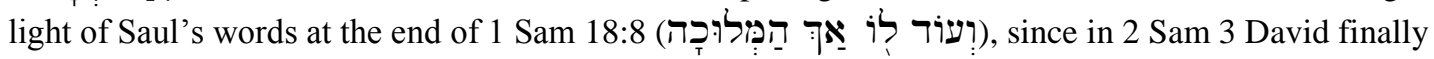
begins to receive the entire kingdom.

${ }^{56}$ Fokkelman, Throne and City, 73. The second longest is David's in 2 Sam 2:5-7. As will be shown below, there are significant points of contact between the two speeches. 
The question has generated much discussion as scholars have struggled in particular to

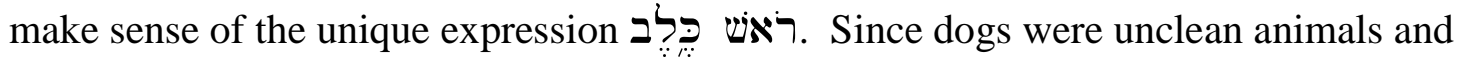
"generally despised in ancient Palestine," ${ }^{, 7}$ most commentators believe that the expression was some kind of insult by which something was designated as worthless or contemptible ${ }^{58}$ Significantly, one of the reasons for this attitude toward dogs may have been their sexual promiscuity. ${ }^{59}$ This is particularly interesting in the context of 2 Sam 3, not only because of the nature of Abner's alleged deed, but also in light of the fact that David has sexual relations with several different women in vv. 2-5. Given that (1) David belonged to Judah, (2) the term ראש is strongly connected to headship throughout Samuel and, as noted above, in particular in the immediate context of 2 Sam 3 and (3) David refers to himself as a dog in 1 Sam 24:15 (the last previous occurrence of the term

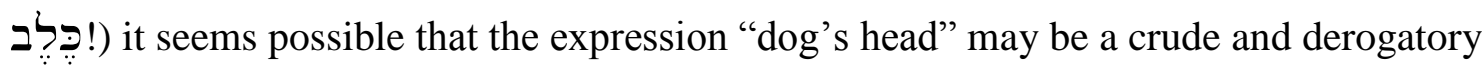
reference to David. Abner would thus be saying: "Am I David, who belongs to Judah and is sleeping with at least six different women?"${ }^{90}$ In that case Abner would be cleverly

\footnotetext{
${ }^{57}$ Bergen, 1,2 Samuel, 308.

${ }^{58}$ See e.g. Birch, "First and Second Books of Samuel," 1223; Robinson, Let Us Be Like the Nations, 164; Smith, A Critical and Exegetical Commentary, 359.

${ }^{59}$ The sexual promiscuity of dogs is noted, among others, by Anderson, 2 Samuel, 56 and Smith, A Critical and Exegetical Commentary, 359. This would also explain why male harlots seem to have been referred to as dogs (see Deut 23:19).

${ }^{60}$ If this interpretation is correct, the question is designed to emphasize that Abner is not like David. Careful attention to the wording of the question suggests that this is indeed the case, though not in the way Abner wants to make it appear. It is interesting, for example, that Abner's question is very similar to Goliath's question to David in 1 Sam 17:43: "Am I a dog that you come to me with sticks?" The parallel associates Abner with the haughty Goliath, who is David's enemy and will be killed by him - a fact that does not bode well for Abner's future. Not surprisingly, he is dead before the narrative is over - just like Goliath. In contrast to both Goliath and Abner, David - as already mentioned above - calls himself a dead dog during his speech to Saul in 1 Sam 24:15, the only other time in Samuel (besides 1 Sam 17:43) the
} 
shifting attention away from himself and his own alleged misdemeanor right from the beginning of his speech, while at the same time suggesting that not he, but David is the

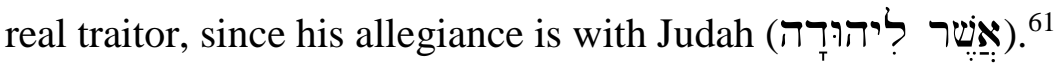

This interpretation of Abner's rhetorical question also fits well with Abner's next words in v. 8 which emphasize his loyalty to the house of Saul. After indirectly suggesting that David has been disloyal to Saul by becoming king over Judah, Abner reminds Ish-boshet that he, on the other hand, shows Saul's brothers and friends. While this may appear to be true on the surface, given that Abner has kept Saul's kingship alive by putting Ish-boshet on the throne, a careful reading of the text suggests the exact opposite. As the analysis of the previous literary units has shown, Abner's efforts to continue Saul's kingship seem to be motivated not so

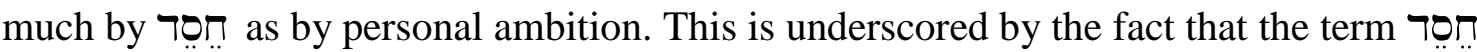
is nowhere else associated with Abner. Instead, the attentive reader is reminded of the last occurrence of the term in 2 Sam 2:5-6 where David commends the men of Jabesh-Gilead for showing חִִֶ to Saul and expresses his wish for the Lord to show to them in return. As noted in the analysis of that literary unit above, a careful reading of these

term כִ כִל occurs prior to 2 Sam 3. Like Abner, David is accused of seeking to harm the king (see 1 Sam 24:9), but unlike the proud general he responds with humility and persuasively proves that the charge is inaccurate. Thus the verbal links to 1 Sam 17 and 1 Sam 24 both highlight the superiority of David over Abner. At the same time, however, the parallels between Abner and David noted above show that David is in danger of departing from the course he follows in 1 Sam 24 and afterwards and becoming like Abner.

${ }^{61}$ As Bodner notes, Abner's question is "laced with a certain irony," since the remainder of the narrative demonstrates that Abner is indeed a dog's head who belongs to Judah. "Before too long, both

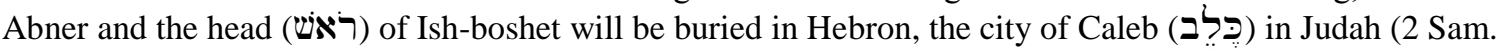
4.12)." Bodner, David Observed, 49. 
verses within their immediate context that takes into account the intertextual connections particularly to 1 Sam 26 reveals a striking contrast between David and the men of JabeshGilead on the one hand and Abner on the other hand, for while they showed and protected him, Abner failed to do so. Nevertheless, Abner commends himself for showing חְֶ, while David commends others for doing so. ${ }^{62}$

Abner also claims to have shown חִִֶ to Saul's brothers and friends. While this

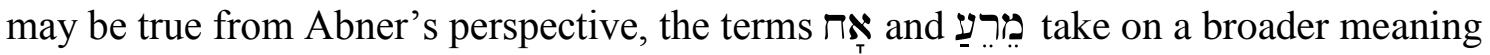
when read in the context of the larger narrative in Samuel. Both terms remind of the war between brothers (אָָ ) and companions (רָעָ) that was initiated by Abner in the previous chapter (see 2 Sam 2:16, 26-27), while the term מִּר adionally reminds of David, the

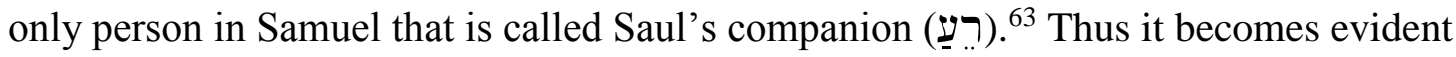
that Abner's statement is only half true at best. He may have shown חֶֶ? to Saul's literal brothers and certain of his friends, but he certainly did not do so to Saul's "brothers" from Judah or to Saul's companion David.

${ }^{62}$ Fokkelman, Throne and City, 78. That it was David, rather than Abner, who truly showed to the house of Saul is further emphasized by the verbal links to 1 Sam 24 both through the term Abner's question and the term הירו ה that occurs twice in 2 Sam 3:8. While four of the five occurrences of היi in 1 Sam 24 are directly associated with the kindness David showed to Saul by refusing to kill him in the cave (1 Sam 24:11,19, 20), Abner's use of היה is just as highly ironic as the question that precedes it, for in the very next verse he announces his intention to become disloyal to the house of Saul and switch his allegiance to David.

${ }^{63}$ See 1 Sam 15:28 and 28:17. The allusion to both of these passages at this particular point in the narrative is also significant because both address the transfer of the kingship from Saul to David that begins to become a reality in $2 \operatorname{Sam} 3$. 
It is only now that Abner finally gets to Ish-boshet, having side-stepped him at the beginning of his statement by identifying the house he showed boshet's father Saul, thus emphasizing that "the norm of his loyalty was in no way the son but the father." ${ }^{\prime 64}$ Ish-boshet is thus once more pushed aside and his kingship primarily associated with his dead father. But even now that he is finally mentioned, it is only as the object of a verb. ${ }^{65}$ The one who has the real power is once again Abner, who makes it clear that he could deliver Ish-boshet into David's hand at any time if he so chose. The implication is obvious: Ish-boshet should simply be thankful and content that he is still on the throne, even if he does not have any real power. ${ }^{66}$ This says much about the relationship between the king and his general and forcefully demonstrates once more the weakness of Ish-boshet's kingship.

Having reminded Ish-boshet of his loyalty to the house of Saul, Abner proceeds to go on the counterattack. Ish-boshet accused him; now Abner accuses Ish-boshet of accusing him in light of all he has done for the house of Saul, including Ish-boshet. Through his word choice he seeks to present Ish-boshet's accusation as an unfair und ungrateful act, for while Abner has shown (הַיוֹ) and has not caused Ish-boshet to be found (hiphil of

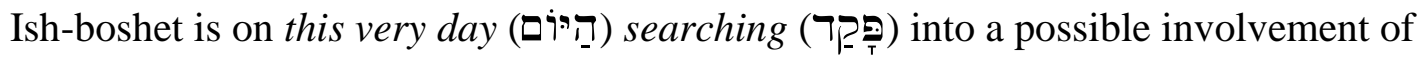

\footnotetext{
${ }^{64}$ Fokkelman, Throne and City, 74.

${ }^{65}$ Fokkelman, Throne and City, 74.

${ }^{66}$ Alter, The David Story, 210.
} 
Abner with Saul's concubine ${ }^{67}$ In other words, while Abner has hidden Ish-boshet, Ishboshet is seeking to expose Abner. Thus Abner has completely turned the tables on Ishboshet: the accuser has become the accused ${ }^{68}$ At the same time, Abner trivializes a possible tryst with Rizpah without ever clearly stating whether or not it actually happened. ${ }^{69}$ This becomes evident not only through the way his whole argument is set up to highlight the contrast between his loyalty to the house of Saul and his protection of Ish-boshet (a great and noble deed that certainly happened) and a possible sexual encounter with Rizpah (a trivial thing in comparison that may or may not have happened), but also through the fact that he refers to Rizpah simply as הָאָז mention that she is Saul's concubine, meaning that having sexual relations with her would amount to an act of treason.

Ironically, however, Abner's own words reveal the true character of such a deed. Sleeping with Rizpah would not have been a trivial thing and not even just an act of treason (i.e. an act of unfaithfulness to his king), but an act of "iniquity" (עָז) with a woman who was not Abner's wife (i.e. an act of unfaithfulness to his God). Significantly, as Youngblood has correctly noted, the combination עִ עָ used by Abner previously occurs "in a number of key theological texts" in the Old Testament where it always

\footnotetext{
${ }^{67}$ Fokkelman, 74: "In the eyes of the general Ishbosheth is inspecting or spying $(p q d) \ldots$...

${ }^{68}$ Note that this is the second time in Abner's speech that he has drawn attention away from the accusation again him by focusing on the faults of others. First, he indirectly accused David, now he indirectly accuses Ish-boshet. In Abner's world, everyone else is guilty or at least guiltier than he himself. This once again says much about his character.

${ }^{69}$ Alter, The David Story, 210; Hertzberg, I \& II Samuel, 257; Birch, "First and Second Books of Samuel," 1223; Firth, 1 \& 2 Samuel, 347.
} 
means "punish for sin/guilt/wickedness." ${ }^{\text {"70 }}$ One of these texts is Exod 34:7 where YHWH

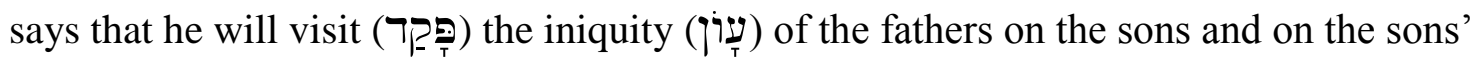

sons to the third and fourth generation. The terminological connection to this passage in a speech where Abner speaks about showing חֶֶֶ are interesting in light of the verbal links to Exod 34:6 in 2 Sam 2:5-6 where David speaks about showing חְּ?. Whereas David's kingship seems to be associated with the first part of YHWH's self-presentation that talks

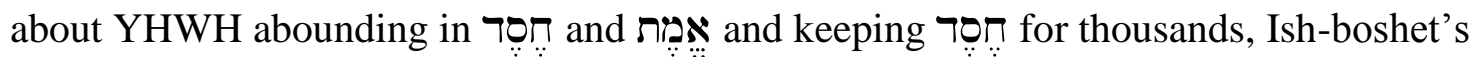
kingship appears to be associated with the second part that talks about YHWH punishing iniquity. In this way, the contrast between the two kingships is highlighted once again.

Verse 9

With his accusing rhetorical question to Ish-boshet still hanging in the air, Abner now delivers the decisive blow that marks the beginning of the end of Ish-boshet's kingship. In a completely unexpected and surprising move, the general announces that he will switch his allegiance to David and ensure that the latter will become king over all Israel. ${ }^{71}$ Once again Abner thus seeks to become the decisive force behind another's rise to power. To demonstrate how serious his intentions are, Abner introduces this second part of his speech with an oath that is in turn based on an alleged divine oath: "So may

\footnotetext{
${ }^{70}$ Youngblood, "1 \& 2 Samuel," 833.

${ }^{71}$ As surprising as this complete about-face may seem, Abner may have viewed it as his only chance to escape "the mortal threat of Ishbaal's accusation," (Morrison, 2 Samuel, 49) for by taking away Ish-boshet's kingship Abner also prevented him from exercising his kingly role as judge. Alternatively, Abner may have simply come to the realization that Ish-boshet's kingship was a lost cause and viewed Ishboshet's accusation as a chance to switch his allegiance to the winning side without losing face. Possibly, both motives played a role.
} 
God do to Abner and so may he add to him if as the Lord has sworn to David, so I do not do to him." ${ }^{, 72}$ While this may at first glance seem to be a commendable statement, a closer look raises the question how long Abner had known about YHWH's oath to David and why he did not act in harmony with this oath prior to being confronted with Ish-boshet's accusation. At the same time, Abner's statement once again focuses on himself as the one who will effectuate what YHWH has sworn. This close identification of Abner with YHWH once again reminds of David's message to the men of Jabesh-Gilead in 2 Sam 2:5-7, where he also closely identifies himself with YHWH. In contrast to Abner, however, who seems to substitute his own action for that of YHWH and thus basically puts himself in the place of God, David adds his own action to that of YHWH and through his word choice shows that he recognizes that there is a difference between himself and YHWH. ${ }^{73}$ While Abner is primarily focused on himself and brashly wants to act for (or even instead of) YHWH, David is primarily focused on YHWH and humbly seeks to act like him. Thus, the difference between the two men once again becomes visible.

Abner's character is further revealed through the similarity of the opening line of his oath to the beginning of Jonathan's oath in 1 Sam 20:13, the only other place in 1-2 Samuel where someone uses his own name in an oath. Both Jonathan and Abner belong

\footnotetext{
${ }^{72}$ Though grammatically the oath formula is connected to what follows in vv. 9-10, i.e. Abner's act of making David king over all of Israel, the contextual connection to the immediately preceding rhetorical question at the end of v. 8 that deals with Abner's possible involvement with Rizpah should not be overlooked, in particular in light of the allusions in that question to other OT texts that speak about divine punishment, as noted above. Through his oath, Abner indirectly denies Ish-boshet the right to act as his judge in the matter of Rizpah and instead appeals to God as the final judge.

${ }^{73}$ See the analysis of 2 Sam 2:6 above.
} 
to the house of Saul, both swear that they will do good to David and both subsequently

seek to make a covenant with him. Only in Jonathan's case, however, is the reader

explicitly informed that the covenant was actually made. ${ }^{74}$ A comparison of the two

passages also shows that while Jonathan sides with David from the very beginning, when

it is still very much unclear whether or not David will actually become king, Abner only

does so when he seems to have no other choice. ${ }^{75}$ His loyalty to David seems to be based

primarily on opportunity, while Jonathan's is based on true friendship and love. Thus, the

allusion to 1 Sam 20 helps to evaluate Abner's action and to clarify his motives in 2 Sam

$3 .^{76}$

Verse 10

The content of the oath is revealed in 2 Sam 3:10, yet as Fokkelman observes, it

remains ambiguous who will be the active agent in bringing this about:

Is it Abner himself - in which case the subject of 9c is unchanged, and remains in operation - or is it God, who was the subject of $9 \mathrm{~b}$, and who is recognized by the speaker as the real policy maker? Are they both subject, inseparable? The rhetoric of the general is so subtle that it is no longer possible for the listener to detect where

\footnotetext{
${ }^{74}$ While Abner wants to make a covenant with David and David signals his willingness, there is no explicit indication in 2 Sam 3 that the two actually entered into a covenant agreement.

${ }^{75}$ Significantly, the contrast between Abner and Jonathan is already made explicit in 1 Sam 20:25 where Jonathan gets up from the table, while Abner remains sitting next to Saul. Thus the author indicates where the loyalties of the two men lie. Whereas Abner remains loyal to Saul, Jonathan distances himself from Saul by getting up from the table. Instead, he sides with David, whose place at the table is also empty.

${ }^{76}$ It is also insightful to compare Abner's oath with the only oath taken by David prior to 2 Sam 3. In 1 Sam 25:22 David invokes God to do to the enemies of David and so to add if David leaves of all that belongs to Nabal by morning anyone who urinates against the wall. Due to Abigail's unexpected peaceful intervention, David is unable to finish what he planned to do. He does not harm a single person belonging to Nabal and in turn the Lord strikes David's enemy Nabal so that he dies (1 Sam 25:37). Abner, on the other hand, invokes God to do to himself and so to add if Abner does not take the kingdom away from the house of Saul and raise up the throne of David over all of Israel and Judah. Due to Joab's unexpected violent intervention, Abner is unable to finish what he planned to do. He does not succeed in making David king over all of Israel and Judah and in turn ends up being killed himself. These similarities and differences once again highlight the superiority of David over Abner.
} 
divine initiative ends and human activity begins. With this brilliantly ambiguous move Abner has completed his strategy of religious self-legitimisation. The present lack of observable difference between God and Abner, does, however, turn against the speaker by lending itself to a psychological criticism of him: is it not true to say that Abner, through his fusing of divine authority and personal power politics, betrays his desire to be above both sides, exalted beyond criticism? Is there any appreciable difference between this and self-glorification ${ }^{77}$

Abner's desire to play God is further highlighted by the connection between v. 10 and 2 Sam 2:8 through the shared verb עָָבר in the hiphil form. Whereas in the earlier passage the verb is connected to Abner's efforts to make Ish-boshet king, in the later passage it is associated with Abner's efforts to take the kingship away from Ish-boshet. Fokkelman thus correctly concludes: "Abner is able to make and break a king at his own discretion"78 and appropriately asks: "is this not suspiciously very much akin to divine power?"79 It is indeed and once again brings to the fore the hubris of Abner that is so characteristic of him.

\section{Verse 11}

Abner's speech is met with a deafening silence, his profusion of words with no words at all as Ish-boshet is unable to offer any kind of a response. Once more he is not even afforded the honor of having his name mentioned and is thus reduced to a nameless and voiceless figure that is on the verge of disappearing from the narrative altogether. ${ }^{80}$ Indeed, he will not utter another word before his death in the following chapter. That he

\footnotetext{
${ }^{77}$ Fokkelman, Throne and City, 76-77.

${ }^{78}$ Fokkelman, Throne and City, 77.

${ }^{79}$ Fokkelman, Throne and City, 77.

${ }^{80}$ Fokkelman, Throne and City, 78: "We are forced to conclude that there is almost nothing left of this king."
} 
is presented as being unable/incapable (לאיץיכל) once again sets him in contrast to David, who is associated with the last six occurrences of the verb יכל יכ prior to 2 Sam 3. Four of them are found in 1 Sam 17 where David shows that he is able to fight against Goliath and kill him, while the other two occur in 1 Sam 26:25 where Saul says to David that he will "surely be able" (יכלי תתוּכל) who is able to accomplish what he sets out to do and demonstrates exceptional bravery in his dealings with Goliath and Saul, Ish-boshet is incapable even of responding to his own general because he is afraid of him. In a complete reversal of roles, he who seemed so courageous at the beginning of the scene now cowers in fear before his almighty general. It is a pitiful sight that not only "reveals the true nature of their relationship," ${ }^{82}$ but also strikingly highlights once again the weakness of both the king and his kingship.

\section{Verses 12-16}

Verse 12

That Abner is serious about what he has just announced becomes evident in the very next verse. Having effectively shut down Ish-boshet, he proceeds to make contact

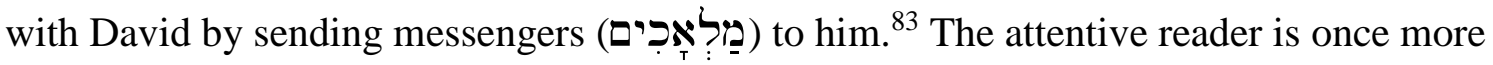

\footnotetext{
${ }^{81}$ Here the parallel between Goliath and Abner that was noted above once again comes into play. While David is able to respond to Goliath's speech that begins with the question "Am I a dog?" and bring him to justice, Ish-boshet is unable to respond to Abner's speech that begins with the question "Am I a dog's head?" and bring him to justice.

${ }^{82}$ Cartledge, $1 \& 2$ Samuel, 388.

${ }^{83}$ Interestingly, the author inserts the word Abner's behalf or, more literally, instead of him, raising the question why Abner did not go to David himself. A possible answer emerges once it is recognized that the same form of the term s. only occurs one other time in the Old Testament prior to 2 Sam 3:12, namely in 2 Sam 2:23 where Asahel falls and
} 
reminded of David's speech to the men of Jabesh-Gilead in the previous chapter since this was the last time messengers (מַלָאִָָים) were sent in the book of Samuel. A comparison of the two messages again reveals the contrast between David and Abner. While both men seem to have the same goal, namely win over the other side in order to unify Israel, their strategies are very different. As in his speech to Ish-boshet, Abner is primarily focused on himself and what he will accomplish for David. David's primary focus in 2 Sam 2, on the other hand, is on others, namely on the men of Jabesh Gilead and what they did for Saul and on YHWH and what David wishes him to do for the men of Jabesh Gilead. ${ }^{84}$ Furthermore, whereas Abner's goal is to convince David to make a covenant with him, David's primary interest seems to be the covenant between YHWH and the men of Jabesh-Gilead, as noted above. ${ }^{85}$ These differences once again emphasize Abner's pride and self-love, while at the same time reminding the reader that David is a suitable leader for Israel since he humbly recognizes the ultimate leadership of YHWH and genuinely cares for the well-being of the people.

dies "instead of him" (תָחתחז). The terminological connection between the two verses seems to suggest that Abner may very well have been afraid to meet with David because he had killed Asahel. Thus, the one who seemed invincible and was feared by Ish-boshet just one verse earlier may not be without fear himself. Fokkelman, on the other hand, translates the term as "on the spot" and argues that it occurs at this point to show that Abner contacted David while he was still in the presence of Ish-boshet (Fokkelman, Throne and City, 78).

${ }^{84}$ This contrast is further emphasized by the occurrence of the term $\boldsymbol{T}_{T}$ in both speeches. While Abner is focused on the strength of his own hand, David encourages the men of Jabesh-Gilead to strengthen their hands.

${ }^{85}$ Note also that while Abner's speech almost makes it appear as if David has no other choice but to make a covenant with Abner if he wants Israel to be united, David never puts any pressure on the men of Jabesh-Gilead to accept him as their king. 
As in his speech to Ish-boshet, Abner begins his message to David with a rhetorical question: To whom does the land belong? As scholars have noted, the question is ambiguous. ${ }^{86}$ Does Abner imply that the land is his and that David should therefore make a covenant with him or is the question an acknowledgement that the land is David's and that this is the reason Abner is seeking to make a covenant? While the characterization of Abner so far in the larger narrative as well as the fact that, based on 2 Sam 2:9, Ish-boshet controlled more territory than David make the former interpretation seem more plausible, from a literary perspective the ambiguity of the question may be precisely the point, as it aptly reflects the state of affairs and serves as a poignant reminder of the division that still exists in the land ${ }^{87}$ Yet as Abner's words indicate, this division may now come to an end if David is willing to make his covenant with Abner, for then Abner will ensure that all Israel will turn to David. It is a tempting offer, for it would enable David to unify Israel peacefully. However, the offer is also not unproblematic, for it suggests that David cannot become king over a united Israel without the help of Abner, thus making the king dependent on the general. Abner would once again be the "king-maker," raising the question what kind of power and influence Abner would have in a united kingdom and whether David would end up like Ish-boshet - a puppet king at the mercy of his own general. $79-80$.

${ }^{86}$ Cartledge, 1 \& 2 Samuel, 389; Youngblood, “1 \& 2 Samuel,” 834; Fokkelman, Throne and City,

${ }^{87}$ Smith, A Critical and Exegetical Commentary, 360. 
Verse 13

That this will not be the case becomes evident immediately. Though the fact that David is also not mentioned by name at the beginning of v. 13 might initially suggest otherwise, his answer to Abner clearly demonstrates that he is not like Ish-boshet. Though he reacts favorably to Abner's request, his answer makes it clear that he is the one in charge and that an agreement can only be reached on his terms. To begin with, he responds to Abner's "make your covenant with me" with an emphatic "I, I will make (אַנִי אִכְרָת) a covenant with you," reaffirming that it is David who will make a covenant with Abner, not the other way around. This positive response is immediately qualified,

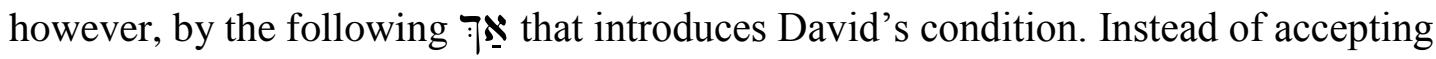
Abner's offer to do something great for him, namely turn all Israel to him, or presenting him with a whole list of conditions, David asks him to do only one thing that at first glance appears to be quite simple: bring Michal with him when he comes to David. What might initially seem like a minor detail that could be taken care of easily enough, is, however, in reality a very major request designed to test how powerful Abner really is, how serious his intentions are and whether he is willing to accept David as the legitimate successor of Saul. Michal, after all, as David himself notes, is "Saul's daughter" (שישאוּל

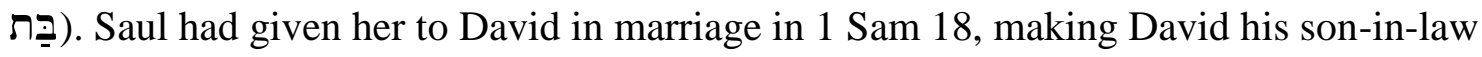
and thereby a potential successor to the throne, but had later given her to a man named Palti when David fled for his life, thus officially severing David's connection to the house of Saul (see 1 Sam 25:44). Returning her to David is therefore a highly significant act, for through the reunion with Michal David would be "legally repositioning himself 
back into the house of Saul" and thus "legitimizing his claim of being qualified to rule over territories once ruled by Saul. ${ }^{188}$ Furthermore, the fact that the bringing of Michal in the third clause of David's response is in the parallel position to the turning of all Israel in the third clause of Abner's offer to David suggests that "Michal's coming represents and symbolizes the coming of Israel." ${ }^{89}$ Hence, the return of Michal "symbolically... signified the gift of the kingdom." 90

David's condition to Abner is also significant in light of the previous scene. There Ish-boshet accused Abner of sleeping with Saul's concubine Rizpah, the daughter of Aiah, a highly significant act that was tantamount to claiming the throne and symbolized the removal of the kingship from Ish-boshet. Though Ish-boshet seeks to bring Abner to justice for this alleged taking of a woman from him, he is in the end reduced to silence,

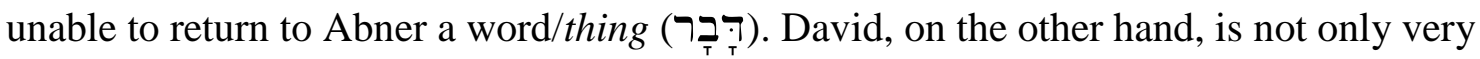
capable of answering Abner but also requires one thing (דָָר ) from him so that justice may be restored. He is to bring a woman to him, namely Michal, the daughter of Saul, a highly significant act that was tantamount to claiming the throne and symbolized the gift of the kingdom for David. He who was accused of taking a woman to demonstrate his own power must now demonstrate that power by taking another woman, yet in the very act of taking and bringing that woman he will be demonstrating the power of another.

\footnotetext{
${ }^{88}$ Bergen, 1,2 Samuel, 309.

${ }^{89}$ Fokkelman, Throne and City, 82.

${ }^{90}$ Leithart, A Son to Me, 190.
} 
Abner has thus found his match in David. In this way the superiority of David over both Ish-boshet and Abner is once again clearly demonstrated. ${ }^{91}$

\section{Verse 14}

Abner's reaction to David's demand is not recorded. Does his silence indicate compliance or unwillingness? Whatever the case may be, David will not leave this matter up to the general. Like Abner, he sends messengers - not to the general, but to Ish-boshet and demands that Michal be returned to him. The fact that David contacts Ish-boshet is significant for at least two reasons. First, it shows that David follows proper protocol. The return of Michal, which symbolizes the gift of the kingdom, is not to be accomplished secretly by Abner but openly and officially by Ish-boshet, since he is not only the official king but also, as the son of Saul (as he is designated precisely in v. 14!), "the representative of the family of Saul who has the most legal liability regarding Michal." ${ }^{92}$ It was Saul who had wrongfully taken Michal away from David, but Saul is dead. Therefore, David asks Saul's heir to reverse the injustice done to him. ${ }^{93}$ Second, David's move undermines Abner's claim to power and at the same time puts it to the test. While the general seeks to present himself as the de facto king and lord of the land who will magnanimously transfer his kingdom to David, David's message to Ish-boshet transfers the responsibility for the return of Michal from Abner to Ish-boshet, giving the

\footnotetext{
${ }^{91}$ Note also that while Abner is accused of unlawfully taking a woman, David's taking of Michal is lawful, since she was his wife and he had not divorced her.

${ }^{92}$ Fokkelman, Throne and City, 83. Note that v. 14 is the only time in 2 Sam 3 that Ish-boshet is expressly designated as the son of Saul.

${ }^{93}$ Smith, A Critical and Exegetical Commentary, 361.
} 
official king instead of the general the final say in the matter. In this way, David not only sends a clear message to Abner concerning his importance but is also able to ascertain the strength and determination of both Ish-boshet and Abner. A favorable response on Ishboshet's part would not only be a confession of his weakness but also allow Abner at best to act in accordance with and obedience to his king, thus putting him back in his proper place as Ish-boshet's subordinate. If Ish-boshet refuses, on the other hand, Abner would have to prove his power by bringing Michal against the wish of his king, which in turn would force Ish-boshet to show his true colors. Contacting Ish-boshet is therefore a clever move on David's part through which he is able to stay in control of the situation and gain valuable insights into the power structure of Ish-boshet's kingship.

David's strength and superiority also become evident in the message itself which is straightforward and to the point. Michal is to be given to David. In contrast to his

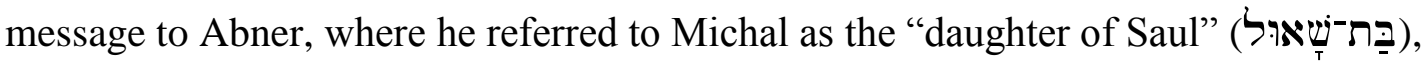

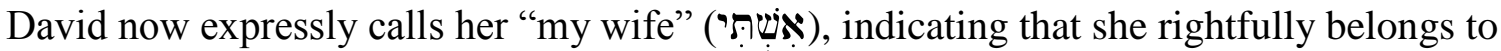
him. This information presents another indirect blow to Abner's ambition, for it means that the only thing which David asks Abner to bring to him is something which already belongs to David anyways. ${ }^{94}$ As David reminds Ish-boshet, Michal belongs to him because he betrothed her to himself for a hundred foreskins of the Philistines. This reference back to 1 Sam 18 once more underscores David's exceptional strength and bravery (in connection with a woman) which stands in striking contrast to Ish-boshet's

\footnotetext{
${ }^{94}$ Hertzberg, I \& II Samuel, 259.
} 
lack of courage (in connection with a woman) in the preceding scene in 2 Sam $3 .{ }^{95}$ It also shows that David is more than capable of fulfilling a condition set by another as a prerequisite for entering into a covenant relationship - a feat that Abner still needs to prove he is able to do as well. Hence, the message once again highlights David's superiority over Abner and Ish-boshet.

Verses $15-16$

Not surprisingly, Ish-boshet does not object, but dutifully proceeds to fulfill David's wish. ${ }^{96}$ Like Abner and David he also sends, yet in contrast to the first two

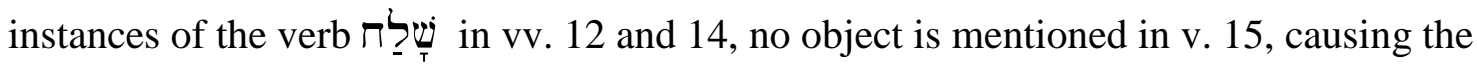
reader to wonder who was actually sent. The answer is delayed until the very end of v. 16 where Abner all of a sudden reappears. Apparently, it was he who was sent by Ish-boshet, yet the author does not consider it necessary to mention this in v. 15, thus further reducing the significance of Abner's role in the process of Michal's return. On top of being unable to bring Michal of his own will, but instead being forced to do so on orders of Ish-boshet, he is not even afforded the honor of being mentioned by name as Ishboshet's agent who ensures that Michal is indeed returned. When he does at last appear

\footnotetext{
${ }^{95}$ The issue of strength is also highlighted through the mention of foreskins, as Fokkelman notes: "Via the concrete entity of the foreskins we arrive at the topic of potency, and the subject of marriage touches on this as well. David's might yields him a bond with the king's daughter, Saul's demand creates warfare which fails to turn against David but provides him instead with a new opportunity of demonstrating his strength, and the bond itself is a token of strength." (Fokkelman, Throne and City, 84)

${ }^{96}$ Note once again the contrast to David that is also emphasized by the structure of vv. 12-16: When Abner sends messengers to David (A), David responds favorably but through his response makes it clear that he is in charge and that an agreement can only be reached on his terms (B). When David sends messengers to Ish-boshet (A'), Ish-boshet simply does what David wants without a word of protest (B'), even though he would have had much more reason to do so than David in v. 13.
} 
on the scene it is not as the triumphant king-maker he intended to be, but as the obviously exasperated escort of Michal and her weeping husband whom he finally commands to return home. Thus he who at the beginning of the scene so confidently presented himself to David as the real ruler of Ish-boshet's kingship and hence the decisive agent in making David king over all Israel, just a few verses later has been reduced to an insignificant servant who must endure the embarrassment of escorting a wife who is followed by her weeping husband. ${ }^{97}$ The fact that this transformation is the result of what David said and did in vv. 13 and 14 is just one more indicator of the strength and superiority of the king of Judah.

Yet in spite of all the evidence of David's strength and superiority over Abner and Ish-boshet in this scene, Leithart correctly notes that "the story is told in such a way as to highlight Paltiel's sorrow at losing Michal." 98 The love and affection Paltiel apparently had for Michal contrasts strikingly with the dispassionate attitude of David for whom Michal seems to be little more than "a pawn in a larger complex of political maneuvering." $" 99$ The contrast does not reflect positively on David and suggests that his course of action in this scene is less than ideal. A careful reading of vv. 12-16 provides further evidence in support of this view.

${ }^{97}$ Fokkelman, Throne and City, 86. In this way Abner is confronted with "a very real and emotional consequence of his own decision and disloyalty." (Ibid.) The whole scene on the road also vividly illustrates what is happening in the larger narrative. Like Ish-boshet, the son of Saul, the man (שיָ) Paltiel, the son of Laish, has a woman taken from him. Though both men refuse to simply accept this taking, they are in the end powerless to stop it, but instead submit to Abner, unable to answer him a word.

${ }^{98}$ Leithart, A Son to Me, 191.

${ }^{99}$ Birch, "First and Second Books of Samuel," 1224. While 1 Sam 18:20 states that Michal loved David, David is never said to have loved Michal. 
To begin with, the correct answer to Abner's opening question in v. 12: "To whom does the land belong?" is neither "David" nor "Abner," but "YHWH." land belongs to him, he is the only one who can give it. As the story of both the patriarchs and Israel in the Pentateuch shows, the land is given on the basis of a covenant relationship with YHWH. ${ }^{101}$ Given that David seems to be recapitulating that very story, as suggested above, he should not have sought to make a covenant with the "pseudo-god" Abner, but focused on the covenant with the one who is the only true God as he had done in his message to the men of Jabesh-Gilead in 2 Sam 2. ${ }^{102}$ Instead of asking (שָׁאל

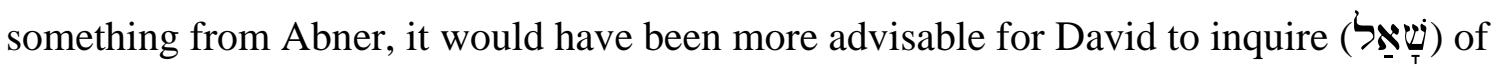
YHWH, as he had done in the past and most recently in 2 Sam 2:1, the last time the term

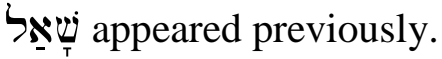

The result of this last inquiry was that David received the land as well as the kingship over Judah, as the people took the initiative to make him king. Then he sent a message of blessing to the men of Jabesh-Gilead, demonstrating his genuine interest in their welfare as well as his desire for them to remain in a covenant relationship with YHWH and fight his battles to finish the conquest. In addition, he did not demand their loyalty but gave them the free choice to accept him as king. In the present scene in 2 Sam 3, however, David sends messengers to demand that Michal, who represents the kingdom

\footnotetext{
${ }^{100}$ See e.g. Lev 25:23. Ultimately, the divine ownership of the land is based on Gen 1 where God is presented as the creator of heaven and earth.

${ }^{101}$ See e.g. Gen 17:7-8; 26:3-4; 28:13-14; Exod 6:4; 34:10-11.

${ }^{102}$ As noted above, a number of terms in 2 Sam 3:12-13 allude precisely to this message in 2 Sam 2:5-7. 
and the people, as suggested above, be given to him. While it may have been his right to make such a demand, no love or concern for the welfare of the other is involved and no free choice is given. Instead, Michal is reduced to an object whose sole purpose is to demonstrate David's power and his right to the kingship over all Israel. ${ }^{103}$ Thus David is in danger of violating a basic principle of his kingship, namely that he will not take this kingship by force.

At this point the allusion to 1 Sam 18 in v. 14 is instructive, since that chapter emphasizes that not only Michal but also Jonathan as well as all of Israel and Judah loved David. This love was not coerced but freely given to David because he had success in everything he did and this success resulted from the fact that YHWH was with him. ${ }^{104}$ In contrast to 2 Sam 3 Michal was not simply given to him, but he had earned the right to marry her by fighting against Israel's enemies. This concern for finishing the conquest coupled with a close relationship with YHWH (both of which are key components of David's kingship, as shown above) seems to be precisely what is missing in 2 Sam 3. Instead of trusting YHWH, being actively engaged in completing the conquest and in this way earning the love and support of the people, David settles down in Hebron and begins to trust in himself and his own strength, as he marries multiple women, at least one of

\footnotetext{
${ }^{103}$ David's course of action is also problematic because the return of Michal suggests that David is the rightful successor of Saul as king over Israel because he is part of Saul's family. Significantly, the transfer of Michal is never completed within the narrative, but ends at Bahurim, which Fokkelman in this context reads as "election" (Fokkelman, Throne and City, 85), reminding the attentive reader that it is not David's relationship to Saul but rather his divine election which qualifies him to be Saul's legitimate successor. (See also Bodner, David Observed, 51) At the same time, since Michal represents the kingdom, the fact that there is no report of Abner bringing her to David as requested already hints at what will become evident shortly, namely Abner's inability to transfer the kingdom to David.

${ }^{104}$ See 1 Sam 18:1, 3, 5, 12, 14-16, 20, 28, 30.
} 
which is the daughter of a Canaanite king, and seeks to demonstrate his superiority over the house of Saul through an act that symbolizes his taking of both kingdom and people

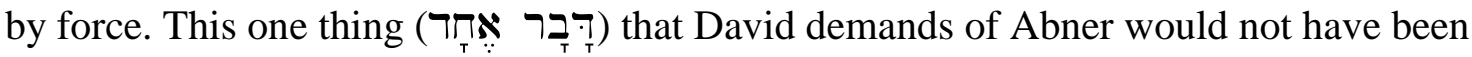
necessary if David had faithfully fought against Israel's enemies and humbly trusted YHWH to give him both land and people, for like Israel at the time of the conquest he

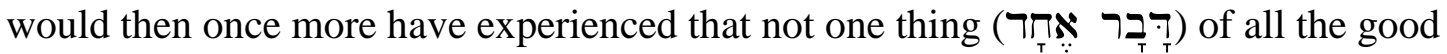
things which YHWH had spoken to him had failed (Josh 23:14). ${ }^{105}$

However, instead of trusting YHWH and acting like him as he had sought to do in his dealings with the men of Jabesh-Gilead, David's course of action in this scene is reminiscent of that of the "pseudo-god" Abner throughout the narrative up to this point. The similarity between the two men that was already hinted at through the structural arrangement of the previous literary unit now becomes more clearly visible as both send messengers and both take a woman from Ish-boshet in order to demonstrate their power over him. ${ }^{106}$ In addition, just like Abner back in 2 Sam 2, David seeks to take the kingship by force without any concern for the people. Thus, he is fast on his way to become like Abner.

\footnotetext{
${ }^{105}$ Intruigingly, Josh 23:14 is the only previous place in the Old Testament where the expression

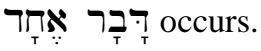

${ }^{106}$ Note also David's emphatic אָָנִ in v. 13 which reminds of Abner's use of this same pronoun in v. 8. The focus of the speeches of both men is on what they have done/will do. 


\section{Verses 17-19}

\section{Verse 17}

No sooner has Paltiel turned back at the end of v. 16 than the story follows suit. Instead of providing further information regarding Michal's return, as the reader might expect, the narrative abruptly shifts to what is viewed as a flashback by many commentators. ${ }^{107}$ From Bahurim ("young men's village") the account moves to Abner's communication with the elders of Israel. The word of Abner which was against Paltiel is now said to be with the elders. With the command to Paltiel, Abner has thus once more taken control of things within the narrative. This is confirmed in the following verses. Seven times his name is mentioned in vv. 17-21, five times in the subject position. His power and authority as well as his hubris also become evident once again through the

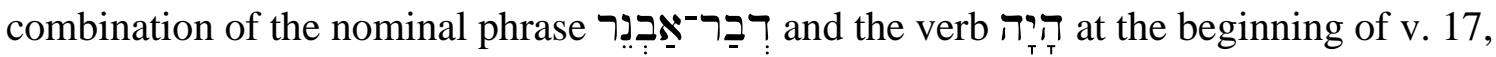
since this construction otherwise is used for the word of YHWH coming to someone. ${ }^{108}$ The wording thus suggests that Abner is playing God again, seeking to deliver the kingdom to David.

In order to achieve this objective Abner first addresses the elders of Israel, the most important and influential group of leaders and representatives of the people in the land. The last time this group appeared was in 1 Sam 8, where the elders asked Samuel for a king. Now Abner asks for their support in making David the successor of that first king. His speech to them consists of three parts. He begins by reminding them that they

\footnotetext{
${ }^{107}$ See e.g. Fokkelman, Throne and City, 86; Anderson, 2 Samuel, 59; Smith, A Critical and Exegetical Commentary, 362; Youngblood, “1 \& 2 Samuel,” 835.

${ }^{108}$ Fokkelman, Throne and City, 87. See e.g. 2 Sam 24:11; 1 Ki 16:7; Eze 24:20.
} 
had desired to have David as their king in the past. From a psychological point of view this is a smart move, for Abner's words suggest that he is only inviting the elders to act on what they had always wanted to do anyways. At the same time, however, these opening words of Abner's speech are also quite revealing, for they further confirm the impression that Ish-boshet's kingship was solely Abner's project that was forced on the people against their will. Yet all of this does not matter anymore now. Like Paltiel, Abner has changed direction and now in turn encourages the elders to return to their former position of wanting David as their king.

\section{Verse 18}

Abner then proceeds to issue an emphatic call for action. Now is the time for the

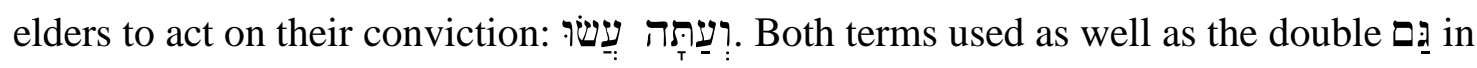
v. 17 once again remind of David's message to the men of Jabesh-Gilead in 2 Sam 2:5-7, inviting the reader to compare the two passages. While Abner begins his message with a statement that suggests that the elders in the past did not act on their conviction with regard to his enemy David (most likely because Abner prevented them from doing so), David begins by commending the men of Jabesh-Gilead for in the past acting on their conviction with regard to his enemy Saul. While both David and Abner encourage the other party to act, David's call to action is preceded by a word of blessing, a wish for

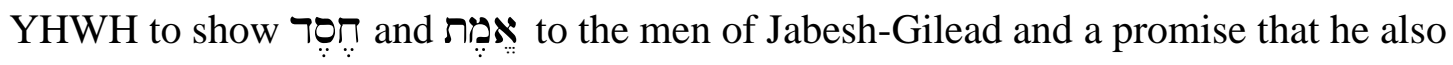
would do good to them, elements that are completely absent from Abner's message. Whereas David's call to action thus occurs in a context of doing good to one another and is primarily given to further the interests of $\mathrm{YHWH}$ as shown above, Abner only seems to 
call the elders to act because it suits his own interests. These differences highlight the contrast not only between the courageous men of Jabesh-Gilead and the apparently cowardly elders of Israel but also once again between David, who seeks to base his kingship on unselfish concern for others and $\mathrm{YHWH}$ as well as freedom of choice, and Abner, who only appears to be concerned about others and YHWH, but in reality is motivated solely by his own selfish desires.

In order to further motivate the elders to become active in the way he wants them to, Abner concludes his message by quoting a word of YHWH concerning David which emphasizes David's election as the one through whom YHWH will save Israel from all their enemies, including the Philistines. In this way Abner is able to present his plan, "not as the wisest political course of action, but as the will of Yahweh." ${ }^{109}$ Just as in his earlier speech to Ish-boshet Abner thus once more "makes God dance to the tune of his power politics." 110 Yet in doing so, he ironically not only admits the failure of his whole Ishboshet project but also reveals again that he was aware of the divine will all along, meaning that he willfully rejected that will when he made Ish-boshet king. That rebellion against YHWH is never addressed, however, either by Abner or by the elders. ${ }^{111}$ What happened in the past is unimportant. All that matters now is that the divine will suits Abner's own interests at this particular moment in time.

${ }^{109}$ Smith, A Critical and Exegetical Commentary, 362.

${ }^{110}$ Fokkelman, Throne and City, 89.

${ }^{111}$ This is especially significant in light of the fact that the elders of Israel had been entrusted with the law and served as judges (Deut 31:9). 
The divine oracle Abner quotes is also significant because it reaffirms what was already suggested by a close reading of the previous scene. Neither Abner nor David is ultimately in charge of affairs, but YHWH. David is his servant and Israel his people whom he wants to save from all their enemies through David. Rather than settling down at Hebron and seeking to make himself king by political maneuvering and force, David should therefore seek to do the will of his Lord and serve the people of his Lord by finishing the conquest. In the midst of all the about-turns in the narrative, the divine oracle is thus a timely reminder that David also must change direction so that the fortune of Israel may be turned around.

Verse 19

Interestingly, the reaction of the elders to Abner's words is not recorded. Instead, the focus of the narrative remains on the very active Abner who now proceeds to speak to another important group whose support he needs to make David king over all Israel, namely Abner's own tribe Benjamin. While Abner's words to the elders may have been

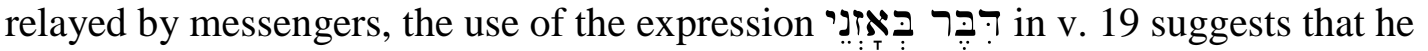
personally speaks with the Benjaminites. ${ }^{112}$ This is not surprising, given that Benjamin is the tribe of the house of Saul and therefore the group that is probably most hesitant about (if not opposed to) Abner's plan, but whose cooperation is crucial in order for that plan to succeed. ${ }^{113}$ Hence, a personal audience is necessary, if Abner is to have any chance of convincing them to support his cause.

\footnotetext{
${ }^{112}$ McCarter, II Samuel, 116.

${ }^{113}$ McCarter, II Samuel, 116.
} 
Though again no response is reported, Abner's negotiations with Benjamin are apparently sufficiently successful for him to now meet with David at Hebron. While everything thus seems to be moving along nicely in the way Abner intended, a close reading once again suggests that the situation is not as ideal as it appears to be. A first hint is already found in the very fact that Abner must speak separately with Benjamin and that the house of Benjamin is again mentioned separately from Israel at the end of v. 19. While the mention of Hebron as well as the double occurrence of the term same verse suggest unity and remind of the unification that would result from the transfer of Ish-boshet's kingdom to David, the double separation of Benjamin from the rest of Israel causes the attentive reader to wonder how united the kingdom that is to be transferred truly is and whether real unity under David is even possible under these circumstances.

Complicating matters further is the conspicuous passivity of both the elders and Benjamin in vv. 17-19 that stands in striking contrast to the tireless activity of Abner, suggesting that the transfer of the kingdom is still primarily his project. While Abner's position is clear that of the elders and Benjamin remains in the dark. How do they feel about what Abner is proposing? Are they in agreement or not? We are not told. The uncertainty regarding their position is heightened even further by the ambiguous statement in v. 19 that Abner goes to speak to David everything that is good in the eyes

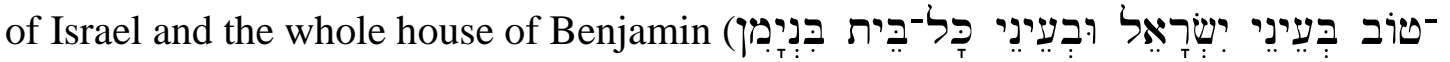

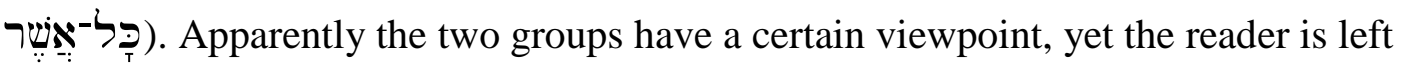


wondering what exactly this viewpoint is. ${ }^{114}$ It almost appears as if both groups will not simply accept David as their king, but are here through Abner presenting the conditions on which they will do so. ${ }^{115}$ Ever so subtly the people seemingly have taken control of the situation.

It is worth noting at this point that the somewhat hesitant and calculating attitude toward David on the part of the people presents yet another significant contrast to $1 \mathrm{Sam}$ 18 where David was loved by all of Israel and Judah (v. 16) and where it was good in the

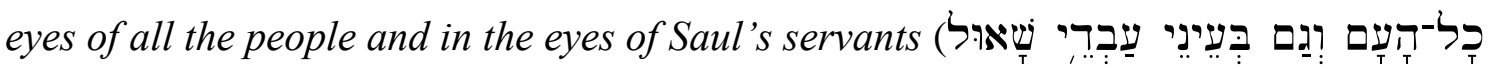

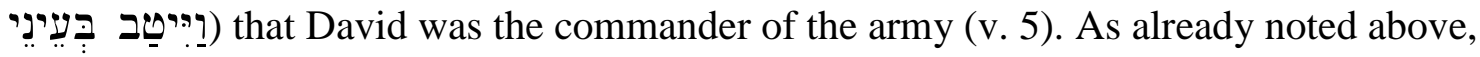
the reason why everyone loved and accepted David, was because he had success in fighting against Israel's enemies because YHWH was with him. Just as in 2 Sam 3:14, the terminological parallel to 1 Sam 18 in v. 19 thus suggests that instead of abruptly forcing the transfer of the kingdom with the help of Abner, the better option for David would have been to earn the trust and support of the people by faithfully fighting against Israel's enemies with the help of YHWH. ${ }^{116}$

\footnotetext{
${ }^{114}$ Fokkelman, Throne and City, 90.

${ }^{115}$ McCarter, II Samuel, 117.

116 This is further confirmed by the verbal link in v. $19 \mathrm{~b}$ to the meeting between Abigail and David in 1 Sam 25, which was the last time someone spoke "in the ears" of David previously. Like Abner, Abigail comes to David with an entourage and calls him אִ אִרני yet in contrast to the general, who not once offers an apology to anyone for the wrongs he committed, she humbly falls at David's feet and takes the blame for what her husband did upon herself (1 Sam 25:23-24). Furthermore, while Abner constantly emphasizes the role he will play in making David king over all Israel and David is in danger of taking the kingdom by force, Abigail reminds David of the danger of helping himself with his own hand and assures him that YHWH will make him an enduring house, because he fights the battles of the Lord (1 Sam 25:26, 28)!
} 


\section{Verses 20-21}

Verse 20

Having spoken to the elders and Benjamin, Abner at last arrives at Hebron. ${ }^{117}$ As expected, he does not come alone, yet it is not the woman Michal, without whom he was not to see David's face, who accompanies him, but twenty men. Instead of bringing Saul's daughter, who represents the kingdom, Abner arrives with a group of men whose number ominously reminds of the battle at Gibeon in the previous chapter and the losses sustained there by David's forces, including Asahel's death at the hands of Abner. ${ }^{118}$ Thus the suspense is increased even more: in light of the former hostility between the two sides and the role Abner played in the conflict, how will the general and his entourage be received as they enter Hebron for the first time since that fateful day at Gibeon? Will David indeed make a covenant with Abner or was the whole thing a big bluff by David designed to get Abner to Hebron so that David can finally exact revenge? Though such a reaction would have been understandable in light of Abner's past dealings with David, revenge seems to be the last thing on David's mind. Instead of retaliating or at least

\footnotetext{
${ }^{117}$ Note that the verb that is used here (בוא) is the same one that occurs in Ish-boshet's question to Abner in v. 7. As Abner and his men enter Hebron to finalize the transfer of the kingdom to David, the issue of unfaithfulness and treason is thus brought to mind again, including the important question regarding the underlying motives ("why did you go in...?"). Indeed, this very question ("why did you do this?") is the central question of the whole narrative.

${ }^{118}$ Note that, according to 2 Sam 2:30, at the end of the battle "there were missing of David's servants nineteen men and Asahel."
} 
receiving the delegation coolly, David makes a feast for Abner and his men, welcoming them as his honored guests. ${ }^{119}$

Verse 21

What follows in v. 21 is what will turn out to be the last speech of Abner's life, in which he addresses the final thing that is needed for the transfer of the kingdom to become reality: a covenant between all Israel and David. As the rapid sequence of three first person singular verbs at the beginning of the speech demonstrates, Abner once again intends to play a key role in this process: he will arise, he will go and he will gather all Israel to David. At the same time, however, his language has become much more deferential compared to v. 12 or his exchange with Ish-boshet at the beginning of the narrative. For the first time he calls David "my lord" and recognizes him as "the king." The once so antagonistic Abner, who opposed David where he could, has by all appearances become a devoted servant of David, seeking only his very best, and is sent away in peace to complete his mission. The war that the narrative began with has been replaced with peace. ${ }^{120}$ Hence, as Abner leaves Hebron

"everything is in place for David to assume the governance of Saul's territory. We expect that the next scene will present David's coronation by the elders of Israel and the Benjaminites. But those festivities are about to be delayed. Enter Joab."121

${ }^{119}$ As Fokkelman notes, David and the feast surround Abner and his men in the Hebrew text of 2 Sam 3:20, emphasizing how "David's courtly care surrounds the group" (Fokkelman, Throne and City, 91). This arrangement contrasts nicely with that in the first half of the verse where Abner and his twenty men surround David at Hebron.

${ }^{120}$ Fokkelman, Throne and City, 93.

${ }^{121}$ Morrison, 2 Samuel, 53. 


\section{Verses 22-27}

Verse 22

"Make your covenant with me, and behold (הִגנה), my hand shall be with you and I will cause all Israel to turn to you," Abner had said to David in v. 12. Now he has departed to do just that. Yet when the reader is bidden to "behold" (הפחה) in v. 22, it is not Abner and all Israel who come to Hebron, but David's servants and Joab. From the defective Abner, who used to oppose David, but just a moment ago professed to be his servant, the narrative thus moves to those who have faithfully served David throughout his time at Hebron. With all the focus on Abner, Benjamin, and Israel, the reader (and David?) had almost forgotten about these loyal supporters, who significantly last appeared at the end of 2 Sam 2. Just when it seems that peace has become a very real possibility, the appearance of these protagonists thus ominously brings back to mind once more the battle at Gibeon and in particular the unresolved conflict between Joab and Abner (in which the death of Asahel plays a significant role), causing the reader to wonder how those who support David feel about his negotiations with Abner and how this will affect the whole unification project. David may be willing to unite the nation with the help of the opportunistic Abner, but what about his loyal servants, who lost twenty of their comrades on the battlefield at Gibeon? David may have welcomed Abner but what about Joab? Is he willing to make peace with the one who killed his brother? Or is he out for revenge? Though these questions remain unanswered for the moment, a slight hint is nevertheless already provided by the contrast between the first and second half of v. 22. While those returning to Hebron with Joab from a most likely violent clash 


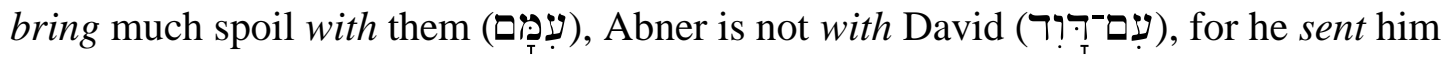
away in peace. At least from Joab's perspective, as will become more clearly evident shortly, the prey has escaped.

In striking contrast to Abner and his delegation, those who return to Hebron in vv. 22-23 do not receive any kind of special welcome from the king or the people. While the

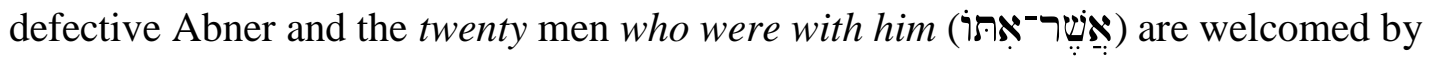
David with a feast, even though Abner apparently fails to bring Michal with him, the

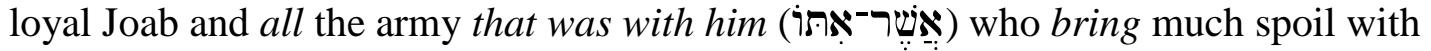
them do not appear to receive any special attention upon their return. ${ }^{122}$ Their spoil, it seems, is not as important as the spoil which Abner promises to bring, but has failed to secure up to this point. In a subtle way, the author thus once again seems to suggest that David's own interests supersede his concern for the people.

Verse 23

The only welcome Joab does receive is a report about Abner's visit to Hebron in

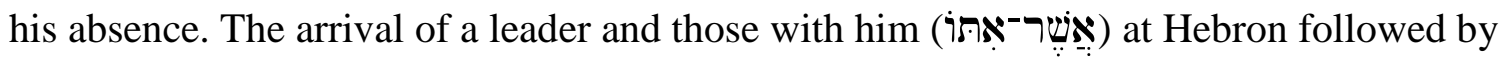
a report once again reminds of the beginning of 2 Sam 2 where David and those with him

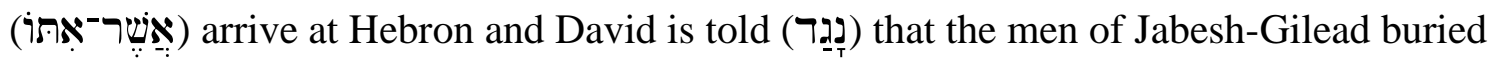
Saul (vv. 3-4). ${ }^{123}$ Instead of criticizing or even punishing them, as one might expect,

\footnotetext{
${ }^{122}$ It does not appear coincidental that v. 13 ("unless you bring") and v. 22 ("and they brought") are the only places in 2 Sam 3 where the hiphil of בוא occurs.

${ }^{123}$ Both 2 Sam 2:4 and 3:23 have the hiphil imperfect 3rd masculine singular of נגר, the only occurrences of this form in 2 Sam 2:1-5:5. Brueggemann notes the significance of the form in v. 23 with 218
} 


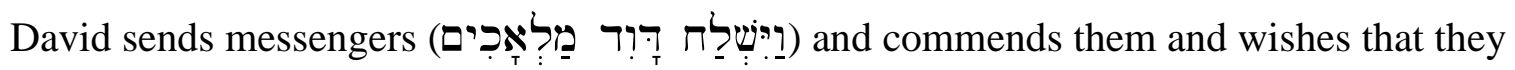

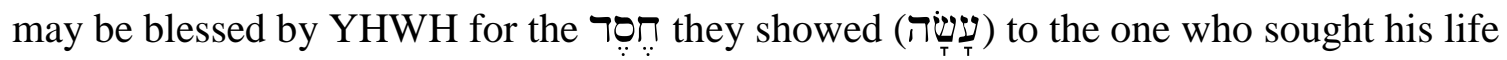

for many years. Joab, on the other hand, sharply criticizes David for what he did (עָ עִ

regarding the one who killed Joab's brother in battle (v. 24) and then retaliates by sending

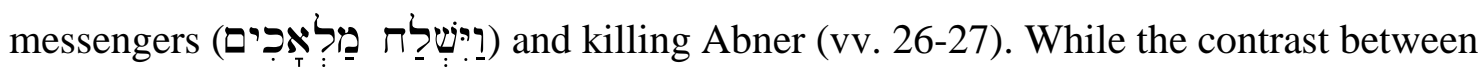

David and Joab reflects negatively on the latter and reaffirms that he is not like David, the comparison between David and the men of Jabesh-Gilead also once more reveals the less than ideal nature of David's course of action, for unlike those who buried Saul, David does not appear to be motivated by unselfish חֶֶ? in his dealings with Abner. Thus, the parallels to the opening verses of 2 Sam 2 remind the attentive reader of a foundational principle of David's kingship and show that both Joab (in a quite obvious way) and David (in a more subtle way) have departed from this principle.

Verse 24

Interestingly, those who speak to Joab do not mention the purpose of Abner's visit, but instead emphasize what has already been stated twice before, namely that David sent Abner away in peace. ${ }^{124}$ Whether they do not know the exact purpose or purposefully do not mention it is not clear, but if they had hoped to arouse Joab's anger,

regard to the issue of culpability for Abner's death: "The narrator is cunning in his use of a verb without an antecedent. What operated, according to the narrative, was court gossip. No one can be identified who informed Joab. No one can be held accountable. No one but Joab was identified. The lack of other subjects in the grammar isolates Joab even more as the one who is singularly held responsible for this dread act of murder that is to follow." (Brueggemann, First and Second Samuel, 228)

${ }^{124}$ The three-fold repetition of this phrase in vv. 21-23 stands in striking contrast to the war and violence that Joab is associated with in these verses. 
they are not disappointed. Like Abner just a few verses before, Joab comes to David, but he does not speak like a servant to his king as the older general had done. ${ }^{125}$ Instead, the scene is reminiscent of the exchange between Ish-boshet and Abner at the beginning of the narrative, where Abner shows a similar lack of respect for his king. ${ }^{126}$ The parallel does not flatter Joab, for it further confirms what already became apparent in 2 Sam 2:1232, namely that at his core he is quite similar to the one he accuses before David. Like Abner, he is easily upset and selfishly seeks to blame others, showing no respect towards his superior in the process. This attitude once again sets both men apart from David who always dealt respectfully with his lord Saul, even when the latter unjustly (!) sought to kill him, and was willing to acknowledge his mistake when he sought to retaliate against Saul's alter ego Nabal in 1 Sam $25 .^{127}$

No sooner has Joab appeared before the king than he launches into an impassioned speech consisting of two parts of three lines each that exhibit a chiastic structure and revolve around the central assertion in v. 25 a that David knows Abner. ${ }^{128}$ In the first part of the speech (v. 24) Joab accuses David, in the second (v. 25) Abner. His

\footnotetext{
${ }^{125}$ Note that v. 24 does not state that Joab came to David but that he came to the king, emphasizing among other things David's position and authority as well as Joab's lack of respect.

${ }^{126}$ Fokkelman, Throne and City, 101. Hertzberg, I \& II Samuel, 261, comments: "The reader can only be amazed at the general way in which the commanders talk to their kings."

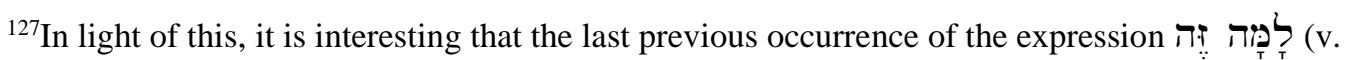
24) was in 1 Sam 26:18 where David asks Saul why (לְ⿱ speech David refers to Saul three times as "my lord" and twice as "king," while calling himself Saul's "servant." Though he could very well have accused Saul in the same way Joab did ("What have you done?), David never directly accuses Saul at all but instead begins his speech with a "why" question (cf. Joab who begins with an accusation and only then asks the "why" question, giving this question a completely different tone) and then asks "What have $I$ done?". follows:

${ }^{128}$ Fokkelman, Throne and City, 99 . The chiastic structure of the speech may be diagrammed as
} 
opening rhetorical question "What have you done?" is highly ironic in light of what will transpire just three verses later. ${ }^{129}$ In many ways, it functions as a summary of the entire narrative, appropriately reflecting the unbelievable horror of Joab's upcoming murder of an Israelite brother, while at the same time reminding the attentive reader of both Abner's and David's less than ideal course of action in the story so far. For Joab, however, it applies specifically to the information he received in v. 23, which he now repeats, framing the second part as another accusing question and ominously substituting the final

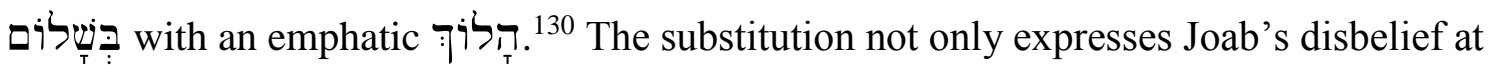
the fact that David did not detain Abner ("he is really gone?") but also suggests that he "sees Abner's departure as an escape from justice"131 ("he went, going off," i.e. "he got away" as the NRSV renders it). Thus, Joab presents himself as David's judge and at the same time indirectly calls into question David's ability to act as a competent judge who renders just judgments.

Verse 25

Without waiting for an answer to his question, Joab moves on to the second part of his speech. Instead of giving David a chance to explain to him why he let Abner depart

A What have you done? (24a)

B Abner's coming and going - why did you let him go? (24b)

$X$ You know Abner, the son of Ner (25a)

B' David's coming and going - Abner is a spy (25b)

$\mathrm{A}^{\prime}$ To know all that you are doing. (25c)

${ }^{129}$ Vom Orde, Das zweite Buch Samuel, 62.

${ }^{130}$ As Alter notes, the expression Joab uses to describe Abner's departure "sometimes occurs in the Bible as a euphemism for dying (see Job 27:21 and Jeremiah 22:10)." (Alter, The David Story, 212)

${ }^{131}$ Morrison, 2 Samuel, 54. 
in peace, Joab now explains to David why he should not have done so. He claims to

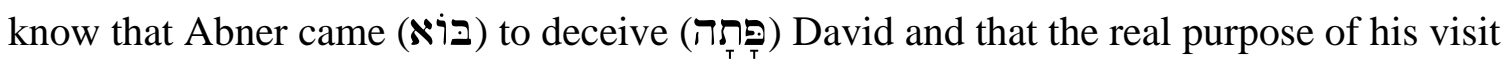

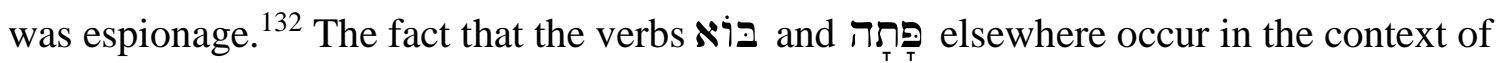
sexual seduction provides another link between Joab's speech and the dialogue between Abner and Ish-boshet at the beginning of the narrative, where Abner is accused of having come in (ב⿱ $)$ to Saul's concubine. ${ }^{133}$ As Leithart notes, the connection shows that

Joab...accused Abner in much the same way that Ishbosheth had: Joab suspected Abner was plotting a political rather than sexual seduction, but the idea was similar. Joab, like Ishbosheth, believed that Abner had designs on the throne, David's rather than Ishbosheth's. ${ }^{134}$

In Joab's view, David should have recognized this as well because he knows Abner (v. 25a). Yet this is precisely the problem, for, as suggested above, David does not really know Abner and his true motives because he failed not only to communicate with YHWH but also to ascertain whether the general has truly had a change of heart. Because of this, David is unable to refute Joab's accusation, which may explain why no answer from David is recorded at the end of Joab's speech. Though the narrator significantly does not note that David feared his general as he did in Ish-boshet's case back in v. 11, David's surprising silence nevertheless associates him at least partially with the weak son

${ }^{132}$ As Youngblood notes, this accusation is also "ironic in light of his [Joab's] own subsequent treachery (v. 27)." (Youngblood, "1 \& 2 Samuel," 838)

${ }^{133}$ Alter, The David Story, 213.

${ }^{134}$ Leithart, A Son to Me, 192. 
of Saul who is similarly powerless against Abner. ${ }^{135}$ This does not bode well for what is to come.

Verse 26

Yet David's silence also suggests that what is about to transpire was not initiated by him, but is solely Joab's doing. ${ }^{136}$ While Joab sharply criticizes the fact that Abner was able to depart unhindered, it is ironically his own departure from David that is "worthy of suspicion," 137 as will soon become apparent. Significantly, there is no mention of peace anymore as the angry Joab (both literally as well as figuratively) goes out from his silent king and sends messengers after Abner. ${ }^{138}$ Instead, the verb the preposition אֵַַח remind of the previous chapter, where Joab and Abner went out (איָד pursue after (ֵ) $)$ Abner $(2: 19,24)$, ominously intimating that the pursuit of Abner, which was abandoned at the end of 2 Sam 2, has been resumed and that the bloody conflict between Joab and Abner will now continue. This is further hinted at by the reference to the cistern/well of Sirah in v. 26, a place of water that reminds of the pool of

${ }^{135}$ Firth, $1 \& 2$ Samuel, 350; Morrison, 2 Samuel, 55.

${ }^{136}$ Cartledge, 1 \& 2 Samuel, 393.

${ }^{137}$ Fokkelman, Throne and City, 100.

${ }^{138}$ The sending of messengers reminds of the first half of the narrative where Abner (v. 12) and David (v. 14) did the same. Thus, "sending messengers is an important theme in this chapter with each new sending linked to claims of political power..." (Firth, $1 \& 2$ Samuel, 350). In contrast to Abner and David, who use non-violent means to demonstrate their power, Joab resorts to murder. 
Gibeon, where the conflict began in the previous chapter. ${ }^{139}$ It is from this cistern/well that Joab's messengers bring Abner back (hiphil of ששוב). Thus, he who just a few verses ago commanded a weeping husband to return (שפוב), must now do the same - a turn of events that will soon lead to more weeping.

It is at this point, just before Abner actually returns to Hebron, that the author interrupts the narrative flow with a short, but significant aside: "But David did not know." The statement, whose syntax emphasizes the subject, confirms what was already hinted at by David's silence in response to Joab's speech - the king does not play any part in Abner's murder. Thus, David stays true to the course he has pursued all along. He will not eliminate a rival in order to gain and secure the kingship that was promised to him. As commendable as this is, the aside also presents a not so subtle criticism of David and his kingship, especially since no object is given. Hence, "the verb, used in the absolute sense, painfully admits that David has lost sight of developments...."140 The king who was so intent on staying in control earlier in the narrative is now in danger of losing all control, as he is duped by his own general. This becomes possible because David apparently fatally misjudges the situation, ironically demonstrating precisely the lack of discernment that Joab accused him of with regard to Abner.

\footnotetext{
${ }^{139}$ If the name "Sirah" derives from the root Asahel's pursuit of Abner during which the former refused to turn aside (סוֹ) twice (2:21, 23) - reminding the reader that Abner did not kill Asahel maliciously, but most likely in self-defense - and the latter wondered how he could lift up his face to Joab if he killed Asahel, a question that now receives a new urgency as the two men are about to meet again for the first time since that fateful day. At the same time, the name may be mentioned just prior to Abner's death to remind of the general's own turning aside, i.e. his defection (סרָָ) from Ish-boshet and his rebellion (סרָז) against YHWH of which he will now reap the consequences. (Bodner, David Observed, 56).

${ }^{140}$ Fokkelman, Throne and City, 101.
} 
Verse 27

Yet David is not the only one who seems to be painfully unaware of the extent of Joab's rage and desire for revenge. Abner, too, appears to underestimate how dangerous the son of Zeruiah really is, as he returns to Hebron and agrees to a private conversation with him in the city gate. No meal is waiting for Abner this time, but only the vengeful Joab who ensures that his unsuspecting rival will not depart in peace a second time by striking him in the belly, the very body part where Abner struck Asahel in the previous chapter. The talionic nature of Joab's deed is further emphasized by the term last occurred in 2:23: just as Asahel fell "there" (ָָ

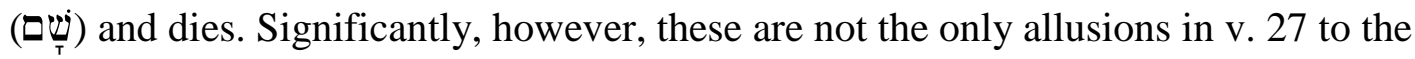
report of Asahel's death in 2:18-23. While the narrator's words at the end of the verse suggest that Joab viewed his killing of Abner as an act of blood revenge (Num 35:12; Deut 19:11-13), the information given at the beginning of the verse, namely that Joab

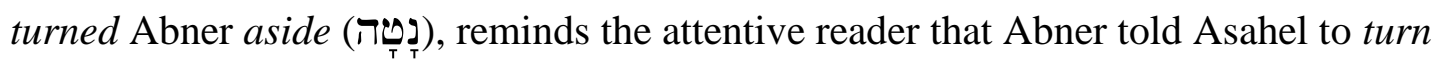
aside (נפָד ) this point of the narrative is thus a reminder of Abner's reluctance to harm Asahel, meaning that "blood revenge certainly was not justified in this instance." 142 Instead, Joab's deed constituted murder of the worst kind and showed him to be "a Torah violator", since the killing was not only unjustified but also perpetrated in the gate of a

\footnotetext{
${ }^{141}$ Matthew Newkirk, Just Deceivers: An Exploration of the Motif of Deception in the Books of Samuel (Eugene, OR: Pickwick Publications, 1995), 95.

${ }^{142}$ Smith, A Critical and Exegetical Commentary, 364.
} 
city of refuge, the very place where a manslayer was supposed to state his case before the elders in order to be admitted into the city (Josh 20:4). ${ }^{143}$ Like the brother he seeks to avenge, Joab thus takes matters into his own hands and executes judgment though he has no right to do so, in the process ironically making himself guilty of the very crime he wrongfully accused his victim of.

This ironic reversal is also made apparent by the final line in v. 27, where the narrator explicitly notes Joab's motive in killing Abner. In his angry speech to David, Joab wrongfully accused Abner in v. 25 of deceiving David by pretending to care about him and his kingship, when in reality he cared only about his own selfish interests, thus presenting a threat to David and his kingship. Yet as the final line of v. 27 makes clear, it is Joab (rather than Abner) who deceives David by pretending to care about him and his kingship, when in reality he cares only about his own selfish interests, thus presenting a threat to David and his kingship. Once again, the accuser has become the accused. At the same time, the explicit statement of Joab's very personal motive right after the report of the murder, if taken at face value, provides further evidence that David played no part in Abner's murder. The message is clear: Joab did not kill Abner to benefit David and his kingdom, but solely for personal reasons.

\footnotetext{
${ }^{143}$ Newkirk, Just Deceivers, 97; Leithart, A Son to Me, 193; Smith, A Critical and Exegetical Commentary, 364.
} 


\section{Verses 28-30}

Verse 28

David, who as noted earlier is unaware of Joab's scheme, only hears about the murder afterwards. Though on the one hand the wording of the opening line in v. 28 reflects negatively on David by emphasizing that like Joab back in v. 23 the king himself has been "overtaken by events and can do nothing more than react,"144 on the other hand it may further hint at David's innocence regarding Abner's death. For one thing, the

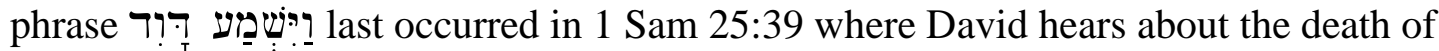
Nabal and praises YHWH for keeping him from evil, i.e. killing Nabal. ${ }^{145}$ Moreover, it may not be coincidental that the previous three occurrences of the phrase found in 2 Sam 2:1 and 1 Sam 24:6, 9 where the phrase emphasizes David's respect for Saul and his office, his unwillingness to kill Saul and his refusal to seize kingship from Saul by force. ${ }^{146}$ Following immediately after the report of Abner's murder these verbal links to two key passages (1 Sam 24 and 25) where David had the opportunity to eliminate an enemy, but did not, give further credibility to his declaration of innocence in the second part of the verse.

It is as if the shocking news of Abner's violent death forcefully jolts David out of the strange paralysis that seemed to have befallen him during his meeting with Joab, as

${ }^{144}$ Fokkelman, Throne and City, 105.

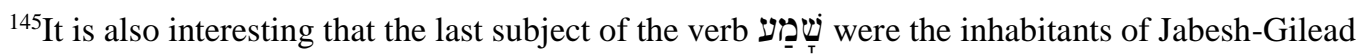
who heard about Saul's death, arranged for a proper burial and fasted (1 Sam 31:11-13) like David does in 2 Sam 3. David's reaction thus once again shows that he is like those of Jabesh-Gilead.

${ }^{146}$ See the analysis of 2 Sam 2:1 above. 
the formerly passive and silent king becomes active and begins speaking again. This once again sets him apart from Ish-boshet, who does not speak again after his accusatory question to Abner in v. 7 and appears to offer no resistance whatsoever to Abner's rebellion. Not so David. He may have failed to see through Joab, but he will not remain silent in the face of this atrocity. Instead, he issues a most likely public statement that consists of two parts. His first concern is the bloodguilt that threatens both him and his kingdom because of his potential involvement in Abner's murder. Thus, he begins his statement with an assertion that he and his kingdom are innocent forever before YHWH of Abner's blood. It is the first time in this literary unit that the divine name is found on David's lips. He who seemed so self-sufficient up to this point now turns to YHWH in his hour of need. Significantly, he makes no attempt to prove his innocence but, like Abner at the beginning of the narrative, claims the Deity as his judge, thus recognizing not only the seriousness of the crime but also that both he and his kingdom are ultimately accountable to YHWH. Hence it is of secondary importance whether he is considered innocent by the people (or the reader, for that matter!). What matters foremost is his innocence before YHWH and His law. David's emphatic אַמְזלָכָה as well as the term provide further links to Abner's speech in vv. 8-10, highlighting once more the contrast between the two men. While the selfish Abner shows no true concern for Ish-boshet's kingdom (which he himself brought about!) and never provides a straightforward response to the accusation that he slept with Saul's concubine, David is concerned not 
only for himself but also for his kingdom and clearly states his innocence though there is no indication in the text that he has been directly accused (yet). ${ }^{147}$

Verse 29

In the second part of his statement David then turns his attention to Joab. The blood of which David and his kingdom are innocent is to fall on Joab's head and on the whole house of his father. ${ }^{148}$ This is to manifest itself in a fivefold curse whose elements fall into the categories of (1) weakness and disease, (2) war and violent death and (3) hunger and famine and thus "are essentially a summary of the litany of Torah curses directed against Israelites who violated Yahweh's covenant (cf. Lev 26:14-39; Deut

${ }^{147}$ McCarter, II Samuel, 118. While it is of course possible to question and even doubt the veracity of David's assertion, as some have done (see e.g. Vanderkam, 533; Halpern 83-84), especially in light of (1) David's silence in response to Joab's speech and (2) the problems that might have arisen had Abner actually occupied a position of high rank in David's army, it is nevertheless quite plausible that David was indeed innocent, unless one assumes that the entire narrative has been drastically revised. If, however, the basic outline of the story is accepted, it must be concluded that at least at this point David had more to lose than to gain from Abner's death. As Campbell, 2 Samuel, 47, correctly notes, "the whole tenor of the story from the outset strongly suggests that it would have been in David's interest to keep Abner alive, at least until the merger of the kingdoms was effected. If David was a far-sighted and ambitious politician, the elimination of this middleman on the eve of the successful consummation of favorable negotiations would appear an incredibly inept blunder. At this point, David's ambitions were not threatened by Abner; Joab's were." See also Anderson, 2 Samuel, 61 and Hertzberg, I \& II Samuel, 261.

${ }^{148}$ Again, the wording reminds the attentive reader of Abner's speech in v. 8, where he asks whether he is a dog's head and reminds Ish-boshet of the חס्. he showed to the house of his father Saul. In this way the house of Joab is associated with the house of Saul, the only other house of a father in 2 Sam 3. In light of this, it does not appear accidental that the only occurrence in Samuel of the combination and נִקִי prior to 2 Sam 3:28 is found in 1 Sam 19:5 where Jonathan asks Saul: "Why then will you sin against innocent blood, to kill David without a cause?" The same question could be asked of Joab with regard to his murder of Abner. In contrast to David, both Saul and Joab are willing to shed innocent blood in order to defend their honor and secure their power and headship. Yet as the contest between the twenty-

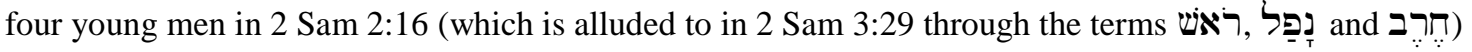
shows, those who seek headship by way of violence will be destroyed by it. 
28:15-68). ${ }^{149}$ In this way the contrast between David and Joab is once again emphasized: while the former is innocent before YHWH, the latter is guilty before YHWH and must therefore bear the appropriate and just punishment. Since Joab sought to restore the honor of his family in a dishonorable and unjustified way by way of murder, his family will now be forever associated with dishonor and death and hence share the fate of the fallen houses of Saul and Eli. ${ }^{150}$

Verse 30

That the curse against the whole house of Joab's father is just also becomes apparent in v. 30, where the reader is informed that Joab's brother Abishai was involved in Abner's murder as well. In addition, the wording and the chiastic arrangement of the verse once more emphasize that the murder was unjustified for while Joab and Abishai

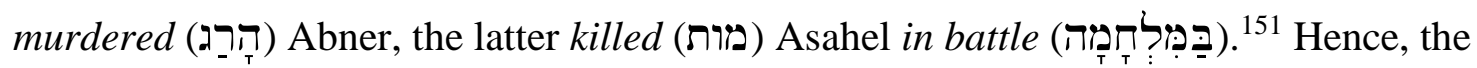
verse, which at first glance might appear superfluous, shows that David's pronouncement against Joab and the whole house of his father is appropriate and just.

${ }^{149}$ Bergen, 1,2 Samuel, 313.

${ }^{150}$ Like the house of Saul, the house of Joab will not lack one who falls by the sword (1 Sam 31:16) and like the house of Eli, it will never fail to have one who lacks bread (1 Sam 2:36).

${ }^{151}$ The chiastic structure of the verse is as follows:

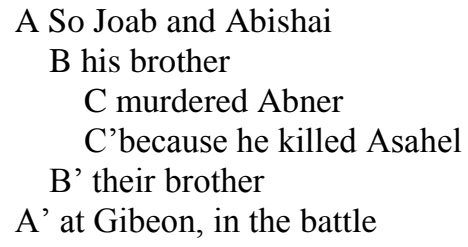


Nevertheless, it must be asked why David did not punish Joab and Abishai more severely, especially since he had both the young Amalekite who claimed to have killed Saul in 2 Sam 1 and the sons of Rimmon who killed Ish-boshet in 2 Sam 4 executed. While no direct answer is provided by the narrative, a careful reading of the text and comparison with the already mentioned cases in 2 Sam 1 and 4 helps to shed at least some light on the matter. It is noteworthy, for example, that both the Amalekite and the sons of Rimmon are outsiders who do not belong to David's camp. Joab, on the other hand, is not only an insider who is even related to David but also appears to hold quite a bit of power and influence within David's kingdom. This already becomes apparent in 2 Sam 2, where Joab leads David's troops and negotiates with Abner. Joab's power is further underscored by his speech to David and David's lack of a response in 2 Sam 3:2425 as well as by the fact that according to 3:23,31 not only the whole army but also a significant part of the people is "with him" (i.e. Joab). Together with David's statement in 3:39 that he is weak, though anointed king, and that the sons of Zeruiah are too hard/difficult for him, these hints suggest that David's failure to execute Joab and Abishai was not due to lenience but instead most likely resulted from a lack of power on David's part to bring the two brothers to full justice. This conclusion, if correct, does not fully exonerate David, however, for the reader cannot help but wonder whether David himself did not at least in part weaken his position through his apparent passivity with regard to finishing the conquest and his decision to make a covenant with Abner without consulting YHWH. If so, this would once again emphasize the importance of these aspects (i.e. completing the conquest and divine guidance) for the success of David's kingship. 


\section{Verses 31-37}

Verse 31

As the narrative moves on to Abner's funeral in v. 31, the focus remains on the now very proactive and resolute David, who continues to take charge of the situation and thus once more proves that he is a capable leader. Though he seems unable to execute capital punishment on the murderers, he is not satisfied with simply publicly condemning their deed and pronouncing a curse upon them. In stark contrast to his earlier silence, he now boldly addresses Joab and all the people with him directly, commanding them to not only engage in the customary mourning rites but to also walk in front of Abner's bier in the funeral procession. ${ }^{152}$ In this way David prevents Joab and all who might support his course of action from exulting over Abner's death, instead giving them an opportunity to reflect on the horror of Joab's deed. He thus makes it clear that Abner's death is not a cause for joy but for great sadness and mourning. The fact that Joab and those with him must respond in the same way David himself did to the death of Saul (see 2 Sam 1:1112), also serves as a further reminder that David will not help himself to the throne by force, once more distancing the king from the murder.

While Joab and the people with him are to mourn before Abner, David walks behind the bier - a spatial separation that aptly reflects the ideological distance between the two men. After all, it was Joab who pursued after (ָㅗำ Abner in the previous chapter (2:24) and sent messengers after (אַחרְרי) him prior to murdering him in the gate of Hebron (3:26). David, on the other hand, honors Abner even in his death by walking

${ }^{152}$ Driver, Notes on the Hebrew Text, 251; Fokkelman, Throne and City, 108. 232 
behind (אַחרִיר) the bier as the slain general is carried to his rest. At the same time, David's walking behind the bier and weeping (구국) reminds of Michal's husband Paltiel walking

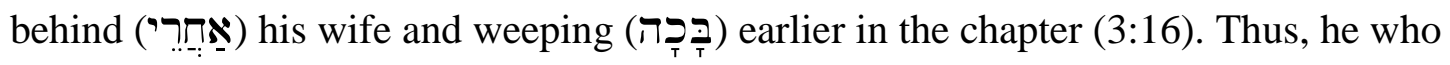
sought to demonstrate his power and unite the kingdom by separating a husband from his wife now himself feels the pain of being separated from the one he had entered into a covenant with. Significantly, however, it is precisely in this moment of loss and mourning that David rises to true greatness and is most powerful. ${ }^{153}$ A total of seven times he is explicitly called "king" in this part of the narrative, as he gains the respect and support of "all the people" through the way he responds to Abner's death. ${ }^{154}$ What Abner failed to accomplish in his lifetime, namely, to bring David the kingdom so that he could reign over all the people, is thus achieved in the aftermath of his death. ${ }^{155}$

\section{Verse 32}

The one who commended the men of Jabesh-Gilead for burying Saul, now ensures that his former adversary Abner receives a proper burial as well. Significantly, the corpse is not taken to Abner's hometown in Benjamin but buried in the royal city of Hebron, the ancient burial ground of the patriarchs (Gen 23:19; 25:9-10; 50:13). In this

\footnotetext{
${ }^{153}$ Bergen, 1,2 Samuel, 314, notes: "For the first time in the biblical narrative - and in the very midst of Abner's funeral procession, at that - the writer calls David "the king" (Hb. hammelek) in a nonquotational clause. For the writer - and thus for the astute reader - this tragedy transformed David; it provided a forum in which he could display his truly regal nature, and neither he nor the nation would ever be the same again."
}

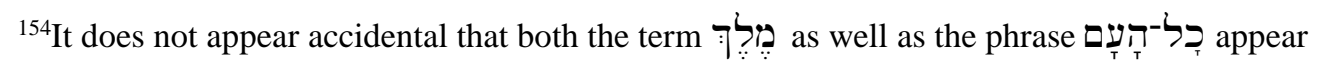
seven times in vv. 31-39, further highlighting the close connection and unity between the two entities.

${ }^{155}$ Leithart, A Son to Me, 194; Bergen, 1,2 Samuel, 314. 
way "the king honors Abner and the alliance he made with him." ${ }^{156}$ As already noted, the unity David has been seeking throughout the narrative now begins to become a reality as the king lifts up his voice and weeps at Abner's grave and all the people follow his example. Thus, it is through a public demonstration of genuine grief over the death of his former enemy that David achieves what he failed to accomplish through demands and demonstrations of power earlier in the story. King and people become one in the act of weeping over a senseless death.

This unity is also highlighted through the contrast to the story in 1 Sam 30 where

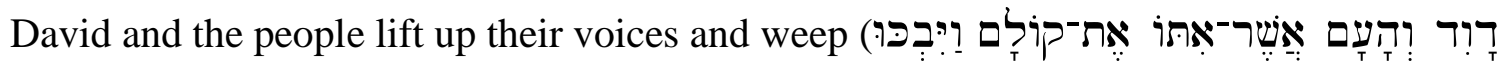

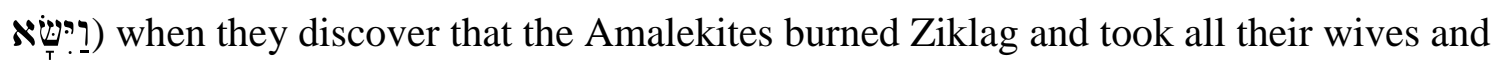
children captive (30:4). Immediately afterwards, however, the people want to kill David (30:6). The contrast to the present narrative is striking, for here the people are truly united with David as they weep with him and there is no mention that anyone wants to kill him a first indication that the people do not consider David to be guilty of Abner's murder. Further decreasing the likelihood that David had a hand in the general's death is the fact that the phrase "lifted up his voice and wept" in 2 Sam 3:32 also reminds of 1 Sam 24:16 where Saul responds in the same way when he discovers that David spared his life. ${ }^{157}$ The point of this verbal link to 1 Sam 24 is clear: would a man, who in the past refused to kill his enemy, even when he had the perfect opportunity to do so, be involved in the devious murder of another man, who at the time of his death was not even an enemy anymore?

\footnotetext{
${ }^{156}$ Morrison, 2 Samuel, 60.

${ }^{157}$ Auld, I \& II Samuel, 382.
} 
While not impossible, David's past behavior strongly argues against it. As Auld notes, the link to 1 Sam 24 is also significant because Saul's question just a few verses later in v. 20 (Who has ever found an enemy, and sent the enemy safely away?) is applicable to the present narrative as well and once more highlights the contrast between David and Joab. ${ }^{158}$ While David spared his enemy when he found him, Joab did not. In this way the king is again distanced from Joab and his crime.

Verses 33-34

Just as he had done for Saul and Jonathan, David sings a lament for Abner. For the third time the author emphasizes that it is the king who acts in this way. The lament is composed of two monocola featuring similes (vv. 33b; 34c) surrounding a bicolon made up of two passive clauses about limbs (v. 34ab), yielding a chiastic arrangement:

A Did Abner have to die the death of a fool? (v. 33b)

B Your hands were not bound (v. 34a)

B' nor were your feet put in fetters. (v. 34b)

$A^{\prime}$ As one falls before sons of wickedness you have fallen. (v. 34c) ${ }^{159}$

The opening rhetorical question is highly significant, not just within the present narrative but also in light of the larger narrative, poignantly capturing the tragedy of Abner's death: Did Abner have to die the death of a fool? According to David, he did not, for his hands were not bound and his feet had not been put in fetters, i.e. he was a free man who had not been arrested for some crime. Yet this freedom could not save him, for

${ }^{158}$ Auld, I \& II Samuel, 382.

${ }^{159}$ Fokkelman, Throne and City, 110. 
he was treacherously killed by sons of injustice who made him look like a fool. Thus, David once more condemns the murder, clearly identifying it as an act of treachery and injustice. $^{160}$

Yet in spite of this clear condemnation of the murderers, a close reading of the lament reveals several terminological links to previous narratives that remind the attentive reader of Abner's own foolishness which in the end contributed in no small degree to his premature and unnecessary death. The term נברד in the opening line of the lament, for instance, points back to Saul's alter ego Nabal who just like Israel's first king foolishly opposed David instead of supporting him and thus treated David in much the

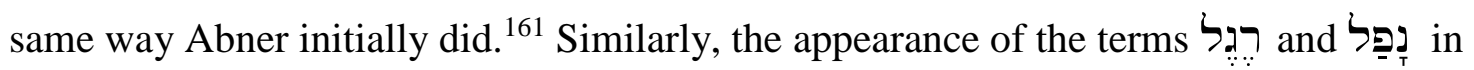
the third and fourth lines, respectively, reminds the reader of the story in the previous chapter, where Abner foolishly suggested a contest to determine the issue of headship over Israel which led to the fall (נָפָָּל) of all twenty-four contestants which in turn led to a

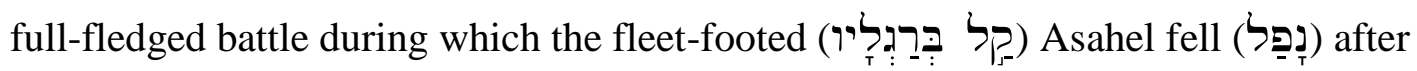

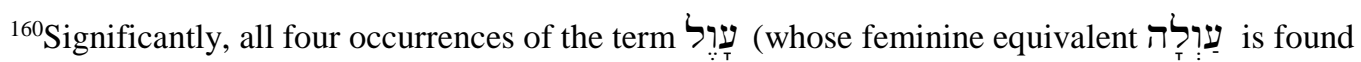

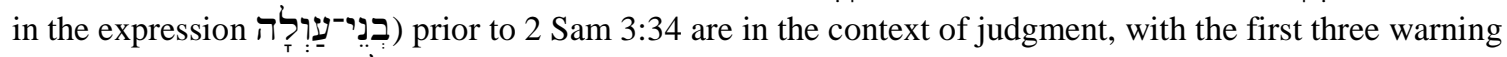
Israel not to do injustice (עָוָר) in judgment (Lev 19:15, 35; Deut 25:16). Yet this is precisely what Joab and Abishai did when they killed Abner in the gate (which served as the place of judgment). Thus they failed to reflect YHWH who is "without injustice" (אין עִיָ, Deut 32:4).

${ }^{161} \mathrm{~J}$. Cheryl Exum, Tragedy and Biblical Narrative: Arrows of the Almighty (Cambrigde: Cambridge University Press, 1992), 106; Youngblood, "1 \& 2 Samuel," 841. Note how the syntactical

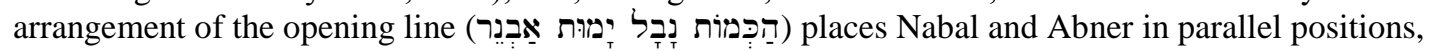
inviting the reader to draw a connection between the two men. At the same time, the link to 1 Sam 25 once more highlights the contrast between David and Joab. While David spares Nabal, thus allowing YHWH to decide Nabal's fate, Joab takes matters into his own hands and kills Abner, even though, in contrast to Nabal, Abner had given up his opposition against David at that point. Thus, the allusion further condemns Joab, while at the same time suggesting that as in the case of Nabal Abner's fate should have been left in the hands of YHWH.
} 
being killed by Abner - the very event that precipitated and foreshadowed Abner's death. Furthermore, the reference to the general's unbound hands (ידָ $\left.\mathbf{T}^{\top}\right)$ and feet recalls not only his haughty promise that his hand (ידT $)$ would be with David to bring all Israel to him (2 Sam 3:12), but also his tireless efforts throughout the present narrative to bring just this about and thus to once again become the "king-maker" - a clear indication that in spite of giving up his opposition against David he has not really changed. That he dies looking like a fool is therefore quite appropriate. His death reflects his life and shows who he really is.

Verse 35

Yet for David and all the people this is no reason to rejoice or to ridicule the slain general. Instead, the king's lament causes the people to weep even more over Abner as they realize how tragic his end really was. They also show concern for David as they come to give him bread. ${ }^{162}$ But he who just a few verses ago declared that there should never fail to be one who lacks bread in Joab's house, now voluntarily abstains from food just as he had done after the death of Saul and his sons. To show how serious he is about this fast, David even swears an oath that reminds of Abner's vow in the opening scene of the story (v. 9). As already noted above, a comparison of the vows within their immediate contexts reveals the contrasting attitudes of the two men. While Abner is motivated by

\footnotetext{
${ }^{162}$ In a story dominated by coming and going, this is the final coming that is significantly not followed by a departure. Thus the episode closes with David surrounded by all the people and then (in vv. 38-39) by his servants. The scene stands in striking contrast to the earlier feast that David made for Abner and his men when they came בואי) to him at Hebron as well as to Joab's angry tirade when he came בואיא) to the king.
} 
selfishness and pride, David is prompted by unselfishness and respect for the dead general. Thus, it becomes evident once more how different the two men really are.

That the same is true for David and the sons of Zeruiah becomes evident yet again by a careful reading of v. 35, for the two temporal references mentioned there (הַיוֹ

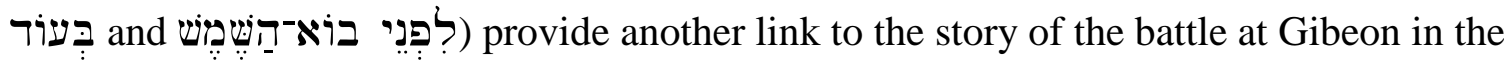
previous chapter. ${ }^{163}$ Before the sun sets over Gibeon Joab and Abishai are busy pursuing Abner, who has just killed their brother Asahel (2:24). By contrast, David is busy mourning and fasting for Abner, who has just been killed by Joab, before the sun sets over Hebron in chapter 3. While Joab and Abishai are focused entirely on avenging Asahel's death, David is very much concerned about expressing his sorrow over the death of Abner. ${ }^{164}$ The end results are also strikingly different. Whereas Joab and Abishai's attitude and actions prolong the conflict and leave Israel more divided than ever, David's attitude and actions stifle all further violence and lead to first hints of a united Israel. ${ }^{165} \mathrm{In}$ light of this it seems significant that in contrast to chapter 2 night never falls in chapter 3. ${ }^{166}$

${ }^{163}$ Fokkelman, Throne and City, 113.

${ }^{164}$ As David's words in vv. $28-29$ and 39 show, this does not mean that he is not concerned about justice. In contrast to Joab and Abishai it is simply not his sole focus.

${ }^{165}$ Note especially the repeated references to "all the people" in vv. 31-37 as well as the reference to "all Israel" in v. 37.

${ }^{166}$ This would also make sense in light of the fact that already in chapter 2 Hebron was associated with light and daytime (see 2 Sam 2:32). 
Verse 36

Following David's oath, the focus of the narrative once more switches to the people who have carefully observed David during the funeral service and are now ready to pronounce their verdict. According to v. 36, not just David's refusal to eat before sunset but his entire reaction to Abner's death is deemed good by all the people. This complete agreement of the people with David is once again reminiscent of 1 Sam 18 where the same expression ("good in the eyes of all the people") is used to describe the people's acceptance of David as commander of the army (v. 5). At the same time the wording in v. 36 brings back to mind Abner's efforts to convince Benjamin and Israel to accept David as their king (v. 19). There it seemed that both groups remained hesitant towards David and would only accept him on their terms (i.e. what was good in their eyes), making further negotiations necessary. Here at the end of the chapter, on the other hand, the situation is much more positive. Instead of making a feast for Abner, David abstains from food and mourns for the general, yet precisely these acts of sorrow and respect for one that had been hostile to David for so long bring about acceptance and unity between king and people. The contrast thus highlights the failure of the earlier approach to fully gain the support of the people and suggests that genuine care and respect for others are more effective means for achieving this goal. It is in his "weakest" and most vulnerable moment that David is most at one with his people.

Verse 37

David's deportment at Abner's funeral also convinces the people and even all Israel of his innocence with regard to the general's death. The recognition (ידָיָ 
people confirms not only that David indeed did not know (יָָָ) that Joab brought Abner back to Hebron (v. 26) but also David's own claim in v. 28 , further emphasizing the unity between king and people. That at the end of the narrative David is considered innocent by the people of a deed by which he could have secured his throne also presents yet another contrast to Abner, who at the beginning of the narrative was deemed guilty by Ish-boshet of an act that could be interpreted as making a claim to the throne. Significantly, the people reach this conclusion because of David's reaction to Abner's death, which once again demonstrates that contrary to Abner's earlier claim (v. 8) it is David rather than the self-serving general who has shown true tọ the house of Saul.

\section{Verses 38-39}

Verse 38

The narrative closes with a final statement by the king that is addressed to his servants. The switch from the general term "people" to the more intimate "servants" is appropriate on the heels of the people's positive response to David which climaxes in their recognition of his innocence (vv. 36-37) ${ }^{167}$ For the first time in the narrative the king is now portrayed as being surrounded by his loyal subjects. Instead of basking in the moment or drawing attention to himself, David uses the opportunity to provide a closing statement on the events of the day in which he mentions all three major protagonists of the story. He begins with Abner and, as in his lament, once more seeks to make his listeners realize the full import of the general's death. It was not just any citizen who fell

${ }^{167}$ Auld, I \& II Samuel, 384. 
that day, but a prince and a great one in Israel. Unlike Joab, who spoke only negatively of Abner and falsely accused him of espionage (v. 25), David thus once again demonstrates his great respect for Abner and reminds his servants who he really was. ${ }^{168}$

\section{Verse 39}

Next David turns to himself. With surprising candor he describes himself using the rare adjective 7 , meaning "tender," "sensitive," or "soft" - rather unusual qualities for a king which stand in striking contrast to Abner's greatness (v. 38) and even more so to the hardness of the sons of Zeruiah (v. 39). In this way, "David stands rather alone, if not naked, between the great man of v.38b and the tough guys of $39 \mathrm{~b} . " 169$ The contrast in particular to Abner is further stressed by David's emphatic אנזכי which also reminds of his earlier reply to the general (v. 13), thus once more highlighting the development he has undergone within the narrative. The one who sought to demonstrate his power at the expense of another's feelings is now confronted with his own sensitivity and vulnerability in the face of all the violence between brothers that has climaxed in Abner's grisly death. Yet it is precisely by humbly recognizing and revealing these seemingly weak qualities that he wins the support of the people and is thus closer to becoming king over a united Israel than when he sought to achieve this goal through a demonstration of power.

Standing between his statements concerning the murderers and their victim, David's self-description nevertheless also points to his inability to properly punish the

\footnotetext{
${ }^{168}$ The two statements are connected through the term ידָיָ that occurs at the beginning of both. ${ }^{169}$ Fokkelman, Throne and City, 117.
} 
culprits at that point. ${ }^{170}$ Though he is the anointed king, he is still in such a vulnerable and weak position that "these men," as he disdainfully calls them, are too difficult for him to handle. Yet David does not capitulate as Ish-boshet did with Abner at the beginning of the episode. Unlike the son of Saul, he does not fall silent but instead publicly distances himself from the murderers. Most significantly, he also utters one final, decisive line in which he calls upon YHWH to repay the evildoer according to his evil. In his hour of weakness David thus once more turns to the ultimate judge, whom he also appealed to back in v. 28. He who alone is able to truly declare David innocent is also the only one who can truly avenge the wrong that has been done. In this way David again recognizes that true justice and peace in his kingdom can only be brought about by YHWH. ${ }^{171}$

\section{Implications for the Nature of David's Kingship}

As the above exegetical analysis has shown, the present literary unit provides further insights into the nature of David's kingship, not only through the contrast to Ishboshet's kingship but also through the contrasting portraits of David himself and the development he undergoes within the narrative. While in the first part of the narrative he seems strong and in control, a close reading of the text reveals that, as in the previous literary unit, his course of action is less than ideal as he begins to abandon some of the

\footnotetext{
${ }^{170}$ Timo Veijola, Die ewige Dynastie: David und die Entstehung seiner Dynastie nach der deuteronomistischen Darstellung (Helsinki: Suomalainen Tiedeakatemia, 1975), 31.

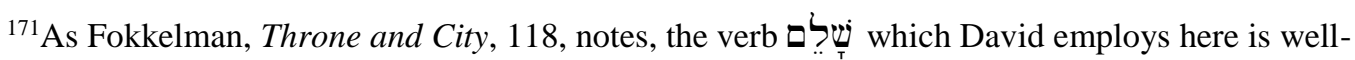
chosen. At the end of a narrative in which David attempts but ultimately fails to bring the conflict between

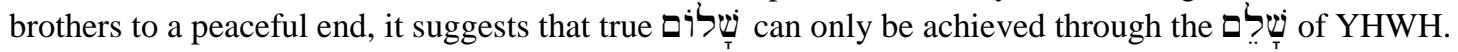


foundational elements of his kingship highlighted in 2 Sam 2 in order to gain kingship over all Israel through human efforts instead of fully relying on YHWH like he had in the past. Significantly, this approach, which causes David to become more and more like Abner, does not bring about the desired outcome, but only leads to sadness and strife. The turning point comes with Abner's death, for it is this event which at first glance seems to severely threaten his kingship and end his hopes of reigning over a united Israel that brings about a change in David and causes him to return to his former ways, as a result of which his kingship is more secure and Israel more united than at the beginning of the narrative. Though he is now outwardly weak, he is thus actually in a stronger position than in the first part of the story. A careful reading of the literary unit therefore suggests that David's kingship can only thrive and endure as long as David remains true to himself and to the principles he embraced and championed both during his rise to power and at the outset of his reign.

\section{The Legitimacy of David's Kingship}

Chosen by God. David's divine election is explicitly affirmed by Abner in his speech to the elders of Israel in v. 18, revealing that even those who formerly opposed him know that he has been chosen by God to be king over all Israel. That the transfer of Michal "ends" at Bahurim seems to serve as a subtle reminder that it is this divine election, rather than his relationship to Saul, that qualifies David to be Saul's legitimate successor.

Recognized by the people. Though it is not explicitly stated anywhere in the narrative that the people recognize David as king, it seems to be implied in v. 37 where 
all the people and all Israel recognize that it was not of the king to kill Abner.

Significantly, this recognition is not achieved through David and Abner's elaborate efforts in the first part of the narrative, but comes as a result of David's decisive, yet humble and heartfelt reaction to Abner's death in the second part of the story. Thus,

David is recognized as king when he is outwardly weakest and acts most "unkingly," but relies most strongly on YHWH.

Qualified by his character. Though David's behavior in the first part of the narrative demonstrates that he is far from perfect, his refusal to take revenge on his former enemy Abner as well as his response to the general's death in the second part of the story once again reveal his true character. Instead of rejoicing over or condoning his death, David mourns greatly over him, while condemning those who murdered him.

Qualified by his personality. In contrast to the generally passive and helpless Ishboshet, who becomes active only temporarily during the opening dialogue with his general Abner before falling back into his old ways, David is once more presented as a capable man of action who takes the initiative through most of the narrative and only temporarily becomes passive during the encounter with his general Joab. Unlike the son of Saul, who fearfully falls silent before Abner, David fearlessly stands up to Joab, publicly condemning his deed and demanding that he actively participate in mourning for Abner.

\section{Foundational Elements of David's Kingship}

Peace. Though David's conduct is not always ideal in this literary unit, he does not once resort to violence to accomplish his purposes as Joab and Abner do, but instead 
publicly condemns the use of such means. As is emphasized by the three-fold repetition of Abner's departure in peace at the center of the literary unit, David is not interested in revenge but rather seeks a peaceful solution to the conflict at hand. As in the past, he will not gain kingship over a united Israel through the use of violence. Nevertheless, his efforts for peace are only partially successful. As David himself suggests in the final verse of the narrative, it is only through the righteous judgment of YHWH that true and lasting peace can be achieved.

Humility and proper self-assessment. While the reader is reminded of David's humility through the verbal link to 1 Sam 24 in v. 8 the following verses in the first part of the narrative show that David is in danger of becoming proud and demanding like Abner. After the death of Abner, however, David once more demonstrates great humility as well as self-awareness as he leads the people in mourning for the dead general and openly admits his own weakness. The favorable reaction of the people in vv. 36-37 that stands in marked contrast to their rather ambiguous and calculating response in vv. 18-19 once more highlights the importance of these elements for the success of David's kingship.

Strength and Continuity. As in the previous literary units, the weakness of Ishboshet's kingship is emphasized in the present narrative. Reduced to a pronoun in the opening scene of the narrative, the son of Saul is unable to stand up to his own general and can only helplessly and silently stand by while Abner makes good on his threat to transfer the kingdom to David and thereby effectively end Ish-boshet's kingship. When he does act, it is only to do David's bidding and return Michal - a highly significant transfer which Ish-boshet agrees to seemingly without any protest. 
David, on the other hand, is once again presented as a strong individual in the first part of the narrative. From the very beginning he is in charge of the negotiations with Abner and dictates the terms on which an agreement can be reached. Both Abner and Ishboshet are reduced to mere executors of his will. As in the previous literary unit, however, David's strength is not unproblematic, since it is employed selfishly and without concern for the people. Significantly, it also does not gain him kingship over a united Israel.

In the second part of the story David at first glance appears to be weak. Like Ishboshet, he cannot stand up to his general and is unable to prevent the outbreak of further violence. He even seems powerless to bring Abner's murderers to justice. Yet it is in this moment of weakness that David once again begins to fully rely on YHWH, enabling him to demonstrate great strength of character through the way he publicly condemns Joab's deed and deeply mourns for Abner. This in turn evokes a favorable reaction from the people that puts him in a stronger position than in the first part of the narrative. This development within the story thus suggests that only an inner strength resulting from full reliance on YHWH will ensure the continuity of David's kingship over a united Israel.

Fruitfulness and Life. The lack of any offspring mentioned in connection with Ishboshet and Abner in the opening scene of the narrative as well as the inability of Ishboshet to claim and protect his father's concubine contrast starkly with David's large family presented in the immediately preceding verses. The contrast once again highlights David's fruitfulness and associates his kingship with life and continuity. Ish-boshet's fruitlessness, on the other hand, foreshadows the death of his kingship. 
Respect and concern for others. Like Abner and Joab, David does not show much concern for others in the first part of the narrative, but instead seems to be driven largely by his own selfish agenda. This is emphasized in particular by the contrast between his calculating attitude in the matter of Michal and Paltiel's sorrow over losing his wife as well as by the striking disparity between David's apparent disregard for his servants returning from a raid and the elaborate meal he provides for Abner and his men. Unlike the two generals, however, David undergoes a change for the positive as the narrative progresses, for at Abner's funeral he once more demonstrates the kind of unselfish respect and concern for another which had characterized him in the past. As a result, he wins the favor and support of the people, emphasizing how important this attitude is for the success of his kingship.

Sorrow over evil. David's apparent indifference to the pain he inflicts on Paltiel in the first part of the narrative associates him with both Abner and Joab who never appear to sorrow over evil. Here also the death of Abner marks a turning point as David is forcefully reminded how terrible evil really is, prompting him to respond with profound sorrow as he did in the past. Thus, he makes it clear that evil is never a cause for joy but rather something to be grieved.

$70 \pi$. In contrast to his earlier practice that the reader is reminded of through the verbal link to 1 Sam 24 in v. 8, David does not appear to be motivated by true ion in the first part of the narrative, associating him with Abner who claims to show tor to the house of Saul but in reality is driven by selfish ambition. This changes with the death of Abner as David mourns greatly over the fallen general and ensures that he receives a 
proper burial, associating him with the men of Jabesh-Gilead who showed true to the house of Saul. Thus David once more displays the attitude which characterized him in the past, further establishing חֶֶ as a foundational element of his kingship.

Divine Guidance. Adding to the rather negative portrait of David in the first part of the narrative is the fact that he does not seek divine guidance, even though the allusions in vv. 12-13 to the stories of the patriarchs and Israel suggest that he should have done so. Instead of inquiring of YHWH as he had consistently done in the past, David attempts to take matters into his own hands. This course of action not only further associates him with Abner and Ish-boshet, but in the end also weakens his position as a leader instead of strengthening it. Rather than being in control of things, David fails to foresee the effect his covenant with Abner will have on Joab and ends up being overtaken by the developments in the narrative. In contrast to Ish-boshet, however, David does not remain helpless. Though he does not directly inquire of YHWH on what course to pursue, he does once again recognize his need for YHWH's help, invoking him to execute just judgment upon the evildoer. Thus, the narrative underscores how important YHWH's assistance and guidance are for David's kingship.

Freedom of choice. In contrast to his course of action in 2 Sam 2, where he showed concern for the well-being of the men of Jabesh-Gilead and gave them the free choice to accept him as their king, David symbolically demands the kingdom and thereby the loyalty of the people by ordering that Michal be returned to him in the present narrative. Yet this attempt to gain the loyalty of the people by force does not bring about the desired result as the people remain hesitant to accept him as their king. Significantly, it is when David appears to be least concerned about gaining kingship, but instead 
humbly demonstrates his sorrow over Abner's death, while at the same time clearly condemning the murder, that he freely gains the sympathy of the people and is thus closer to becoming king over all Israel than in the first part of the narrative.

Justice. From the very beginning the narrative is characterized by injustice that culminates in the unjustified slaying of Abner. While both kings are indirectly portrayed as incompetent judges and both fail to bring their generals to justice, David once more distinguishes himself from Ish-boshet by recognizing YHWH as the ultimate judge and turning those who have done evil over to his judgment. In this way the narrative emphasizes that ultimately true justice can only be administered by YHWH himself.

Unity. Though both David and Abner are intent on uniting Israel in the first part of the narrative, the process turns out to be rather complicated and they are unable to achieve a decisive breakthrough before their efforts are cut short by Abner's death. Yet in this very moment of crisis that could divide the nation even further David gains the respect and sympathy of the people as they observe his reaction to the general's murder. Thus, the narrative underscores that true unity is not achieved through demands and demonstrations of power but through genuine care and respect for others.

\section{The Purpose of David's Kingship}

Finish the conquest. As in the previous literary unit, there is no indication in the present narrative that David intends to continue fighting against Israel's enemies in order to complete the conquest. Having settled down in Hebron, he instead seeks to gain an inheritance on his own terms. Rather than uniting the nation, however, this strategy only leads to further strife on the domestic front. As the allusions to 1 Sam 18 and 30 as well 
as Josh 23 suggest, the better option for David would have been a continued concern for finishing the conquest, for in this way he had experienced the help of YHWH and earned the trust and support of the people in the past. Thus, the importance of this aspect for the success of David's kingship is once again emphasized. 
CHAPTER 4

EXEGESIS OF 2 SAMUEL 4:1-5:5

2 Samuel 4:1-12

Text

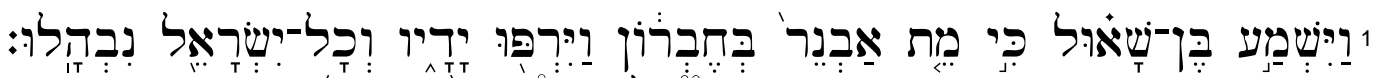

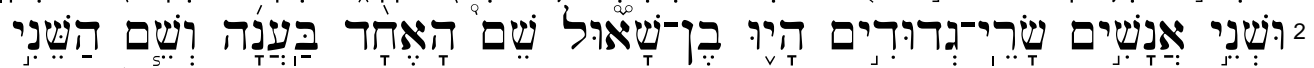

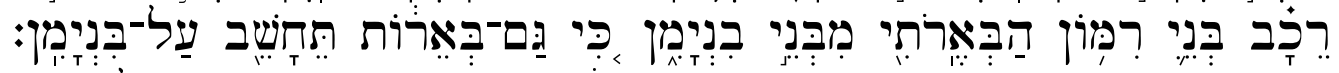

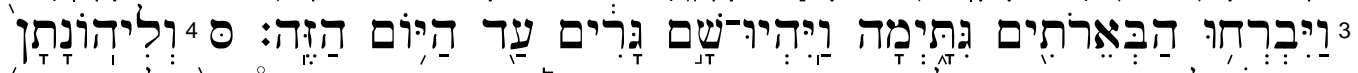

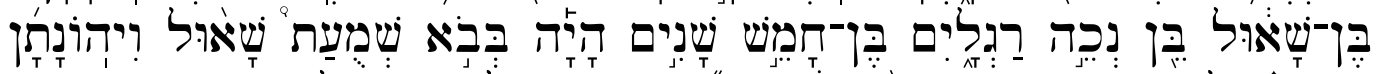

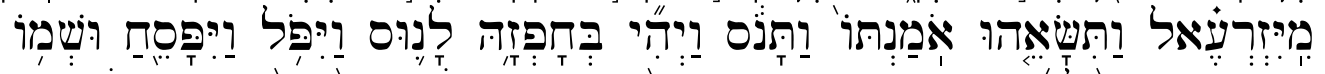

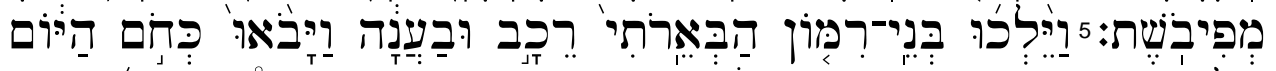

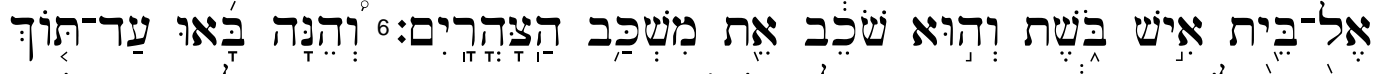

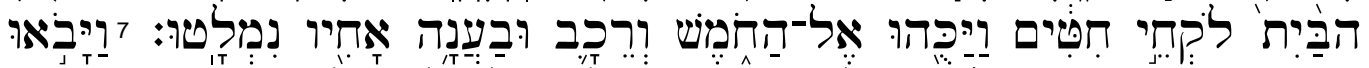

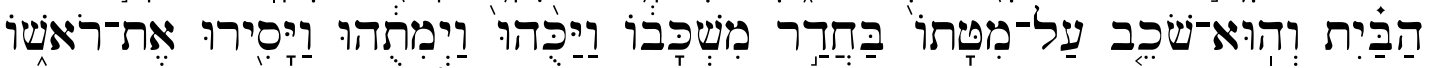

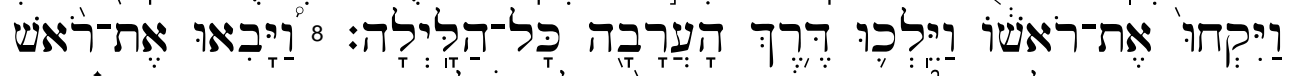

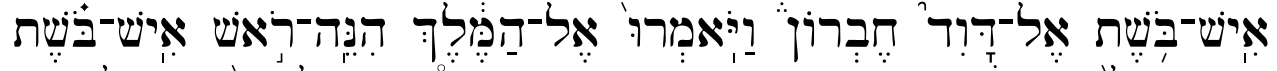

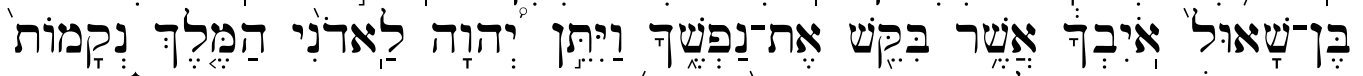

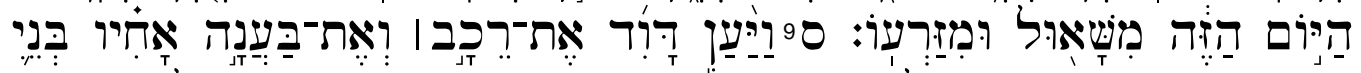

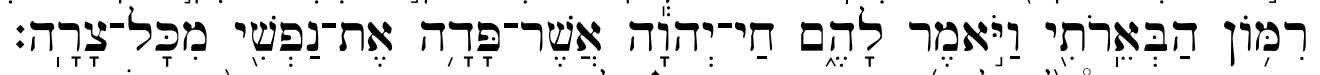

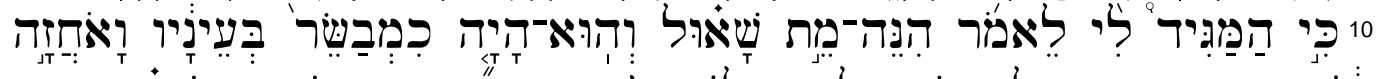

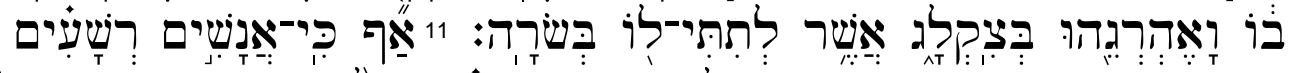

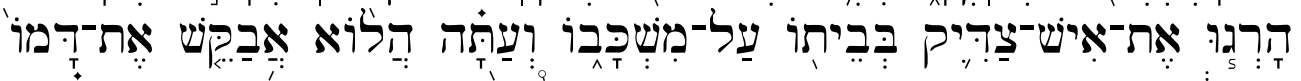

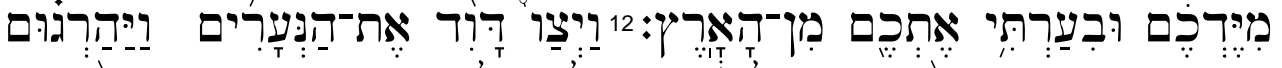

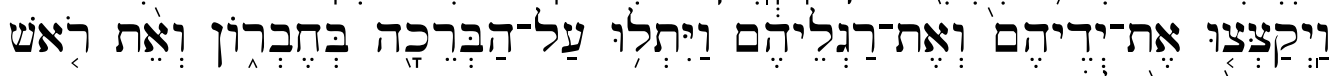

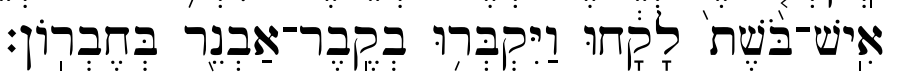




\section{Translation}

${ }^{1}$ When the son of Saul heard that Abner was dead in Hebron, his hands dropped and all Israel was alarmed. ${ }^{2}$ Now the son of Saul had two men, commanders of raiding bands. The name of the one was Baanah and the name of the other was Rechab, sons of Rimmon the Beerothite, of the sons of Benjamin, for Beeroth was also reckoned to Benjamin. ${ }^{3}$ But the Beerothites fled to Gittaim and have been sojourners there until this day. ${ }^{4}$ Now Jonathan, the son of Saul, had a son, crippled in the feet. He was five years old when the news about Saul and Jonathan came from Jezreel. His nurse had lifted him up and fled. But it came to pass that in her hurrying to flee he had fallen and become lame. And his name was Mephibosheth. ${ }^{5}$ So the sons of Rimmon, Rechab and Baanah, set out and came to the house of Ish-boshet at about the heat of the day. But he was lying down on a bed at noon. ${ }^{6}$ But they came into the midst of the house to take wheat and they struck him in the belly. And Rechab and Baanah, his brother, escaped. ${ }^{7}$ When they came into the house, he was lying in his bed in his bedroom. And they struck him and killed him and removed his head. And they took his head and walked the way of the Arabah all night. ${ }^{8}$ They brought the head of Ish-boshet to David at Hebron and said to the king: Behold, the head of Ishboshet, the son of Saul, your enemy who sought your life. The Lord has given my lord the king vengeance this day on Saul and his descendants. ${ }^{9}$ But David answered Rechab and Baanah, his brother, the sons of Rimmon the Beerothite, and said to them: As YHWH lives who has redeemed my life from all distress, ${ }^{10}$ when one announced to me, saying: Behold, Saul is dead and he was as a bearer of good news in his eyes, I took hold of him and killed him at Ziklag, which is the messenger's reward I gave him. ${ }^{11}$ How much more when wicked men kill a righteous man in his house on his bed shall I not require his blood from your hand and purge you from the earth? ${ }^{12}$ Then David commanded the young men and they killed them and cut off their hands and their feet and hung (them) over the pool at Hebron. But the head of Ish-boshet they took and buried it in the grave of Abner at Hebron.

\section{Delimitation}

There is general agreement among commentators that the present literary unit begins in v. 1 and ends in v. 12. A careful look at the text confirms that these are indeed the boundaries of the narrative. As Youngblood and others have noted, for example, the two verses form an inclusio, since both not only mention the same characters (Ish-boshet, 
Abner) and the same location (Hebron) but also contain the term $\mathrm{T}_{\mathrm{T}} \cdot{ }^{1}$ This keyword in turn connects the framing verses with the rest of the narrative where various body parts play a significant role. In addition, the expression these are the only two occurrences of the expression in the Old Testament without the addition of a personal name. Furthermore, the description of Ish-boshet in v. 1 "pose[s] the problem to which the plot will relate" ${ }^{\text {and }}$ andepares the reader for the king's ultimate demise just a few verses later. In spite of the reference to Abner's death as well as the keyword that could initially lead the reader to consider v. 1 as part of the previous unit, it thus seems best to view the verse as the introduction to the following episode.

The narrative is brought to a close with the execution of the murderers and the burial of Ish-boshet's head in Abner's grave in v. 12. Just like two of the three previous units, the present narrative thus ends with an entombment. While the events described in the following verses also take place in Hebron, the switch to a new group of characters

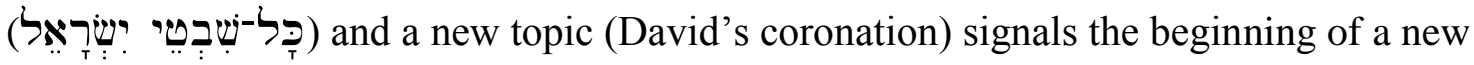
literary unit at 5:1. For these reasons the present literary unit is viewed as comprising all twelve verses of 2 Sam 4.

\section{Structure}

There are at least three different ways the literary unit can be arranged. First, as Youngblood has observed, the narrative may be divided into three parts that each consist

\footnotetext{
'Youngblood, "1 \& 2 Samuel," 843. See also Leithart, A Son to Me, 195.

${ }^{2}$ Fokkelman, Throne and City, 122.
} 
of three verses plus a concluding fourth verse featuring one or more body parts:

A. The dramatis personae (4:1-4)

1. Ish-Bosheth, Baanah, Recab (4:1-3)

2. Mephibosheth, lame in both feet (4:4)

B. The deed (4:5-8)

1. The murder of Ish-Bosheth (4:5-7)

2. His head brought to David (4:8)

C. The consequences $(4: 9-12)$

1. The verdict of David (4:9-11)

2. The execution of Recab and Baanah, whose hands and feet are cut off $(4: 12)^{3}$

Building on Sacon's suggestion, it also seems possible arrange the passage

chiastically. ${ }^{4}$ In both the introduction in vv. 1-4 (A) and the conclusion in v. 12 (A') body parts play a central role in highlighting the contrast between the sons of Saul and the sons of Rimmon. In addition, Abner and Hebron are mentioned in both parts. Parts B and B'

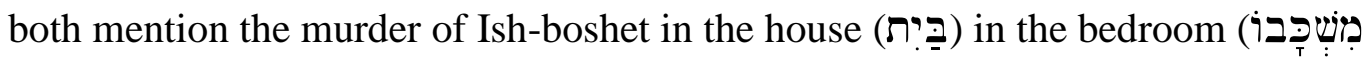

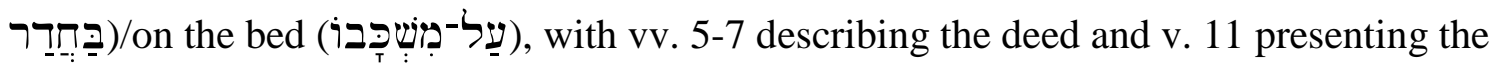
verdict. The center of the passage therefore comprises the speech of the sons of Rimmon in v. 8 and David's response in vv. 9-10. Both speeches involve news of death introduced by הִגag But while the sons of Rimmon speak of YHWH avenging David from the one

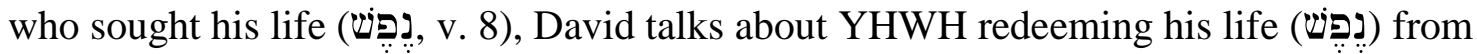
all distress (v. 9). This arrangement may be diagrammed as follows:

\footnotetext{
${ }^{3}$ Youngblood, “1 \& 2 Samuel,” 843.

${ }^{4}$ See Kiyoshi K. Sacon, "A Study of the Literary Structure of the 'Succession Narrative," in Studies in the Period of David and Solomon and Other Essays: Papers read at the International Symposium for Biblical Studies, Tokyo, 5-7 December, 1979 (ed. Tomoo Ishida; Winona Lake, IN: Eisenbrauns, 1982), 46-47.
} 
A Introduction: Sons of Saul vs sons of Rimmon (1-4)

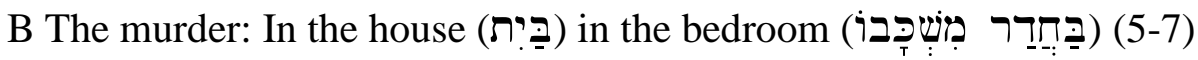

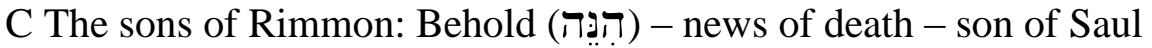

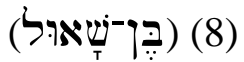

D Rechab and Baanah: YHWH avenged you from the one who sought your life (נֶֶֶ) (8)

D’ David: YHWH redeemed my life (נֶֶפשׁ) from all distress (9)

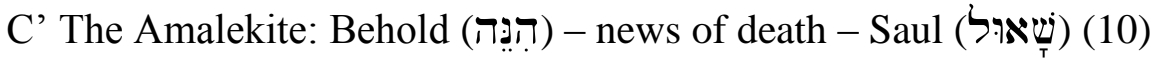

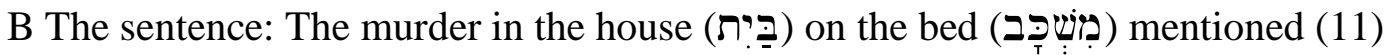

A' Conclusion: Son of Saul vs sons of Rimmon (12)

Alternatively, the narrative may also be divided into two parallel panels comprising vv. 1-7 and 8-12, respectively. The first panel features Ish-boshet and the sons of Rimmon, the second David and the sons of Rimmon. While the first part climaxes in the murder of Ish-boshet and the removal of his head, the second part ends with the execution of the murderers and the burial of Ish-boshet's head.

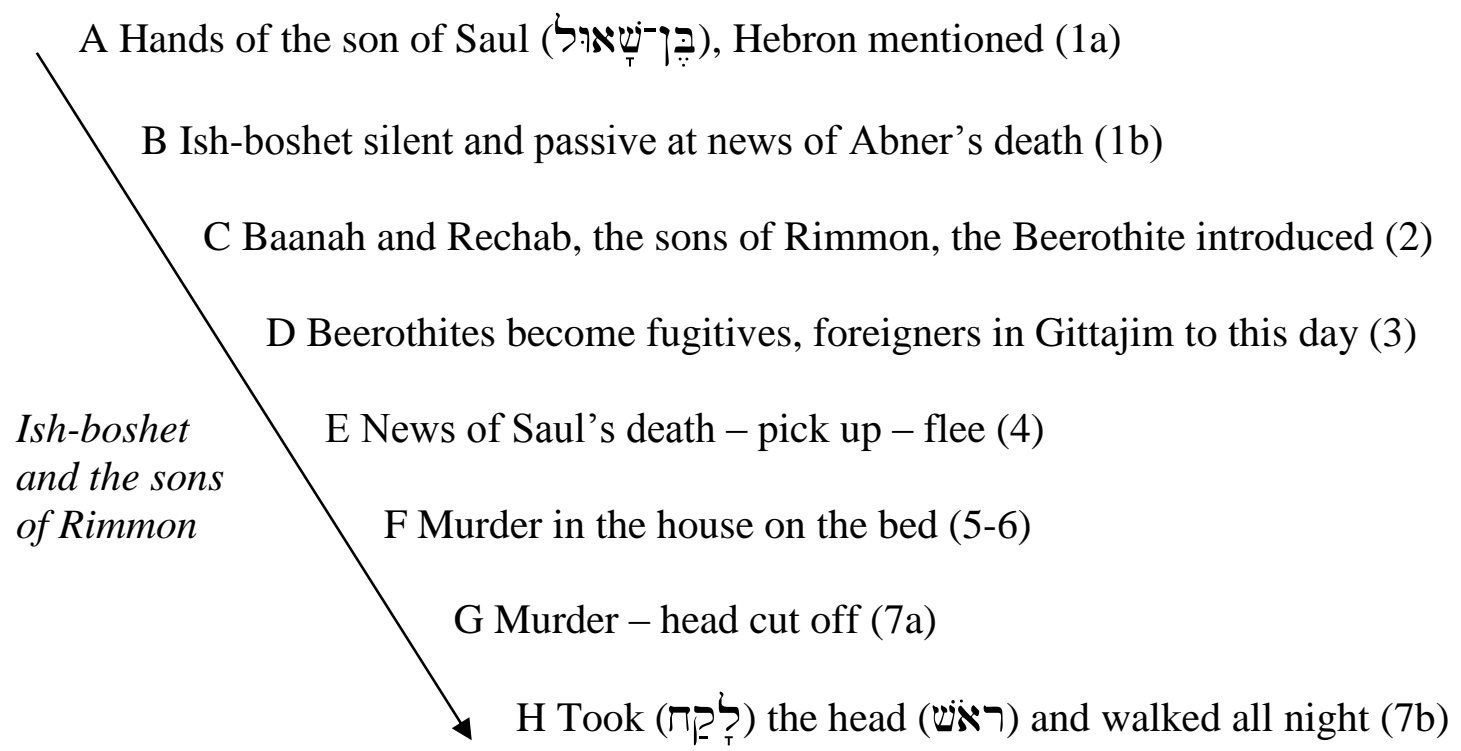




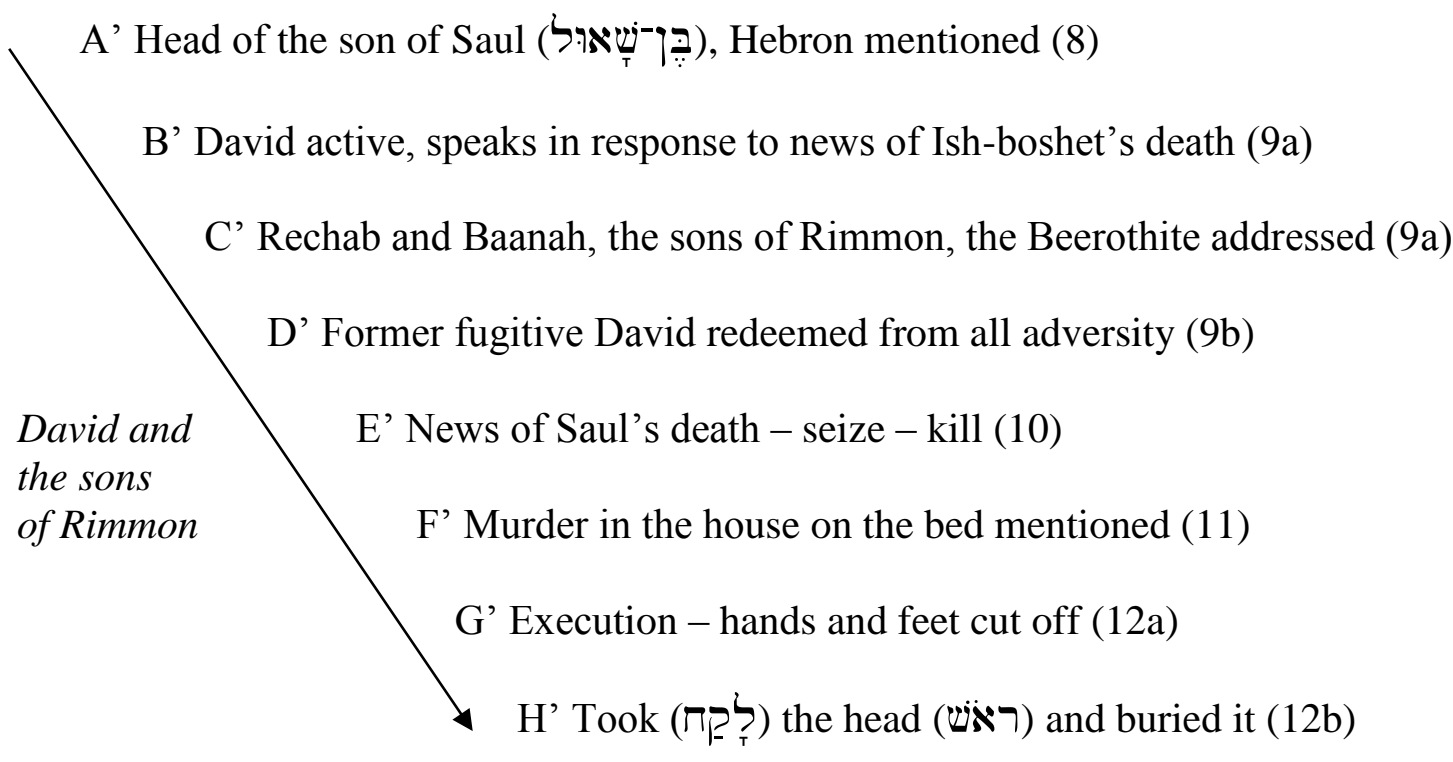

At least four significant aspects of David's kingship are highlighted by these structures:

1. Sovereignty and strength. The second and third structures both underscore David's sovereignty and strength. Unlike the weak and fearful Ish-boshet who remains passive when confronted with Abner's death, David actively responds to the news of Ishboshet's death and has the murderers executed. As the chiastic structure shows, his response marks the turning point of the story.

2. Justice. In particular the parallel panel structure highlights the justice of David's verdict. As the parallel elements F and F' show, those who murdered Ish-boshet and mutilated his body are killed and their bodies are mutilated. The parallel elements A and $A^{\prime}$ in the chiastic structure further emphasize the reversal of fates in that those who sought to cut off the house of Saul whose only surviving members are weak in hands and feet are in the end themselves cut off and left without hands and feet.

3. Respect and kindness toward others. The parallel panel structure also 
highlights David's respectful treatment of Ish-boshet even after the latter's death. While the sons of Rimmon violate Ish-boshet's corpse by cutting off his head and taking it to David in hopes of gaining a reward, David ends the dishonorable treatment of Ishboshet's head by ensuring that it receives a proper burial.

4. Faith in $Y H W H$. The statements of the sons of Rimmon and David at the center of the chiastic structure reveal two contrasting attitudes towards YHWH and his work of deliverance. While Rechab and Baanah selfishly presume that they must act on YHWH's behalf to bring deliverance to David, David's statement reveals that YHWH has acted on David's behalf in the past and can therefore be trusted to deliver him in the present and the future as well.

\section{Close Reading}

It is with a sense of foreboding that the reader approaches the episode in 2 Sam 4 given the developments in the previous chapter as well as David's concluding call for divine vengeance. How will the story continue? Will YHWH indeed repay those who do evil according to their wickedness and if so, how will he do it, how quickly will this happen, and who will be at the receiving end of his vengeance? And: what does Abner's death mean for Ish-boshet's kingship and for the efforts to unite all Israel under David's leadership? Will there be more war between brothers or will peace prevail at last?

\section{Verses 1-4}

Verse 1

At least a partial answer to these questions is already provided in the opening verse of the narrative. Three of the four main actors of the previous narrative were 
mentioned in David's closing statement to his servants in 3:38-39; now the fourth makes

his appearance in 4:1. As in 3:7 and 11 his name is omitted and he is simply referred to as "the son of Saul."5 From the very beginning of the literary unit, the expression brings Saul and the question whether his kingship will continue or not back into the reader's focus, all the more so since the last time Ish-boshet was designated in this way was in the context of the highly significant transfer of Michal in 3:14-16 that symbolized the gift of the kingdom to David. ${ }^{6}$

The wording of the opening phrase once again invites a comparison with David,

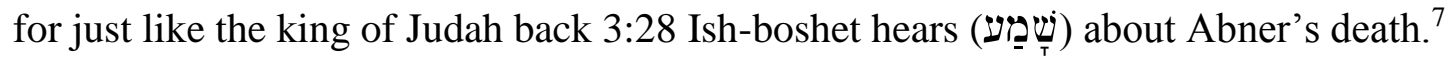
But while David immediately speaks out against the murder and is presented as very active after receiving the news, Ish-boshet stays silent and his hands drop, i.e. he loses all courage and remains completely passive. ${ }^{8}$ While David thus shows himself to be a

\footnotetext{
${ }^{5}$ The omission of Ish-boshet's name is highlighted even further by the fact that the name of Jonathan, the other son of Saul mentioned in 2 Sam 4, is not omitted (see 4:4).

${ }^{6}$ The attentive reader is also reminded of 2 Sam 2:10 where it was stated that Ish-boshet, the son of Saul, was king for two years.

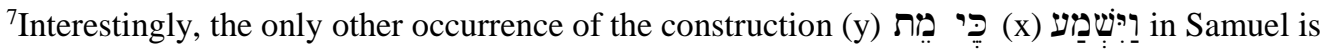
found in 1 Sam 25:39 where David hears that Nabal is dead. The parallel reinforces the connection between Nabal and Abner already noted above, showing that Abner is indeed a fool, as well as the contrast between the active, confident David who praises YHWH and the passive, fearful Ish-boshet who does not utter a single word.

${ }^{8}$ Youngblood, "1 \& 2 Samuel," 843. The idiomatic expression ${ }_{T}$ ידריד discouragement or despair (Robin Wakely, "רפה," NIDOTTE 3:1181-82; K.M. Beyse, "רפרפ," TDOT 13:617). It is used in 2 Sam 17:2 by Absalom to describe David's state of exhaustion and discouragement after his flight from Jerusalem that Absalom seeks to take advantage of as well as in Isaiah and Jeremiah to describe "the nervous collapse and physical paralysis induced by the proximity of an enemy (Jer 6:24; 50:43) or by the approaching day of Yahweh (Isa 13:7; Eze 7:17; 21:7[12])" (Wakely, 1182). Its occurrence in 2 Sam 4:1 is significant, for it not only underscores Ish-boshet's weakness, but also sets him in contrast to David through whose strong hand YHWH will save Israel (3:18), as well as to Abner who wanted to bring all Israel to David with his strong hand (3:12) and to the men of Jabesh-Gilead whom David encourages to have strong hands after the death of Saul (2:7). It does not appear accidental that
} 
capable leader who gains the favor of all the people (כָל לדיהעז $)$, Ish-boshet once more demonstrates a complete lack of leadership. In light of this, it is not surprising that all

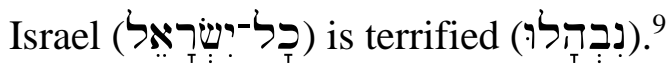

Verse 2

Yet all may not be lost for the son of Saul. He may not be much of a man and he may not have two wives like David, but according to v. 2 he does have two men who are introduced as sons of Rimmon, the Beerothite. Their importance is emphasized right from the start, not only by the syntax of the opening line in v. 2 but also by the amount of information provided about them in vv. 2-3. Both their names as well as the fact that they

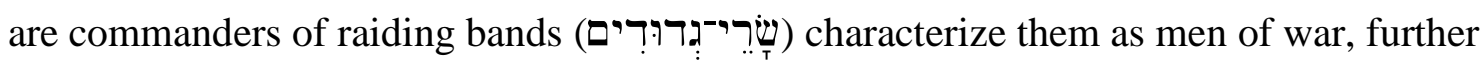
highlighting the contrast to the timid Ish-boshet. ${ }^{10}$ The information about their position is

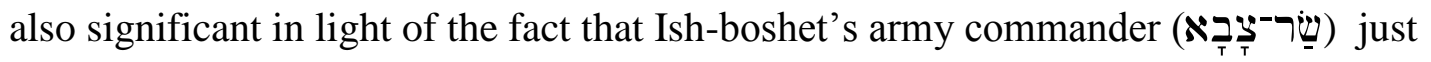
died, raising the question whether one or both of these commanders will take Abner's place and help to secure Ish-boshet's kingship, all the more so since they are explicitly introduced as fellow Benjaminites.

together these three verses once more remind the attentive reader of the transfer of the kingdom to David and thus hint at the end of Saul's kingship. This is highlighted even more by the fact that the last previous occurrence of the verb רפָד Tas in 1 Sam 15:16 in the context of Saul's disobedience which led to the pronouncement that the kingdom would be taken away from him and given to another (1 Sam 15:28).

${ }^{9}$ In the niphal, the verb בָּה implies extreme emotions of horror and despair (cf. Gen 45:3; Judg 20:41; Ps 6:3-4; Isa 21:3; Jer 51:32). As Auld correctly notes, the only other time the term occurs in 1 and 2 Samuel is in 1 Sam 28:21 where Saul is terrified (בָהָל) after "Samuel's" announcement that Israel will be defeated by the Philistines and Saul and his sons will die the next day. (Auld, I \& II Samuel, 389) Will Saul's son now share his father's fate? or "horseman."

${ }^{10}$ The name "Baanah" could mean "son of affliction," while "Rechab" may mean "chariot driver" 
Verse 3

While all of this sounds rather encouraging from Ish-boshet's perspective, it is precisely the verbal link to Abner that should give the attentive reader pause, considering the general's attitude toward the son of Saul in the previous chapter. Could it be that, just like Abner, the sons of Rimmon are opportunists who are driven not by loyalty to their king but by selfish ambition and will therefore not hesitate to switch their allegiance to David if such a move promises to be to their own advantage? A further hint pointing in this direction is found in v. 3, where the Beerothites are described as the young Amalekite in 2 Sam 1 who claimed to have killed Saul and told David that he was the son of a 2 (2 Sam 1:13). Moreover, the fact that the two men are both sons of

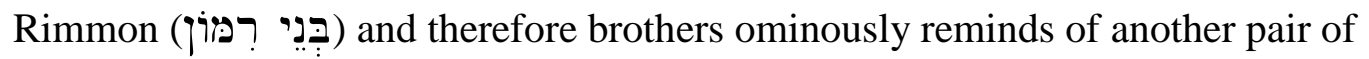

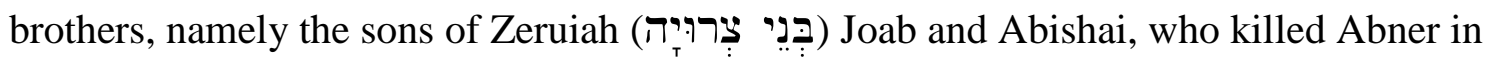
the previous chapter (2 Sam 3:30). ${ }^{11}$ Given that those men were too difficult for David (2 Sam 3:39), how will the weak Ish-boshet fare with these men?

Verse 4

Interestingly, the answer is delayed by a parenthesis in v. 4 that at first glance seems out of place but upon closer examination turns out to be highly significant. Just as the reader expects the story to finally get underway, the author inserts a note about the

\footnotetext{
${ }^{11}$ Alter, The David Story, 217. A further connection to Joab is provided by the term å: in v. 2 which last appeared in 3:22 where the servants of David and Joab came from a raid (å: Thus, "[Baanah and Rechab's] responsibilities...in Ish-Bosheth's army probably were identical to that of Joab's in David's army..." (Bergen, 1,2 Samuel, 315; see also Auld, I \& II Samuel, 389). 
already deceased Jonathan and his crippled son. The fact that Jonathan is explicitly designated as not only further highlights the important question what will become of Saul's kingship but also identifies him as the brother of Ish-boshet who is designated in the same way in vv. 1 and 2. Thus there are now two pairs of brothers, with one pair (the sons of Saul) framing the other (the sons of Rimmon). ${ }^{12}$ A comparison of the two pairs once more emphasizes the weakness of the house of Saul, for while the sons of Rimmon are introduced as men of war, one son of Saul is afraid and the other is already dead as the reader is reminded later in v. 4.

The weakness of Saul's family and its unfitness to rule are further underscored by the information that is now revealed to the reader, namely that the only other direct male descendant of Saul besides Ish-boshet who is still alive at this point is a crippled child and thus "not a viable candidate for the throne." 13 The fact that Ish-boshet has weak hands is already bad enough, yet the only other alternative from the house of Saul is a

\footnotetext{
${ }^{12}$ This spatial separation of Ish-boshet and Jonathan may well have a deeper significance. While the sons of Rimmon always appear side by side throughout the narrative, reflecting the complete unity in both thought and deed that exists between them, the textual distance between Ish-boshet and Jonathan is a subtle reminder how different these brothers are. Whereas Jonathan is an active and courageous individual who dies on the battlefield, Ish-boshet is passive and afraid and is killed while sleeping in his own house. Furthermore, Jonathan has a son, while Ish-boshet appears to be childless. Even more important, however, is the fact that in contrast to Ish-boshet Jonathan does not seek the throne for himself but instead acknowledges David as the divinely chosen king and humbly asks him to show his house (1 Sam 20:14-15). Thus the appearance of Jonathan at this point of the narrative also seems to provide a subtle reminder how the war between brothers could have been avoided and what steps Ishboshet could have taken even at this point to end the conflict peacefully.

${ }^{13}$ Smith, A Critical and Exegetical Commentary, 368. See also Leithart, A Son to Me, 197; Youngblood, "1 \& 2 Samuel," 844; Firth, 1 \& 2 Samuel, 356f.; Tushima, Fate of Saul's Progeny, 150; Campbell, 2 Samuel, 48. Given that David reigned seven and a half years in Hebron (2 Sam 2:11), Mephibosheth would have been at most twelve years old at this point.
} 
child with weak feet. ${ }^{14}$ The weakness of this child is highlighted even more through the contrast to the sons of Rimmon, the only other individuals in the passage who are explicitly introduced by name and belong to a group that had to flee as well (vv. 2-3). ${ }^{15}$ Jonathan may have a son, but he is a crippled child. Ish-boshet, on the other hand, has not just one but two men of war, who are most likely in the prime of life. Thus, the insertion of v. 4 not only emphasizes the weakness of the house of Saul once again, but also draws attention to the apparent superiority of the sons of Rimmon over Mephibosheth. Clearly, it seems, if there is anything that can give the house of Saul hope in this difficult situation it is the fact that Ish-boshet has two warriors like these in his ranks.

Yet a closer look provides another perspective. As already noted, for example, the sons of Rimmon must be viewed with a certain suspicion, given the parallels to Abner and the sons of Zeruiah mentioned above. Interestingly, Mephibosheth is also connected

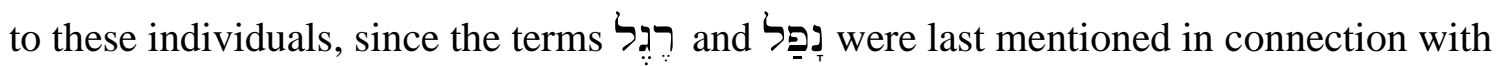
Asahel $\left(2\right.$ Sam 2:18, 23) and Abner (2 Sam 3:34). ${ }^{16}$ Significantly, however, the verbal links in this case immediately highlight the differences between Mephibosheth and the two others. Once more the child's weakness is emphasized, for in contrast to the swiftfooted Asahel (2 Sam 2:18) and Abner, whose feet are not bound (2 Sam 3:34), he is lame. Yet it is precisely his lameness which also distinguishes him from them in a

\footnotetext{
${ }^{14}$ The unfortunate way in which Mephibosheth became crippled (which is explicitly mentioned) further highlights the incapability of the house of Saul. Even the flight of a male descendant and possible heir to the throne ends in a tragedy that basically prevents him from ever becoming king.

${ }^{15}$ Interestingly, both Mephibosheth and the Beerothites also benefit from a covenant which guarantees that they will not be killed (Josh 9:15, 17; 1 Sam 20:14-17).

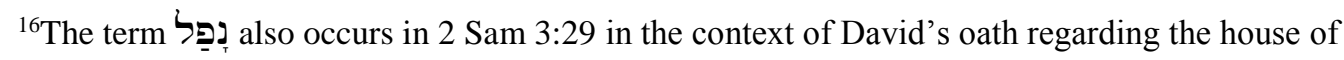
Joab.
} 
positive way, for while they fall and die, he falls and survives. Even though he is crippled, Mephibosheth thus becomes a sign of life and hope in the midst of death and despair. ${ }^{17}$

Further support for this view comes from the fact that Mephibosheth is the son of Jonathan and therefore a direct benefactor of the covenant his father made with David in which the latter promised to show חֶֶ to Jonathan and his house (1 Sam 20:14-17). By mentioning Jonathan's son the insertion in v. 4 thus also serves as a reminder of both David's attitude toward Jonathan's family and the rest of Saul's house (1 Sam 24:22-23), reaffirming that he will not take the kingship by force, as well as of Jonathan's willingness to acknowledge David as the divinely chosen successor of Saul. ${ }^{18}$ What makes this reminder particularly relevant for the present narrative is the fact that the last time Jonathan was mentioned prior to 2 Sam 4:4 David addressed him as "my brother" (2 Sam 1:26). Hence, the unexpected mention of Jonathan reminds the attentive reader of a third pair of brothers that appears to function as a foil for the sons of Saul and especially for the sons of Rimmon, for while the latter are united by the selfish desire for recognition and reward which will lead them to seek to wipe out the house of Saul, David and Jonathan are united by unselfish חֶֶ that prompts Jonathan to humbly recognize David's divine election and David to show mercy to the house of Saul. Thus, it is not the sons of Rimmon but rather the attitude and character of Jonathan and David and the

\footnotetext{
${ }^{17}$ This would be even more the case if Mephiboshet's name indeed means "one who scatters or disperses shame" as Driver suggests. (See Driver, Notes on the Hebrew Text, 254) As Leithart notes, the exact meaning of the name is uncertain. It could also mean "from the mouth of shame." (Leithart, A Son to Me, 229)
}

${ }^{18}$ Brueggemann, First and Second Samuel, 234; Birch, "First and Second Books of Samuel," 1230. 
covenant they made which give hope to the house of Saul and set an example for the brothers from Judah and Israel how their conflict may be settled peacefully.

\section{Verses 5-7}

Verse 5

Beginning in v. 5, the narrative switches back to the sons of Rimmon, who are once more explicitly identified as Beerothites. On the one hand, the repetition of this detail again raises the possibility that these men might indeed be able to help Ish-boshet and the Benjaminites, since the reference to Beeroth is a reminder that these brothers are the descendants of a group who found a way to ensure their survival when their existence was threatened (see Josh 9). On the other hand, however, the association of the sons of Rimmon with the crafty Gibeonites (Josh 9:27) does not make them appear particularly trustworthy. The reader is thus filled with a certain sense of foreboding as the two brothers set out in v. 5a.

The duo's destination is the house of Ish-boshet where they arrive about the heat of the day (חם הַיוֹם) Just as Saul's son is about to be killed, effectively ending the reign of his house for good, the explicit reference to the time of day reminds of the glorious beginning of Saul's kingship, when Israelites fought for instead of against their

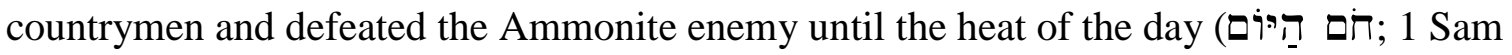
$11: 11) .{ }^{19}$ In stark and tragic contrast the hour of life for the Jabesh-Gileadites now becomes the hour of death for Ish-boshet, further emphasizing the difference between

\footnotetext{
${ }^{19}$ Note that 1 Sam 11:11 and 2 Sam 4:5 are the only places in $1-2$ Samuel where this particular expression occurs.
} 
them and him. Fittingly, Ish-boshet is already in a horizontal position, peacefully taking his midday nap, even as his murderers are approaching. The image of the sleeping king once more underscores his passivity and weakness. ${ }^{20}$ In addition to being silent, he has now become completely inactive as he sleeps in the very moment his kingship is in greatest danger.

The fact that king Ish-boshet is sleeping while two men approach his resting place is also significant because it once more reminds of 1 Samuel 26 where the term שָָׁ last appeared (1 Sam 26:5, 7). There David had a chance to kill the sleeping Saul but refused to do so. The contrast to 2 Sam 4 once again highlights David's great respect for Saul and his refusal to take the throne by force. Ironically, it is precisely this attitude on the part of David which the sons of Rimmon fail to take into account as they kill Ish-boshet and then foolishly present his head to David. Instead of following the example of David, they exhibit the attitude of Abishai, the son of Zeruiah, who wanted to kill Saul (1 Sam 26:8). Yet while Saul was actively pursuing David and was surrounded by three thousand armed men, Ish-boshet is simply taking a nap and in a much more vulnerable position than Saul since he seems to be all alone without anyone to protect him. These contrasts not only further emphasize Ish-boshet's weakness but also highlight the perfidious and cowardly nature of Rechab and Baanah's deed.

${ }^{20}$ Cartledge, 1 \& 2 Samuel, 404. 
Verse 6

Having arrived at the sleeping king's house, the sons of Rimmon seem to be able to enter and proceed to the middle of the house unhindered. The word ominous ring to it since the term last appeared in connection with the deaths of Saul and his sons, who died in the midst of battle (2 Sam 1:25) and Abner, who was killed in the midst of the gate (2 Sam 3:27). At the same time the expression עַרדת reming of 1 Samuel 18 where an evil spirit comes upon Saul and he prophesies in the midst of the

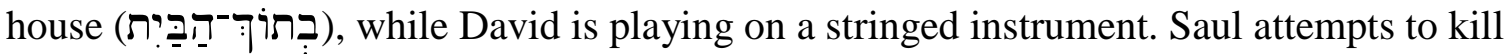
David with a spear, but David evades him twice (1 Sam 18:10-11). In the following chapter Saul tries to arrest David in his house, but again David is able to escape due to the help of his wife who lets him down through the window and then places the teraphim in David's bed (1 Sam 19:11-13). The differences between these scenes and the one in 2 Sam 4:5-7 once again highlight not only David's attitude toward Saul but also his superiority over Ish-boshet, for while the latter is killed on his bed (פְ⿱宀⿴囗十)) in the midst of his house (2 Sam 4:7), David survives an attack on his life in the midst of Saul's house and is able to escape from his own house, causing his pursuers to find only an idol and some goats' hair in his bed (

No wife is at hand to help Ish-boshet, however, as the sons of Rimmon come all the way into his bedroom and strike him in the belly. Any hopes that these commanders might come to the rescue of Ish-boshet and his kingship are now forcefully shattered. The brothers come not to save but to kill. Both the phrase well as a 
sudden reappearance of the term אָ in the final line of v. 6 connect their deed with the killings of Asahel and Abner in the previous chapters, once more associating the two brothers especially with the two sons of Zeruiah Joab and Abishai who murdered Abner by striking him in the belly $(3: 27,30) .{ }^{21}$ Even in death, the son of Saul thus remains connected to Abner as he is killed in the same way as his former general. ${ }^{22}$

Verse 7

While v. 6 provides only a general statement about the murder, more details are revealed in v. 7. At the beginning of the verse the reader is reminded that Ish-boshet is taking a nap when the murderers enter the house. The repetition of this detail not only once more "underlines the scurrilousness of the act of assassination," but also further highlights the king's passivity as well as the ignominious way in which his life and his kingship end. ${ }^{23}$ Rather than heroically dying on the battlefield, he is killed by his own commanders while sleeping on his bed in his bedroom. Yet as is also revealed in this verse, he is not only killed, but - like his father Saul - also beheaded. The one whose hands dropped at the beginning of the narrative has now lost his head, signifying that his headship and therefore also the headship of the house of Saul over Israel has come to an end. $^{24}$

${ }^{21}$ Newkirk, Just Deceivers, 100.

${ }^{22} \mathrm{~A}$ further parallel between Abner and Ish-boshet is that both men lie on a פִָּּה (2 Sam 3:31; 4:7)

${ }^{23}$ Alter, The David Story, 218. See also Smith, A Critical and Exegetical Commentary, 369.

${ }^{24}$ Leithart, A Son to Me, 197; Fokkelman, Throne and City, 129. It does not seem accidental that the only time the combination סראש + occurs previously in Samuel is in 1 Sam 17:46 where David 
Yet the murderers are not satisfied with simply eliminating Ish-boshet. Having

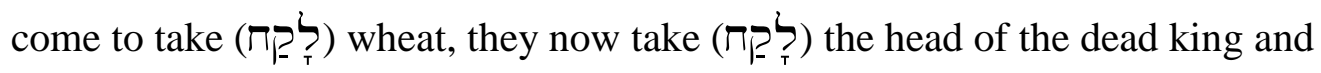
immediately set out for Hebron. ${ }^{25}$ Fittingly, the lawless brothers travel in darkness as they walk all night through the עִּרָה , a largely arid and desolate region where Israel camped prior to entering the land and was reminded of the law (Deut 1:1). עירד

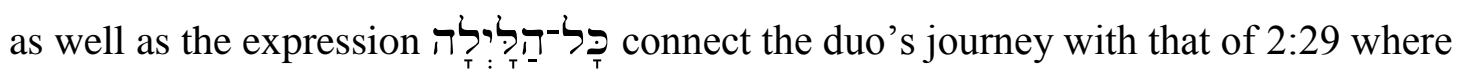
Abner and his men take the same route after their defeat at Gibeon. Yet while the latter travel toward Mahanaim, underscoring the continued division of Israel into two camps, the sons of Rimmon are headed in the opposite direction in order to announce to David that Ish-boshet is dead, meaning that the way is now open for Israel to be reunited. Though this contrast at first glance seems to cast the brothers' mission in a favorable light, a second contrast once more reveals that just the opposite is the case, for as

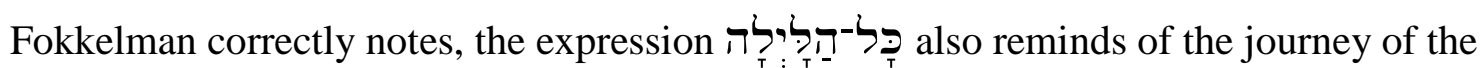

announces to Goliath that he will strike him and remove his head from him. Just as the passive Ish-boshet is killed by fellow Israelites, the attentive reader is thus reminded of the very active David who fought against Israel's enemies and cut off Goliath's head rather than having his own head removed. Thus the contrast between the two kings once again becomes evident. At the same time, the allusion also highlights the contrast between David and the sons of Rimmon. While he bravely goes into battle all by himself against a fully armed heathen giant who is ready to fight, the two (!) brothers treacherously kill their own defenseless king while he is sleeping in his own house.

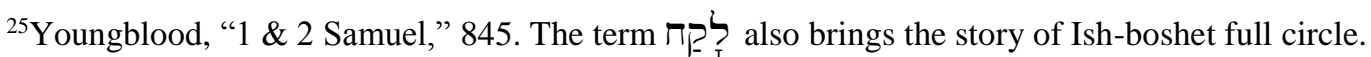
When he first appeared on the scene in 2 Sam 2:8 he was taken (לק לקח) by Abner and brought over to Mahanaim. As he leaves the stage in 2 Sam 4:7, his head is taken (לקָ (לקח) away from Mahanaim. Thus the term לZT $_{T}$ provides a frame around the story of Ish-boshet that further highlights his weakness. From the beginning of his reign to the very end, indeed, even in his death he is used by others for their own agenda.

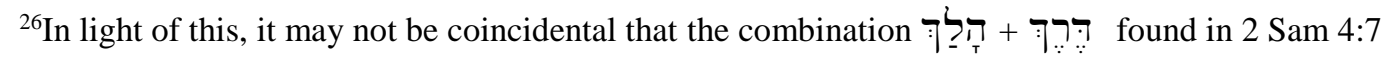
is often used in Deuteronomy in connection with divine appeals to Israel to keep the law (see e.g. Deut $5: 33 ; 8: 6 ; 10: 12 ; 11: 22 ; 13: 6$; etc.). 
men of Jabesh-Gilead (1 Sam 31:12), who "with their loyalty to Saul, and their courageous swift journey through enemy lines, ... are, of course, the opposite pole of the treacherous Benjaminite duo and their cowardly attack." ${ }^{27}$ Considering how favorably David responded to what they did for Saul and his sons, this contrast does not bode well for the brothers who are about to appear before this very David.

\section{Verses 8-12}

Verse 8

Having just escaped the royal residence of one king, the two assassins make their way to that of the other, bringing the head of Ish-boshet to David at Hebron. The message is clear: "the gift of Ish-boshet's head is at the same time the gift of the kingdom." 28 Thus it now becomes apparent that this is yet another attempt to make David king over a united Israel through human power and scheming. In light of this, it is not surprising that the brothers' escape (ריִירכו) at the end of v. 7 as well as the sequence of bringing (hiphil of בוא) Something and appearing before David at Hebron bring to mind the previous chapter where Abner sought to turn all Israel to David (3:12) and was to bring (hiphil of בואי) Michal as a symbol of the transfer of the kingdom (3:13) when he came to Hebron. After his meeting with David he went away (פרי? had just brought (hiphil of בּוא) much spoil (3:22), to appear before the king to demand

\footnotetext{
${ }^{27}$ Fokkelman, Throne and City, 129.

${ }^{28}$ Gunn, „David and the Gift of the Kingdom,” 197.
} 


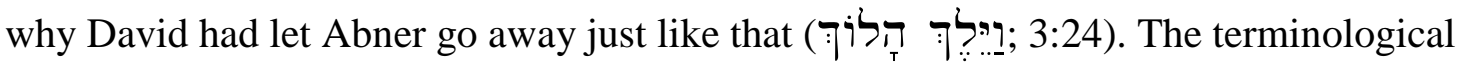
parallels once more connect the sons of Rimmon with both Abner and Joab. Like the former, they attempt to bring David the kingdom, yet in much more radical and violent fashion than the general and without David's knowledge. Like Joab, they seek to execute justice themselves, raising the question how David will react this time, or, as Fokkelman puts it: "Can such an easy getaway as theirs actually be brought off? Are they going to succeed completely?"29

They themselves certainly seem to believe so as they boldly launch into a short speech addressed to "the king." That David is referred to as "king" at this particular point in the narrative is significant for a number of reasons. For one thing, it further highlights the point of view of the sons of Rimmon who have just murdered the king of Israel and have brought his head to Hebron as a symbol that the kingship over Israel has now passed to David - thanks to their help, of course. To them David is "the king" as they explicitly acknowledge in their speech. Yet the very thing they affirm has a threatening side to it as well, for by recognizing David as king, the two murderers also unwittingly acknowledge that they are now in the presence of one who has power and authority to call them to account for their heinous deed. While they expect David to rejoice over the death of Ishboshet, this is far from certain, especially since the last time David was called "king" was in the context of Abner's funeral (2 Sam 3:31-39) where David not only mourned deeply over a member of the house of Saul who had been treacherously killed by two brothers,

${ }^{29}$ Fokkelman, Throne and City, 129. 
but also explicitly condemned the murder. It is this king Baanah and Rechab are about to address.

Their speech consists of just two sentences in which they seek to justify their deed. They begin by reminding David who they have eliminated, namely "Ish-boshet, the son of Saul, your enemy who sought your life." Though "the apposition refers to Saul, ..., and not to Ishbosheth, ... the gentlemen make the connection so easily that they do, in fact, manage to suggest that Ishbosheth has been a dangerous enemy of David." ${ }^{30}$ Yet there is no evidence that Ish-boshet ever acted like his father toward David. Rather it is the sons of Rimmon who have acted like Saul by seeking the life of a fellow Israelite. Thus, they are guilty of the very thing they accuse Saul (and indirectly Ish-boshet) of.

In the second part of their speech the brothers seek to present themselves as merely executing the will of YHWH. Through their deed YHWH has been able to avenge David of Saul and his descendants they claim. This highly presumptuous attitude of acting for YHWH without any evidence of a divine order to do so once more associates the sons of Rimmon with Abner who displayed a similar mindset in his conversation with Ish-boshet in 2 Sam 3:9-10. ${ }^{31}$ At the same time, the attitude of the brothers and the words they use strongly remind of the speech of David's men in 1 Sam 24:5 and that of Abishai in 1 Sam 26:8. In both cases David had the chance to kill Saul, but adamantly refused to do so. ${ }^{32}$ Furthermore, the mention of Saul's seed (זרע) in 2 Sam 4:8 brings to mind

\footnotetext{
${ }^{30}$ Fokkelman, Throne and City, 130. See also Firth, $1 \& 2$ Samuel, 357-58.

${ }^{31}$ The connection to Abner is further highlighted by the fact that both the general as well as the sons of Rimmon address David as "my lord, the king" (2 Sam 3:21; 4:8).

${ }^{32}$ Fokkelman, Throne and City, 130.
} 
David's oath to Saul that he would not cut off his seed (זרבע..) after him (1 Sam 24:22-23).

The verbal link once more emphasizes David's attitude toward Saul and his house and his promise not to harm Saul's descendants. Even before the sons of Rimmon have ended their speech, the attentive reader thus suspects that David will not be impressed by it.

\section{Verse 9}

That this is indeed the case becomes evident rather quickly in David's response, which is preceded by a fairly lengthy introduction in v. 9a in which the names of the two men, their relationship to each other as well as their origin are once more noted. The detailed description further strengthens the impression that this is a court scene in which a case has been presented to the king, who serves as the highest judge and will now declare the verdict. ${ }^{33}$ In light of this, it is significant that the introduction to David's answer points back both to the murder scene where the same information was given in vv. 5 and 6 as well as to the beginning of the story where the relationship of the two men to Ishboshet was described in v. 2. It is these men who have murdered their own leader on his bed and were able to escape without being called to account for their deed whom the king will now address. Thus "the completeness of the description... is ominous for the two men." 34

Just as David had responded to the speeches of his men in 1 Sam 24 and of Abishai in 1 Sam 26, so he now responds to the speech of the sons of Rimmon, namely

\footnotetext{
${ }^{33}$ Fokkelman, Throne and City, 131: "The introduction... has the air of being the official minutes. Once again the narrator is busy recording information, like the clerk of the court; information which will shortly be required in a court case."

${ }^{34}$ Fokkelman, Throne and City, 131.
} 
with an oath, giving additional weight to his words. ${ }^{35}$ Whereas they had begun their speech with a proclamation of death, he begins with a proclamation of life: YHWH lives! In the midst of bloodshed and death brought about by those who act as if YHWH is dead David thus proclaims the simple, yet profound truth that YHWH is alive. This truth is the foundation upon which his whole speech is built and becomes the basis for the verdict David is about to issue.

The reason David is so confident about this truth is because he has experienced it. YHWH has proven that he is alive by redeeming David's soul (גֶֶֶ) from all distress. This declaration is David's counter to Baanah and Rechab's statement in v. 8 that Saul

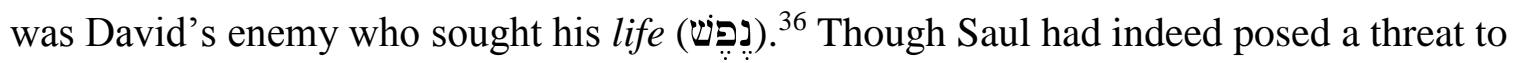
David as the Beerothite brothers reminded him, David's answer suggests that there was no need to act on behalf of YHWH and exact revenge upon the house of Saul, for YHWH is alive and therefore perfectly capable of acting on behalf of David without the brothers' help as he had demonstrated by saving him from all distress, including the threat posed by Saul and his house. Thus, David makes it clear that he is "already under the protection of the Lord and does not need any henchmen." ${ }^{37}$ His kingship will be based on trust in the Lord and his deliverance rather than on revenge presumptuously exacted in the name of the Lord.

\footnotetext{
${ }^{35}$ Fokkelman, Throne and City, 130.

${ }^{36}$ Gordon, I \& II Samuel, 223.

${ }^{37}$ Fokkelman, Throne and City, 132. See also Cartledge, 1 \& 2 Samuel, 404. 
Verse 10

As both the visitors and the reader are reminded in v. 10 this is not a new attitude that David adopted only recently. It was already on display in the episode recorded in 2 Sam 1, for example, which David now makes reference to in his speech. The reason he does so becomes evident rather quickly. By quoting the Amalekite as saying: "Behold,

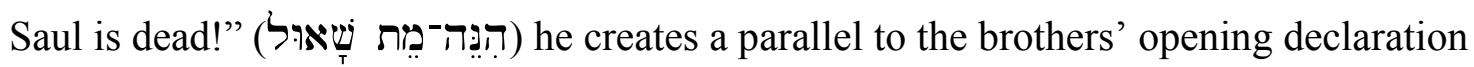

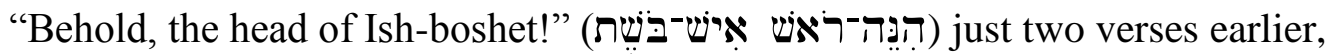
suggesting that "for David, the death of Ishbosheth is, in one way or another, a counterpart of the death of Saul." 38 The connection David thus establishes between the Amalekite and the two Beerothites does not bode well for the latter.

After quoting the Amalekite's words, David provides more insight into the man's mind and motive by stating that he was as a bearer of good news in his eyes. Once again the exact wording is significant, for the addition of the preposition $\underset{?}{9}$ to the participle

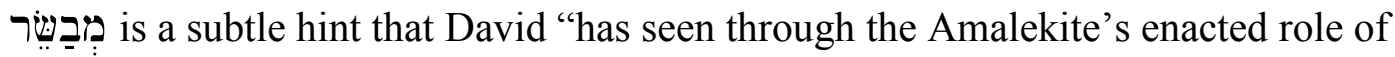
bringer of good news whilst his real objective was the pursuit of gain." ${ }^{39}$ He wanted a reward, which he ironically received, though not in the way he had imagined, for as David reminds the sons of Rimmon he "paid" the messenger by seizing and executing him at Ziklag. ${ }^{40}$ As the murderous duo is about to discover they will share the same fate.

\footnotetext{
${ }^{38}$ Fokkelman, Throne and City, 133.

${ }^{39}$ Fokkelman, Throne and City, 134. See also Youngblood, "1 \& 2 Samuel," 846 and Firth, 1 \& 2 Samuel, 358.
}

${ }^{40}$ Firth, 1 \& 2 Samuel, 358. 
Verse 11

Having cited the case of the Amalekite as a judicial precedent, David now brings his speech to its logical conclusion. If he had executed the Amalekite, how much more must he do the same to the sons of Rimmon who committed an even worse crime, for in contrast to the Amalekite who only claimed to have killed the rebellious Saul on the battlefield at his own request, they actually murdered the innocent Ish-boshet in his house on his bed. ${ }^{41}$ Though they claimed to have acted on YHWH's behalf, David is not fooled by their pious words but clearly states their true identity. They are not agents of YHWH but wicked men (plural) who killed a righteous man (singular). Thus not only the true nature of their deed and the justice of the verdict are revealed, but also the true identity of

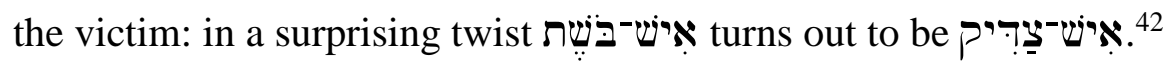

In light of David's assessment in the first half of v. 11, there is only one possible verdict, which the king presents in form of a rhetorical question: "Shall I not now require his blood from your hand and purge you from the land?" As commentators have noted, the language he uses is judicial and reminds of earlier divine regulations regarding murder and capital punishment in Gen 9:5 and Deut 19:13, 19. ${ }^{43}$ The wording of the verdict thus once again highlights both David's faithfulness to the divine law given both to Israel and humanity in general as well as his concern for "indemnifying the community

\footnotetext{
${ }^{41}$ Anderson, 2 Samuel, 71; vom Orde, Das zweite Buch Samuel, 71; Youngblood, "1 \& 2 Samuel," 846; Smith, A Critical and Exegetical Commentary, 370.

${ }^{42}$ As McCarter notes, “in contrast to Saul, Ishbaal is not described as Yahweh's anointed or even as king," suggesting that "his kingship is not recognized by David" and that the "narrator presents David as

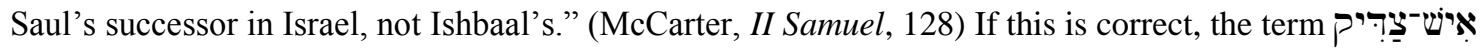
would be a further indirect hint at the weakness and illegitimacy of Ish-boshet's kingship.

${ }^{43}$ Leithart, A Son to Me, 198; Fokkelman, Throne and City, 135.
} 
from [the consequences of] a serious case of bloodguilt." ${ }^{44}$ This is only possible if the

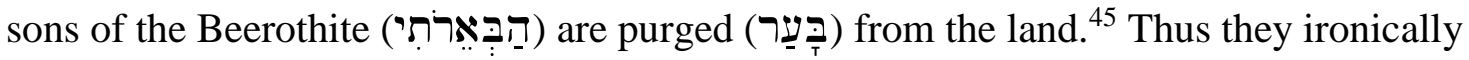
experience the very fate their cunning ancestors managed to avoid.

Verse 12

The sentence is swiftly carried out, demonstrating David's authority and decisiveness which differentiate him from Ish-boshet. Not only are the two murderers executed but their hands and feet are cut off - a fitting punishment for those who took advantage of the weakness of Saul's house, illustrated at the beginning of the narrative through Ish-boshet's sunken hands and Mephibosheths lame feet. ${ }^{46}$ Those who seemed so superior to the two descendants of Saul are now even worse off than they. In addition, the brothers' bodies are hung over the pool of Hebron. ${ }^{47}$ Thus the narrative has come full circle: the controversy which began at a pool back in 2 Sam 2 now ends at another pool. ${ }^{48}$

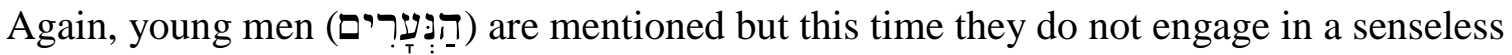
fight against each other but instead obediently follow king David's orders and execute a justified sentence.

\footnotetext{
${ }^{44}$ Fokkelman, Throne and City, 135.

${ }^{45}$ Stefan C. Matzal, “A Wordplay in 2 Samuel 4,” Vetus Testamentum 62 (2012), 462.

${ }^{46}$ Fokkelman, Throne and City, 135.

${ }^{47}$ Since the verb תקלד lacks an object in the MT, it remains unclear whether the limbs or the bodies were hung up. The latter option, which is preferred by most commentators (see e.g. Youngblood, "1 \& 2 Samuel," 847; Smith, A Critical and Exegetical Commentary, 370; Firth, 1 \& 2 Samuel, 358; Morrison, 2 Samuel, 66; Cartledge, $1 \& 2$ Samuel, 405), seems to fit the context better, since such an act would express what was already implied in the final clause in v. 11, namely that „Recab and Baanah died under a divine curse (cf. Deut 21:22-23).“(Bergen, 1,2 Samuel, 317).
}

${ }^{48}$ Youngblood, “1 \& 2 Samuel,” 847. 
While the murderers are publicly disgraced and exposed to the elements, David shows respect and kindness to their victim by granting the head of Ish-boshet a proper burial in the grave of Abner at Hebron - an act which stands in stark contrast to the treatment of Ishboshet's head by the sons of Rimmon in vv. 7-8. ${ }^{49}$ Thus, the son of Saul is reunited in death with his former general in David's capital city. As Fokkelman aptly notes, "the irony of the situation that both adversaries of the Judean throne are united in the city where the throne of David stands, in an emergency grave, is...almost unbearable." ${ }^{50}$ It is a fitting conclusion to and a final commentary on the story of Abner and Ish-boshet. He who selfishly grasped for power and headship over Israel ends up in a grave with the severed head of the king he installed on his own authority, who even in death is unable to emancipate himself from the man at whose mercy he was in life. ${ }^{51}$

\section{Implications for the Nature of David's Kingship}

The above exegetical analysis further confirms and provides additional insight into a number of significant aspects of David's kingship that were already on display in previous literary units within 2 Sam 2:1-5:5.

\footnotetext{
${ }^{49}$ While the sons of Rimmon take (לקבקז) Ish-boshet's head to present it to David (vv. 7-8), David's young men take (לקָז) Ish-boshet's head to bury it.

${ }^{50}$ Fokkelman, Throne and City, 136.

${ }^{51}$ Note how, as in v. 7, the act of taking (ללקח) Ish-boshet's head reminds of the beginning of the story in 2 Sam 2:8-9, where Abner took (לק לקח) Ish-boshet and made him king (Charles Mabee, "David's Judicial Exoneration," Zeitschrift für die Alttestamentliche Wissenschaft 92 (1980), 105). Though Ishboshet's fortunes are now reversed, one thing has not changed: as in life so in death he is acted on by others and does not even receive a grave of his own. Just before he disappears from the narrative, his weakness and dependency on Abner is thus emphasized one last time.
} 


\section{The Legitimacy of David's Kingship}

Qualified by his character. David's decisive response to the sons of Rimmon once more reveals his character. He will not rejoice over the death of Ish-boshet and use it to his own advantage. Instead he condemns the murderers and has them executed, yet again demonstrating that he will not take the throne by force. This attitude is further emphasized throughout the chapter through allusions to the execution of the Amalekite in 2 Sam 1 as well as to the three narratives in 1 Sam $24-26$ where David refuses to help himself with his own hand and kill Saul/Nabal.

Qualified by his personality. In contrast to the fearful and passive Ish-boshet who does not utter a word in response to Abner's death and is killed by his own generals while taking a nap, David is once more presented as an active individual and a capable leader who immediately and decisively speaks out against Ish-boshet's murder and does not hesitate to bring the murderers to justice.

\section{Foundational Elements of David's Kingship}

Faith in $Y H W H$. The dialogue between David and the sons of Rimmon at the structural center of the narrative further confirms what already became apparent in previous literary units, namely that faith in YHWH and his ability to deliver is an important element of David's kingship. While Rechab and Baanah take matters into their own hands, thus betraying their complete lack of faith in YHWH, the opening statement of David's response reveals a very different attitude. His words suggest that he will continue to wait on YHWH and trust in his deliverance instead of helping himself with his own hand as the two brothers had. 
Discernment. David's response to the sons of Rimmon also reveals his discernment. He is not fooled by the pious front put up by the murderous duo who present themselves as agents of YHWH, but immediately recognizes their true character and their true motive. Like the Amalekite in 2 Sam 1, they are selfish, calculating individuals who did not act on behalf of YHWH but instead were motivated solely by the hope of receiving a reward for their deed. By identifying them as wicked men who killed a righteous man in his house on his bed, David also clearly shows that what they claim to be an act of justice is in reality an act of heinous injustice.

Justice. In contrast to the self-serving and unjustified (in)justice executed by the sons of Rimmon, the justice administered by David is not only completely appropriate and necessary, but also based on the divine law. This is made evident by the structure of the passage as well as by the wording of David's verdict in v. 11 which reminds of the divine regulations regarding murder and capital punishment in Gen 9:5 and Deut 19:13, 19. The justice of David's verdict is further highlighted by the ironic reversal that the very ones who desired to cut off the house of Saul whose only remaining descendants are presented as weak in hands and feet end up being cut off themselves and are left with no hands and feet at all.

Sovereignty and strength. As noted above, both the chiastic structure as well as the parallel panel structure emphasize David's sovereignty and strength. Unlike Ishboshet who remains silent and passive at the news of Abner's death, David presents himself as a sovereign ruler who decisively changes the course of events through his immediate, courageous and articulate response to the news of Ish-boshet's murder. 
Concern for the people. The wording of David's verdict in v. 11 also provides further evidence of his concern for his subjects. As the allusion to Deut 19:13, 19 reveals, the execution of the sons of Rimmon is not only the just punishment for their deed but also a necessary act to ensure the present and future well-being of the nation by protecting the people from the consequences of bloodguilt.

Obedience to the divine law. At the same time, the allusions to Gen 9:5 and Deut 19:13, 19 also reveal David's faithfulness and obedience to the divine law given to Israel and to humanity in general. In contrast to the sons of Rimmon who brazenly break the law while claiming to serve YHWH, David's response in vv. 9-11 demonstrates his commitment to abide by the law of God and make it the foundation of his kingship.

Respect and kindness towards others. David's attitude of respect and kindness towards others, which was already on display in previous literary units, is emphasized again in particular by the parallel panel structure which contrasts David's treatment of Ish-boshet's head with the sons of Rimmon's treatment of the same. While the latter sever the head from the body and misuse it for their own wicked purposes, David shows his respect for Ish-boshet by ensuring that his head is properly buried.

\section{Samuel 5:1-5}

Text

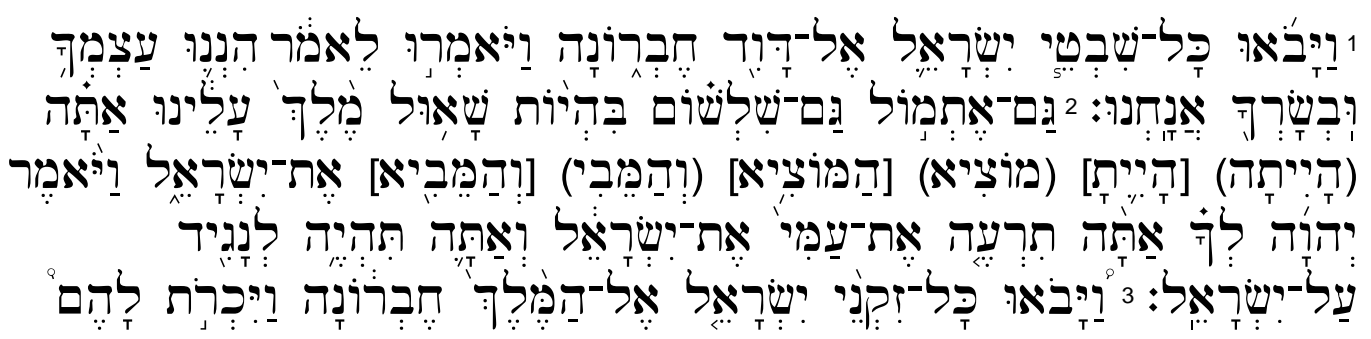




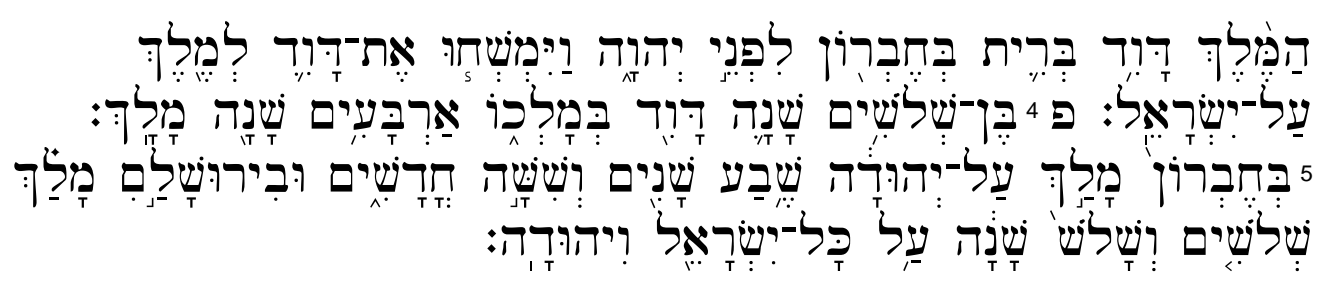

Translation

${ }^{1}$ Then all the tribes of Israel came to David to Hebron and said: Behold, we are your bone and your flesh. ${ }^{2}$ Also heretofore when Saul was king over us, you were the one who led Israel out and brought them in. And the Lord said to you: You shall shepherd my people Israel and you shall be a ruler over Israel.

${ }^{3}$ So all the elders of Israel came to the king to Hebron and king David made a covenant with them in Hebron before the Lord. Then they anointed David king over Israel. ${ }^{4}$ David was thirty years old when he began to reign, and he reigned for forty years. ${ }^{5}$ In Hebron he reigned over Judah seven years and six months, and in Jerusalem he reigned thirty-three years over all Israel and Judah.

Delimitation

As already noted above, the beginning of this literary unit is clearly marked both by the fact that 2 Sam 4:12 forms an inclusio with 4:1 as well as by the appearance of a new group of characters, i.e. the tribes of Israel, in 5:1, whose meeting with David prepares the way for his coronation as king over all Israel in v. 3 . While the starting point of the unit is thus readily identified, the more difficult task is to determine where it ends. Various views are found among commentators. While some like Auld believe the unit ends in v. 3, others extend it as far as v. $12 .{ }^{52}$ Though there are certainly thematic and linguistic connections between the report of David's coronation and the following verses that describe the capture of Jerusalem, the building of David's house and the growth of his family, the geographical move from Hebron to Jerusalem and the introduction of a

${ }^{52}$ Auld, I \& II Samuel, 391; Hertzberg, I \& II Samuel, 266; Vannoy, 1-2 Samuel, 290. 
new group of characters (הַיברים in v. 6 nevertheless suggest that a new unit begins there.

This leaves the statistical note in vv. 4-5 which appears to have a transitional function through the mention of both Hebron and Jerusalem. Nonetheless, a careful textual analysis suggests that the two verses are more closely linked to vv. 1-3 than to the immediately following verses. Not only is there a strong thematic connection, but the

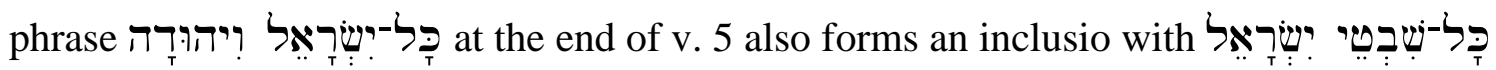
at the beginning of v. 1. Furthermore, in light of the numbers mentioned in vv. 4-5 which are all multiples of 3,4 and 7, it may not be accidental that a number of key words occur 3, 4 or 7 times in vv. $1-5 .^{53}$ Thus it seems best to follow the great majority of commentators and view 5:1-5 as one literary unit. ${ }^{54}$

\section{Structure}

The unit may be divided into three subsections: the meeting of the tribes of Israel with David in vv. 1-2 is followed by the covenant and anointing ceremony between the elders of Israel and David in v. 3 and a concluding statistical note in vv. 4-5. As in the complementary passage in 2 Sam 2:1-11, each of these sections ends with a statement about David's kingship - in this case not over Judah, but over all Israel. ${ }^{55}$ In addition, the first two sections begin with very similar statements about a group of Israelites that

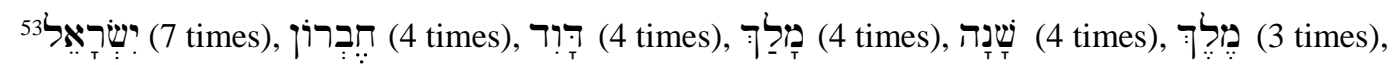

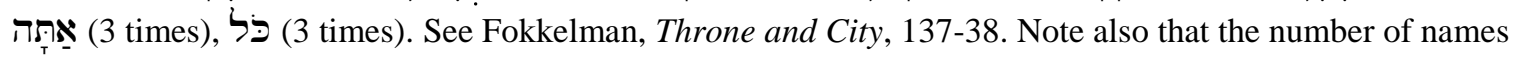
in vv. 1-5 (21) is also a multiple of three.

${ }^{54}$ See e.g. Smith, A Critical and Exegetical Commentary, 371; Bergen, 1,2 Samuel, 318; Morrison, 2 Samuel, 66; Fokkelman, Throne and City, 137; Birch, "First and Second Books of Samuel," 1232.

${ }^{55}$ The complementary nature of the two passages is also made evident by the fact that both end with very similar statistical notes $(2: 10-11 ; 5: 4-5)$. 
comes to David at Hebron (vv. 1a and 3a). As Morrison further suggests, these two sections may be arranged in parallel fashion, with the second section presenting the implementation of what was implicitly proposed in the first:

A. The tribes of Israel come to David at Hebron (5:1a)

B. Israel seeks a covenant with David (5:1b)

C. David should be their shepherd and ruler $(5: 2)$

A'. The elders of Israel come to the king at Hebron (5:3a)

B'. The king makes a covenant with the elders of Israel (5:3b)

$\mathrm{C}^{\prime}$. They anoint David as their king $(5: 3 \mathrm{c})^{56}$

Alternatively, it also seems possible to include vv. 4-5 in element C'. In that case the statistical note in these verses would further demonstrate the fulfillment of the divine promise in v. 2 .

The following aspects of David's kingship are highlighted by the structure:

1. Unity. Elements A and A' emphasize the unity of Israel at the time of David's coronation. All the tribes come to Hebron to express their loyalty to David and their conviction that he should be king over Israel, followed by all the elders who participate in the covenant and anointing ceremony.

2. Covenant. Elements B and B' as well as the placement of the statement that David made a covenant with the elders at the center of the unit highlight the covenantal relationship between king and people as an important aspect of David's

${ }^{56}$ Morrison, 2 Samuel, 66. 
kingship. This covenant is not forced upon the people but is made in response to their statement in v. 1 expressing their desire to be joined to David.

3. David as shepherd and פנזיד over Israel. The nature of David's kingship is

further clarified by the parallel arrangement of elements $C$ and $C$ ' in that the term מקלְּר in

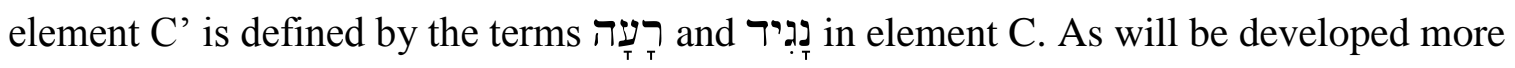
fully below, the structure thus emphasizes that David's kingship is not associated with absolute and arbitrary power but rather with serving and caring for the people as a faithful stewart who has been entrusted with this position by $\mathrm{YHWH}$ and is therefore responsible to him.

\section{Close Reading}

\section{Verses 1-2}

\section{Verse 1}

With both Abner and Ish-boshet dead and buried, the way for David to become king over all Israel seems clear. The only question that remains is how this will come about. In light of this, it is significant that the unit does not begin with any action on David's part but rather with the tribes of Israel in the subject position. Instead of David actively seizing the opportunity and proclaiming himself king, it is the people who take the initiative as they come to David at Hebron. He, on the other hand, does not become active until v. 3, but even this action is simply a response to the implicit request of the tribes and the subsequent approach of the elders. The entire unit is thus characterized by a 
striking passivity on David's part, once more underscoring "the underlying theme that

David did not seek the throne on his own, but was brought to it by Yahweh."57

Just as remarkable as the passivity of David is the unity of people and king that is emphasized throughout the unit. What Abner so confidently promised but failed to achieve, now happens almost effortlessly, it appears, without any human intervention: not just some but all the tribes of Israel come to Hebron. ${ }^{58}$ As Fokkelman notes, their coming (בּו) is reminiscent of the scene in the previous chapter where the sons of Rimmon bring (hiphil of בפוא) the head of Ish-boshet to David at Hebron (4:8). ${ }^{59}$ Like the tribes, the two brothers take the initiative to make David king, yet they do so on their own, by criminal means and in hopes of personal gain. While they proudly present a severed head (causing them to lose their own hands and feet), the tribes humbly acknowledge that they are David's bone and flesh. In contrast to the reign of Abner and Ish-boshet, David's kingship is thus once more associated with unity. He and the people are one body. ${ }^{60}$

${ }^{57}$ Cartledge, $1 \& 2$ Samuel, 409. See also McCarter, II Samuel, 133-34.

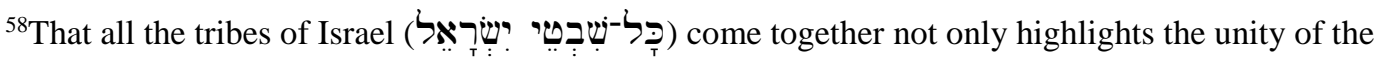
nation that was missing for so long but also reminds of the coronation of Saul back in 1 Sam 10, the only previous place in the Samuel books where the exact same phrase occurs. Furthermore, it does not appear

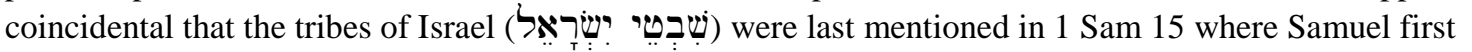

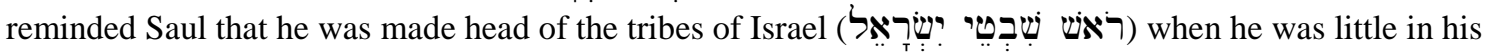
own eyes (v. 17) and then announced to him that because of his lack of faith, the kingship would be taken away from him and given to his neighbor (v. 28). In light of these intertextual connections, the appearance of the tribes of Israel in 2 Sam 5 just after the burial of the head (ראשי) of Ish-boshet, signifying the end of Saul's headship over Israel, appears to be a subtle hint that the transfer announced in 1 Sam 15 is about to become reality and another coronation will take place shortly.

${ }^{59}$ Fokkelman, Throne and City, 138. Note also that both speeches begin with the interjection הִגְ.

${ }^{60} \mathrm{As}$ Fokkelman notes, the idea of unity is emphasized not only by the content but also by the form of the text: "The tribes' speech is alive with pairs. Not only are the halves, the degrees, and the times discussed neatly divided and not only does the 2de pair, qua content and chronology, link up with $2 \mathrm{ab}$, but there are also all kinds of pairs on the level of the choice of words. The most important are the two 
The opening statement of the tribes is significant for other reasons as well. First, the appearance of the term עִֶֶּ just after the burial of Ish-boshet's head provides a link back to the burial of Saul and his sons in 1 Sam 31:13, the last time bones were mentioned in the narrative. ${ }^{61}$ The contrast is once again striking, for while Saul's headless body is burned, leaving only the bones (plural of עִֶֶ) without flesh to be buried, David's "body" is alive and well, consisting not only of bone and flesh, but also of a head, i.e. the king himself, that is connected to the trunk as indicated by the covenant in v. 3 that seals David's headship over the tribes. In this way, the superiority of David's kingship is once more emphasized.

Second, a survey of the previous three occurrences of the combination reveals that this is a technical phrase denoting kinship: in Gen 2:23 Adam refers to the

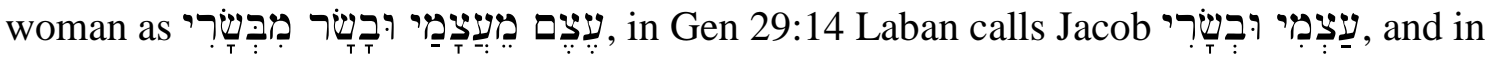
Judg 9:2 Gideon's son Abimelech asks his mother's brothers to remind the citizens of

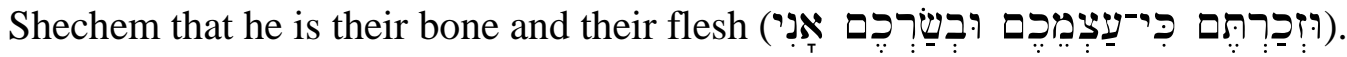
Significantly, in both Gen 29 and Judg 9 the phrase more specifically signifies

merismuses, 'your bone and your flesh', 'yesterday and the day before yesterday', with a double gam, and the double movement of the general in hammosși and hammebì. The mass of pairs show all kinds of unification and continuity: 'we are your kinsmen, we want to be your subjects, Israel and Judah belong under one king, your leadership of today and tomorrow was already unmistakable yesterday, and besides, it was ordained by God.' The tenor of unity comes into relief even more due to a moment of dissent. In the flashback political and military powers were separate, Saul was king and you were general. But the separation is now a thing of the past and is lifted in the parallelism of $2 \mathrm{de}$. I interpret this pair of lines as having a poetical structure; $4+4$ ictuses and a maximum of word pairs which make the parallelism between the verse halves complete." (Fokkelman, Throne and City, 139)

${ }^{61}$ Auld, I \& II Samuel, 392. 
brotherhood. ${ }^{62}$ By using language that alludes to these passages, the tribes in 2 Sam 5 thus appear to recognize David as a brother Israelite and therefore a suitable candidate for the throne, for the law stipulated that no foreigner "who is not your brother" but only "one from among your brothers" was to be made king (Deut 17:15). ${ }^{63}$ The fact that this declaration of brotherhood is made by all the tribes furthermore suggests that they finally acknowledge the brotherhood of Israel and Judah, putting an end to the war between brothers that dominated the previous three chapters. ${ }^{64}$

Yet as a number of commentators have noted, the reference to bone and flesh seems to encompass a further dimension in that it "also points to a marital or covenantal relation. ${ }^{95}$ By using language associated with the first marital covenant in Gen 2:23, the people recognize David “as a suitable husband for Israel." ${ }^{66}$ This suggests that David's kingship is to be based on a relationship of mutual love, trust and loyalty between king and people. In addition, the terminological connection to Gen 2:23 provides yet another

${ }^{62}$ Leithart, A Son to Me, 203. See also Polzin, David and the Deuteronomist, 54.

${ }^{63}$ Youngblood, "1 \& 2 Samuel," 849; Vannoy, 1-2 Samuel, 292. The link to Judg 9 is also interesting because it highlights the contrast between Abimelech and David. While the former employs the expression "bone and flesh" in order to convince others to make him king, the latter has no need to do so. Rather than actively seeking the throne by reminding the people that he would be a good candidate, he waits for the people to acknowledge their kinship to him and make him king. Thus David's refusal to actively pursue kingship on his own is once again emphasized.

${ }^{64}$ Leithart, A Son to Me, 203.

${ }^{65}$ Leithart, A Son to Me, 204. See also Youngblood, "1 \& 2 Samuel," 849 and Walter Brueggemann, "Of the Same Flesh and Bone (Gn 2,23a)," Catholic Biblical Quarterly 32 (1970): 532-42.

${ }^{66}$ Leithart, A Son to Me, 204. 
link between David and Adam, strengthening the impression that his kingship may be associated with that of the first humans in the garden paradise. ${ }^{67}$

\section{Verse 2}

The link to Gen 2:23 is also interesting in light of the immediately following verse in 2 Sam 5 where the focus switches from the people to David. ${ }^{68}$ The people now turn to the past, noting that even when Saul was king, it was David who led Israel out (יזָ brought them in (בוא). The language they use strongly reminds of 1 Sam 18, where Saul appointed David as commander of a thousand and he went out (ָיָד before the people, causing all Israel and Judah to love him (1 Sam 18:13-16). ${ }^{69}$ This link back to 1 Sam 18 is noteworthy, not only because it underscores that David is a more capable (military) leader than Saul and therefore qualified to become king but also because it is a reminder - just before the "marriage" of king and people - that David earned the love of the people through his leadership. This further confirms that he is indeed a suitable husband for Israel.

Even more important than David's leadership qualities, however, is the fact that he has been divinely appointed to shepherd YHWH's people, which all Israel has now finally come to recognize ( 2 Sam $5: 2 b$ ). The precise wording of the divine promise the people quote is significant. For one thing, Israel is referred to as the people of YHWH,

\footnotetext{
${ }^{67}$ Note that once again, in contrast to Ish-boshet, David is associated with Adam in his unfallen state.

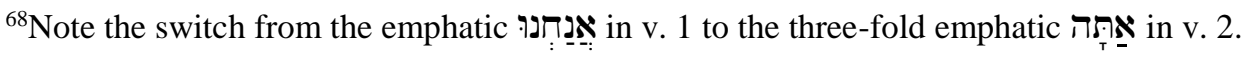

${ }^{69}$ Fokkelman, Throne and City, 140.
} 
making it clear that David is to rule over a nation that belongs to another. This means that even as king David is not the highest authority but functions as the representative of YHWH to whom he is accountable concerning the people who have been entrusted to him. ${ }^{70}$ From the very beginning, David's kingship thus not only includes privileges but also a responsibility towards both the people and YHWH.

This is further emphasized by the shepherd metaphor which suggests that he was "appointed to defend, lead, and tend to the needs of those for whom he was responsible." ${ }^{, 71}$ Just prior to his anointing by the elders of Israel, the metaphor also serves as a reminder that David was divinely chosen and anointed by Samuel long ago when he was still a simple shepherd boy. ${ }^{72}$ Thus the divine sovereignty is emphasized, putting the present anointing into proper perspective: it only confirms David's divine election and makes it "a public and political reality". ${ }^{73}$ The close connection between David and YHWH is further made evident by the fact that YHWH is also presented as Israel's shepherd throughout the Old Testament, suggesting among other things that David's kingship is to be patterned after that of YHWH. ${ }^{74}$ As YHWH rules over his people, so David is to rule over them.

${ }^{70}$ Stolz, Das erste und zweite Buch Samuel, 206.

${ }^{71}$ Bergen, 1,2 Samuel, 318. See also Youngblood, “1 \& 2 Samuel,” 850; Stolz, Das erste und zweite Buch Samuel, 206; Birch, "First and Second Books of Samuel," 1234; van Wijk-Bos, Reading Samuel, 173.

${ }^{72}$ Birch, "First and Second Books of Samuel," 1234.

${ }^{73}$ Arnold, 1 \& 2 Samuel, 452. Brueggemann, First and Second Samuel, 237-38, notes: "By a return to the metaphor of shepherd and sheep at the end of this long narrative, we are able to see how the initial act in I Samuel 16:1-13 with this shepherd boy has had its focus from the outset on the outcome of II Samuel 5:2. It is Yahweh's overriding intention in the narrative that the shepherd boy should become the shepherd of Israel." 
This is not the only connection, however, for as Leithart notes, the shepherd motif also provides yet another link to the patriarchs and in particular to Jacob, who is more closely associated with this profession than Abraham and Isaac. ${ }^{75}$ In addition, there are significant terminological links to Num 27:17 where Joshua is appointed to lead Israel

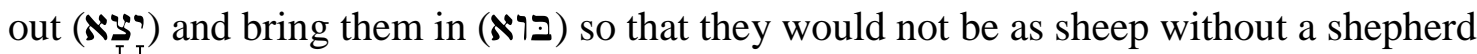
(רעִה). The parallels suggest that David is "a new Joshua, prepared to complete the conquest that Joshua began. ${ }^{.76}$ In light of this, it is not surprising that in the remainder of 2 Sam 5 David is presented as doing just that, defeating both the Jebusites and the Philistines.

The tribes conclude their speech by quoting a second divine promise: David is not only to be shepherd but also נָָגִיד over Israel. The title, whose precise meaning has been the subject of much discussion, is first applied to Saul in 1 Sam 9:16 und 10:1. ${ }^{77}$ In both cases the term is closely connected to divine election and appointment as savior of YHWH's people (9:16) and steward of his inheritance $(10: 1) \cdot{ }^{78}$ Hence it appears that the title designates one who has been chosen by YHWH to serve as his vicegerent, thus distinguishing the earthly ruler of Israel from the heavenly king of the nation, i.e.

\footnotetext{
${ }^{74}$ Stolz, Das erste und zweite Buch Samuel, 206: "Durch die Aussage vom Hirte-Sein Davids ist der König ganz in die Nähe Gottes gerückt, er ist dessen vollmächtiger Statthalter für Israel."

${ }^{75}$ Leithart, $A$ Son to $M e, 204$.

${ }^{76}$ Leithart, A Son to $\mathrm{Me}, 204$.

${ }^{77} \mathrm{~A}$ helpful summary and critique of the different etymological theories is found in Gerhard Hasel,

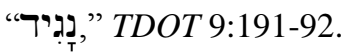

${ }^{78}$ Hasel, TDOT 9:197-99; Vannoy, 1-2 Samuel, 292.
} 
YHWH. That the title is applied to David by YHWH himself therefore not only underscores that he is Saul's rightful successor but also serves as yet another reminder that his kingship over Israel is a divine gift that comes with a responsibility to faithfully serve YHWH, the true king, by completing the conquest and caring for YHWH's inheritance, so that his people may dwell there in peace. ${ }^{79}$ As the example of Saul shows, it is only by being faithful in his role as shepherd of YHWH's people that David can remain נגירגיד over Israel.

\section{Verse 3}

It does not seem accidental that the introductory הַּם 2 Sam

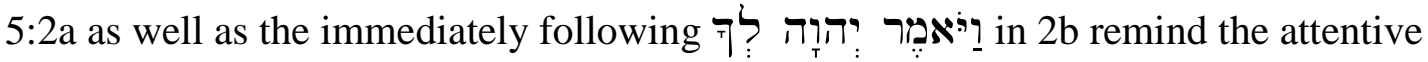
reader of Abner's speech to the elders of Israel in 3:17 by which he sought to persuade them to make David king over Israel. ${ }^{80}$ While they remained surprisingly passive back then, now they take action and come to David at Hebron. The contrast once again underscores that David does not become king thanks to Abner's persuasive powers. Only when the people themselves recognize that David has been divinely chosen, do the elders become active. From the very beginning, David's kingship is thus disassociated from any kind of coercion or manipulation. He becomes king because the people freely acknowledge that YHWH has chosen him.

\footnotetext{
${ }^{79}$ Vom Orde, Das zweite Buch Samuel, 72-73; Stolz, Das erste und zweite Buch Samuel, 206.

${ }^{80}$ Fokkelman, Throne and City, 140.
} 
Just as all the tribes of Israel came in v. 1, so now all the elders come to Hebron, once more highlighting the unity of the nation at this point of the narrative. The author also explicitly notes that they come to "the king". That David is designated in this way for the first time in this section just after the tribes' declaration of the divine promise concerning David further emphasizes the fact that his kingship is based on his election by YHWH, reaffirming that the anointing by the elders later in the verse is a ratification of David's anointing by YHWH through Samuel back in 1 Sam $16 .{ }^{81}$ At the same time the reference to David as king which is repeated two more times in v. 3 also highlights David's sovereignty. He does not seek out the elders; rather they come to him, suggesting that "their need for him is greater than his for them." 82

The king's sovereignty is further made evident in the very next statement, for contrary to what Abner envisioned back in 2 Sam 3:21 it is not the people who make a covenant with the king but the other way around: "king David made a covenant with them". ${ }^{83}$ The act is significant, in particular since the term iִִִּ with the coronation of any other king in the Old Testament, highlighting "the special nature of David's monarchy." 84 As Birch notes,

the basis of Davidic rule over Israel will not be raw power, but willingness on his part to enter covenant. His kingship is established on the basis of a covenant involving mutual recognition of needs and responsibilities. ${ }^{85}$

\footnotetext{
${ }^{81}$ Birch, "First and Second Books of Samuel," 1234; vom Orde, Das zweite Buch Samuel, 73.

${ }^{82}$ Youngblood, “1 \& 2 Samuel,” 851.

${ }^{83}$ Youngblood, "1 \& 2 Samuel,” 851; Fokkelman, Throne and City, 141.

${ }^{84}$ Fokkelman, Throne and City, 142.

${ }^{85}$ Birch, "First and Second Books of Samuel," 1234. See also Firth, 1 \& 2 Samuel, 363.
} 
The allusion to Abner's statement in chapter 3 also underscores the fact that the covenant in 5:3 is not the result of Abner's efforts, once again showing that David is not dependent on any human help to become king. Instead, he reaffirms his and the people's dependence on and accountability towards the divine king by making the covenant "before YHWH" an element that is also strikingly absent from Abner's speech in 3:21. Whatever rights and obligations on the part of both king and people the covenant entails, they are agreed upon in the presence of YHWH, making him "the witness and patron of the contract between this king and his subjects." ${ }^{" 86}$ In this way, YHWH's role as the ultimate ruler over Israel is once more emphasized at the very beginning of David's kingship.

It is precisely the fact that the covenant is made before $\mathrm{YHWH}$ which reminds the attentive reader of the covenant between David and Jonathan in 1 Sam 23:18 - the only

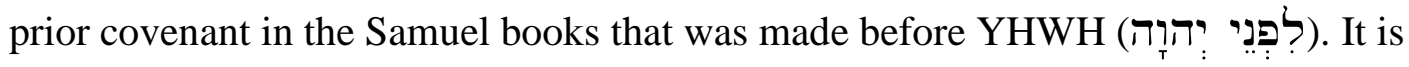
probably not coincidental that the allusion occurs just at the point where Jonathan's bold declaration that David will be king over Israel (1 Sam 23:17) is about to become reality. At the same time, the attitude of love, respect, humility and faithfulness that David and his "brother" Jonathan (2 Sam 1:26) show towards one another and Jonathan's willing acknowledgment of David's election, both of which provide the basis for their covenant, serve as an example to the two parties who are now entering into a covenant before YHWH. Only if they demonstrate this same attitude and if the people continue to humbly recognize David as YHWH's anointed, will their covenantal relationship be truly successful and real unity between brothers possible.

\footnotetext{
${ }^{86}$ Fokkelman, Throne and City, 141.
} 
As David was anointed by the men of Judah at Hebron as king over the house of Judah in 2 Sam 2:4, so he is now anointed at the same place by the elders of Israel as king over Israel. As already noted, the ceremony recalls and affirms the first anointing by Samuel back in 1 Sam 16. Careful study of this earlier passage as well as of the previous

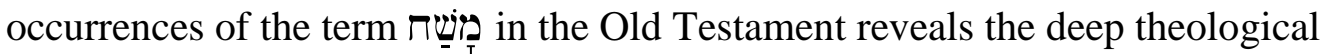
significance of this sacred act. The anointing indicates that David is set apart by divine election as YHWH's representative and for his service. ${ }^{87}$ He thus has both a special status as well as special obligations: he "must always... act with reference to God and his purposes." ${ }^{88}$ In order to accomplish this, he receives the gift of the Spirit of YHWH (1 Sam 16:13). ${ }^{89}$ That David is anointed for the third time in 2 Sam 5:4 therefore strongly underscores the spiritual nature of his kingship. He is not just a political leader but primarily the Spirit-filled representative of YHWH, tasked with the spiritual leadership of YHWH's people.

\section{Verses 4-5}

The unit closes with a statistical note comprising three elements. First David's age when he became king is given, then the total length of his reign and finally the number of years he reigned in Hebron and Jerusalem, respectively. The note functions as the counterpart to 2 Sam 2:10 where the same data is given for Ish-boshet. A comparison of

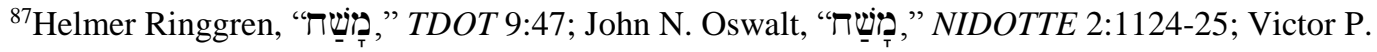

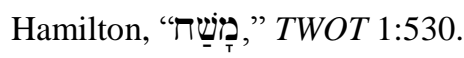

${ }^{88}$ Oswalt, NIDOTTE 2:1124.

${ }^{89}$ Ringgren, TDOT 9:47; Hamilton, TWOT 1:530.
} 
the numbers once again shows David's superiority: he is ten years younger than the son of Saul when he ascends to the throne of Israel and rules the nation twenty times longer, namely forty years - a period associated with one full generation and therefore indicating "a full term of governing." ${ }^{90}$ In addition, the numbers thirty and forty add up to ten times the number seven, matching the ideal given in Ps 90:10. ${ }^{91}$

David's age when he becomes king may also have deeper significance. In light of the connections between his kingship and the sanctuary/priesthood noted in particular in the analysis of 2 Sam 2:1-11 above, it is interesting that David first becomes king at the very age when men from the tribe of Levi could begin to serve at the tabernacle (see e.g. Num 4:47). ${ }^{92}$ In combination with the anointing in the previous verse, the explicit mention of David's age thus appears to be another subtle indicator that in his role as king David also functions as a priest who mediates between YHWH and his people.

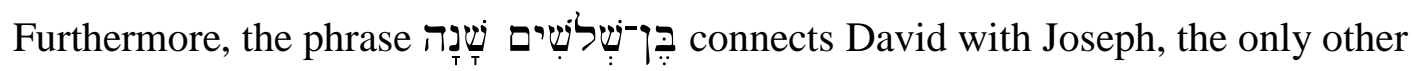
person designated in this way in the Old Testament (Gen 41:46).${ }^{93}$ The link to Joseph is quite fitting at this point of the narrative, for just as Joseph's brothers came to him after the seven years of plenty, leading to the reunification of the family, so now all the tribes of Israel come to David after his seven years as king at Hebron, bringing to an end the war between brothers and leading to the reunification of the nation. These parallels not

\footnotetext{
${ }^{90}$ Alter, The David Story, 221. See also Fokkelman, Throne and City, 142.

${ }^{91}$ Youngblood, "1 \& 2 Samuel," 851; Fokkelman, Throne and City, 142.

${ }^{92}$ Youngblood, "1 \& 2 Samuel," 851 . Note that 2 Sam 5:4 is the first time the age of thirty is mentioned after Num 4.

${ }^{93}$ Youngblood, "1 \& 2 Samuel," 851. Is it accidental that all the years mentioned in 2 Sam 5:4-5 add up to 110, the age when both Joseph (Gen 50:22) and Joshua (Josh 24:29) died?
} 
only further confirm David's role as savior of Israel but also suggest that the attitude of Joseph and his brothers toward one another serves as an example for David and the tribes of Israel. As already noted above, true reconciliation and unity will only be possible as king and people engage with one another in a spirit of love and genuine brotherhood.

\section{Implications for the Nature of David's Kingship}

As the exegetical analysis above has shown, many aspects of David's kingship already noted in previous literary units are reaffirmed in this final passage. At the same time, a number of key new elements are introduced that provide further insight into the nature of David's kingship.

\section{The Legitimacy of David's Kingship}

Chosen by YHWH. Both the divine promise that David is to shepherd YHWH's people as well as the fact that he is designated as "the king" twice immediately after this promise is quoted by all the tribes and just prior to his anointing by all the elders of Israel serve as subtle reminders that David was divinely chosen to be king as a young shepherd boy, long before he actually took the throne. Like the anointing by the men of Judah in 2 Sam 2:4, this third anointing confirms the first anointing by YHWH through Samuel in 1 Samuel 16.

נִָ Iִיד over Israel. David's divine election is further confirmed by the fact that he is designated by the special title נָּגִיד. In addition, this title identifies David as the rightful successor of Saul, the only previous individual to be designated in this way in the Old Testament. The title thus strongly underscores the legitimacy of David's kingship. 
Recognized by the people. The tribes' speech to David reveals that, as in previous units, the people recognize both David's divine election as well as his suitability to be king over Israel. They do so of their own accord, without any coercion or manipulation on David's part. By using language alluding to the first marital covenant in Gen 2:23 in their opening statement in 2 Sam 5:1, the tribes specifically affirm that they consider David to be a suitable husband for Israel. This is not surprising given that the allusion to 1 Sam 18 in 2 Sam 5:2 reminds the attentive reader that David earned the love of the people through his leadership.

Qualified by his character. By waiting for the people to take the initiative, David once more demonstrates patience and trust in YHWH and reaffirms that he will not seize the throne by force. When the tribes do approach him, he readily enters into a covenant with them before YHWH, showing that he is willing to care for the people and be held accountable for his leadership, while at the same time humbly recognizing that the ultimate ruler of Israel is YHWH.

Qualified by his experience. The allusion to $1 \mathrm{Sam} 18$ in the speech of the tribes in 2 Sam 5:2 serves as a reminder that David already proved himself to be a more capable and trustworthy (military) leader than Saul in the past, for even when the latter was still king, it was David who led Israel out into battle and brought them back home safely. The very practical experience he gained in this way serves as further evidence that he is absolutely qualified to be king over Israel. 


\section{Foundational Elements of David's kingship}

Unity. As the above analysis has shown, both the form (e.g. the structure, the many word pairs in the speech of the tribes, etc.) and the content of the unit once again underscore that David's kingship is strongly associated with the unity of Israel. Not only has the war between brothers finally come to an end as the unit opens, but all the tribes as well as all the elders of Israel come to Hebron together to make David king. Already in the opening statement of their speech, the united tribes indicate their desire for unity with David by presenting themselves as belonging to his body, to which David responds favorably by making a covenant with all the elders of Israel, thus sealing the union between him and the people. The unity and completeness of David's body that is emphasized in this way once more distinguishes his kingship from that of Saul and his house, since the latter is characterized by discord and division fittingly symbolized by the mutilated bodies of Saul, Ish-boshet and Ish-boshet's two captains. That David's kingship is associated with the concept of unity is further underscored by the allusions to the first marriage in Gen 2:23, to David's covenant with Jonathan in 1 Sam 23 as well as to the story of Joseph and his brothers in Gen 41ff.

Love and loyalty. The allusions to the three passages just mentioned are also significant because they serve as reminders that true unity will only be possible if David's kingship is based on a relationship of mutual love and loyalty between king and people. Only if both parties are truly committed to each other will their union be successful.

Covenant. That both king and people are willing to commit to one another is made evident by the covenant which David makes with the elders of Israel. As pointed out 
above, this covenant highlights the unique and foundational nature of David's kingship, since no other king in the OT enters into such an agreement with his subjects. David's willingness to make a covenant reaffirms that his kingship will not be based on fear or the abuse of power but on the "mutual recognition of needs and responsibilities." 94 That the covenant is made in the presence of YHWH not only emphasizes the solemn nature of the agreement but also suggests that the union between king and people will only be successful as long as YHWH is recognized as covenant partner and ultimate ruler of Israel, meaning that he is the true provider of the nation as well as the one to whom both king and people are ultimately responsible.

Sovereignty. Contrary to the weak Ish-boshet who is acted on by others and ends up being killed by his own subjects in the previous chapter, David is once more portrayed as a sovereign monarch in the present literary unit. Even before his anointing he is twice referred to as king and instead of him seeking out people and elders, they come to him. Also, he makes a covenant with the elders, rather than the people making a covenant with him.

YHWH's representative. If YHWH is the ultimate ruler of Israel, it follows that David functions as his representative. This is emphasized by his anointing which recalls and affirms the first anointing in 1 Sam 16 as well as by the fact that he is divinely appointed as shepherd of YHWH's people. As such he is to pattern his kingship after that of YHWH and rule over Israel as YHWH does. This also means that he is not just a

\footnotetext{
${ }^{94}$ Birch, "First and Second Books of Samuel," 1234.
} 
political leader, but that his primary task is to provide spiritual leadership to Israel, continually pointing them to YHWH, the ultimate shepherd-king.

Dependence on and Accountability to YHWH. Even as sovereign monarch David is thus not the highest authority in the nation. Rather he is both dependent on and accountable to YHWH. By making the covenant with the elders before YHWH, David demonstrates his awareness of this reality and his willingness to submit to YHWH's leadership. This again sets his kingship apart from that of Ish-boshet and Abner.

\section{The Purpose of David's kingship}

Return to the Edenic model. In particular through the allusion to Gen 2:23 in the speech of the tribes in 5:1 David seems to be once more associated with Adam, providing further support for the view that his kingship is to be modeled after that of Adam and Eve in Eden. Having returned to the land and moved to Hebron (both locations that are associated with the garden mentioned in Gen $2-3$ as noted above), David now receives his "wife" Israel as a gift in order to love and care for her. As in 2 Sam 2:1-11, and in contrast to 2 Sam 3:1-5, David is thus associated with Adam in his unfallen state, once again highlighting the contrast between him and Ish-boshet.

Finish the conquest. David seems to be associated not only with Adam but also with Joshua as the terminological and thematic parallels between Num 27:17 and 2 Sam 5:2 suggest. Like Moses' successor, he is to shepherd Israel, leading them out into battle and bringing them back home safely so that the conquest may be completed and the people may possess the land as YHWH promised. Significantly, this is precisely what David does in the remainder of 2 Sam 5. 
Care for YHWH's people and inheritance. As divinely appointed husband, shepherd, and נָּגִיר over Israel David is tasked with protecting, guiding and caring for YHWH's people and inheritance in the same way YHWH does. His kingship is thus strongly associated with sacrificial service for all that has been entrusted to him by YHWH.

Salvation for Israel. Together with his anointing, the fact that David's age at the time he becomes king over Judah corresponds to the age when Levites could begin serving at the tabernacle provides further support for the view that David's kingship also includes a priestly aspect. That David is to be actively involved in Israel's salvation is further confirmed by the title נִִָָג as well as by the parallels to the Joseph story. 


\section{CHAPTER 5}

\section{CONCLUSION}

The exegetical analysis of 2 Sam 2:1-5:5 conducted in this study has demonstrated that this literary unit is a carefully crafted work of art throughout which the kingships of David and Ish-boshet/Abner are compared and contrasted. Based on the above close reading of the passage, the following conclusions have emerged regarding the nature of David's kingship.

\section{The Legitimacy of David's Kingship}

The legitimacy of David's kingship is affirmed throughout 2 Sam 2:1-5:5 in the following ways:

Chosen by $Y H W H$. David is the legitimate king of Israel first and foremost because he has been chosen by YHWH. His divine election is explicitly acknowledged by both Abner in 2 Sam 3:18 and all the tribes of Israel in 2 Sam 5:2. In addition, David's initial anointing at YHWH's command in 1 Sam 16 is alluded to at crucial junctures in the narrative, namely in 2 Sam $2: 4,8$ and 2 Sam 5:2. The allusion in 2 Sam 2:8 is also significant with regard to Ish-boshet for the hiphil form of עָ in 2 Sam 2:8 links him to David's brothers who were not chosen. David, on the other hand, is associated with the divinely chosen Judah and Gideon through verbal links to Gen 38 and Judg 8 in 2 Sam 3:2-5. Furthermore, the allusions to the story of Isaac and Ishmael in 2 Sam 2:13-15 cast 
David in the role of the divinely chosen son Isaac, while Saul's biological son Ish-boshet seems to be associated with Ishmael. Thus, David's divine election is affirmed in a variety of ways throughout the narrative.

Recognized by Saul and the people. Significantly, David's divine election is recognized not only by the men of Judah who affirm his anointing at YHWH's command (2 Sam 2:4), as well as by all the tribes of Israel in their speech prior to his anointing by the elders of Israel (2 Sam 5:2), but also by Saul himself, as the attentive reader of 2 Sam 2:1-11 is reminded of through a number of allusions to 1 Sam 24. In each case, the recognition is not the result of manipulation or coercion on David's part but is freely given. In addition, it is noteworthy that while Saul explicitly acknowledged David as his rightful successor, there is no textual evidence that he ever made such a statement concerning Ish-boshet.

Associated with the faithful Saul. The legitimacy of David's kingship is also underscored by his interaction with the men of Jabesh-Gilead that associates him with the faithful Saul of 1 Sam 11 who interacted with the same group just after his anointing. Ishboshet, on the other hand, is linked to the disobedient and rejected Saul through the allusion to 1 Sam 13 in 2 Sam 2:10.

Qualified by his character. David's character is made evident in particular through his attitude concerning the acquisition of power and through the way he relates to others. Rather than selfishly seizing the throne by force and exacting revenge on those who were loyal to Saul, he patiently waits on YHWH and treats even those who could be considered enemies with respect. Instead of rejoicing over the deaths of Abner and Ishboshet and using them to his own advantage, he mourns the slain and condemns the 
murderers. Throughout 2 Sam 2:1-5:5 he is interested in the unity of Israel and consistently seeks to resolve conflict by peaceful rather than violent means. This sets him in stark contrast to Abner and Ish-boshet as well as to the sons of Zeruiah, all of whom are driven by selfish and vengeful motives, fail to wait on YHWH and through their actions initiate and prolong a civil war that divides the nation and leads to bitterness and death. Thus, they repeat the mistakes of the rejected Saul who disqualified himself from being king over Israel.

Yet David is also not exempt from failure. As his marriages to multiple wives in 2 Sam 3:1-5 as well as his attempts to gain the kingship over all Israel in the first part of 2 Sam 3:6-39 demonstrate, he is far from perfect and in danger of becoming like those he was contrasted with before. Significantly, it is precisely at this point in the narrative that David seems to act on his own without the guidance of YHWH. This suggests that David's caring and unselfish attitude that sets him apart from Saul and those like him is not simply a natural part of who he is but is directly dependent on his connection to YHWH.

Qualified by his personality. In contrast to the passive, weak and fearful Ishboshet who is acted upon by others, David is generally presented as a proactive, decisive and capable leader. He inquires of YHWH, goes up to Hebron with his men, sends messengers to the men of Jabesh-Gilead and fathers six sons. Unlike Ish-boshet, who is completely at the mercy of his general Abner and ends up being killed by his own men, David stands up to both Abner and Joab and has Ish-boshet's murderers executed.

Qualified by his experience. David is also qualified to be king over Israel because of his experience as (military) leader of Israel that is explicitly noted by the tribes in 2 
Sam 5:2. The allusion to $1 \mathrm{Sam} 18$ is a reminder that David successfully led Israel into battle and ensured that they returned home safely, proving that he is a capable and trustworthy leader for Israel.

Qualified by his title. The legitimacy of David's kingship is further confirmed through the special title נָָגָ mentioned in the speech of the tribes in 2 Sam 5:2 that identifies him as YHWH's viceregent and Saul's rightful successor.

\section{Foundational Elements of David's Kingship}

Divine Guidance. Of all the elements of David's kingship noted in this study, divine guidance may well be the most foundational. The central importance of this aspect for the success of David's kingship is emphasized not only by the placement of his inquiry of YHWH at the very beginning of the account of his kingship but also through the allusions in 2 Sam 2:1-4 to 1 Sam 27:1-7 that highlight the contrast between the negative experience of David and his men in that passage and the positive experience at the beginning of 2 Sam 2. David's interest in divine guidance sets him apart from Abner, Ish-boshet and the sons of Zeruiah who never inquire of YHWH, but instead selfishly take matters into their own hands. In contrast to David's kingship, the kingship of Ishboshet is thus based on selfish human ambition. The negative consequences that result from this further underscore how crucial it is that Israel's king be guided by YHWH. This also becomes evident in 2 Sam 3 where David himself departs from his former course and fails to seek divine guidance, though a number of allusions to the stories of the patriarchs and Israel suggest he should have done so. Instead, he seeks to gain kingship over all Israel by less than ideal means. As a result, his position as a leader is weakened 
rather than strengthened and he is in danger of losing control just like Ish-boshet. Yet unlike the son of Saul, David in his hour of greatest weakness once again humbly recognizes his need for YHWH, asking him to repay those who do evil according to their wickedness.

Obedience to YHWH's will and law. A second, closely related element associated with David's kingship is obedience to YHWH's will and law. Here also the contrast to Ish-boshet's kingship is striking. While the latter begins with an act of blatant rebellion against YHWH's will, the account of David's kingship opens with a report of David's obedience to the divine will as he goes up to Hebron according to YHWH's directions. David's regard for the divine law and his commitment to keep it is also made evident in 2 Sam 4 when he condemns Ish-boshet's murderers with language reminding of Gen 9:5 and Deut 19:13, 19 and has them executed as the law commanded. The sons of Rimmon, on the other hand, kill in violation of the divine law, repeating the mistake of the participants in the battle of Gibeon in 2 Sam 2 whose disregard for YHWH's will and law is revealed not only in the fact that they kill their neighbor (רֵֵַ), instead of loving him as the law demanded (Lev 19:18), but also through the wording in 2 Sam 2:19, 21 that alludes to the divine instructions to keep the law found throughout the book of Deuteronomy as well as in Joshua 22. Though David is conspicuously absent from this episode, distancing him from those who show little interest in the divine law, he also struggles in this area as shown by his multiple marriages reported in 2 Sam 3 that are not in harmony with the divine command given in Deut 17:17. The negative consequences of those marriages for his kingship that become evident later in 2 Samuel only serve to underscore the importance of obedience to YHWH's will and law for David's kingship. 
Justice. As long as David is guided by YHWH and obedient to his will, he is able to discern between good and evil and administer true and appropriate justice that is not swayed by personal feelings or benefits but is based on the divine law. This becomes evident not only in his dealings with the men of Jabesh-Gilead in 2 Sam 2 but also in his treatment of the sons of Rimmon in 2 Sam 4 that stands in stark contrast to the selfserving and inappropriate (in)justice administered by Abner, Joab, Asahel and the sons of Rimmon. Yet when David acts in violation of the law and fails to inquire of YHWH as in 2 Sam 3, he is in danger of becoming an incompetent judge like Ish-boshet who is unable to bring his general to justice. Significantly, however, David again distinguishes himself from the son of Saul in this situation by consigning the evildoers to YHWH's judgment, thus recognizing him as the highest judge who alone can ultimately administer true justice.

Unity. From the very beginning of his kingship, David is interested in uniting rather than dividing Israel as his message to the men of Jabesh-Gilead demonstrates. Abner, on the other hand, provokes strife and disunity in Israel by installing Ish-boshet as king and suggesting a contest between fellow Israelites that leads to civil war. When Abner and David attempt to unite the nation through diplomatic means, their efforts are thwarted by Abner's death at the hands of Joab. While human scheming and demonstrations of power thus do not bring about the desired result, it is - quite unexpectedly - at this very moment of national crisis that could well have caused even greater division that the first signs of unity begin to appear as all the people observe and approve of David's genuine demonstration of grief and respect at Abner's funeral. In the end, the nation is united without any efforts on David's part when all the tribes of Israel 
and all the elders come to Hebron and anoint David as king over all Israel, once more emphasizing that true unity cannot be imposed. This kind of unity is further highlighted through the image of David and the people as one body, through the covenant between king and elders as well as through the allusions to the first marriage in Gen 2:23, to David's covenant with Jonathan in 1 Sam 23 and to the story of Joseph and his brothers in Gen $41 \mathrm{ff}$ in 2 Sam 5:1-5. By contrast, the mutilated bodies of Ishboshet and his two captains in 2 Sam 4 are a final reminder of the division that characterizes the kingship of the son of Saul.

Freedom of choice. Whereas Abner imposes Ish-boshet on Israel, David's interaction with the men of Jabesh-Gilead shows his respect for the people's freedom to choose. He will not force himself on them, instead granting them the freedom to decide whether they will accept him as their king or not. In light of this, it is also noteworthy that when the men of Judah in 2 Sam 2 and all the tribes in 2 Sam 5 come to Hebron to show their allegiance to David and anoint him as king, they do so of their own free will and not because of any initiative on David's part. By contrast, the people remain strangely passive when David in 2 Sam 3 begins to pursue a course similar to Abner's, symbolically demanding the kingdom and by implication the loyalty of the people by mandating that Michal be given back to him. Significantly, it is not David's demonstration of power but his reaction to Abner's death and in particular his humility and expression of sorrow at the general's funeral that gain him the sympathy of the people. Abner and Ish-boshet, on the other hand, continually lose the support of the people as the narrative progresses. Thus, it becomes evident that true loyalty cannot be forced but must be earned. 
Respect and kindness towards others. One of the ways in which loyalty may be earned is by showing respect and kindness towards others. David does so right at the beginning of his kingship by reaching out to the men of Jabesh-Gilead and commending them for burying Saul. His message stands in stark contrast to the aggression and strife between fellow Israelites that characterizes the remainder of 2 Sam 2 and is instigated by Abner right after he makes Ish-boshet king. Yet in 2 Sam 3 David also shows little concern for others as he orders Michal to be taken from her weeping husband and seemingly disregards his servants returning to Hebron from a raid while providing an elaborate meal for Abner and his men. Once again, it is the death of Abner that marks a turning point as David demonstrates respect and kindness toward the dead general by honoring him with a state funeral. Significantly, this attitude wins him the favor of the people, highlighting its importance for the success of David's kingship. In 2 Sam 4 , David shows the same respect for the dead Ish-boshet by ensuring that his head receives a proper burial. This act is highlighted even further by the parallel panel structure of the passage which contrasts David's respectful treatment of Ish-boshet's head with the way the head is misused by the sons of Rimmon for their own wicked purposes.

Concern for the people. Besides showing respect and kindness towards others, David also demonstrates concern for the people under his leadership. This is revealed in particular through his public declaration following Abner's death in 2 Sam 3:28-29 and through his verdict concerning the sons of Rimmon in 2 Sam 4:11. As the allusion to Deut 19 in the latter verse shows, both statements as well as the execution of Ish-boshet's murderers are necessary acts to protect the people from the consequences of bloodguilt. 
While David is thus interested in the present and future welfare of the nation, Abner and Ish-boshet never demonstrate such concern for the people.

Humility and proper self-assessment. Even before he becomes king, David demonstrates humility by inquiring of YHWH concerning his return to the land and by not making himself king upon his arrival at Hebron. He displays the same attitude once he has been crowned king by not making himself the center of attention but rather focusing on others and on YHWH as his first recorded act as king in 2 Sam 2:5-7 reveals. David's interaction with the men of Jabesh-Gilead further demonstrates that he knows his place in relation to YHWH, once more setting him in contrast to Abner, who proudly puts himself in YHWH's place by installing Ish-boshet as king. As he begins to disregard the divine will in 2 Sam 3, however, David is in danger of following the general's example and become proud and demanding. Significantly, this does not gain him the kingship over all Israel. When the death of Abner reveals the folly of relying on human strength, David once more demonstrates great humility and self-awareness through his behavior at Abner's funeral and his open admission of his own weakness at the very end of 2 Sam 3. In contrast to the sons of Rimmon who take matters into their own hands in order to make David king over all Israel, David takes no action to secure kingship for himself in 2 Sam 4 and 5 but just like in 2 Sam 2 humbly waits for YHWH and the people to act.

$70 \pi$ and repaying good with good. This element of David's kingship is highlighted from the very beginning of his kingship. In his first recorded royal act David commends the men of Jabesh-Gilead who showed חִ to Saul, wishes for YHWH to show חֶֶ to them in return and promises to do likewise, emphasizing that his kingship is 
based on relationships of mutual חֶֶֶ between YHWH, king and people. In 2 Sam 3, David acts like the men of Jabesh-Gilead by mourning over Abner and ensuring that he receives a proper burial. Abner, on the other hand, only claims to show is driven by selfish ambition from the very beginning. Already in 2 Sam 2 this attitude leads to a situation where evil is repaid with evil, resulting in bitterness, pain and death and ultimately ending Ish-boshet's kingship. In this way the importance of success of David's kingship is affirmed.

Sorrow over evil. After mourning over Saul and his sons just prior to becoming king over Judah and commending the men of Jabesh-Gilead for burying Saul as his first recorded royal act, David seems to become indifferent to the pain of others in 2 Sam 3 as he demands that Michal be taken from her weeping husband. He is thus fast on his way to become like Abner, the sons of Zeruiah and the sons of Rimmon who initiate and prolong evil rather than sorrow over it. When Abner is brutally murdered, however, David once more responds with profound sorrow, despite the fact that he could well have rejoiced over the general's death or remained indifferent. Through his public demonstration of grief, he underscores that evil is a cause for mourning rather than rejoicing.

Peace. Unlike Abner, the sons of Zeruiah and the sons of Rimmon who instigate strife and disharmony and are associated with violence and death throughout the narrative, David consistently refrains from violence and publicly condemns its use in both 2 Sam 3 and 4. In harmony with his course of action in the past, he does not attempt to gain kingship through violent means but instead seeks to prevent further aggression. His desire to unite Israel through peaceful means is revealed not only through his 
message to the men of Jabesh-Gilead but also through his treatment of Abner whom he welcomes with a meal and sends away in peace rather than seeking revenge like Joab. David's kingship is further associated with peace through the name of his third son Absalom as well as through the striking contrast between the battle narrative in 2 Sam 2:12-32 and the description of David's family in 2 Sam 3:2-5. Yet the apparent calm is deceptive for the mention of multiple wives as well as a number of allusions to the families of Jacob, Judah and Gideon in the latter passage already suggest that it is a fragile peace. This is not surprising given that David's multiple marriages are a clear violation of the divine law. Hence, the passage further underscores what is revealed throughout the surrounding narratives, namely that disobedience to YHWH's law in the end only leads to conflict and unrest. As David himself recognizes at the end of 2 Sam 3, the only one who can really solve this problem and thus establish true and lasting peace is YHWH himself.

Strength and Continuity. The opening verses of 2 Sam 3 also emphasize the strength of David and his kingship. Besides being highlighted by both the form and content of verse 1 , this aspect is also accentuated by the birth list in verses $2-5$, for in contrast to the weak Ish-boshet who is not even mentioned in this passage and appears to have no offspring, David is presented as a virile individual who fathers six potential successors to the throne. His kingship thus seems secure, while that of Ish-boshet is associated with the dead and rejected Saul. The same contrast is also evident in the following passage in 2 Sam 3 where David is clearly in charge of the proceedings, with Abner and Ish-boshet merely executing his will. The weakness of the son of Saul is 
further emphasized in the opening scene of this narrative where he is unable to assert himself against his own general and cannot prevent him from defecting to David.

As imposing as David's strength may seem, it is not without problems, since it is at least partially achieved by disobedience regarding the divine law (2 Sam 3:2-5) and employed selfishly and without concern for the people (2 Sam 3:12-16). Significantly, it also does not gain David kingship over all Israel as Abner is suddenly killed nor does it ensure the continuity of his kingship for none of the sons in the birth list successfully succeed him as king. Instead, David quickly becomes surprisingly weak, unable to respond to Joab's accusations, prevent him from killing Abner or bringing him to justice for the murder. Yet it is this moment of greatest weakness after the death of Abner, when the idea of a united Israel under David's leadership seems more unrealistic than ever, that turns out to be a moment of strength, for as David recognizes his need for YHWH and once more begins to fully rely on him, he is able to demonstrate great strength of character through his public condemnation of the murder and his genuine expression of grief at Abner's funeral. In addition, the people's favorable reaction in this situation actually places him in a stronger position than before. Hence, the development within the narrative suggests that true strength that will ensure the continuity of David's kingship over all Israel is the result of complete reliance on YHWH.

\section{The Purpose of David's Kingship}

Return to the Edenic model. The parallels between Eden and the Promised Land and the possible association of Hebron with the garden of Gen $2-3$ raise the possibility that David's kingship is linked to that of the first humans. This impression is further 
strengthened by the allusion to Gen 2:23 in 2 Sam 5:1 through which David is associated with Adam and the people with Eve. Just as Adam receives his wife as a gift and enters into the covenant of marriage with her, so David receives the people without any effort of his own and makes a covenant with them. His commendation of the men of JabeshGilead further suggests that the people in David's kingdom are to act like YHWH, associating his kingship with the restoration of God's image in human beings.

While David seems to be linked to Adam in his unfallen state in Gen $1-2$, Ishboshet appears to be associated with the fallen Adam in Gen 3 who disobeys God and seeks to rule on his own terms, resulting in shame and a departure from his former dwelling place. In this way the contrast between the two kingships is highlighted once more. Yet in 2 Sam 3 David himself disobeys as he marries multiple women and seeks to gain kingship in his own strength. As in Adam's case, David's disobedience is eventually followed by serious conflict between his sons, with one organizing the murder of his brother, and almost leads to the loss of David's kingship. This suggests that a return to the Edenic model is only possible as long as David is faithful to YHWH and guided by him.

Finish the conquest. In order for such a return to the Edenic model to be realized, the conquest which Israel failed to complete must be finished. That this is an important purpose of David's kingship is indicated in particular by various allusions throughout 2 Sam 2:1-5:5 to the time of the conquest in the books of Numbers, Deuteronomy, Joshua and Judges. Like Israel at the beginning of the book of Judges, David moves up into the land after inquiring of YHWH and goes to Hebron. In order to finish the conquest, he needs sons of valor whose hands have been strengthened to fight the battles 
of YHWH. Due to the selfishness of Abner, Ish-boshet and the sons of Zeruiah, however, a civil war breaks out in Israel, resulting in violence and unrest. In 2 Sam 3 David himself marries the daughter of a Canaanite king and seeks to gain an inheritance on his own terms, leading to more strife and disharmony on the domestic front. That David instead should have been concerned with finishing the conquest is emphasized through the allusions to 1 Sam 18 and Josh 23. This concern for completing the conquest is also highlighted in 2 Sam 5:2 through the allusion to Num 27:17 that links David with Joshua. This time, David follows through, as the remainder of 2 Sam 5 demonstrates.

Salvation for Israel. If the completion of the conquest, which makes a return to the Edenic model possible, is an important purpose of David's kingship, it follows that his kingship is closely associated with the salvation of Israel. In light of this, it is significant that David reigns at Hebron, which was both a city of refuge and a place of worship linked to the original garden sanctuary as well as to the wilderness tabernacle. In this city that was given to the priests who work at the sanctuary David is anointed at the very age when men from the tribe of Levi could begin serving at the tabernacle, suggesting that his kingship also includes a priestly aspect. Further confirmation that David is linked to Israel's salvation is provided by the fact that he is designated as and associated with Joseph in 2 Sam 5.

The kingship of Abner and Ish-boshet, on the other hand, is not associated with salvation but with sin, since it is based on selfish ambition coupled with disobedience to YHWH and precipitates division and bitter strife between fellow Israelites, as well as darkness and death. Rather than being an agent for the salvation of Israel, this kingship thus leads the nation further and further into sin. In 2 Sam 3 David also transgresses the 
divine law and begins to selfishly grasp for kingship, precipitating more violence between brothers. Yet in contrast to Abner and Ish-boshet he only pursues this course of action temporarily, once more demonstrating great humility and confessing his dependence on YHWH after the death of Abner. Thus, he exhibits the very attitude that is necessary for Israel to experience the salvation of YHWH.

Care for YHWH's people and inheritance. In contrast to Ish-boshet who is made king by Abner out of selfish motives, seemingly without any concern for the people, David is divinely appointed as husband, shepherd, and נָָגִ over Israel. As YHWH's representative, he is to protect, guide and care for YHWH's people and inheritance in the same way YHWH does. While Abner and Ish-boshet serve only themselves, David is thus called to sacrificially serve what has been entrusted to him by YHWH.

\section{The Portrait of David}

Contrary to those claiming that David is presented in a very positive light throughout 2 Sam $2: 1-5: 5$, the close reading conducted in this study has revealed that the portrait of David in this literary unit is more complex.

In 2 Sam 2 David is indeed portrayed positively, especially in comparison to the other characters that appear in this chapter. Already in the first few verses of the chapter various allusions to 1 Sam 16 and 24-26 remind the attentive reader that David rather than Ish-boshet has been divinely chosen as king. While Abner and Ish-boshet thus act in disobedience to the divine plan by selfishly grasping for kingship, David does not actively pursue kingship but instead humbly waits on YHWH and obediently follows his guidance. Whereas he is anointed as king by the people, Ish-boshet is never anointed and 
made king by a single individual. From the very beginning, Ish-boshet is thus presented as a weak and passive character who seems to have no will of his own but is acted upon by another. David, on the other hand, is an active individual who takes initiative at the proper time and deliberately seeks divine guidance, expressing his desire for YHWH to take control. While David's first recorded royal act is to send a peaceful message of blessing to the men of Jabesh-Gilead, Abner's first move is of a military nature and provokes resistance, leading to the outbreak of violence that ends in a long civil war. While David seeks to reconcile and unite, Abner divides. This division is also made possible and prolonged by the sons of Zeruiah whose attitude reflects that of Abner. Like him, they selfishly seek to take matters into their own hands and execute justice on their own terms, not afraid to use violence in the process. Yet instead of taking responsibility for the ensuing unrest, they blame it on others, making themselves appear as victims. Like Abner, they thus serve as foils for David who is presented as seeking the good of those he could have considered his enemies.

While the portrait of David is positive throughout $2 \mathrm{Sam} 2$, it becomes more ambiguous in 2 Sam 3. On the one hand, David is presented as increasing in strength and fruitfulness, peacefully dwelling at Hebron with his growing family. In this way he is set apart not only from the violence between brothers that dominates the immediately preceding narrative but also from the weakening house of Saul. In contrast to the weak and apparently childless Ish-boshet, David's kingship seems secure. At the same time, however, David's fruitfulness and strength are not entirely unproblematic, for by fathering children with six different women, David departs from the divine ideal regarding marriage and transgresses the express command of YHWH given in Deut 17. 
By partnering with Abner and demanding Michal to be given back to him David also for the first time seeks to gain kingship through human strength and wisdom. Significantly, this course of action does not strengthen his position but weakens it instead, causing him to lose control as he is unable to answer the angry accusations of Joab and to prevent him from killing Abner. Thus, he is fast on his way to become like the weak and passive Ishboshet.

Unlike Abner and Ish-boshet, however, David undergoes a change that appears to be closely connected to the death of Abner. This event becomes a turning point, causing David to once more recognize his need for YHWH and turn to him for help as he entrusts the sons of Zeruiah as well as himself and his kingdom to the justice of YHWH. Though he is outwardly at his weakest and apparently unable to bring his general to justice, this renewed reliance on YHWH enables David to demonstrate great strength of character through his public condemnation of Joab's murder and his remarkable expressions of grief at the funeral of his former enemy Abner. This in turn gains him the support of the people, placing him in a stronger position and bringing him closer to gaining the kingship over a united Israel than he ever was through any efforts of his own.

In 2 Sam 4 and at the beginning of 2 Sam 5 the portrait of David is once more very positive. As in 2 Sam 2, he is presented as a capable and discerning leader who recognizes the true motive of the sons of Rimmon and does not hesitate to bring them to justice. Instead of rejoicing over the death of Ish-boshet and using it to his own advantage, he demonstrates yet again that he will not take the throne by force but will rather wait on YHWH as his speech to the murderers suggests. At the same time, his swift and decisive reaction to the grisly deed shows both his commitment to YHWH's 
law as well as his concern for the well-being of the people whom he desires to protect from the consequences of bloodguilt. The people in turn recognize his divine election as Saul's legitimate successor and YHWH's vicegerent and willingly submit themselves to his leadership at the beginning of 2 Sam 5. The allusion to 1 Sam 18 in the tribes' speech further underscores David's suitability to be king over Israel.

The development David undergoes in 2 Sam 2:1-5:5 is significant not only because it highlights his ability to learn from his mistakes but also because it suggests that these chapters contain an accurate and realistic representation of David. Rather than presenting an idealized version of the king of Judah in an effort to clear him of all possible charges, as some have claimed, the author offers a nuanced portrait of David as a complex individual who is capable of doing both good and evil, of acting in commendable as well as less than ideal ways. How a particular act of David is to be evaluated is made evident in particular through comparisons with other individuals as well as through allusions to previous passages. Careful attention to these literary devices reveals that while David is often presented in a positive light, the author is not afraid to subtly criticize him, when necessary, and/or to indicate what course he should have pursued instead. A close reading of 2 Sam 2:1-5:5 therefore does not support the claim that the David narrative in 1 and 2 Samuel functions as an apology of David in the classic sense.

\section{Perspectives}

At least two suggestions for further research may be drawn from the present study. First, it would be worthwhile to carefully analyze the remaining chapters of 
2 Samuel using a similar approach as that adopted in this study to determine whether the nature of David's kingship changes in any way after he becomes king over all Israel. Is the legitimacy of his kingship further substantiated or not? Are new elements and themes introduced during his reign at Jerusalem and if so, how do they relate to those discovered in 2 Sam 2:1-5:5? Does the purpose of David's kingship remain the same or not?

Second, since Jesus is identified as the Son of David by the writers of the New Testament and his life parallels that of David in many ways, it seems profitable to analyze the typological implications of the conclusions about the nature of David's kingship reached in the present study for the nature of Jesus' kingship. Are there any similarities between the two kingships and if so, how does the former foreshadow the latter? Are there significant differences between the kingships and if so, why? What conclusions may be drawn from the answers to these questions concerning the relationship of the two kingships? In the course of such a study it would be particularly helpful to analyze the messianic significance of the term נָגִיד 


\section{BIBLIOGRAPHY}

Adam, Klaus-Peter. Saul und David in der Judäischen Geschichtsschreibung: Studien zu 1 Samuel 16 -2 Samuel 5. Tübingen: Mohr Siebeck, 2007.

Alter, Robert. The Art of Biblical Narrative. New York: Basic Books, 1981.

Alter, Robert. The David Story: A Translation with Commentary of 1 and 2 Samuel. New York: W.W. Norton \& Company, 1999.

Anderson, Arnold A. 2 Samuel. WBC 11. Dallas, TX: Thomas Nelson Inc.,1989.

Arackal, George V.C. "David's Fall and Redemption: A Study of 2 Samuel 10-12 as a unit of Biblical Narrative Literature." ThD diss., Pontificia Universita Gregoriana, 1996.

Arnold, Bill T. 1 \& 2 Samuel. NIVAC 7. Grand Rapids, MI: Zondervan, 2003.

Auld, A. Graeme, and Erik Eynikel, eds. For and Against David: Story and History in the Books of Samuel. Leuven; Walpole, MA: Uitgeverij Peeters, 2010.

Auld, A. Graeme. I \& II Samuel. OTL. Louisville, KY: Westminster John Knox Press, 2011.

Bailey, Randall C. "A Critical Investigation of 2 Samuel 10-12 and its Implications for the so-called Throne Succession Narrative.” PhD diss., Emory University, 1987.

Bar-Efrat, Shimon. Narrative Art in the Bible. Sheffield: Sheffield Academic Press, 1989.

Bergen, Robert D. 1, 2 Samuel. NAC 7. Nashville, TN: B\&H Publishing, 1996.

Berlin, Adele. Poetics and Interpretation of Biblical Narrative. Sheffield: Almond Press, 1983.

Birch, Bruce C. "The First and Second Books of Samuel." Pages 947-1383 in vol. 2 of The New Interpreter's Bible. Edited by Leander E. Keck. Nashville, TN:

Abingdon Press, 1998. 
Bodner, Keith. "Crime Scene Investigation: A Text-Critical Mystery and the Strange Death of Ishbosheth." Journal of Hebrew Scriptures 7 (2007): 2-18.

Bodner, Keith. David Observed: A King in the Eyes of His Court. Sheffield: Sheffield Phoenix Press, 2005.

Borgman, Paul. David, Saul and God: Rediscovering an Ancient Story. Oxford: Oxford University Press, 2008.

Botterweck, G. Johannes, Helmer Ringgren, and Heinz-Josef Fabry, eds. Theological Dictionary of the Old Testament. Translated by John T. Willis and David E. Green. 15 vols. Grand Rapids, MI: Eerdmans, 1974-2006.

Bromiley, Geoffrey W., ed. International Standard Bible Encyclopedia. 4 vols. Grand Rapids, MI: Eerdmans, 1989.

Brueggemann, Walter. "Of the Same Flesh and Bone (Gn 2,23a)." Catholic Biblical Quarterly 32 (1970): 532-542.

Brueggemann, Walter. First and Second Samuel. IBC. Louisville, KY: Westminster John Knox Press, 1990.

Bungay, Roy G. W. "Narrative Structure and Character Development in 2 Samuel 11." M.A. thesis, Memorial University of Newfoundland, 1996.

Campbell, Antony F. 2 Samuel. FOTL 8. Grand Rapids, MI: Eerdmans, 2005.

Carlson, Rolf A. David, the Chosen King: A Tradicio-Historical Approach to the Second Book of Samuel. Stockholm: Almqvist \& Wiksell, 1964.

Cartledge, Tony W. 1 \& 2 Samuel. SHBC 7. Macon, GA: Smyth \& Helwys Publishing, 2001.

Chisholm, Robert B. 1 \& 2 Samuel. TTC Grand Rapids, MI: Baker Books, 2013.

Clement, Herbert H. "2 Samuel 21-24: Structure, Context and Meaning in the Samuel Conclusion." PhD diss., Coventry University, 1995.

Cohen, Arie. "David and the Gibeonites (2 Samuel 21:1-14)." DHL diss., The Jewish Theological Seminary of America, 1998.

Collins, Billie Jean, Bob Buller, and John F. Kutsko, eds. The SBL Handbook of Style, Second Edition: For Biblical Studies and Related Disciplines. Atlanta, GA: Society of Biblical Literature, 2014. 
Davidson, Richard M. "Cosmic Metanarrative for the Coming Millennium." Journal of the Adventist Theological Society 11 (2000): 102-119.

Davidson, Richard M. "Earth's First Sanctuary: Genesis 1-3 and Parallel Creation Accounts." Andrews University Seminary Studies 53 (2015): 65-89.

Davis, Dale R. 1 Samuel: Looking on the Heart. FBC. Tain, Scotland: Christian Focus Publications, 2010.

Dennison, James T. "Joab and Abner: Narrative Symmetries Sandwiching David: 2 Samuel 3:6-12, 17-39.” Kerux 25 (2010): 27-37.

Doukhan, Jacques. Genesis. SDAIBC. Nampa, ID: Pacific Press Publishing Association, 2016.

Driver, Samuel R. Notes on the Hebrew Text and the Topography of the Books of Samuel. Oxford: Clarendon Press, 1913.

Dumbrell, William J. The End of the Beginning: Revelation 21-22 and the Old Testament. Grand Rapids, MI: Baker Books, 1985.

Edelman, Diana. “The 'Ashurites' of Eshbaal's State (2 Sam 2:9).” Palestine Exploration Quarterly 117 (1985): 85-91.

Eschelbach, Michael. Has Joab Foiled David?: A Literary Study of the Importance of Joab's Character in Relation to David. New York: Peter Lang, 2005.

Eslinger, Lyle M. House of God or House of David: The Rhetoric of 2 Samuel 7. Sheffield: JSOT Press, 1994.

Evans, Mary J. 1 \& 2 Samuel. NIBCOT 6. Peabody, MA: Hendrickson Publishers, 2000.

Exum, J. Cheryl. Tragedy and Biblical Narrative: Arrows of the Almighty. Cambrigde: Cambridge University Press, 1992.

Finamor, Carolyn E. "Perception and Being Perceived in 2 Samuel 11: A Narratological Approach.” M.A. thesis, Trinity Western University, 2007.

Firth, David G. 1 \& 2 Samuel. ApOTC 8. Downers Grove, IL: IVP Academic Press, 2009.

Fishbane, Michael. Text and Texture: Close Readings of Selected Biblical Texts. New York: Schocken, 1979. 
Fokkelman, Jan. Narrative Art and Poetry in the Books of Samuel: A Full Interpretation Based on Stylistic and Structural Analysis. 4 vols; Assen, Netherlands: Van Gorcum, 1981-1993.

Fokkelman, Jan. Reading Biblical Narrative: An Introductory Guide. Louisville, KY: Westminster John Knox Press, 2000.

Fox, Michael. "Ṭôb as Covenant Terminology." Bulletin of the American Schools of Oriental Research 209 (1973): 41-42.

Freedman, David N., ed. The Anchor Bible Dictionary. 6 vols. New York: Doubleday, 1992.

Gordon, Robert P. I \& II Samuel: A Commentary. Grand Rapids, MI: Zondervan, 1999.

Gregory, Mark W. "Narrative Time in the Keret Epic and the Succession Narrative." PhD diss., Southern Baptist Theological Seminary, 1988.

Gronbaek, Jakob H. Die Geschichte vom Aufstieg Davids: (1 Sam 15-2 Sam. 5), Tradition und Komposition. Acta Theologica Danica; Copenhagen: Prostant Apud Munksgaard, 1971.

Gunn, David M. "David and the Gift of the Kingdom (2 Sam 2-4, 9-20, 1 Kgs 1-2)." Semeia 3 (1975): 14-45.

Gunn, David M. The Story of King David: Genre and Interpretation. JSOTSup 6. Sheffield: JSOT Press, 1978.

Halpern, Baruch. David's Secret Demons: Messiah, Murderer, Traitor, King. Grand Rapids, MI: Eerdmans, 2001.

Harris, R. Laird, Gleason L. Archer, J. and Bruce K. Waltke, eds. Theological Wordbook of the Old Testament. 2 vols. Chicago, IL: Moody Publishers, 1980.

Hertzberg, Hans W. I \& II Samuel. OTL. Louisville, KY: Westminster John Knox Press, 1964.

Ho, Craig Y.S. "The Stories of the Family Troubles of Judah and David: A Study of their Literary Links.”Vetus Testamentum 49 (1999): 514-31.

Holloway, Steven. "Distaff, Crutch or Chain Gang: The Curse of the House of Joab in 2 Samuel 3:29." Vetus Testamentum 37 (1987): 370-75. 
Johag, Ingeborg. "טنב - Terminus Technicus in Vertrags- und Bündnisformularen des Alten Orients und des Alten Testaments." Pages 3-23 in Bausteine Biblischer Theologie. Edited by H.-J. Fabry. BBB 50. Köln und Bonn: Peter Hanstein Verlag, 1977.

Jones, Alfred. Jones Dictionary of Old Testament Proper Names. Grand Rapids, MI: Kregel Publications, 1990.

Keys, Gillian. "The So-Called Succession Narrative: A Reappraisal of Leonard Rost's Interpretation of II Samuel 9-20 and I Kings 1-2.” PhD diss., Queen's University of Belfast, 1988.

Kim, Uriah. Identity and Loyalty in the David Story: A Postcolonial Reading. Sheffield: Sheffield Phoenix Press, 2008.

Kissling, Paul J. Genesis. CPNIVC. Joplin, MO: College Press Publication Co., 2009.

Kitchen, Kenneth. On the Reliability of the Old Testament. Grand Rapids, MI: Eerdmans, 2003.

Kleven, Terence J. "Hebrew Style and Narrative Sequence in II Samuel I-VII." PhD diss. Manchester University, 1990.

Layton, Scott. “A Chain Gang in 2 Samuel 3:29: A Rejoinder.” Vetus Testamentum 39 (1989): 81-86.

Leithart, Peter J. A Son to Me: An Exposition of 1 \& 2 Samuel. Moscow, ID: Canon Press, 2003.

Lemche, Niels P. "David's Rise.” Journal for the Study of the Old Testament 10 (1978): $2-25$.

Levenson, Jon D. “1 Samuel 25 as Literature and History.” Catholic Biblical Quarterly 40 (1978): 11-28.

Levenson, Jon D. Sinai and Zion: An Entry Into the Jewish Bible. Oak Grove, MN: Winston Press, 1985.

Levenson, Jon D., and Baruch Halpern. "The Political Import of David's Marriages." Journal of Biblical Literature 99 (1980): 507-18.

Linafelt, Tod, Claudia V. Camp, and Timothy Beal, eds. The Fate of King David: The Past and Present of a Biblical Icon. New York: T\&T Clark, 2010. 
Mabee, Charles. "David's Judicial Exoneration." Zeitschrift für die Altestamentliche Wissenschaft 92 (1980): 89-107.

Mathews, Kenneth A. Genesis 1-11:26. NAC 1A. Nashville, TN: B\&H Holman, 1996.

Matzal, Stefan C. “A Wordplay in 2 Samuel 4.” Vetus Testamentum 62 (2012), 462-464.

McCarter, P. Kyle. “The Apology of David.” Journal of Biblical Literature 99 (1980): 489-504.

McCarter, P. Kyle. I Samuel: A New Translation with Introduction and Commentary. AB 8; Garden City, NY: Doubleday, 1980.

McCarter, P. Kyle. II Samuel: A New Translation with Introduction and Commentary. AB 9. Garden City, NY: Doubleday, 1984.

McKenzie, Steven L. King David: A Biography. Oxford: Oxford University Press, 2000.

McMurray, Heather. “Ahinoam.” NIDB 1:88.

McNaughton, Daniel L. "A Comparative Analysis of Three Versions of 2 Samuel 21:114.” PhD diss., University of St. Michael's College, 2000.

Mellish, Kevin. $1 \& 2$ Samuel: A Commentary in the Wesleyan Tradition. NBB. Kansas City, MO: Beacon Hill Press, 2012.

Mildenberger, Friedrich. "Die vordeuteronomische Saul-Davidüberlieferung." Diss., Eberhard Karls Universität Tübingen, 1962.

Miscall, Peter D. "Introduction to Narrative Literature." Pages 539-552 in vol. 2 of The New Interpreter's Bible. Edited by Leander E. Keck. Nashville, TN: Abingdon Press, 1998.

Morrison, Craig. 2 Samuel. BerO. Collegeville, MN: Liturgical Press, 2013.

Murray, Donald F. Divine Prerogative and Royal Pretension: Pragmatics, Poetics, and Polemics in a Narrative Sequence about David (2 Samuel 5.17-7.29). Sheffield: Sheffield Academic Press, 1998.

Myers, Jacob. 2 Chronicles. AB 13. Garden City, NY: Doubleday, 1965.

Newkirk, Matthew. Just Deceivers: An Exploration of the Motif of Deception in the Books of Samuel. Eugene, OR: Pickwick Publications, 1995

Noll, Kurt L. The Faces of David. Sheffield: Sheffield Academic Press, 1997. 
Noth, Martin. History of Israel. London: SCM Press, 1983.

Nübel, Hans-Ulrich. Davids Aufstieg in der frühen Israelitischen Geschichtsschreibung. Diss., Friedrich-Wilhelms-Universität, 1959.

Pennoyer, Raymond P. "Solomonic Apologetic: Text and Redaction in the Succession Narrative with Special Attention to the So-called 'Miscellanies' in 3 Reigns 2." PhD diss., Johns Hopkins University, 1993.

Polzin, Robert. David and the Deuteronomist: A Literary Study of the Deutonomistic History, Part Three, 2 Samuel. Bloomington, IN: Indiana University Press, 1993.

Robinson, Gnana. Let Us Be Like the Nations: A Commentary on 1 \& 2 Samuel. ITC. Grand Rapids, MI: Eerdmans, 1993.

Rudolph, Wilhelm. Chronikbücher. Tübingen: Verlag J.C.B. Mohr Paul Siebeck, 1955.

Sacon, Kiyoshi K. "A Study of the Literary Structure of the 'Succession Narrative."” Pages 27-54 in Studies in the Period of David and Solomon and Other Essays: Papers read at the International Symposium for Biblical Studies, Tokyo, 5-7 December, 1979. Edited by Tomoo Ishida. Winona Lake, IN: Eisenbrauns, 1982.

Sailhamer, John H. The Pentateuch as Narrative. Grand Rapids, MI: Zondervan, 1992.

Seiler, Stefan. Die Geschichte von der Thronfolge Davids (2 Sam 9-20; 1 Kön 1-2): Untersuchungen zur Literarkritik. Berlin; New York: de Gruyter, 1998.

Shemesh, Yael. "Madua harag Yoab et Abner." Beit Mikra 173 (2003): 144-53.

Short, J. Randall The Surprising Election and Confirmation of King David. Cambridge, MA: Harvard University Press, 2010.

Smith, Henry P. A Critical and Exegetical Commentary on the Books of Samuel. ICC 7. Edinburgh, Scotland: T\&T Clark, 1898.

Staats, Carl Gary. "Aspects of Negative Role Modeling in the David/Bathsheba Story and its Sequel." PhD diss., New York University, 1989.

Steinmann, Andrew E. 2 Samuel. ConcC. St. Louis, MO: Concordia Publishing House, 2017.

Sternberg, Meir. The Poetics of Biblical Narrative: Ideological Literature and the Drama of Reading. Bloomington, IN: Indiana University Press, 1987. 
Steussy, Martin J., David: Biblical Portraits of Power. Columbia, SC: University of South Carolina Press, 1999.

Stolz, Fritz. Das erste und zweite Buch Samuel. ZBK 9. Zürich: Theologischer Verlag, 1981.

Tsevat, Matitiahu. "Ishbosheth and Congeners: The Names and their Study." Hebrew Union College Annual 46 (1975): 71-87.

Tsevat, Matitiahu. "Marriage and Monarchial Legitimacy in Ugarit and Israel." Journal of Semitic Studies 3 (1958): 237-43

Tushima, Cephas T.A. The Fate of Saul's Progeny in the Reign of David. Eugene, OR: Pickwick Publications, 2011.

Vanderkam, James. "Davidic Complicity in the Deaths of Abner and Eshbaal: A Historic and Redactional Study." Journal of Biblical Literature 99 (1980): 521-39.

Van Gemeren, Willem A., ed. New International Dictionary of Old Testament Theology and Exegesis. 5 vols. Grand Rapids, MI: Zondervan, 1997.

Vannoy, J. Robert. 1-2 Samuel. CBibC 4a. Carol Stream, IL: Tyndale House Publishers, 2009.

Van Seters, John. The Biblical Saga of King David. Winona Lake, IN: Eisenbrauns, 2009.

Van Wijk-Bos, Johanna W. H. Reading Samuel: A Literary and Theological Commentary. Macon, GA: Smyth \& Helwys Publishing, 2011.

Van Wolde, Ellen. "A Leader Led by a Lady: David and Abigail in 1 Samuel 25." Zeitschrift für die Altestamentliche Wissenschaft 114 (2002): 365-66.

Veijola, Timo. David: Gesammelte Studien zu den Davidüberlieferungen des Alten Testaments. Helsinki: Finnische Exegetische Gesellschaft, 1990.

Veijola, Timo. Die ewige Dynastie: David und die Entstehung seiner Dynastie nach der deuteronomistischen Darstellung. Helsinki: Suomalainen Tiedeakatemia, 1975.

Vom Orde, Klaus. Das zweite Buch Samuel. WS. Wuppertal, Germany: R. Brockhaus Verlag, 2002.

Walsh, Jerome. Old Testament Narrative: A Guide to Interpretation. Louisville, KY: Westminster John Knox Press, 2009. 
Ward, Roger L. "The Story of David's Rise: A Tradicio-Historical Study of I Samuel XVI 14-II Samuel V.” PhD diss., Vanderbilt University, 1967

Weiser, Artur. "Die Legitimation des Königs David: Zur Eigenart und Entstehung der sogenannten Geschichte von David's Aufstieg." Vetus Testamentum 16 (1966): 325-54.

Wenham, Gordon J. "Sanctuary Symbolism in the Garden of Eden Story." Pages 399-404 in "I Studied Inscriptions from before the Flood": Ancient Near Eastern, Literary, and Linguistic Approaches to Genesis 1-11. Edited by Richard S. Hess and David T. Tsumura. Winona Lake, IN: Eisenbrauns, 1994.

Whitelam, Keith W. "The Defence of David." Journal for the Study of the Old Testament 29 (1984): 61-87.

Wolf, Horace J. “Chileab.” ISBE 1:611.

Yarchin, William. "The Warrior and the Shepherd: A Composition Analysis of 2 Samuel 21-24." PhD diss., The Claremont Graduate School, 1993.

Youngblood, Ronald F. “1 \& 2 Samuel.” Pages 21-614 in vol. 3 of The Expositor's Bible Commentary. Edited by Tremper Longman III and David E. Garland. Grand Rapids, MI: Zondervan, 2010. 
VITA

Education
Aug 10 - present
Doctor of Philosophy, Seventh-day Adventist Theological Seminary, Andrews University
Aug 08 - Aug 10
Master of Arts in Religion, Seventh-day Adventist Theological Seminary, Andrews University
Sep 00 - May 05
Bachelor of Theology, Seminar Schloss Bogenhofen, Austria

Work Experience
Jan 17 - present
Theologian, Stimme der Hoffnung e.V., Germany
Oct 16 - Dec $17 \quad$ Clerk, Stimme der Hoffnung e.V., Germany
Jan 11 - May 14 Adjunct Professor, Seventh-day Adventist Theological Seminary, Andrews University
Oct 05 - Aug 08 Assistant Pastor, Austrian Union, Austria 
